
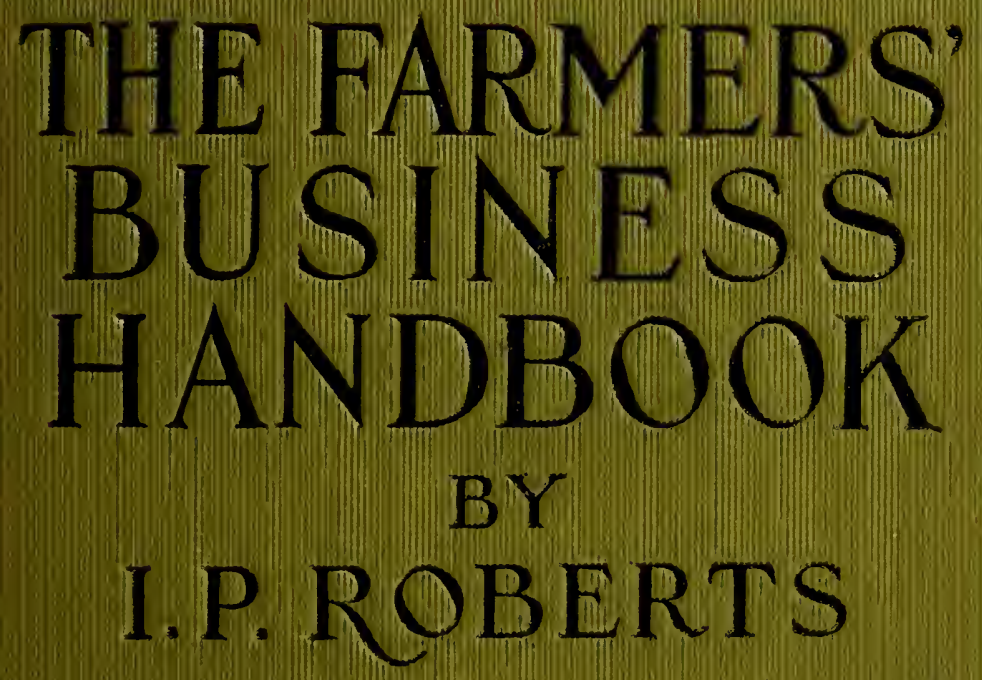

The Rural Science Series L.H.Bailey Editor 


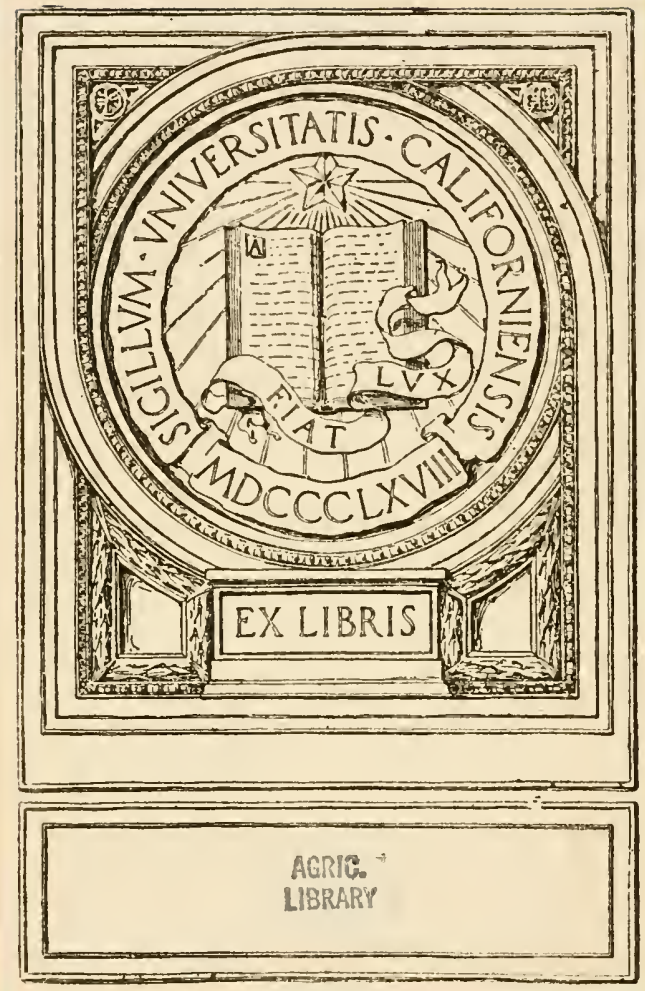








\section{OIf 12 ural beience serieg}

EDited BT L. H. Bailet

\section{THE FARMER'S BUSINESS HANDBOOK}




\section{The lâural Ściente Serieg}

The SoIL.

The Spraying of Plants.

Milk and its Products.

The Fertility of the Land.

The Principles of Fruit-Growing.

Bush-Fruits.

Fertilizers.

The Principles of Agriculture.

IRRIGATION AND Drainage.

The Farmstead.

Reral Wealth and Welfare.

The Principles of Vegetarle-Gardening.

FARM POULtry.

The Feeding of Animals. 


\title{
THE FARMER'S BUSINESS HANDBOOK
}

\author{
A MANUAL OF \\ SIMPLE FARII ACCOUNTS AND OF \\ BRIEF ADVICE ON RURAL LAW
}

BY

\section{ISAAC PHILLIPS ROBERTS}

DIRICTOR OF THE COLLEGE OF AGRICELTERE AND PBOFISSOR OT AGRICULTCRE IN CORNELL CNIVERSITY

ATTHOR OF "FERTILITY OF THE LAND" AND "THE FABYSTEAD"

SIXTH EDDTION .

Pem 侽ork

THE MACMILLAN COMPANY

LONDON: MACMILLAY \& CO., LTD.

1913

$\Delta l l$ rights reserved 


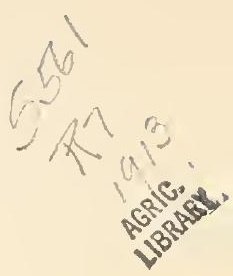

Coptright, 1903

BY THE MACMILLAN COMPANY

Set up and electrotyped, March, 1903

Reprinted, June, 1908, January, 1909

June, 1911, June, August, 1913

\section{Alout flowant Fress}

J. Horace McFarland Company

Harrisburg, Pennsylvania 


\section{PREFACE}

IT is said that the farmer should be a scientific man. I like to think of him, also, as a business man. In fact, unless he is a good business man he is not a good farmer. He must not only grow crops, but he must buy and sell, and must be a man among men. Yet, how few of our farmers ever keep a consecutive account of their farm operations, and how seldom can they tell how much the year is worth to them!

This little book has grown out of many years' teaching farm boys. It is intended to meet the condition of the average farmer; those that conduct large enterprises will have a professional accountant, and, perhaps, a legal adviser, and will not need such an elementary treatise as this.

That part of this work which treats of Rural Law is written by Herbert Delavan Mason, of the New York State Bar. It is hoped that this treatment of many of the commoner and more usual aspects of the law applicable to rural matters will frequently be found of assistance 
to the reader in determining and guarding his rights; but it is not of course intended that it shall do away with the necessity of counseling with the family lawyer on all important matters. Indeed, one of the chief objects of the article is to warn its readers of the very great necessity of freely seeking such counsel. It will be noticed that many of the statements of the text are expressly limited in their application to certain localities; and in all cases the reader should determine, before he undertakes any important course of action, what are the statutes and customs of his own state and locality.

If Part $I$ is used as a text-book in schools and colleges, the instructor should add, omit or change a few items in the Blotter, so that neither the Trial Balance, nor the Gain and Loss statement, will be identical with those on pages 71 and 76. Each transaction noted in the Blotter should be stated clearly by the teacher something as follows: "On April 25, four tons of hay were taken from the field and placed in the cattle barn." (See page 49.) The pupil should be asked to name the debtor and the creditor in this transaction. The answer should be something as follows:

"Live Stock Dr.

Hay Field Cr." 
When the pupils have written in their Blotters the accounts as above, the teacher should give details of the transaction: "four tons of clover hay at seven doliars per ton." In like manner proceed with all other accounts in the Blotter.

The Inventories may also be modified, in order to prevent the pupils from making a mere coly of the printed pages. If time permits, it is always best to have each item read and discussed before it is recorded. After the Inventories, Work Reports and Blotter are completed, the pupils should be given one or two weeks in which to post the items to the Ledger, distribute and enter Tool Account, page 51, make out Trial Balance, page 71, enter the Inventories at the end of the year, page 72, and make a statement of Gain and Loss by both methods, pages 73 and 76 .

\section{P. ROBERTS.}

Cornell Ciniversity, Ithaca, N. $\mathbf{Y}$.

February 28, 1903 



\section{CONTENTS}

\section{PART I-FARM ACCOUNTS}

\section{CHAPTER I}

PAG:

Why Accounts Should BE KePT .......... 1-21

CHAPTER II

THE KINDS OF Accounts . . . . . . . . . . 22-41

CHAPTER III

THI BLOTTER . . . . . . . . . . 42-52

CHAPTER IV

The Ledger. . . . . . . . . . . . . . . . . 53-69

CHAPTER V

The Trial Balance . . . . . . . . . . 70-81

CHAPTER VI

Accodnts with Particular fields and Crops . . . 82-100 (ix) 
CHAPTER VII

Accounts with ANMALS. . . . . . . . . 101-142

Milk Acconnts . . . . . . . . . . 101

Poultry Accounts . . . . . . . . . . . . 110

Accounts with Rations of Farm Animsls . . . . . 116

CHAPTER VIII

ACOOdNTS With the Farm Household . . . . . . 143-152

\section{PART II-RORAL LAW}

By H. D. MASON

\section{CHAPTER IX}

Property, Deeds and Conveyances . . . . . . . 153-169

I. Real and Personal Property, and Distinctions Between Them . . . . . . . . . . . 153

II. Deeds . . . . . . . . . . . . . 156

III. Abstracts of Title . . . . . . . . . 159

IV. Leases . . . . . . . . . . . . . . 163

V. Tenant's Right to Remove Crops at Fnd of Term . 167

CHAPTER $\mathrm{X}$

Trespass and Water Rights .......... 170-173

I. Trespass ................. 170

II. Animals ................ 170

III. Water Rights ............. 171

IV. Drainage . . . . . . . . . . 173 
HIGHWAYS AND ROADSIDES

I. Use of Roadsides . . . . . . . . . . 174

II. Impsssable Highways ........... 175

III. Laws Affecting Travel on Highways . . . . . 176

!V. Sido Paths . . . . . . . . . . . . . . . . 180

V. Watering Troughs and Shade Trees ..... 181

VI. Guide Boards . . . . . . . . . . . . 182

VII. Weeds Along Highways .......... 182

\section{CHAPTER XII}

Legal Fences . . . . . . . . . . . 184-192

I. What a Legal Fence Is ........... . 184

II. Line Fences. . . . . . . . . . . . . . . 185

III. Road Fences. . . . . . . . . . . . . . . . . 190

IV. Incorrect Line Fences Made Legal Boundary by Lapse of Time . . . . . . . . . . . . . . 191

CHAPTER XIII

Contracts . . . . . . . . . . . . . 193-207

I. In General . . . . . . . . . . . . . . 193

II. Warranties Upon Sale of Horses or Other Animals . 205

\section{CHAPTER XIV}

Mutdal Liabilities of Emploter and Emplotee, Buter AND SELLER............ . 208-213

I. Liability of Employer for Acts of Employees . . . 208

II. Mechanics' Liens . . . . . . . . . . . . . . 210

III. Artísans' Liens . . . . . . . . . . . . . . 212

IV. Liens of Hotel, Boarding-House, Lodging-House and Livery Keepers . . . . . . . . 213 


\section{CHAPTER XV}

Notes, Due-Bills, Chattel Mortgages and Bills of

SALE . . . . . . . . . . 214-227

I. Promissory Notes ............ 214

II. Due-Bills, Orders, Receipts ........ 224

III. Chattel Mortgages . . . . . . . . . 225

IV. Bills of Sale............. 227

\section{CHAPTER XVI}

Gifts, Wills, Advances, Usury and Taxes . . . 228-240

I. Gifts................. . . . . . 228

II. Wills . . . . . . . . . . . . 231

III. Advaneing Money or Property to One's Children . 236

IV. Usury . . . . . . . . . . . . . . 237

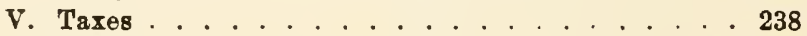

VI. Real Property Purchased with Pension Money Exempt from Taxation . . . . . . . . 239

\section{CHAPTER XVII}

Powers of Attorney, Afridayits, Legal Tenders . 241-244

I. Powers of Attorney . . . . . . . . . . . 241

II. Affidavits . . . . . . . . . . . 242

III. Legal Tenders.............. 243

\section{PART III-INVENTORIES FROM}

THE CENSOS-245-281

I. Agricultural Population. . . . . . . . 248

II. Farm Acreage . . . . . . . . . 250

III. Rented Farms ............... 251 
IV. Acreage of Rented Farms . . . . . . . 253

V. Value of Rented Farms . . . . . . . 255

VI. Owners of Rented Farms. . . . . . . . 257

VII. Animals in Barns and Enclosures . . . . . 259

VIII. Number of Domestic Animals . . . . . . 261

IX. Number of Neat Cattle . . . . . . . . . 263

X. Number of Horses, etc. . . . . . . . . 265

XI. Number of Sheep, Swine and Goats . . . . . 267

XII. Number and Value of Neat Cattle . . . . . . 269

XIII. Number and Value of Sheep and Swine . . . . 271

XIV. Arerage Value of Neat Cattle ....... . 273

XV. Average Value of Horses and Mules . . . . . . 275

XVI. Average Value of Sheep, Swine and Goats . . . 277

XVII. Dairy Cows and Dairy Products .... . . . . 279

XVIII. Counties Having $\$ 1,000,000$ and Lpwards of Dairy Products . . . . . . . . . . . 281

XIX. The Importance of Agriculture as a Source of National Wealth, as Exhibited by New York State, 1899 . . . . . . . . . . 282

XX. Values of Farm Property and Farm Products . . . 283

XXI. Relative Agricultural Ranks of Various States . . 284

XXII. Relative Number of Persons Engaged in Agriculture . . . . . . . . . . . . . . 291

XXIII. Agricultural Education. . . . . . . . 292 



\section{THE FARMER'S BUSINESS HANDBOOK}

\section{PART I-FARM ACCOUNTS}

\section{CHAPTER I}

\section{WHY ACCOUNTS SHOULD BE KEPT}

Most persons not engaged in regular mercantile pursuits think it mnecessary to keep accurate account of the little business they transact, but trust to memory, or to brief memoranda of the larger operations. Usually the small farmer keeps no account whatever of his dealings with other men, or with his fields and live stock. If he does jot down memoranda of his dealings with his neighbor's, he is likely to carry his pass-book in the side pocket of his "every-day" coat, which, after being thrown on the fence or on a load of hay, parts company, in some very mysterious way, with the precious little book. When the owner of the coat goes on the witness-stand he must trust solely to memory. Now and then a farmer of unusual ability and enterprise makes a sincere attempt to keep account of the larger transactions 
of the farm, but unless he employs an accountant there is likely to be no system, nor continuity, nor intelligible result. Even if an accountant is employed, the methods are generally those used in ordinary mercantile bookkeeping, which, not being adapted to farm accounts, may require two Philadelphia lawyers to interpret.

In any case, farm accounts, if useful, are especially difficult to keep. This is not because the principles of bookkeeping cannot be made to serve as well in farm operations as in mercantile pursuits, but because many of the entries must be estimates rather than statements of actual transactions.

Most men, farmers included, lack or have lost the habit of study. It is an age of haste, much reading and poor mental digestion. The demands of modern life are so numerous, varied and exacting that the tendency is inevitably to learn a little of many things instead of much of a few things. Few people master perfectly the details of their profession before relegating them to subordinates. The farmer, like other business men, must make himself familiar with every detail before he is fitted to direct the labor of others successfully. $\mathrm{He}$ should substitute knowledge for random guesses; he should know his real financial condition. Mere estimates of worth and profit seldom prove to be correct. 
This little treatise is prepared for those who wish to know at the end of each year what are the assets, liabilities, net worth and profits, and also which crop and which group of animals give profit and which give loss. Only by keeping record of each cow can it be determined which ones are being kept at a profit and which at a loss. The lean kine may use up the profits of the fat kine. How many farmers can tell how much they were worth at the beginning of any given period, or can state what were the gains or losses of any year's operations? A man may be able to say that he started in business in 1860 with $\$ 1,000$ and that in 1890 , thirty years afterward, he was worth $\$ 15,000$; but he will have no exact knowledge as to whether he secured profits in producing wheat or wool, cotton or cattle, potatoes or poultry. He may have made $\$ 1,000$ in cattle in a single year, twice the yearly average profits, and may have lost $\$ 600$ in wheat or wool; but in the absence of accounts there is no way of determining where or how the gains were made or the losses incurred.

Few farmers, or indeed, small dealers or merchants in towns, have ever taken stock or inventoried their belongings. It is a surprising fact that while most business men are striving faithfully to secure a surplus, many at the end of the year never note the advance or deprecia- 
tion of their property; much less do they keep a record by which they may determine whether there were any losses or profits, and whence each arose.

Sir Henry Gilbert, of Rothamstead, England, an eminent investigator, when visiting the United States a few years ago, tried to find out by many inquiries in well-to-do families what proportion of the expense of an American household was incurred for meats, for breadstuffs, for butter, for service, etc. $\mathrm{He}$ could not find a single householder who could give him information on these points. The American too often pays bills without inspection and does not even preselve the receipts. This busy, scientific worker could tell both the total and per capita expenditure of his household for butter, meats, bread, clothing, servants and other items. But he was unable to make any comparison between English and American huusehold expenses because he was unable to secure the detailed, or even the gross expenditure of persons in circumstances comparable with his own.

While traveling in England I noticed that even the third-class passengers with their harvesting implements, on the railways going to the country districts, carried little blank books in which they noted down their expenses. In America, it is not uncommon to find a professor or a 
learned institute lecturer who cannot keep his traveling expense account correctly for three days at a time.

I think there are two chief causes tending to produce financial carelessness in the United States: Children are rarely taught to render an account of expenditures at the end of the month. Although a little bookkeeping is taught in some schools, it is sometimes about as workable on a farm as an ox-cart would be on a railway. Again, in the last half century, life has been so much easier in America than in Europe-both necessities and comforts have been secured with so little effort-that it has not seemed worth while to note critically the outgo and the income. But these conditions are not likely to remain the same for another half century. The effort to curtail expenses is always difficult and unpleasant, but far more so if there are no itemized data which may help to indicate just where to begin or where curtailment would least affect comfort and pleasure. Most sane people are extremely unhappy when their outgo is equal to or exceeds the income. Some are really unhappy only when the bills come in; while others live in dread of petty debts scattered they know not where, and in amounts which have been forgotten, not knowing whence the next dun will come or how or when disgrace may fall upon them. 
How often I have seen a noble, industrious farmer marketing his chief money crop of the year, the wheat or the wool, or the fat live stock! With what honest pride he laid the check for several hundred dollars on the bank counter and then stuffed that "wad" of bills into his "side pocket!" Then with what a cheerful voice he asks at the desk of the grocer for the amount of his account! "Fifty-six dollars and seventy-two cents," the clerk responds. "There must be some mistake; it cannot be more than half that." The items are looked up, the charges are correct, the bill is paid. In a voice out of which some of the courage has gone, he asks for his account at the dry goods store. This is nearly one hundred dollars. He disputes the account, says he never had the goods, there is some mistake, they have been charging neighbors' purchases to his account; he takes an hour to inspect the items, pays the bill under protest, and, concluding that he has had enough unhappiness for one day, takes something to drink and lets the half dozen other fellows wait for their pay. For it will be some pleasure to carry even a small roll of bills for at least a few days in the year. But he has not learned his lesson, for he carries home no itemized bill for study; he keeps no account and hence he will never know what his real financial condition is. Because it is "too much 
trouble" to keep track of his business, he will go on having a few hours of happiness and many gloomy days; each year he will lose faith in himself, in his fellowmen and in his business.

\section{INVENTORY}

The simplest method of determining gains and losses is to take an inventory at some stated time each year. In many of the states, as New York, where the spring is really the beginning of the farm year and only a little grain and roughage ${ }^{1}$ will be on hand, the inventory would better be made either the first of April or May. It is assumed that any intelligent farmer, from such inventory, will be able to tell at least once a year the amount of bills receivable and bills payable, that is, how much is owing to him and how much he owes, and the amount of net assets of personal property.

It is surprising how much the judgment is developed in making a detailed list of one's belongings, with values attached. When the second inventory is made, at the end of the year, the breakage, losses and depreciation of some of the property will stand out in bold relief. It is said that one can winter a horse and

1 Roughage is any coarse feed, as hay, straw, corn-stalks, and the like. 
bring him through in good shape, ready for use, more certainly than he can a hand-rake. The need of careful driving may be emphasized by the inventory as it cannot be in any other way, when, becanse of careless driving and feeding, the horse valued at $\$ 150$ at the beginning of the year is worth but $\$ 75$ at the end of the year.

Every provident housewife should have a list of all the principal articles under her control, with date of purchase and cost. Whenever the cost price is not known, present estimated values should be affixed to the list. I know of one family that keeps such an inventory in a small tin-box, which is placed in another box buried in the ground near the house. In case of damage or loss by fire, such record is likely to be of great value, for the insurance companies require a specific statement in detail as to the character of each article and its value before adjusting a partial claim.

Recently, at a sale of household goods, the inventory was used as a basis for setting the prices of these articles. By this means a uniform average of 50 per cent was obtained for articles in good condition.

The following brief inventory of stock, tools, household goods, assets and liabilities will serve to show the simplest possible method of determi- 
ning gross gain or loss at the end of each year. Usually the inventory will be more extended than the one given. The household belongings are not given in detail here as it should be in practice, because they would take too much space.

\section{Inventory taken May 1, 1900, of the personal property of John Doe}

\section{TEAMS}

1 gray mare, Nell, 10 years old ............... \$100 00

1 gray horse, Jim, 12 years old ... .............. 8000

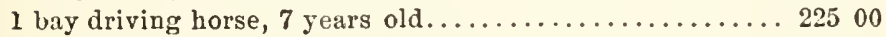

1 bay mare, Gip, 10 years old .................. 10000

2 sets double harness, at $\$ 20$ and $\$ 30 \ldots \ldots \ldots \ldots \ldots \ldots . \ldots 50 . \ldots \ldots$

4 horse pails.............................. 100

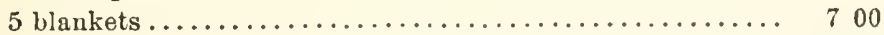

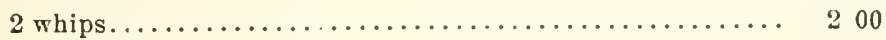

2 curry-combs, 2 brusbes..................... 300

1 set single harness ......................... 4000

2 tons horse hay, at $\$ 10$ per ton................... 2000

Total.............................\$628 00

\section{LIVE STOCK}

3 milch cows, Fan, May and Spot, at $\$ 40 \ldots \ldots \ldots \ldots \ldots \ldots 12000$

2 milch cows, Snip and Roan, at $\$ 35 \ldots \ldots \ldots \ldots \ldots . \ldots 700 . \ldots \ldots$

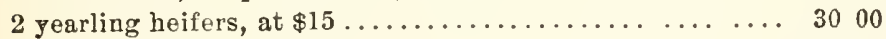

1 steer, 2 years old........................ 3500

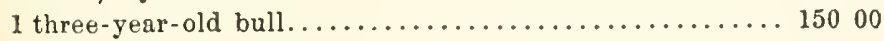

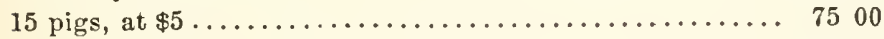

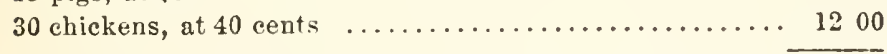

Total.......................................... 00 


\section{FARM TOOLS}

1 self-binder.............................\$125 00

1 mower................................. 8000

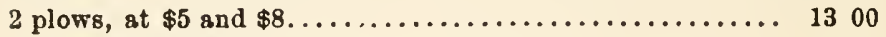

1 double barrow ........................... 1200

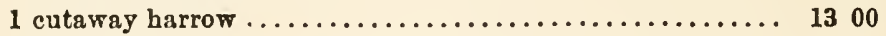

1 grain drill ............................. 5000

1 farm wagon, trees and yoke.................... 7500

1 light wagon............................ 30 00

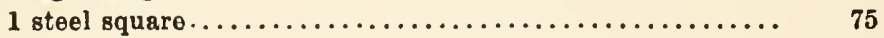

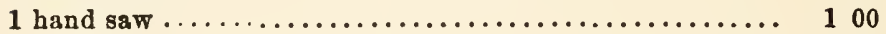

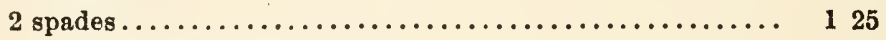

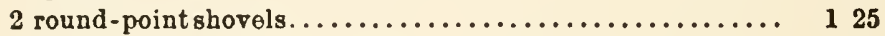

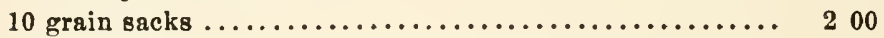

4 hay forks ............................... 300

2 four-tined forks......................... 125

Total.............................\$40850

\section{Farm Products}

420 bushels of wheat on hand unsold, at 75 cents.......\$315 00 Total..............................\$315 00

\section{Bills Receivable}

Note of James Burroughs on demand without interest . . . \$163 25 Note of John Price, 2 months, interest at 6 per cent...... 37600

Total $\$ 53925$

\section{BiLLS PaYABLE}

Store bill, C. Bessy.......................... \$76 00

Grocery bill, Henry Bell ..................... 3100

Total.............................. $\$ 10700$ 
Cash oN HaNd

In bank ..............................\$350 00

On person ................................ 2500

Total.............................\$375 00

\section{FARM HOUSEHOLD}

As per detsiled statement filed................\$625 00

Total...........................\$62500

\section{SUMMARY}

Teams.........................\$628 00

Live stock. ...................... 49200

Farm tools ..................... 40850

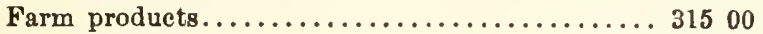

Bill receivable..................... 53925

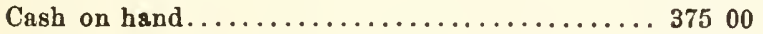

Farm household....................625 00

Less bills payable..................... 107 100

Net assets $. \ldots \ldots \ldots \ldots \ldots \ldots \ldots \ldots \ldots \ldots \ldots \ldots \ldots \ldots \ldots \ldots \ldots \ldots+27575$

\section{Real Estate}

Farm, including buildings and other betterments, 100 acres at $\$ 50$ per acre.....\$5,000 00

Mortgage $\$ 1,500$, and two months' accrued interest at 5 per cent, April 1, $1900 \ldots 1,51250$

Net value in excess of mortgage ..........\$3,487 50 Net personal property.................. 3,275 75 Total net assets April 1, $1900 \ldots \ldots \ldots \ldots . . . \$ 6,76325$

A summary of the financial conditions at the end of the year follows. The inventory at the 
end of the year should be made as at the beginning. In the text the values have been assumed since the method of taking the inventory in detail is shown on page 9. However, in practice, the details should be set forth clearly, and from them the summary which follows would be made. It should be noted that the values, as set down in the second summary below, have changed, some being larger and some smaller, but their totals exceed the values at the beginning of the year by $\$ 831.25$, which is profit.

\section{SUmmary April 1, 1901}

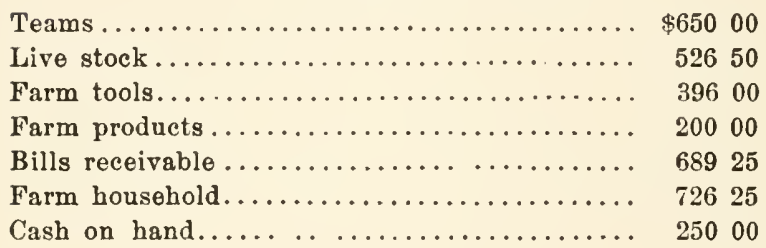

$\$ 3,43800$

Less bills payable...................... 2800

Net personal assets.................. $\$ 3,41000$

Value of farm...................\$5,000 00

Less balance of mortgage nnpaid ....... 81550

Net......................... \$4,184 50

Net value of all property.............\$7,594 50

Net value of property April 1, $1900 \ldots \ldots \ldots \ldots, 76325$

Gain ............................. \$831 25 
While these inventories and summaries made at the beginning and the end of the year are of great value, they do not show whence the profits were derived - that is, whether secured from teams, live stock or wheat field. In the next chapter forms are given for more detailed accounts, with the view of determining, so far as possible, the exact sources of all profits and losses.

There is one other factor to be considered the depreciation or increase in the value of the farm. In the above inventory, taken at the end of the year, this factor has not been noted, but it is not uncommon for the value of a farm to change somewhat even in a single year. There may have been a decrease not only in the selling price of the farm, but in its real value, as measured by the profits. But usually the fluctuations of farm values are not likely to be large in any one year. An increase in value may be due to some unusual betterment, as the erecting of a building or the thorough draining of a wet field; or an account may have to be taken of ordinary depreciation of buildings, fences, etc., or the farm, as a whole, may be slightly less or slightly more fertile than at the beginning of the year. All of this must be left to the judgment of the owner, but such judgment should be conservative.

It is bad to deceive one's neighbor, but it is infinitely more harmful to deceive oneself. In 
the former case, the deception is likely to be corrected in time, but in the latter case the deceiver and the deceived are the same person and there is no outside party to correct the error.

It may be said that the bills receivable, $\$ 689.25$, and the cash, $\$ 250$, together, are more than equal to the unpaid mortgage, and that it might have been better financiering to have paid off all the mortgage, although the working capital would have been reduced to $\$ 123.75$. Just here, however, is where most farmers make their mistake. They provide too little working capital and are thus debarred from taking advantage of "selling money dear," or of purchasing something cheaply which may be turned into more money later at a profit. It should be said, however, that if $\mathbf{a}$ man has little business ability he would better "keep near shore" - that is, pay off the mortgage and carry on a smaller and safer, though less profitable, business.

It will be noticed that the financial condition of the farmer whose business has been set forth briefly is most excellent. The mortgage, so far from being a dangerous incubus, is a positive stimulant to intellectual effort. Most eminent financiers secure profits by the judicious use of other people's money. As the secretary of a flourishing western building and loan association puts it, "We buy money (borrow it) at five per 
cent and sell it (lend it) at ten per cent." If a farmer has his business well in hand, and has placed the mortgage as part of the purchase price of his land, it frequently becomes a blessing in disguise. It is easily proved that a moderate mortgage may sometimes be a positive help towards prosperity. The conditions we are considering are somewhat similar to those of most merchants in the cities, who rent the buildings in which the business is done instead of owning them, in order to have all their funds available for working capital. It will be noticed that John Doe had, at the beginning of business, a good working capital, $\$ 315$ worth of wheat, a demand note of $\$ 163.25$, and a note of $\$ 376$. His bills payable amount to $\$ 107$, but when these are liquidated he will have $\$ 268$ cash and $\$ 854.25$ of quickly available products and bills receivable.

In a city of twelve thousand inhabitants it was found that about nine-tenths of the chief business enterprises were conducted in rented quarters. Why may not the farmer find relief from annoying floating indebtedness by renting the plant (farm), thereby securing an abundant working capital which gives opportunity to buy at the lowest cash price and to sell when prices have advanced? The unwise man in haste to get rich would have paid out the larger part of his working capital on the mortgage to save a 
little interest and then have required the tradesmen to carry him for a year or more, deceiving himself in the belief that he had really saved his interest and indirectly gotten it out of the merchants. But the merchant always knows the difference between a cash and a trust customer who pays when he gets ready, and more than makes up the interest in higher prices, or poorer quality of goods. To pay for everything when delivered is to secure sound sleep and often from 10 to 15 per cent saving on purchases. Then, too, a man always walks more erect when his heart beats against a roll of Uncle Sam's I O U's, be it ever so small, than when he finds only keys, a pocket-knife and unpaid bills when his hand goes down in his pocket. There are two kinds of dangerous debts: those incurred for improvident living and running expenses of the farm; and debts too large to be justified by the man's business or by his experience and business ability.

\footnotetext{
"Little boats should keep near shore, Larger ones may venture more."
}

There are ten-acre, forty-acre, one-hundred-acre and five-hundred-acre farmers. The man is always the greatest factor in any enterprise.

In many cases the farmer would better not own the land he tills. He might properly adopt 
the practice of most merchants and use all funds as working capital, which may then be turned over more than once a year, leaving the capitalist, who does not care to carry on general business, to own and lease the real estate. In many cases it is far better to lease the farm than to own it encumbered with a mortgage approaching its value. If too large a proportion of the funds have been invested in realty, business operations may be seriously crippled.

Let us return to the inventory. We must now imagine that a second year has passed, that the wheat carried over has been sold and the new crop also, and that there has been a steady income from small enterprises, such as fruit, eggs, milk or its products. Let us imagine, also, that one or more horses or cows have been bought or sold, calves and colts reared, some of the farm tools worn out or lost, and new ones purchased. Another inventory at the end of the second year will be necessary which may be quite different from those which have preceded. It will not be necessary to go into detailed discussion of this short method of determining the single year's gain or loss.

"Is it anybody's business what a body's business is?" It may not be, but the wife and the older children should know-have a right to know-the result of the family labors. If the 
business is not prospering they should be acquainted with the fact in order to assist in discovering the cause or causes of the embarrassment. If economies and sacrifices must be made, they are made the easier if the reasons for them are fully understood. The uninformed wife or son may think father is stingy, or even "mean," but when they come to know the facts their relations to each other are not only changed. but they are willing to assist cheerfully in carrying the burden. It not infrequently happens that the wife is the best financier in the "company." In some cases, even, the older children first discover the leaks and learn ho.v to stop them. In any case, the wife and children have a right to know whether the business is prospering. They have helped to produce such prosperity and therefore they have a right to share in the happiness that it brings. The man, the woman and the larger children are all partners in the business, and while the man may be the active business manager the other parties have a moral, if not a legal right, to know, at least once a year, the conditions of the business, the profits or losses and the character of all investments. Therefore, the father is in duty bound to prepare a yearly statement, similar to the above, that the business of the firm may be thoroughly and intelligently discussed before a new year of operations 
is begun. In the business world this is always done. Can the farmer, whose profits are often small, afford to ignore the wise usages of all mercantile enterprises?

Are the gains as set forth at the end of the year satisfactory? This farmer has provided home employment for himself and family at fair wages, a moderate interest on all his property, including household goods and a fair profit in addition. If he had placed the money, $\$ 6,138.25$ (less household goods) at interest, gone to town, rented a house, secured work as best he could, and lived out of the grocery, would he have improved his condition financially or otherwise?

Most men are mentally lazy; most men are not physically lazy. Ten men can be secured to cast up banks of earth rapidly and correctly where one man can be secured who can cast up columns of figures rapidly and correctly. In country and city alike muscle is cheap and abundant; trained intellect is scarce and dear. Of course, half-trained intellectual workers are so abundant that it is a wonder where they all come from. It is a little depressing to feel, as these lines are being written, when the mercury is fluctuating around ninety degrees, that not one in ten who reads these lines will make persistent and intelligent effort to find out where he stands financially with the world, or what branch or branches of his business are 
producing profit, or what activities result in loss. There is one consolation or, rather, one fact,most men are financially careless; this robs criticism of its personal character. Too little has yet been done in the schools toward giving thorough instruction in accounts. True, an attempt to teach "bookkeeping," with its manifold quirks, may be made for one or two terms, but the subject is rarely mastered, is seldom real, and often is not adapted to the age and conditions of the pupil. Matter and method are likely to be rigid and hard. If the pupils were set to keeping accounts with the family receipts and expenditures a working knowledge of accounts would be gained, and the parents as well as the pupils would be benefited. Often an attempt is made to teach lads twelve to fifteen years of age all the forms and intricacies of commercial bookkeeping, which can be fully mastered only after years of practice in large commercial houses. In all other studies we commence with the simple and proceed slowly to the complex. In bookkeeping the lad is often drowned, suffocated in complexities, and if, by chance, he is ever resuscitated, he has forgotten which is credit and which is debit, or the meaning of bills payable and bills receivable, and, if called on to give a receipt, would word it as the man did in the story, 
"I've got the money. Yours truly,

Oliver Ditson."

Reared as he has been, the furmer is to be pitied, not blamed. Until more rational methods of teaching practical accounts are employed, the majority of the people will live on in the old-fashioned happy-go-lucky way. Happily, there are some young, progressive farmers who have the courage to attempt difficult problems and the desire to discover the profitable and unprofitable branches of their business. They may not have time or opportunity to keep a complete and detailed account of all transactions, but are still desirous of learning whence arise the profits and losses. Usually both profits and losses are present. One cow in a herd is producing a profit of twenty cents per day, another in the same herd is kept at a loss of ten cents per day. There may be a fair profit in the corn field and a loss in the wheat field. If the farmer can be persuaded that, by the expenditure of a little extra mental effort, he can discover these facts, we shall get him interested in the profits and losses of his business enough to adopt at least some method of keeping brief accounts, which, if continued, will lead naturaliy to keeping the fuller detailed accounts, as outlined in the following chapter. 


\section{CHAPTER II}

\section{THE KINDS OF ACCOUNTS}

The method of determining gain or loss outlined in Chapter I, while useful, is not full enough to reveal just where the gains or losses are made. The live stock may have been kept at a loss, while the growing of wheat resulted in satisfactory gain, or the live stock may have been kept at a profit while the wheat was grown at a loss. If the farmer is disposed to study his business critically, accounts must be kept somewhat in detail, and these will require some time, care and judgment. He who is willing to guess at the profits or losses of the various subdivisions of his business would better not undertake the keeping of a more detailed account than has already been outlined. But he who wishes to improve his methods and judgment, who wishes to master his business and not let it master him, would do well not simply to read, but to study carefully what follows.

The system given on the following pages is known as double-entry (p. 28). To get a clearer idea of the subject it is best to have in mind a few 
definitions and principles which apply to any kind of accounts, whether farmers' or merchants'.

Accounts are condensed records of business transactions.

Bookleeping is the art or practice of writing accounts methodically in books.

Kinds of accounts.-There are three kinds of accounts :

\author{
PROPERTY ACCOUNTS. \\ PERSONAL ACCOUN'TS. \\ INCIDENTAL ACCOUNTS.
}

These three kinds are the only ones needed for any business, no matter how large or how complicated its transactions. All three are needed in keeping a complete record of farm operations.

Property accounts. - Usually a farmer will keep an account with each kind of property. The simplest form of a property account is an account with property in money, or a Cash Account. The following is an illustration of a farmer's cash account, starting from the inventory given on page 9 :

\title{
Simple Cash Account
}

\begin{tabular}{|c|c|c|c|c|c|}
\hline $\begin{array}{l}\text { Apr. } 1 \\
\text { “ } 14 \\
\text { " } 14\end{array}$ & $\begin{array}{l}\text { Cash on hand and in } \\
\text { bank............. } \\
\text { Received from Rice's } \\
\text { note and interest.. } \\
\text { Received from apples } \\
\text { sold........................ }\end{array}$ & $\left|\begin{array}{rr}\$ 375 & 00 \\
378 & 40 \\
5 & 40\end{array}\right|$ & \begin{tabular}{|cr} 
Apr. & 3 \\
$\because$ & 7 \\
“ & 14 \\
& \\
“ & 16 \\
“ & 16 \\
“ & 16
\end{tabular} & 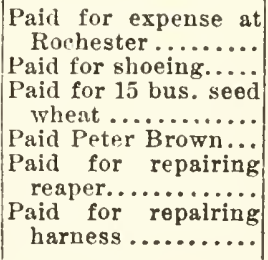 & $\begin{array}{rl}\$ 6 & 75 \\
8 & 25 \\
& \\
15 & 00 \\
10 & 00 \\
4 & 29 \\
3 & 68\end{array}$ \\
\hline
\end{tabular}


In the illustration, it will be noticed that there are two sides to the account; the left hand or debit side and the right hand or credit side. Note that

Whenever the farmer received money he wrote the amount on the left or debit side.
Whenever the farmer paid money he wrote the amount on the right or credit side.

If we deduct the cash paid from the cash received, we will have the amount of cash on hand; and if the amount is not the same as the actual amount of cash we at once know that an error has been made in our account. The difference between the two sides of an account is called the Balance, because it is the amount required to make the two sides equal. At regular intervals the two sides of every account should be added, balanced and a new account opened. Ideally, the cash should be counted at the close of each day's business and the amount on hand entered on the credit side. However, when the transactions are few, the cash account might be balanced weekly. The "balance" should be written in red ink (shown here in heavier type) to show that it does not represent an actual transaction and that it is to be the first entry in the new account on the opposite side. The balanced footings are ruled in red ink (shown here in dotted lines). A balanced cash account, with a new account opened, appears as follows: 
Balanced Cash Account, and a New Account Opened

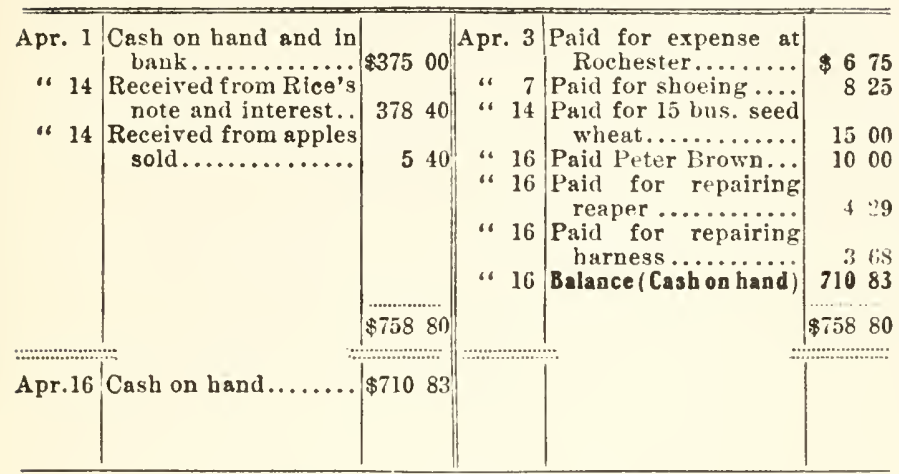

Accounts with all other kinds of property, whether wheat, horses or apples, are kept just as the cash account is, and

When the farmer buys property he writes the value of the property on the left or debit side.
When the farmer sells property he writes the value of the property on the right or credit side.

Most kinds of property other than cash are handled with either profit or loss. In order to find the amount of profit or loss the farmer must first, before closing the account, find out the value of the property on hand and add this amount to the eredit side of the account, and then balance the account. If the balance appears on the debit side it shows that a profit was made on the transaction; if the balance is on the credit side the transaction was a loss. 
Suppose the farmer is growing wheat and wants to know whether he is making or losing. His account with property in the form of wheat is as follows:

\section{Wheat Account (1900 Crop)}

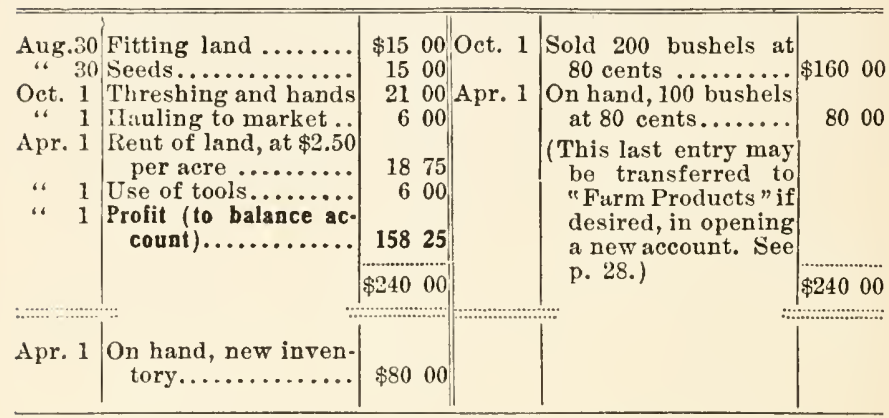

Personal accounts are kept with the men or firms (that is, with persons) with whom the farmer deals. When accurately kept, they show exactly what he owes and what is due him from others. A personal account appears as follows:

\section{JoHN SMITH}

\begin{tabular}{|c|c|c|c|c|c|}
\hline Apr. 4 & $\begin{array}{l}10 \text { bus. wheat } @ 60 \text { c. } \\
\text { To cash............ }\end{array}$ & $\begin{array}{rr}\$ 6 & 00 \\
20 & 00\end{array}$ & Apr.12 & $\left\{\begin{array}{l}1 \text { yearling calf....... } \\
254 \text { hours, at } 121 / 9 \mathrm{c} .\end{array}\right.$ & $\begin{array}{rr}\$ 20 & 00 \\
31 & 75\end{array}$ \\
\hline
\end{tabular}

In other words,

When the farmer sold John Smith goods or paid him cash, the farmer wrote the amount on the left or debit side of the account.
When John Smith worked for the farmer or when the farmer bought goods from him, the farmer wrote the amount on the credit side. 
If both sides of this account were added, it it would be seen that the entries on the right or credit side amount to $\$ 25.75$ more than the entries on the left or debit side. The balance, then, of $\$ 25.75$ is the amount the farmer owes John Smith. If the debit entries were more than the eredit entries it would show that John Smith owed the farmer.

Personal accounts should be kept with each person or firm with whom the farmer deals.

When the farmer sells his wheat there must be a buyer. There cannot be a sale when no one will buy. When the farmer buys 100 pounds of sugar, the sugar is taken from the merchant's property and added to the farmer's property. When the man and team spend several days fitting land for wheat, the value of the work (man's $\mathrm{k}$ sard and wages, keep of team, wear and tear of team and implements) is taken from the farmer's property in cash or produce and added to his investment in the wheat field. In every transaction there is some person who receives value and some person who gives value; or value is added to one kind of property and taken from another.

Incidental accounts are those that cannot logically be charged to any specific account, either to definite persons or to property. These are explained later (p. 35). 


\section{WHAT DOUBLE-ENTRY IS}

The person who receives value, or the property which has value added to it, is a debtor; while the person who gives value, or the property which has value taken from it, is a creditor. It follows that every value exchanged is both a debit and a credit; so, in all accounts, for every amount written on the left or debit side of one account, there must be an equal amount written on the right or eredit side of some other account.

Double-entry is writing each transaction twice,on the debit side of one account and on the credit side of another.

Suppose a farmer sells 100 bushels wheat to the miller on time; the entry on his ledger would be:

\section{FARM Products}

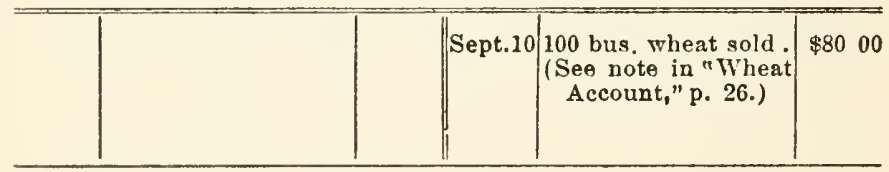

Samuel Pierce, Miller

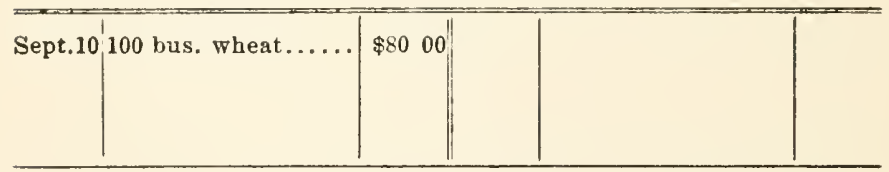

We have learned (page 23) that bookkeeping is the art of making a systematic record of ac-. 
counts. In order to keep books, different kinds of books are required; that is, there must be books for the different stages or epochs in the account. The principal book used in keeping accounts is the ledger. It is the only book essential in a small business having few transactions. It will usually be found more convenient to have a smaller book of some sort in which to record all transactions in the order in which they occur. Once a month, or at any other regular interval, the entries may be transferred or "posted" from this to the proper accounts in the ledger. This smaller book is often called a blotter or day book. Intermediate between the blotter and the ledger is the journal, a kind of condensed blotter; but this is not always used, and it is not described in this handbook.

The blotter may be of the simplest form, and the work reports need not be expensive. Common sheets of foolscap paper may be easily ruled into as many columns as required, since only a ferv sheets will be needed each month. A small ledger suitably ruled (see ruling on page 25) should be purchased.

\section{SUB-DIVISIONS OF ACCOUNTS}

Wo must now decide into how many classes the various operations shall be divided. For. 
instance, the accounts with cattle, swine and chickens are all placed in the former inventory under one generic head-live stock. When we come to wheat or oats, account will not need to be kept with each field but with each crop as a whole. It has been thought best not to carry or open too many accounts at first. Later, when the system has been learned, the live stock account might be divided into three accounts - cattle, swine and poultry. At the end of the year they could be closed into one account-live stock. The data would then be at hand for determining the total profits of live stock, as well as the profits of each one of the three classes of animals. Farm accounts should be learned as we learn other things, by beginning with the simple and proceeding gradually toward the more complex. The aim here will be to give only such details as may be necessary to inform the judgment and explain and illustrate the simplest principles of farm accounts. These, however, do not differ, in the main, from the principles embodied in commercial bookkeeping.

The price of the farm labor must be established. If the men board themselves the matter is simple, but if they receive a fixed price $(\$ 20$ per month) and board with the family, the matter becomes more complex. For illustration: Let it be supposed that the estimated value of board 
is $\$ 12.50$ per month, which, added to the $\$ 20$, makes $\$ 32.50$. The lawful working month in most states is twenty-six days. In the summer the actual hours employed in work each day may average rather more than ten hours when the weather is fair, but in winter the work-day may be less than ten hours. But if account is taken of all these petty differences we shall get into inextricable difficulties, so it is assumed that the work-day is ten hours long. This gives two hundred and sixty hours per month. If the $\$ 32.50$ be divided by 260 , it will show that the price per hour is $12 \frac{1}{2}$ cents. It would be well to avoid complications by assuming that the cost of board is slightly more or less than indicated above. If the board is assumed to be $\$ 11.20$ which, added to the wages of $\$ 20$, gives $\$ 31.20$ as the cost of the hired hand, and this divided by 260 , the number of working hours in a month, we have 12 cents as the cost of an hour's labor. Or, if it be assumed that the month's board is worth $\$ 13.80$ and the wages $\$ 20$ per month, the cost would be 13 cents per hour.

The month hands often work about one hour before breakfast in caring for the cattle or horses, and yet go to the field at seven o'clock, and may make full ten hours' time in the field. If the field be charged ten hours and the stock one hour, it 
destroys the symmetry and harmony of the accounts. In practice, it is usually best to charge the wheat field, for instance, with ten hours and temporarily ignore the other hours. There will be many fractions of days when it will be diffcult to find any legitimate account to which to charge these fractions of days or hours. All farmers know how showers may break up the operations of the day. The workmen come to the barn and wait to see whether they may not go back to the field. The rain continues, and after a time they are set to "tinkering," or, in the absence of the manager, may take the opportunity to ease off the day's labor by pitching quoits; and no one blames men who work from "sun to sun" for doing so. These fractions of days of lost time or half-lost time of the month hands, may be charged to teams or to live stock, as one's judgment may indicate. Then, too, there is always some Sunday work. This had better not be kept account of, or the problem will become still more difficult.

Or, call each work-day ten hours, but charge a just proportion of it to stock or teams, and to hay or wheat field, as the facts warrant. To illustrate: a man who milks morning and evening and works in the field the greater part of the day might have one and a half hours of his time charged to stock and eight and a half hours 
to hay or wheat field, as the case may be. He might have put in more than ten hours, but the proportion of time devoted to stock and to the field would be equitable.

We are of the opinion that if a farm-hi:ld works faithfully ten hours daily the year through, no more should be required of him. I notice that men who work but eight hours per day work much faster and lose fewer odd minutes than those who are kept at it twelve to fourteen hours daily. In the end, it is economy to demand ouly as many hours of men or teams as will enable them to begin work each morning fresh and vigorous, and not with lassitude and pain due to the continuous strain of working too many hours daily.

In like manner, the value of a team per day or hour should be established. It may usually be put down at 15 cents per hour. When but one horse is used, half time is recorded. In the above is included the expense of team and harness, but not of the use of plow, wagon, or other tools required to make the team useful. These will be spoken of later.

All accounts should be set down at the end of each day. A boy or girl twelve years of age can do this work, and be the better for it, if the father or foreman dictate the transactions. The work reports (or time books) and blotters should 
be posted early in each month succeeding the one in which the transactions occur. A work report should always be kept for recording the labor of the proprietor or manager, with suitable price affixed, and each team should have its separate work report. These reports are likely to reveal the astonishing fact that while the man works three hundred days in the year the horses work but one hundred to two hundred days, being "deadheads" the remainder of the time. This, in turn, may lead to finding some profitable work for teams during the winter, or to trading horses until most of the work stock is composed of good brood mares, which may be utilized in raising winter colts when otherwise they would be unproductive.

The work reports provide for thirty-one days in a month. Before recording any accounts on them, draw a line through the dates on which the Sundays occur, to avoid errors. In 1900, the first day of April was Sunday, hence the 8th, 15th, 22d and 29th were Sundays. (Pages 34, 35.)

When a workman is absent for a part or all of a day it should be noted by the letter "a"; otherwise it may not be certainly known whether" the lack of recorded hours is due to careless accounting or to absence. Attention may also be called to the fact that in winter-wheat districts, two accounts with wheat field may be 
running at the same time, as harvesting may be going on in the 1900 wheat field in July, while the ground for the 1901 wheat field is being prepared in the same or the following months. Then, too, when the teams are working for themselves, as they may do in rare cases, it is well to charge up the time to them, that the total earnings of the teams for the year may be known.

It may be well, in beginning to keep accounts, to imagine that the proprietor parts with his property, giving it over to Mr. Teams, Mr. Corn Field, etc.; that is, he has personified all accounts, thinks of them as individuals, and thinks of himself as an accountant until the end of the year, when he will settle with the various persons personified accounts - and see which have made a profit and which a loss.

Incidental accounts (pp. 35-38). Under this name are included many indefinite rumning expenses (p. 27). Such accounts seldom have any natural credits, and therefore are sometimes treated as single-entry or memorandum accounts. However, a double-entry system may be made by making Cash, or some other account, the other side of the entry. Bear in mind that incidental accounts represent a general class of accounts. Amongst these accounts may be a Contingent Account, Farm Household, Personal Expense, and other accounts. 
It has seemed best not to open a detailed account with Farm Household here, as it would involve cumbersome details, and little would be gained; since the forms and methods of keeping it would be similar to those of teams, stock, and the other accounts which start out with an inventory charge. However, if it is thought best to open such an account, the value of the board of the proprietor, if he works on the farm, and of such workmen as board in the family, should be credited to Farm Household. On the other hand, all expenses should be debited to Farm Household or to Personal Expense account. But in such a system we should be met with a mass of petty details. The entries would be many: goods for the home, board of guests, charities, traveling expenses for pleasure or health, clothing bill, etc.

If no detailed account is kept with Farm Household, there may still be an account kept with Personal Expense, in which may be entered all expenses incurred for the last three of the objects named above. Often butter or eggs will be exchanged for groceries. If the farmer wants to know exactly the profit made from the dairy or from the poultry, these items must be credited to live stock or to the dairy, as the case may be; and since there is both a debtor and a creditor in every transaction, there must be some account kept with the debtor 
in these transactions, which is Farm Household. The Personal Expense may include a great number of items, and it requires less detail than a full account with Farm Household.

In the methods outlined, those accounts which belong to the business as a whole but which can not well be charged to wheat field or any other special account, have been charged to a Contingent Account. Since the Contingent Account seldom or never has a credit, the apparent loss will, in reality, be deducted from gross gains. The same will be true, to a certain degree, of expenses incurred in the household, since they will nearly all be debtor charges unless credits appear by reason of workmen boarded in the family. Contingent Account must be carefully distinguished from Personal Expense.

We shall meet with some slight difficulty, in practice, when an account with Farm Household is not kept; but the busy farmer may meet with many more if he tries to keep such an account. For instance, in the eggs and butter traded at the store for sugar or coffee, it is evident that the value of the former must be credited to live stock; but if there is no account with Farm Household, which uses the groceries, there can be no debit side to the entry. Since there cannot be a credit without a debit nor a debit without a credit, we can overcome the difficulty by ignoring the 
debits entirely and using what is really a singleentry system. But the professional bookkeeper will immediately answer that this is not a correct method of keeping books. This is granted, and it emphasizes the desirability of keeping an account with Farm Household.

It may be said that the farmer really has no cash drawer: he cannot count up cash every night to see whether any mistakes have been made in making change or from any other cause. What he can do is to count cash at the end of the year and to add inventories of all values, as teams, stock, etc., and thus determine his present worth. That, compared with the worth of all his property at the beginning of the year, will indicate correctly the total losses or profits of the year, and the detailed accounts with wheat field, stock and the like, will give a close approximation to the gains or losses of the various minor undertakings.

\section{WORK REPORTS, OR TIME BOOKS}

The following work reports are, in the main, self-explanatory. It should be said, however, that they are adapted to double-entry bookkeeping, and it will be well for the student to grasp that fact in the beginning. When the items in the report are entered in the ledger, teams, hay field, contingent, and the like, will be debited 
with the various amounts set opposite to them and in due proportion as they have received values from the labor of $\mathrm{Mr}$. Brown. On the other hand, Mr. Brown has parted with valuelabor-equal to the sum total of all the various debts, $\$ 32.50$-and, therefore should be credited by this amount. Double-entry is used in all of the accounts, that errors may be minimized. If errors are made, double-entry assists in discovering them. Consider the first work report for illustration. If the column headed "hour's" does not add up 260, in this particular case, attention is called to the fact that the man has lost time or that the hours have not been set down or added correctly, or that an error has been made in adding up the column. If a mistake is made in multiplying the various numbers of hours by $12 \frac{1}{2}$, the price per hour, then the sum total in the last column will not be $\$ 32.50$. To prove the sum total, simply multiply 260 , the total number of hours, by $12 \frac{1}{2}$.

Prove each work report as above before the various accounts are posted to the ledger. If the total number of hours be an odd number, as is the case in the account with Hay Field and Orchard, the half-cent is dropped in one case and added in the other, or Hay Field is charged with $\$ 4.12$ and Orchard with 63 cents. This treatment will eliminate half-cents when the accounts are posted to the ledger. 


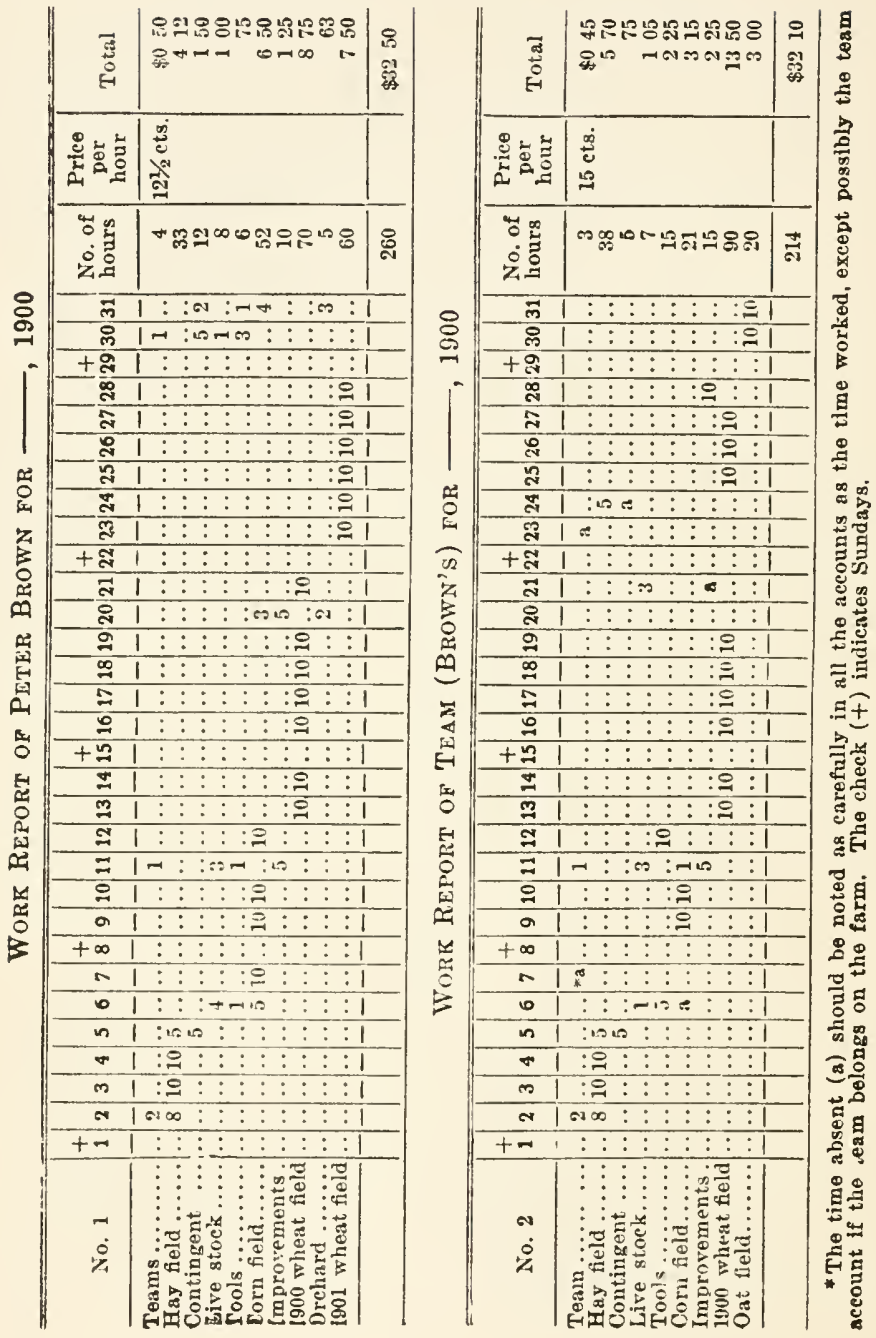




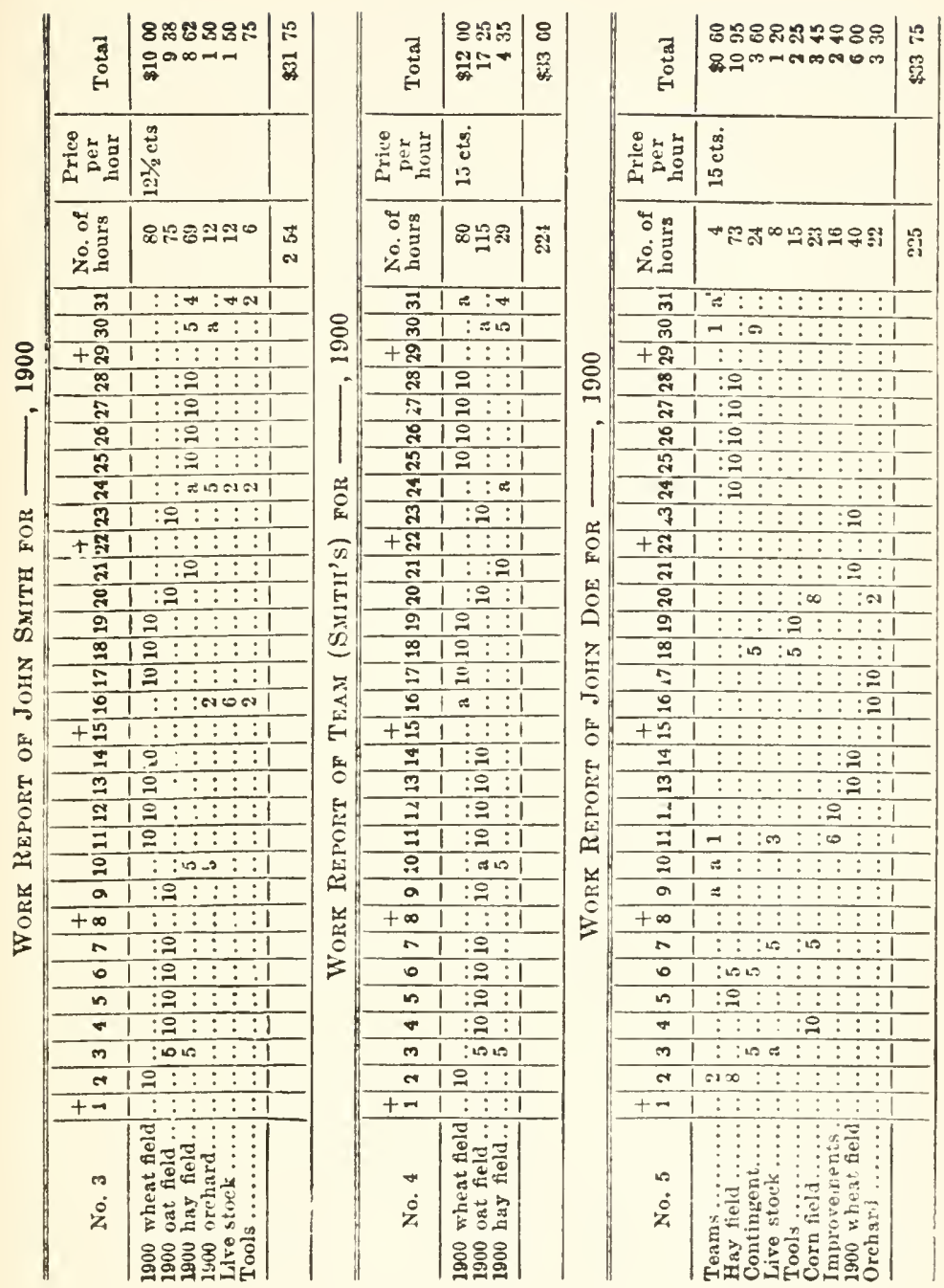




\section{CHAPTER III}

\section{THE BLOTTER}

THE sample blotter that follows contains many more entries than would be necessary on an ordinary farm in a single month. Most of them are necessary here, however, as examples of the varied transactions that occur in practice. In other words, the year has been compressed into a single month, but this fact need not mislead. In practice, many more work-report entries and a few other blotter entries would be necessary if the entire year's transactions were recorded.

In teaching farm accounts to students, the difficulties have appeared to arise from a lack of reasoning power. Too often pupils start with the idea that farm accounts are to be mastered in the same way that a lad masters the spelling book. The effort is made here to enable them not only to master the text but to appreciate the fact that there can not be a debit without a credit, nor a credit without a debit. Most people take account of one side of a transaction, sometimes the credit, sometimes the debit, but seldom consider both at the same time. Any 
person or account which receives value is a debtor, and any person or account which has parted with value is a creditor. The beginner would better' think of the debtor side first and record this side of the transaction first, on the left-hand page, if there are two pages-one page for debtor and one for creditor-Or on the left-hand side of the single page, as shown in the blotter here. In making entries, let the writing be upright and compact, and above all distinguish sharply between the figures 3 and 5, 7 and 9 , and 6 and 0 . In fact, make all figures so plain that "he who runs may read" them correctly. If the college student has some difficulty in comprehending all of the various transactions, with the instructor at hand to explain, it will readily be seen that the student without a teacher will have more difficulty. This being so, he will be wise who takes up each one of these entries in detail and imagines the transaction which must have occurred to give rise to the entry.

For illustration, let the fourth entry be taken (p.47). Mr. LaPoint shod the horses and was paid in cash. Teams received value and Cash parted with value; therefore, the former is debited because value was received, and the latter credited because value was given. If the transaction is looked at carelessly it may be thought that La Point should be credited, but the only object in 
introducing his name is to indicate who shod the horses, which fact may some time be of value. An explanatory word at the end of an entry is often valuable, but should not be confounded with the principals in the transaction.

The Cash Account sometimes confuses the beginner. If Cash is personified, or the money is thought of as all being kept in one drawer, the cash account may be the better understood. If the money is put in the cash drawer, the drawer (Cash) is debited, since it receives value; if money is taken out of the drawer then the drawer (Cash) receives credit, since it parts with value.

At the end of the year all open book accounts should be balanced (although the debit and credit balances may not be paid at the time), for this is the only way of determining how much is receivable and how much payable on book accounts.

For convenience, the farmer may open an account with Bills Payable, and under it record, either during the year or at the end of the year, all bills, notes and interest accrued to date, closed book accounts and other evidences of his indebtedness (except the mortgage on the farm, if there be one) on the debit side.

He may also open an account with Bills Receivable. Under this head he records, on the credit side, promissory notes and accrued interest thereon, bills receivable and amounts on the 
closed book accounts due him and other evidences of moneys uncollected. If he holds a mortgage on his neighbor's farm, this may be placed with his assets at the beginning of the year.

This, to be sure, is not the usual way of keeping track of these accounts; but when accounts are not extended and there is no trained bookkeeper, we may strain the ordinary rules of aecounting and carry several kinds of similar accounts under these two heads of Bills Receivable and Bills Payable: one implies an account of the amounts we owe, and the other an account of the amounts which others owe us. Simplicity and ease of reference will be greatly aided if the amounts of all our debts, except the mortgage, be thus gathered together under one head, and all amounts due us, except the mortgage, be gathered under another coördinate single head. Howevir, when the business is large and complicated it is necessary to open a greater number of accounts for these items, one with notes, another with interest, and others with the different persons.

The word "to" follows debtor and the word "by" credit: thus, Peter Brown debtor to; Orchard credit by. Usually the words are not repeated, since the name or account standing at the left is debtor and the account standing at the right of the page is creditor.

It is believed that these explauations will clear. 
up some of the perplexities which are so often encountered by the pupil when accounts are considered, provided, however, that the explanations are studied carefully. If they are not, additional explanations would be useless.

Some of these explanations apply to the ledger, which has not yet been reached; but it has seemed best to make them here, otherwise some of the entries in the blotter would not be understood. As each entry in the blotter is made, the pupil should have clearly in mind the nature of the transaction. Consider, for instance, the transaction near bottom of page 48. Live Stock is debtor; Corn Field creditor. The corn and stalks have both been charged to Live Stock, because it is presupposed that the cattle will use these products. Corn Field is credited because it furnished value. Should there be some corn left over when the inventory is made out the next spring, it would be inventoried with other assets of live stock belongings. Should fifty bushels of the corn be wanted for teams before the fiscal year closed, then the following entry would appear in the blotter:

Teams Dr. to Live Stock, 50 bushels of corn.................... $\$ 2500$

Whenever one account receives value from any other account, a similar entry should be made. 


\section{BLOTTER - 1900}

$\begin{array}{ccc}\text { Dr. } & \text { APRIL 2 } & C r . \\ \text { Peter Brown } & \text { Orehard } & \end{array}$

6 bushels apples, at 50 cents....

APRIL 3

Contingent

Cash

Expenses at Rochester........

APRIL 4

Johu Smith

Farm Products

10 bushels wheat, at 60 cents....

\section{APRIL 7}

Teams

Cash

Shoeing bill (at LaPoint's)....

825

APRIL 10

Improvements

Building 40 rods fence, at $12 \frac{1}{2}$

John Bryant

cents ...............

APRIL 12

John Bryant

Farm Products

60 bushels wheat, at 70 cents...

Live Stock

J. Smith

1 yearling calf..............

APRIL 14

John Bryant

Teams

Gray horse Jiu.

........... 6000

Cash

Note of John Rice paid.......

Bills Receivable

Interest*................

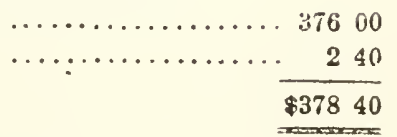

-See explanation under "Bills Receivable," p. 45. 
Casin

$13 \frac{1}{2}$ bushels apples, at 40 cents

(John Rice) ...........

1900 Wheat Field

15 bushels seed wheat, at $\$ 1$ per

bushel

John Bryant

14 bushels apples, at $20 \mathrm{cts} . .$. .
Orchard

$\$ 540$

Cash

Orchard

280

APKIL 16

Peter Brown Cash

Tools

Repairs on reaper (by Martins)

Teams

Paid Wall \& Co., repair har-
Cash

1000

Cash

429

Cash

368

\section{APRIL 20}

\section{Improvements}

Building 30 rods fence, at 15 cents.

Live Stock

100 bushels corn, at 50 cents 5 tons stalks, at $\$ 3 \ldots \ldots \ldots$.

Cash

Received for milk. .........

\section{Teams}

5 tons hay, st $\$ 8$
John Bryant

450

Corn field

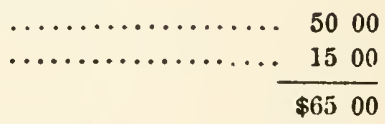

Live Stock

$\$ 4236$

Hey Field 


\section{ApriL 25}

Live Stock

4 tons clover hay, at $\$ 7$

Cash

2 colts (sold to Bush) .......

Bills Payable

Grocery bill paid (Henry Bell)

Store bill, paid (C. Bessey)....

Cash

Bay horse (sold to Jones).....

John Smith

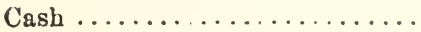

Hay Field

2800

\section{Teams}

Cash
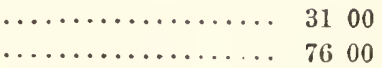

$\$ 10700$

Teams

$\$ 16000$

Cash

2000

\section{APRIL 27}

1900 Wheat Field

Threshing bill, 300 bushels wheat, at 5 cents ......... Paid John Buck, two days' threshing............

Paid Buck, use of team......

Cash

Received for eggs

Teams

5 tons hay, at $\$ 8$

\section{Teams}

100 bushels oats, at 30 ets.....

Cash

310 bushels wheat, at 75 cents. .
Cash

1500

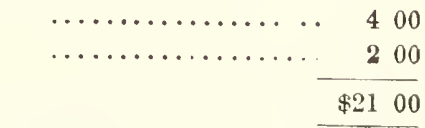

Live Stock

Hay Field 4000

Oat Field ............. 3000

Farm Products 23250 
Cash

300 bushels wheat, at 80 cents.

Cash

John Burroughs, paid note....

Tools

Paint and repair of carriage,

B. Rich

Repair of harrow and plow...

Improvements

Cutting 10 cords of wood, at 75

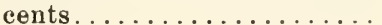

\section{Cash}

10 cords of wood, at $\$ 3$ per cord, sold to J. Bent

John Doe

Cash

\section{Wheat Field}

Six days, man and team, $P$.

Handy, $\$ 2.50$ a day ......

Orchard

Two days' picking fruit, D.

Hill ............................

\section{Peter Brown}

2 bushels peaches.

$1 / 4$ bushel cherries
1900 Wheat Field .$\$ 24000$

Bills Receivable 16325

Cash

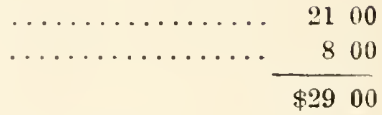

John Bryant

$\$ 750$

Improvements

$30 \quad 00$

Cash

3375

Cash

Cash

300

Orehard

200

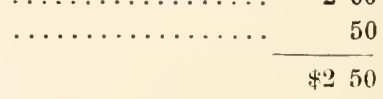


1901 Wheat Field

30 bushels seed wheat, at 80 cts.

Teams

Span of 3-year-old fillies.....

Peter Brown

Cash

Cash

96 barrels apples, at $\$ 1.25$. . .

Cash

60 bushels coln, at 40 cents ...

Cash

200 yriarts cream, at 35 cts.....

1900 Wheat Field

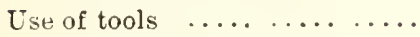

1901 Wheat Field

Use of tools.............

\section{Teams}

Use of tools.

Oat Field

Use of tools

Coln Field

Use of tools

Live Stock

Use of tools

Hay Field

Use of tools

\section{Farm Products*}

$\$ 2400$

Cash

27500

Cash

1700

Orchard

Corn Field

2400

Live Stock

Tools

Tools

600

Tools

1200

Tools

800

Tools

Tools

279

Tools

600

* When the inventory is taken, all products, such as wheat, hay and oats, are charged to "farm products" account. Oats, hay, and the like, which have already been charged to teams or live stock, are excepted. If any is left over at the end of the year it should be inventoried with teams or live stock, as the ease may be. 
The last seven credits to Tools cannot ve entered until all other entries have been made and the inventory at the end of the year has been taken. Turn to page 62 and note that the sum of all debit charges against Tools amounts to $\$ 447.79$, and on pages 12 and 63 the second inventory amounts to $\$ 396$. This leaves a deficit or apparent loss of $\$ 51.79$.

It is evident that the tool account, which is simply one of convenience, should show neither profit nor loss. Since several of the other accounts or divisions have received benefit in the use of tools, they should be charged such amounts for their use as appears to be just. This deficit, $\$ 51.79$, should be distributed equitably among the accounts using the tools. Here good judgment must be used.

Since the teams, in order to be efficient, must use wagons and other expensive tools, $\$ 12$ has been charged to them. In like manner other accounts have been charged with respective sums, the total of which just equals the $\$ 51.79$, which makes the debit and credit sides exactly balance, as they should.

The work reports, the blotter and inventories will all have been posted before this distribution of the tool account can be made. When it is made and entered in the blotter and posted to the ledger, the ledger is ready to be closed. 


\section{CHAPTER IV}

\section{$T H E$ LEDGER}

Having made the original entries in the work reports and blotter, in double-entry form, the ledger accounts may now be opened.

As in Chapter I, the first step in starting a farm account is the taking of an inventory in detail of the personal property, as found on page 9. Since one detailed inventory has already been given, it will be necessary only to give a summary similar to the one found on a preceding page.

Note, however, that household account is left out in the following examples, since if details were entered into it would greatly increase the number of items and tend to confuse the productive with the personal and non-productive accounts.

Summary of Inventory Taken May 1, 1900 (seo p. 23)

Teams........................... \$62800

Live stock.......................... 49200

Farm tools ....................... 40850

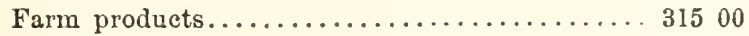

Bills receivable...................... 53925

Cash on hand ......................... 37500

Bills payable................. \$107 00 $\$ 2,75775$

Net assets................... 2,650 $75 \quad \$ 2,757 \quad 75$

(53) 
The natural order of all accounts which have inventories will be indicated by the inventory. The value of teams is found to be $\$ 628$ at the beginning of the year. An account is now opened with Teams, the debits on the left-hand page and the credits on the right-hand page. The first entry is the debit charge against 'Teams, - of theil' inventory value. In like manner a debit and eredit account is opened with Live Stock, Farm Tools, Farm Products, Bills Receivable, Cash, and with the Farmer to show his net assets. Farm Household, it should be remembered, has been left out in this case in order to prevent too great complication. (See page 35.) At least once each year all running accounts should be settled and a due bill or note given for the balance.

These entries from the inventory are called the "opening entries." The farmer's ledger after the opening entries are made appears as follows:

TEAMS

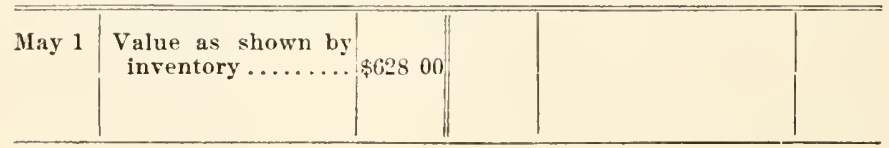

Live STOck

May $1\left|\begin{array}{c}\text { Value as shown by } \\ \text { inventory .......... } \$ 492 \text { 00 }\end{array}\right| \mid$


FARM TOOLS

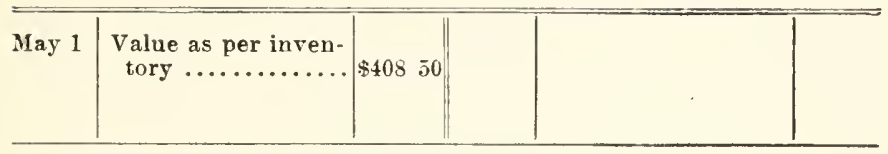

Farm Products

May $1\left|\begin{array}{c}\text { On hand as shown } \\ \text { by inventory...... } \$ 31500\end{array}\right|$

Bills Receivable

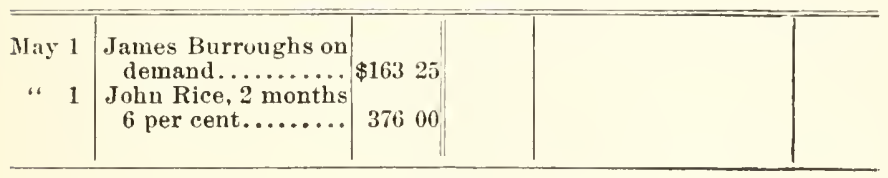

CASH

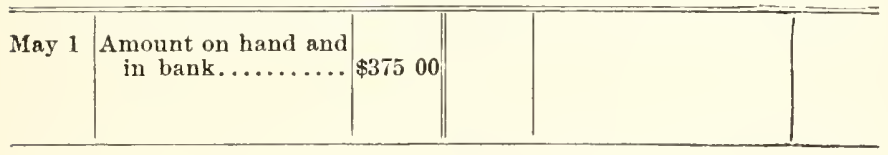

Bills Payable

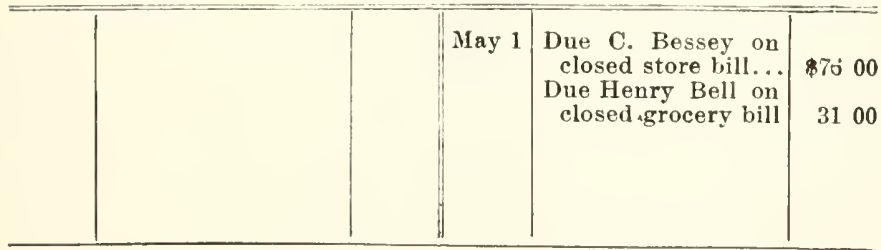

A complete ledger should show that the sum of all the entries on the debit side is equal to 
the sum of all the entries on the credit side, and this is continually so (if no error has been made), no matter how great the number of entries. This enables one to prove the correctness of his work at any time, and it will be spoken of later when we come to the "Trial Balance."

The last charges in all accounts having inventories will be credits "by inventory," these being the respective values of the teams, tools, etc., having inventories at the end of the year.

Note, also, that when the total value of all assets is found at the end of the year the amount of debts (bills payable) must be deducted, as at the beginning of the year. It is evident that the difference between the net assets at the beginning and the end of the year will show the total profit or loss. If the value of the net assets at the close of the year be greater than at the beginning, the difference will be profit; if less, there will be a loss. Following is the final balance:

FARMer (Net Assets)

$|\quad|$\begin{tabular}{c|c|c|c|}
\hline $1900 \begin{array}{c}\text { Value of property } \\
\text { over all debts.... } \\
\text { [alance from foot- } \\
\text { ings of previous } \\
\text { accounts.] }\end{array}$ & $\$ 2,65075$ \\
\hline
\end{tabular}

These ledger accounts may be kept on one page, ruled as the above accounts are, or on two opposite pages as illustrated further on (page 60 and advance). 
After the inventories have been entered in the ledger, posting the accounts from the work reports and blotter should proceed systematically and with a view to minimizing the chances of mistakes. First enter into the ledger (from the work reports) all of the debit charges, checking off each item as entered, thus $V$, or thus $\|$. Then enter the credit side of the account and check in like manner. In the work reports it is evident that the teams and men are to be credited, since they parted with value, and the various accounts which have received value debited. In like manner post from the blotter.

In the ledger, as the accounts are posted, note by letters or page of blotter from whence the accounts have been posted, that the original entries may be found quickly if desired. If the item comes from the work reports, which will probably not be paged, letters would better be used. Apr. W. T. means that the item was posted from April work report of teams. Figures or letters may be used to indicate the items posted from the blotter, as B 6 indicates that the item came from blotter page 6 , or $\mathrm{B} \mathrm{Apr} .6$ would show that the original charge was made in the blotter under date of April 6. These methods of indicating the source of the entries are only suggestive, as any other method may be adopted which will surely indicate in the 
ledger the place where the original entry may be found.

The accountant should get a clear conception of debtor and creditor and of double-entry accounts before opening a set of books. If any account is debited,- - for instance, Peter Brown (see first charge in blotter, p. 47), with $\$ 3,-$ some other account or accounts must be credited with a like amount. In this case it is Orchard. Or, consider the first work report, Peter Brown's. Ten accounts have been debited with various sums, the total amount of which is \$32.50. Peter Brown has been eredited with this amount for labor, so it is evident that the total debit charges should be equal to the total credit charges.

On April 2 apples were sold to Peter Brown; and on April 14 apples were also sold to John Rice (p. 48), but he is not debited with them because he paid for them. In this instance Cash received value and is, therefore, debited; Orchard parted with value in both cases and therefore received credit in both cases.

On the 14th a horse was purchased (p.47), and was turned over to Teams' account and will find a place in the inventory at the end of the year. On the 25th two colts were sold for cash (p.49). Cash must then be debited and Teams credited, since Teams parted with value. On the 12th a calf was purchased (p. 47). This is debited to 
Live Stock, because the accounts of all of the live stock, except horses, are kept under the head of Stock or Live Stock. The live stock account might in practice be subdivided into cattle, swine, sheep and poultry, as the numbers and importance of each should justify.

Soon after harvest the hay and grain expecter to be consumed on the farm should be charged to the class of stock which is expected to consume it, and that which is expected to be sold charged up to farm products, while the various fields or crops would receive credit. For instance, if a part of the hay, which had been charged to Farm Products, was needed later for teams or stock, such amounts as were used should be charged to them and Farm Products credited with the same amounts.

Observe that all the entries in the ledger have been posted from either the blotter or the work reports, and that the object in doing so is to get all the debit and credit charges of each account together in order that the condition of the account may be seen at a glance. True, if the blotter and work reports were left unposted there would be a record of all transactions, but they would be so scattered that they would be of little practical value.

Further instructions on balancing the ledger will be found on pp. 72-75. 
THE LEDGER: THE OPPOSITE PAGES

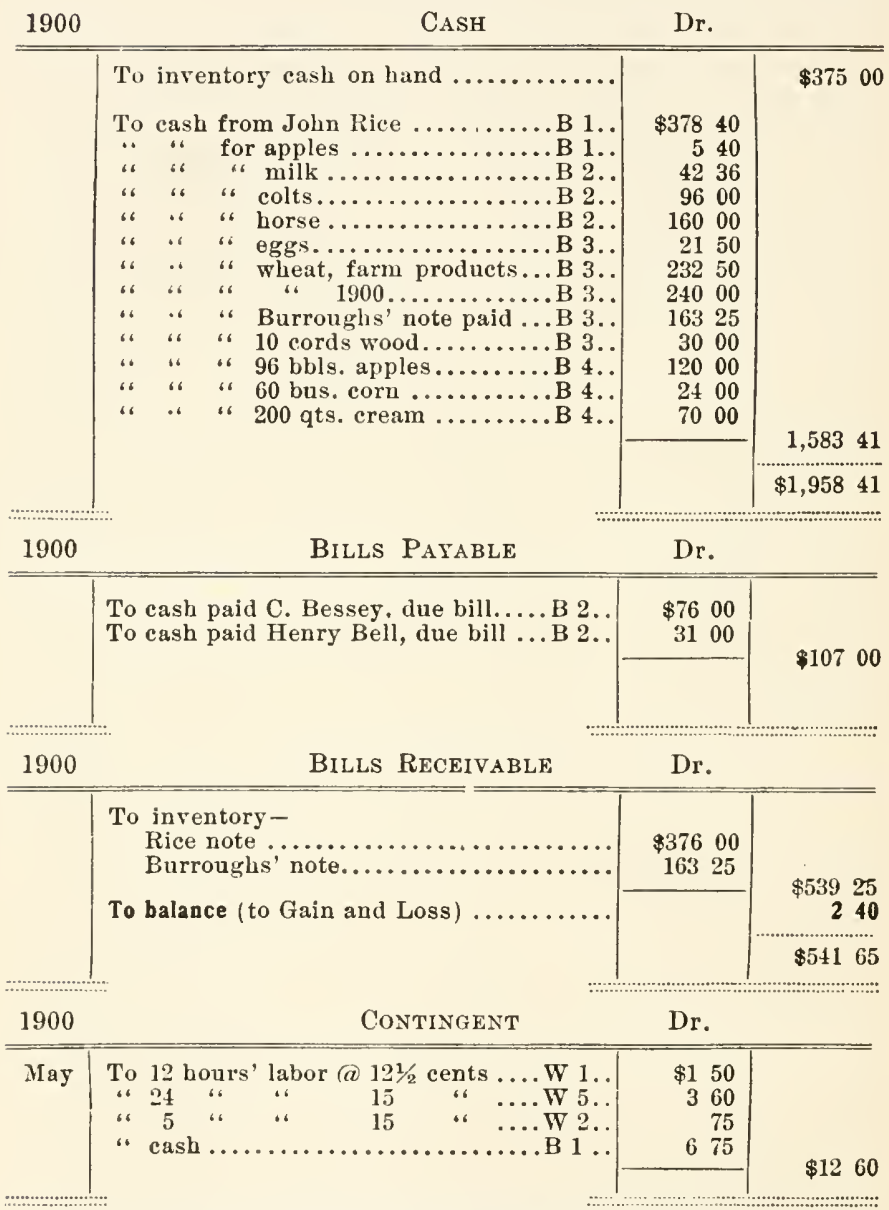

Note.-Dotted lines and heary-face figures are to indicate red ink; in parentheses are given the new accounts to which the red ink entries go. These new accounts may be continued on the same page or transferred to another book. 
SHOW THE TWO SIDES OF THE ACCOUNT

$1900 \quad \mathrm{CASH} \mathrm{Cr}^{2}$

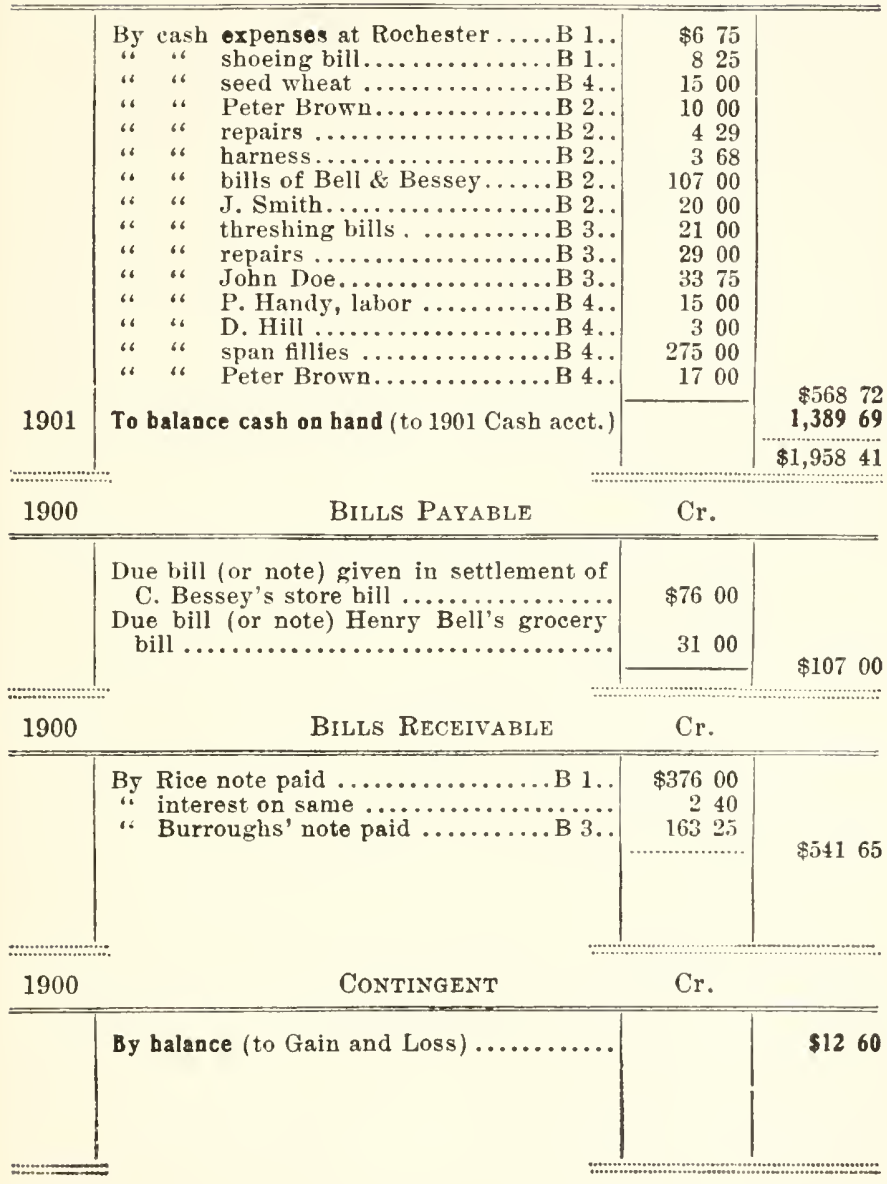


THE LEDGER: THE OPPOSITE PAGES

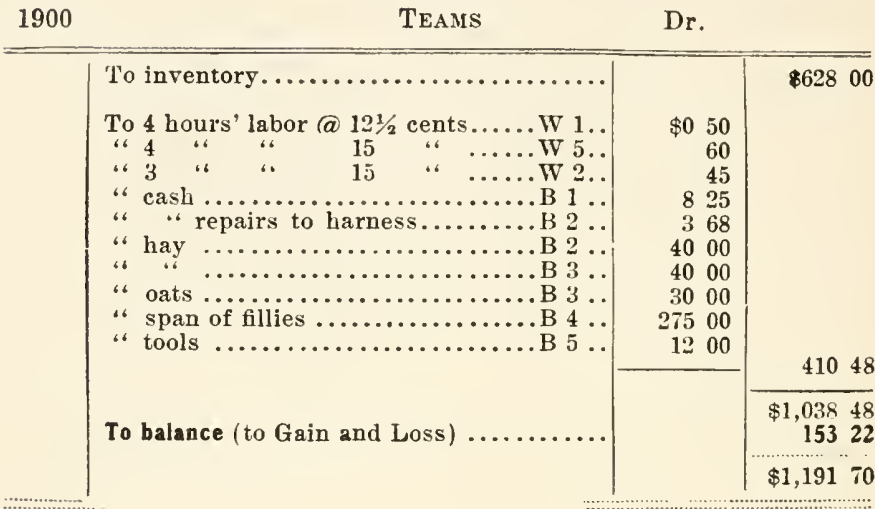

1900 FarM TOOLS Dr.

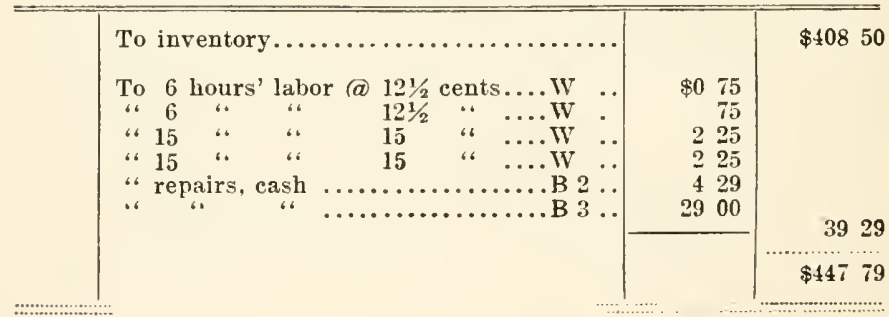

1900 FARM PRODUCtS Dr.

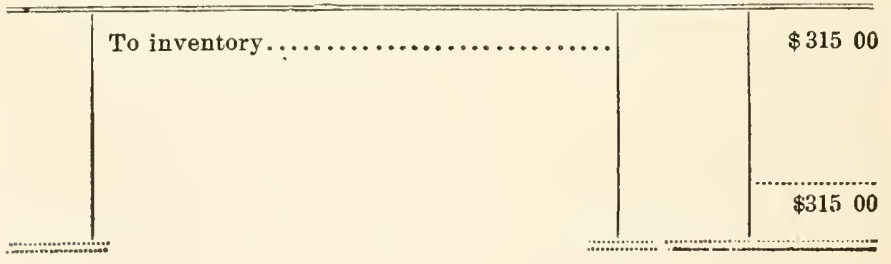


SHOW THE TWO SIDES OF THE ACCOUNT

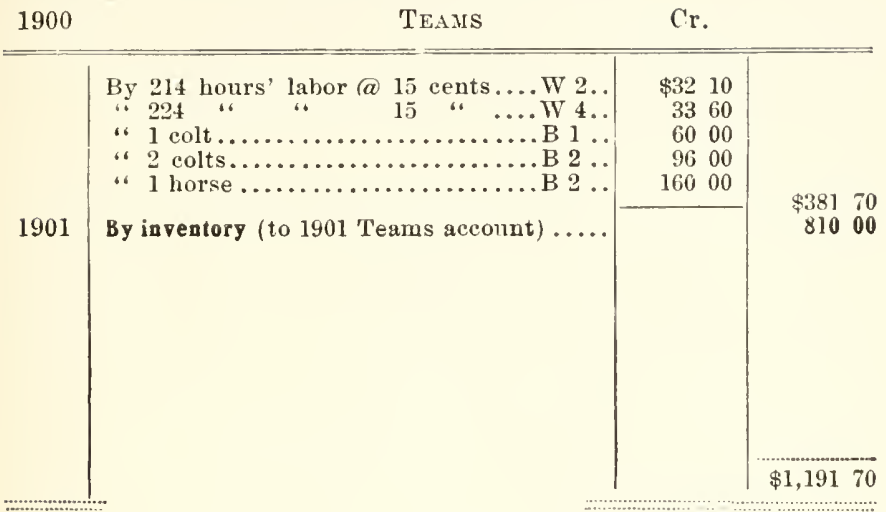

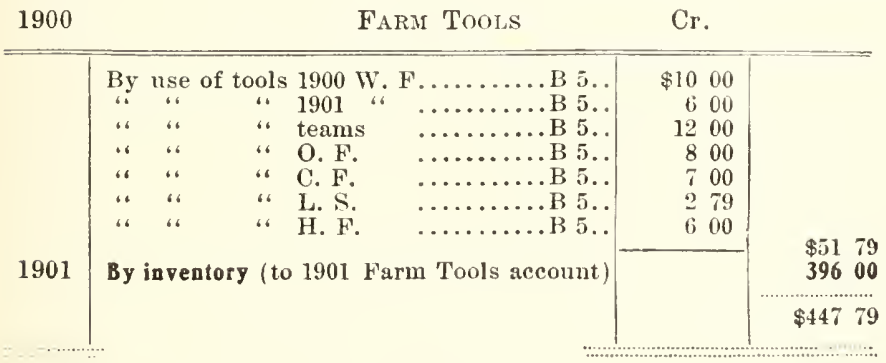

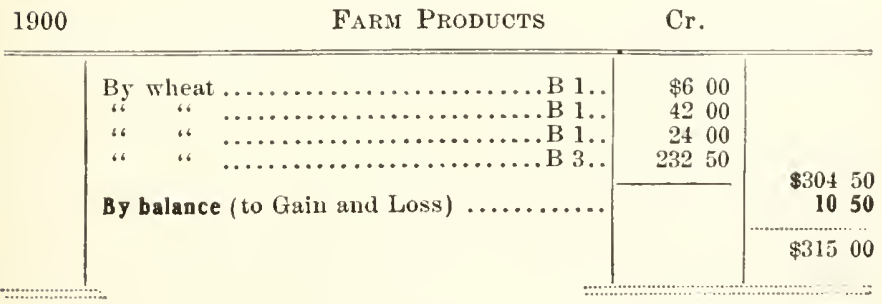


THE LEDGER: THE OPPOSITE PAGES

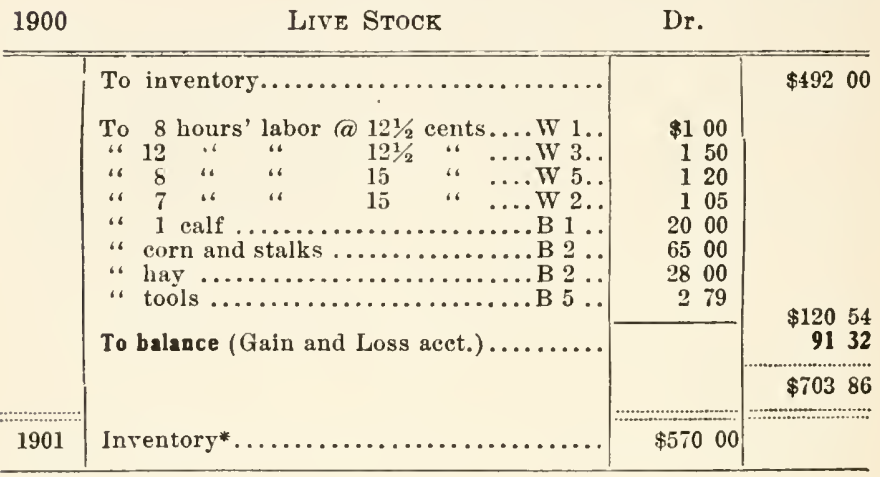

\begin{tabular}{c}
1900 HAY FIELD \\
\hline \\
\hline \\
\hline
\end{tabular}

1900 CoRN Field Dr.

\begin{tabular}{|c|c|c|c|}
\hline \multirow[t]{2}{*}{ May } & 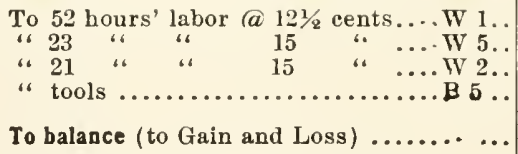 & $\begin{array}{rl}\$ 6 & 50 \\
3 & 45 \\
3 & 15 \\
7 & 00\end{array}$ & $\begin{array}{r}\$ 2010 \\
6890\end{array}$ \\
\hline & & & $\$ 8900$ \\
\hline
\end{tabular}

* This shows how the new (1901) Liye Stoek acconnt is opened. 
SHOW THE TWO SIDES OF THE ACCOUNT

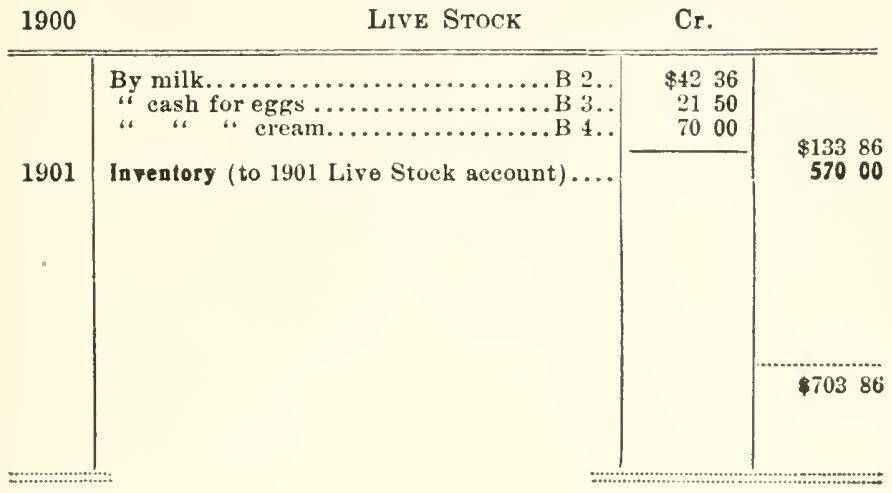

1900 HAY Field Cr.

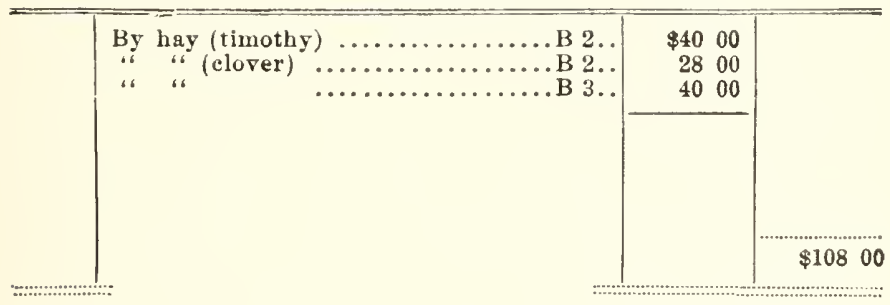

Cr.

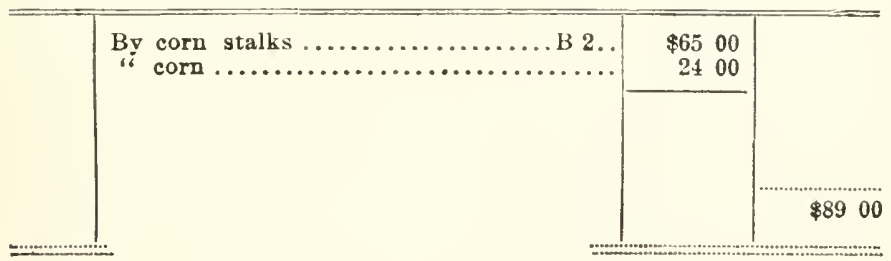


THE LEDGER: THE OPPOSITE PAGES

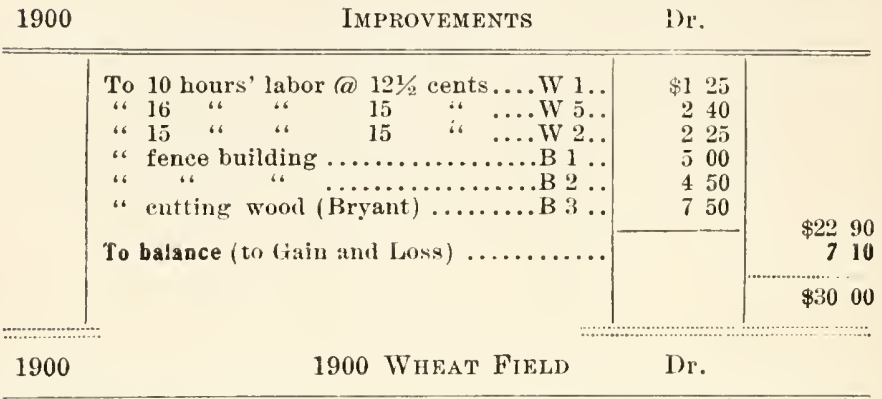

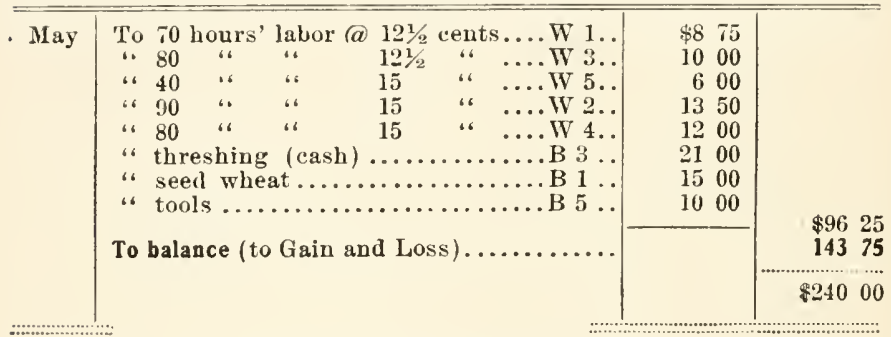

\begin{tabular}{|c|c|c|c|}
\hline 1901 & 1901 WHEAT FIELD & Dr. & \\
\hline & 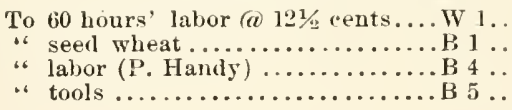 & $\begin{array}{rr}\$ 7 & 50 \\
24 & 00 \\
15 & 00 \\
6 & 00\end{array}$ & \multirow{2}{*}{$\$ 5250$} \\
\hline \multicolumn{2}{|l|}{1900} & Dr. & \\
\hline \multirow[t]{3}{*}{ May 1} & 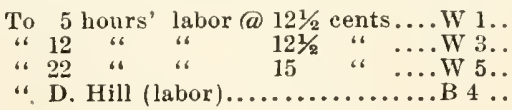 & $\begin{array}{rr}\$ 0 & 63 \\
1 & 50 \\
3 & 30 \\
3 & 00\end{array}$ & \multirow{2}{*}{$\begin{array}{r}\$ 843 \\
125 \quad 27\end{array}$} \\
\hline & To balance (to Gain and Loss) .............. & & \\
\hline & & & $\$ 13370$ \\
\hline
\end{tabular}


SHOW THE TTO SIDES OF THE ACCOUNT

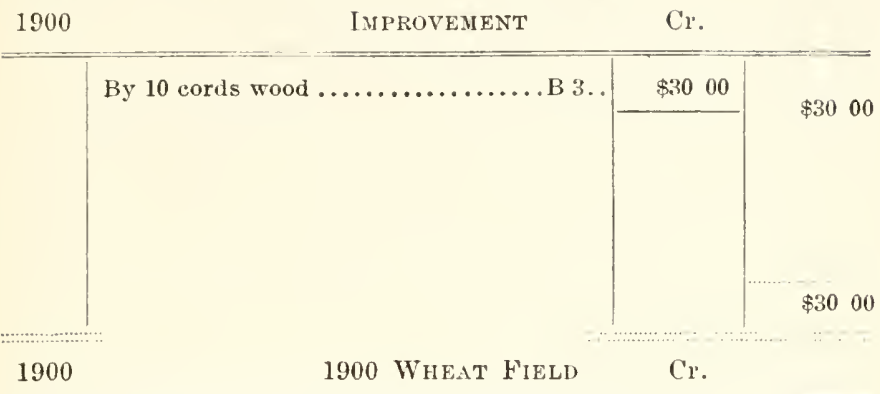

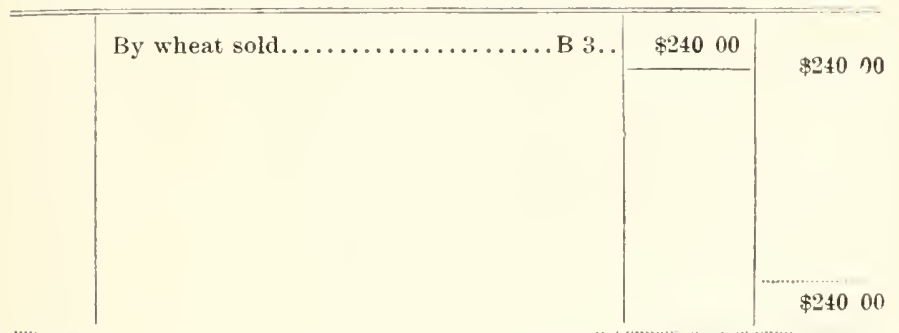

Cr.

\begin{tabular}{|c|c|c|c|}
\hline May 1 & By ralue of wheat in ground............. & $\$ 5250$ & $\$ 5250$ \\
\hline 1900 & ORCHARD & $\mathrm{Cr}$. & \\
\hline \multirow[t]{2}{*}{ May 1} & 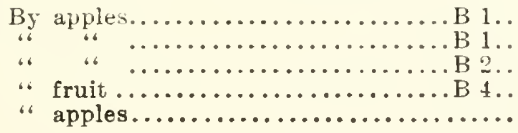 & $\begin{array}{rr}\$ 3 & 00 \\
5 & 40 \\
2 & 80 \\
2 & 50 \\
120 & 00\end{array}$ & $\$ 13370$ \\
\hline & & & $\$ 13370$ \\
\hline
\end{tabular}


THE LEDGER: THE OPPOSITE PAGES

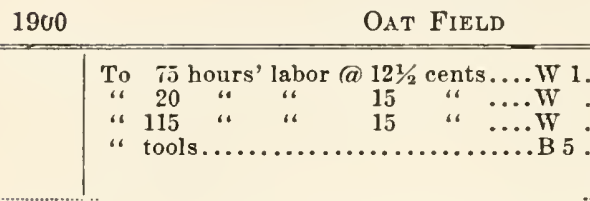
Dr.

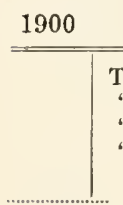

PETER BROWN

\begin{tabular}{r|r|}
$\$ 9$ & 38 \\
3 & 00 \\
17 & 25 \\
8 & 00 \\
\hline
\end{tabular}

$\$ 3763$

\begin{tabular}{|c|c|c|c|}
\hline 1900 & JOHN BRYANT & Dr. & \\
\hline & 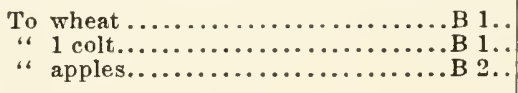 & $\begin{array}{rl}\$ 42 & 00 \\
60 & 00 \\
2 & 80\end{array}$ & $\$ 10480$ \\
\hline 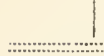 & & & $\$ 10480$ \\
\hline 1900 & JoHN DOE & Dr. & \\
\hline & To cash........................... & $\$ 3375$ & $\$ 3375$ \\
\hline 1900 & JoHN SMITH & Dr. & \\
\hline & 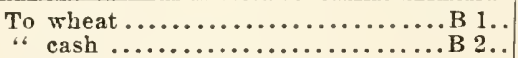 & $\begin{array}{l}\$ 600 \\
2000\end{array}$ & \\
\hline & To balance (to Bills Receivable) ........... & & 2575 \\
\hline & & & $\$ 5175$ \\
\hline & Farmer (Net Worth) & & \\
\hline
\end{tabular}

$\mid$\begin{tabular}{l|l}
\hline Net worth, May, 1901 (to 1901 Farmer's acet.) $\mid$ & $\begin{array}{l}\$ 3,28024 \\
\ldots 3,28024\end{array}$ \\
\hline
\end{tabular}


SHOW THE TWO SIDES OF THE ACCOUNT

\begin{tabular}{c}
1900 \\
\hline
\end{tabular}

\begin{tabular}{|c|c|c|c|}
\hline 1900 & Peter Brown & $\mathrm{Cr}$. & \\
\hline & By260 hours' labor @121/4 cents... & $\$ 3250$ & $\$ 2950$ \\
\hline & . & & $\$ 3250$ \\
\hline 1900 & JoHN BRYANT & Cr. & \\
\hline
\end{tabular}

\begin{tabular}{|c|c|c|}
\hline 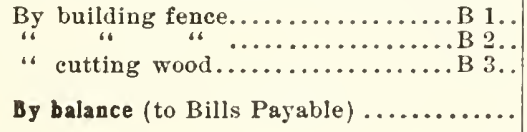 & $\begin{array}{rl}\$ 5 & 00 \\
4 & 50 \\
7 & 50\end{array}$ & $\begin{array}{r}\$ 1700 \\
8780\end{array}$ \\
\hline & & $\$ 10480$ \\
\hline
\end{tabular}

\begin{tabular}{|c|c|c|c|}
\hline 1900 & JOHN DOE & Cr. & \\
\hline & 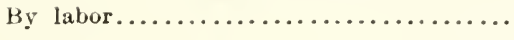 & $\$ 3375$ & 92375 \\
\hline 1900 & JoHN SMITH & Cr. & \\
\hline & 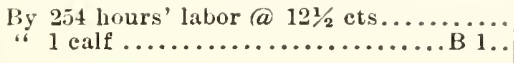 & $\begin{array}{rr}\$ 31 & 75 \\
20 & 00\end{array}$ & \\
\hline & & & $\$ 5175$ \\
\hline
\end{tabular}

1900 FARMER (Net Worth)

\begin{tabular}{|c|c|c|c|}
\hline \multirow[t]{2}{*}{ May 1} & 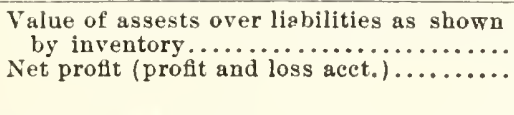 & $\begin{array}{r}\$ 2,65075 \\
62949 \\
\end{array}$ & $\$ 3,28024$ \\
\hline & Net worth, May, $1901 \ldots \ldots \ldots \ldots \ldots \ldots$. . . . & & $\$ 3,28024$ \\
\hline
\end{tabular}




\section{CHAPTER V}

\section{THE TRLAL BALANCE}

To determine whether the debits and credits have been correctly posted in the ledger, a "Trial Balance Sheet" is prepared. If the sum of all the debits is equal to that of all the credits, it is good evidence that the books have been correctly posted. Peter Brown, in the blotter, is debited with $\$ 3$, and, through carelessness, Farm Products, instead of Orchard, might be credited with this $\$ 3$, but such mistakes seldom occur. This is called "posting to the wrong account," and the Trial Balance will not reveal such error. A Trial Balance results from placing the sum total of all debit charges of all accounts in one column, and all the credit charges of all accounts in a like column. If the sum total of all the debits in the first column equals the sum total of all the credits in the second column, the posting has been correctly done. The balances and the last inventories are not entered in the ledger until after the Trial Balance is taken.

Sometimes the inventory is entered in red ink, in order to attract attention. In this book, the figures 
which express the value of the inventories have been placed in bold-face type for the same pur. pose. Below is the trial balance sheet, which embraces all footings of the debit and credit charges appearing in the ledger which have been posted from the Work Reports and Day Book, and no others. This implies that neither the first nor the second inventories, nor the Balances of whatever description have been set forth in the Trial Balance. The object of taking it is not to determine Gain and Loss or Present Worth, but merely to determine whether the various items which orig. inated in the Day Book and the Work Reports have been accurately posted to the Ledger. If they have been, the debits and eredits balance.

Trial Balance

Cash

Bills Payable.

Contineent

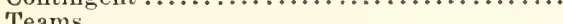

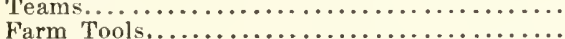

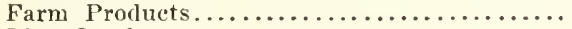

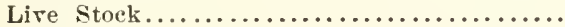

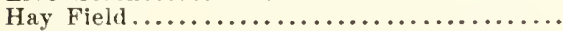

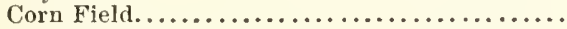

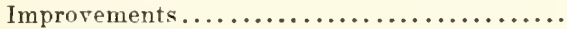

1900 Wheat Field.

1901 Wheat Field

Orchard ${ }^{2}$

Oat Field $\ldots \ldots \ldots \ldots \ldots \ldots \ldots \ldots \ldots \ldots \ldots$

Peter Brown.

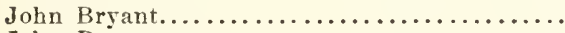

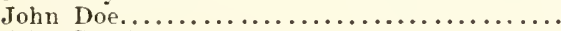

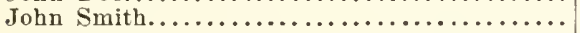

Dr. Cr.

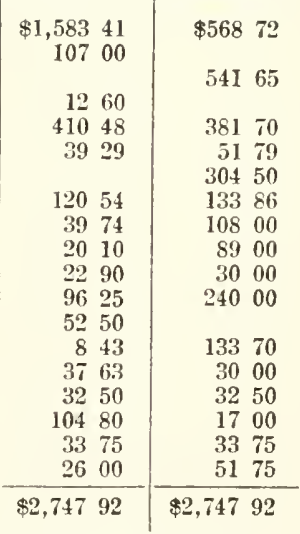


At the end of the year a new inventory is made. The live stock, teams and farm tools are valued as at first. The cash on hand is also set down. In this case it is taken from the books. Not knowing whether there eventually will be gain or loss in 1901 wheat field, the wheat is valued at cost, or what has been expended upon it, $\$ 52.50$. Mr. Bryant owes $\$ 87.80$, and there is $\$ 25.75$ due Mr. Smith. The former, for the present purpose, may be set down under the head of accounts due and the latter under accounts owing, although they are, strictly speaking, accounts with persons.

\section{Summary of Inventory taken May 1, 1901}

Teams. . ...................... \$810 00

Live Stock....................... 57000

Farm Tools ..................... 39600

Cash............................... 1,389 69

Value of wheat in ground............. 5250

Accounts Due (Bryant) ................ 8780

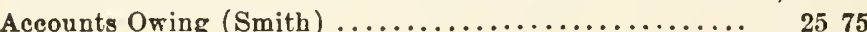

Net assets .................. \$3,280 24

The above summary sets forth in brief the assets and liabilities, and the net assets at the end of the year, which last can be quickly compared with the net assets at the beginning of the fiscal year. In this case, the assets are less at the beginning of the year than at its close; therefore the difference is gain: 


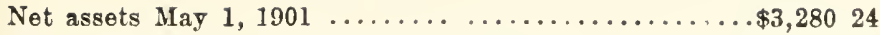

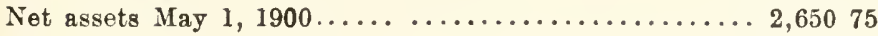

Gain............................ \$629 49

While this method of determining gain or loss is correct if all property of value is accurately set forth in the inventories taken at the beginning and end of the year, it does not reveal the detailed gains and losses of the various subdivisions into which the business has been divided.

After the inventory is taken, the amount (except Bills Payable) are entered on the credit side of Teams, Live Stock, Farm Tools, etc., and the accounts are balanced. The inventory value is then carried down to the opposite (debit) side of the new year's account and the "Balance," which shows either profit or loss in a property account, is transferred to a Gain and Loss account. If the balance is on the debit side it shows a profit and is entered on the credit side of the Gain and Loss account; if the balance is on the credit side of the property account it shows a loss and is transferred to the debit side of the Gain and Loss account. A red ink entry always means that the amount so written is to be transferred to the opposite side of some other account.

Having credited Teams, Live Stock and Farm Tools, respectively, with the amounts as found in the summary values, balanced the Cash account 
and credited 1901 Wheat Field with "wheat on the ground," \$52.50, and J. Bryant "by balance due," $\$ 87.80$, and balanced John Smith's account by entering on the debit side of it "to balance unpaid," $\$ 25.75$, we are ready to close all accounts and determine gain and loss in detail. All of these balances have been placed in bold-faced type, that the student may the better follow, step by step, the various operations necessary to balance and close the books.

The accounts are closed by entering either on the debit or credit side, as the case may be, the difference between them. To illustrate, the credit to Teams (p.62), including both inventory entries, exceeds the debits by $\$ 153.22$; therefore the following entry is made in the ledger, "To balance," $\$ 153.22$. Note just what the statement means and what it says - that in order to make the debit side of Teams account equal to the credit side $\$ 153.22$ has been arbitrarily entered. This amount did not come from the work report, nor the blotter, nor from any actual transaction, but was placed there for the single purpose of balancing the account with 'Teams. In like manner, enter such amounts as may be necessary in the other accounts to make their debits and credits equal, that is, balance. If the balance falls on the debit side it is written, "To balance," if on the credit side, "By balance." These entries are 
usually written in red ink, that they may be easily and quickly distinguished from entries which have been posted either from inventories, work reports or blotter.

The lines used when the accounts are closed should also be in red ink. Their number and position varies somewhat, but the common form is found in Teams account, the dotted lines being the ones which are usually in red ink.

The accounts being balanced and closed, they are now in the proper form for making a detailed statement of gain and loss, and also a statement of total net gain or loss. The gain and loss statement will require careful inspection by the student who is studying farm accounts without a teacher. Wherever an entry "To balance" is found there is profit; wherever "By balance" there is loss. It will be noticed that, in the cash account, the form is changed, and reads "By cash on hand." This really sets forth the fact that there is enough actual cash on hand to make the account balance. In the two personal accounts, the entries are "To" or "By" amount due to balance. In all three of these cases there is an actual valne equal to the difference between the debit and credit sides, therefore these accounts do not show either gain or loss. The gain and loss account of the sample ledger appears as follows: 
GAIN AND Loss

\begin{tabular}{|c|c|c|c|}
\hline 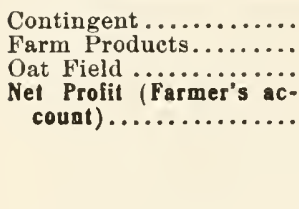 & $\begin{array}{r}\$ 1260 \\
1050 \\
763 \\
62949\end{array}$ & 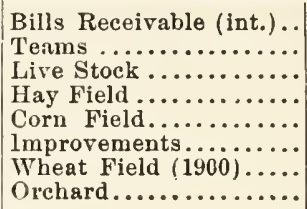 & $\begin{array}{rr}\$ 2 & 40 \\
153 & 22 \\
91 & 32 \\
68 & 26 \\
68 & 90 \\
7 & 10 \\
143 & 75 \\
125 & 27\end{array}$ \\
\hline & 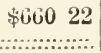 & & $\$ 6602$ \\
\hline
\end{tabular}

The accounts with Teams and Live Stock require only a little explanation. It may be said, however, that the last inventory is supposed to set forth not only the value of the animals on hand, but also a part of the value of some of the food that remains unused, which was charged up to these two accounts and credited to Hay Field, Corn Field and Oat Field. It usually transpires that some of the hay or grain which has been charged to Teams or Live Stock is yet on hand when the inventory is taken in the spring, in which case it is inventoried the same as the animals, and the value of such products is added to the value of the animals. It should be noticed, too, that at the beginning of the year the amount of the inventory of teams was entered as a debit charge against them; therefore, the sum total of the values on hand at the close of the year should be eredited to teams. All other accounts which have inventories should be treated in like manner. If hay, grain and the like have not been sold 
to teams or stock or in the market but are on hand when an inventory is taken, an account is opened with Farm Products, that the account with Hay Field, Oat Field and the like may receive due credit and be closed. The amount of such property on hand is inventoried at the market price at the time the accounting is made. This account of farm products is simply one of convenience. Incidentally it may show whether there has been gain or loss in holding that particular product for a higher price, in this case, wheat. As the products are sold from time to time, Farm Products receives credit and the person or personified account receiving value from farm products is debited. If sold for cash, Cash is debited and Farm Products credited.

The wheat held over (see pages 10, 47 (2), 49, 51 ), as usual, has fallen short in measure. It was inventoried at four hundred and twenty bushels, but had shrunk, when sold, to four hundred and ten, and although some of it was sold at a higher price than was placed upon it in the inventory, there was a loss of $\$ 10.50$ sustained over what would have been realized had it been sold on the day it was inventoried.

If the various cash transactions have all been correct there should be enough cash on hand to balance the account. If mistakes have been 
made in paying out eash or in receiving it, there would then appear to be either profit or loss. Suppose a two-dollar bill had been paid out for a one-dollar demand. Then the cash account would not balance, but show a loss of one dollar. If the mistake was reversed, then the account would show a gain of one dollar.

The debits and credits in the two personal accounts, Smith's and Bryant's, do not balance until an explanatory entry is made stating the difference. Since it is presupposed that Mr. Bryant will pay the $\$ 87.80$, and that we will pay Mr. Smith the $\$ 25.75$ we owe him, there is neither gain nor loss in these accounts.

The Improvement account shows a gain of $\$ 7.10$. It appears that enough wood has been sold to pay for a few improvements and leave a surplus of this amount. When the wood lot is small it is hardly necessary to open a separate account with it, but the receipts from wood or lumber may be used to reduce the debits which are certain to arise by reason of making ordinary repairs. If the wood lot is large and sales from it considerable, then a separate wood lot account should be kept. So, in like manner, a separate account should be opened if any expensive improvement is to be made, such as building a barn or house, that ordinary improvements and unusual improvements may be clearly separated 
and that the cost of the new buildings may be known.

Perhaps the most perplexing things to deal with in farm accounts are the straw and the barn manure. Let us try to follow the straw from the time the wheat is threshed until the beneficial fertilizing and mechanical effects of it are exhansted in the field after it has been passed through the stables and converted into manure. Let it be supposed that so much of the straw as is used by the teams is charged to them and credited to Wheat Field. The solid and liquid voidings are incorporated with the straw-bedding, and the resultant manure is more valuable than the straw was before it passed through the stables. Then it would only be just to the Teams account to credit it with something to represent the value of the excrements of the horses. If this is done an account must be opened with Manures, and this account debited and Teams credited with the value of the manure. When the manure is drawn to the field designed for corn, the Manure account must be credited and Corn Field debited with not only the value of the manure, but the cost of hauling it. But it is estimated that the first crop after manuring does not use more than one-half of the valuable constitnents of the manure applied. Then to be just to the corn field it should be credited with one- 
half of the original value of the manure and onehalf of the cost of hauling it. If this is done, some account must be debited with a like amount. Suppose barley follows the corn. Then Barley Field must be debited with an amount equal to the credit of Corn Field. But there will be an unused residue of the manure after the barley has been harvested,- how much it is impossible to estimate. If wheat follows the barley, then, it will receive some benefit from the manure that was put on the corn ground, and even the grass and clover which follow the wheat will be the better because the corn ground was treated with this dressing of manure. Sir J. B. Lawes found that liberal dressings of manure produced beneficial effects for many years after their application. It is evidently impracticable to follow one or a hundred loads of manure through this labyrinth of debit and credit. Quite as accurate data will be secured if no credit is given to Wheat Field for the straw unless it is sold in the market. This would obviate making any debit or credit charges for the straw used on the farm, in which case all of the accounts could be closed at the end of the year and gain and loss approximately determined. We would better leave these changing values to the good judgment of the farmer at the end of the year.

The expense of hauling the manure falls most 
naturally under Improvement account. At the end of the year this account will usually show that more has been paid out than has been received, unless there is timber, stone or cord wood to sell. But suppose it is so. After the accounts are closed and gain and loss determined, it will not be difficult for the proprietor to inspect the gain and loss statement, and, being conversant with all the facts, he will be able to determine approximately the true amount of gain or loss.

When the Trial Balance has been completed and proved, the farmer may east up his assets and liabilities in the following form:

Assets-

\section{Balance Sheet}

Cash ...................... $\$ 1,38969$

Teams....................... 81000

Farm Tools.................... 39000

Live Stock...................... 57000

1901 Wheat Field............... 5250

John Bryant.................. $\quad 8780$

Liabilities-

John Smith.................... \$25 75

Farmer (Net Worth)............. 3,280 24 


\section{CHAPTER VI}

\section{ACCOUNTS WITH PARTICULAR FIELDS AND CROPS}

Two methods of determining gain or loss have already been set forth. The one simply attempts to note values of property possessed at the beginning and end of the year. The difference in these inventories shows the gross gain or loss, but from them it cannot be determined in what particular undertaking the gain or the loss occurred. The second method, which is more elaborate, sets forth as nearly as farm conditions will permit, the gain or loss in each subdivision. A banker may, and not infrequently does, estimate his securities at more than they are worth. That is, he inventories them at face value when they are really at a discount, or entirely valueless. In a similar way, a farmer may inventory a horse at $\$ 500$ when it really is worth only $\$ 150$, and will not sell for more than that. It will be seen that in order to determine gain or loss with any degree of accuracy not only must the accounts be kept correctly, but the best of judgment must be exercised in valuing the assets at the beginning and 
the end of the year. A study of the markets develops judgment as to values.

The third method of keeping accounts, described in the following pages, also requires good judgment and a clear understanding of values and of the business carried on. In this, as in the former methods, an inventory should be taken both at the beginning and the end of the year. Let it be supposed that there is doubt as to the relative profits of the wheat, oat and corn crops. The previous account shows large profit in raising wheat and loss in raising oats, and this is valuable information, but it may not be convenient for every one to keep as detailed accounts as are shown by the second method, Chapters II and III. So a modified method of accounting is presented below. If the first method be adopted there is no means of knowing the relative profits of the different crops or undertakings. This third method is an attempt to combine a part of the two methods already given in a simple and fairly accurate way, the purpose being to discover which of a few particular crops $\mathrm{ol}^{\circ}$ undertakings give best results.

Let it be supposed that it is desirable to learn the cost of producing a bushel of wheat, a bushel of corn and a bushel of oats. First, establish a fair wage for man and team, including use of tools, which will be simpler than to make a 
separate charge for their use at the end of the transaction. In many cases ten cents for man and fifteen cents for team per hour, including use of tools, will be approximately correct. Provide a few work reports (time books), and a few sheets of foolscap paper or a small blank book. At the close of each day, when the men and the teams have been engaged in the wheat, oat or corn fields, note on their respective work reports the actual number of hours devoted to each crop. In the blank book open three accounts, one with each crop, and debit them respectively with seed, commercial fertilizers, threshing bill and any other debit items which are not recorded in the work reports. For manures, see page 79. All of these accounts may be kept in single-entry form.

When the grain is threshed, or the crop is in such form that a price can be placed on the harvested crop, put a just value on such products and from such value deduct the cost as determined by the sum totals of the entries in the work reports and blotter. If the value of each crop exceeds the debtor charges against it, the difference will represent the value of the use of the land and profits. When the value is subtracted from the debtor charges, the profits will be shown. We may now, also, compare the profits as between the different kinds of crops with which accounts have been kept. 


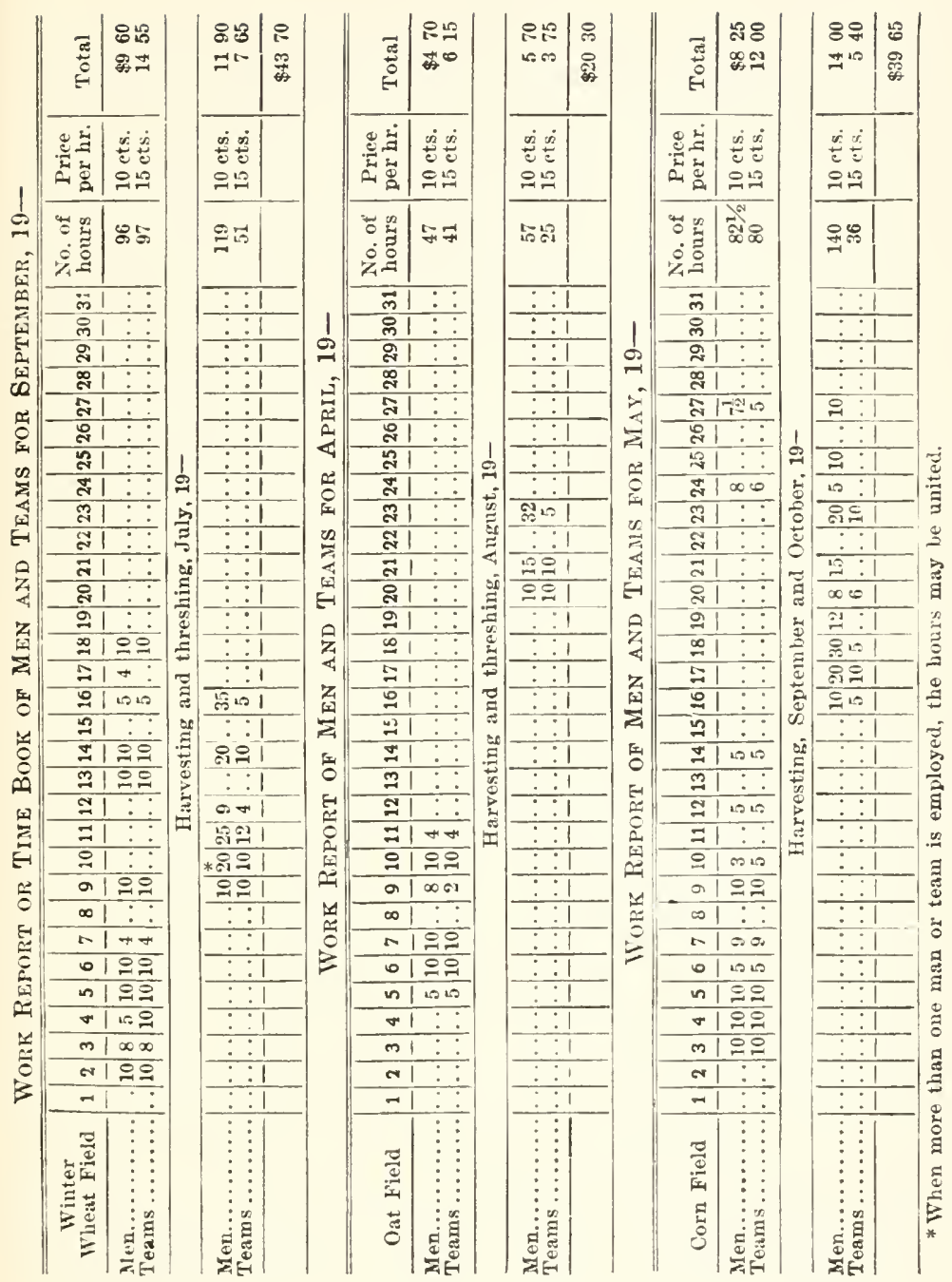




\section{BLOTTER}

\begin{tabular}{|c|c|c|c|}
\hline Sept. & 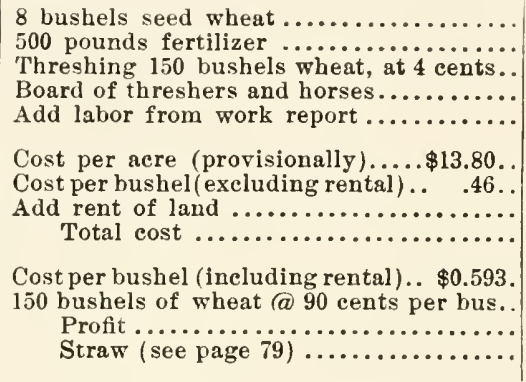 & $\begin{array}{rl}\$ 8 & 00 \\
8 & 80 \\
6 & 00 \\
2 & 50 \\
43 & 70\end{array}$ & $\begin{array}{r}\$ 6900 \\
8900\end{array}$ \\
\hline
\end{tabular}

No account has been taken of the value of the straw in this case. It might well offset the value of the barn manures applied, or the value might be added to the profits of the grain, as it has been in the corn field.

1901

OAt Field - Five Acres

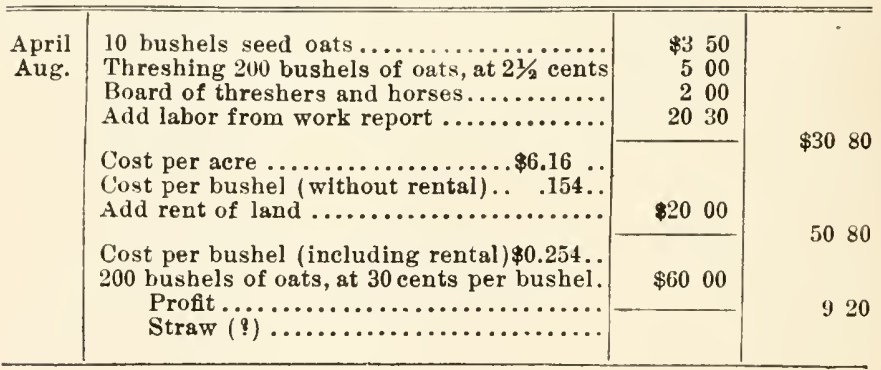




\begin{tabular}{|c|c|c|c|}
\hline \multirow[t]{4}{*}{ May } & $\begin{array}{l}\text { I bushel seed corn. } \ldots \ldots \ldots \ldots \ldots \ldots \ldots \\
\text { Add labor from work report } \ldots \ldots \ldots \ldots \ldots\end{array}$ & $\begin{array}{ll}\$ 1 & 00 \\
39 & 65\end{array}$ & \multirow{3}{*}{$\begin{array}{l}\$ 4065 \\
6065\end{array}$} \\
\hline & 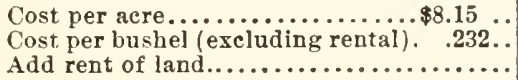 & $\$ 2000$ & \\
\hline & $\begin{array}{l}\text { Cost per bushel (ineluding rental) } \$ 0.303 \ldots \\
200 \text { bushels of corn, at } 35 \text { cents per bushel. } \\
8 \text { tons of stalks, at } \$ 4 \text { perton............ }\end{array}$ & $\begin{array}{rl}\$ 70 & 00 \\
32 & 00\end{array}$ & \\
\hline & 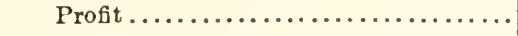 & & 4135 \\
\hline
\end{tabular}

It will be seen by the above accounts that five acres, when used for growing oats, produced less profit than five acres used for growing either wheat or corn. Another year the oat field might make a better showing; therefore accounts should be kept for several consecutive years, until the average relative gain and loss is definitely determined. Account may be taken of straw and stover, because these coarse products have some value in all sections of the country. In the accounts with wheat and oat field, no credit has been given for straw, while in the account with corn field the stover has been credited. If the straw is credited, it will reduce the cost per bushel of the wheat and oats. As has been said before, sometimes the straw is offset against the barn manures which have been applied, and not infrequently this is the simplest way to avoid uncertain estimates - that of the value of straw 
and the cost and value of manures applied. Whatever way this subject is treated there are enough factors revealed in the accounts to clear the understanding, improve the judgment and lead to such changes as are likely to result in more libera! reward.

\section{ACCOUNTS WITH GREENHOUSES}

Accounts should not only be kept by farmers with the various crops raised and the several classes of animals reared, but men engaged in floriculture and fruit-growing should determine which of the various minor undertakings produces profit and which produces loss.

The horticulturist may estimate, with some degree of accuracy, the total profits or losses at the end of the year, if he has had enterprise enough to value the plant at the beginning and end of the year, and has taken account of the depreciation, and has included cash on hand and bills receivable and bills payable. But all this will give no data by which the profits or losses of any particular branch of his undertaking may be determined. One forcing-house in which a certain class of plants is raised may be yielding a hundred per cent profit, while another results in a loss of twenty-five per cent. In the dairy, it is often found that one-half the cows are kept at a satisfactory profit, one-fourth simply pay 
for board and eare, while one-fourth are kept at, a ruinous loss. In horticulture, similar conditions are always present, and the losses cannot be surely stopped nor the gains increased most economically unless accounts are kept somewhat in detail with the various kinds or groups of plants.

Before proceeding to details, it may be said that too much bookkeeping should not be undertaken at first. Take a single forcing-house or greenhouse to start with, and, as the judgment develops and the art of keeping accounts is mastered, open accounts with other branches of the business, and finally the gains or losses of each subdivision of the business, as well as the total profits or losses, will be revealed.

Enough has been said in previous chapters respecting the necessity of keeping oneself fully and promptly informed as to the financial success or failure of the business as a whole, or any branch thereof, and as to the educational value of accounts; therefore, we may, without further discussion, outline a plan for keeping simple accounts with one forcing-house, or more, in which lettuce is grown in the fall and winter, and cucumbers in the spring.

A good time to take the inventory and begin these accounts is about September 1, although this should be governed by climatic conditions and the 
markets. First, value the house; second, the tools and equipment; third, the heater, if the house has a separate one. All this will be charged on the debit side of the account when first opened. If the house is one of several which are warned from a common plant, then inventory the heating plant with its equipment, and also the coal on hand, if any, and open a separate account with the heating plant. As the year goes on, this inventory will be followed by debit items which will set forth fully the cost of coal, labor and sundries. At the end of the year, the heating plant is again valued, and the amount placed on the credit side of the account. The difference ketween the debit and credit sides will show the cost of the heating for the year. Then an estimate is made of the number of square feet of glass in the various houses. Knowing this, the accountant will be able to charge to the one house with which accounts are being kept the just proportion of the cost of heating all the houses. It will be seen that in this case accounts must not only be kept with the forcinghouse proper, but with the heating plant as well. In any case, it is a good plan to determine the cost of the heating for either one house or all the houses, because it is a start toward learning the financial end of the business. When the total cost of heating an establishment 
is recorded in cold figures, effort is likely to be made to reduce such cost, whereas, if nothing is known as to the expense of running the heater, the highest economy is not likely to be practiced. The house, of course, will have to be debited not only with the cost of the heating, but with seed, labor and tools, if any are supplied. The daybook should be a real day-book, and not a weekbook; that is, all debits and credits should be entered on the day on which they occur. The accounts should be posted to the ledger as often as once a month. Once a week is better.

The accounts that are posted in the ledger come from two sources: the day-book, and the work riports. As the work reports have been fully explained in a previous chapter, it will not be necessary to explain them again. It should be observed, however, that, if the attendant in the forcing-house takes care of more than one house, or does other work, the work reports should show not only the time occupied in the house with which the account is kept but the time spent elsewhere, although only the time spent in the one house is posted to the ledger. It requires but little care for the workman to observe the number of hours spent in any particular house or houses, and the time spent elsewhere, of which no permanent record is made.

Before giving a hypothetical debit and credit 
Dr.

\begin{tabular}{|c|c|c|c|c|}
\hline Sept. & 1 & To value of forcing-house...... & $\$ 1,00000$ & \\
\hline & 1 & 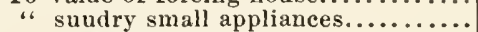 & 800 & \\
\hline “. & 6 & $" 2$ pails (D. B.).............. & 100 & \\
\hline “، & 6 & " 50 feet of hose (D. B.).......... & 750 & \\
\hline “4 & 6 & " 30 hours of labor at $15 \mathrm{ets}$. (W. R.) & 450 & \\
\hline Oet. & 2 & $\begin{array}{l}\text { fertilizers and prepared earth } \\
(D, B .) \ldots \ldots \ldots \ldots \ldots \ldots \ldots \ldots \ldots \ldots\end{array}$ & 1000 & \\
\hline "، & 2 & " 40 hours' labor at 15 ets. (W. R.)... & 600 & \\
\hline Nov. & 5 & $\begin{array}{l}\text { fumigating material and apparatus } \\
(\text { D. B. }) \ldots \ldots \ldots \ldots \ldots \ldots \ldots \ldots \ldots\end{array}$ & 500 & \\
\hline ." & 30 & $" 70$ hours' labor at $15 \mathrm{ets} . . . . . . .$. & 1050 & \\
\hline $\begin{array}{l}\text { Dec. } \\
\quad 1904\end{array}$ & & " 81 lours' labor at $15 \mathrm{ets}$ ( (W. R.).. & 1260 & \\
\hline Jan. & 5 & " insurance for one year (D. B.).... & 1500 & \\
\hline 4 & 31 & " 100 hours' labor at 15 ets. (W.R.). & 1500 & \\
\hline Feb. & 6 & " sundry small supplies (D. B.)..... & 580 & \\
\hline & 6 & “ replacing glass (D. B.) .......... & 425 & \\
\hline ، & 28 & " 96 hours' labor at 15 ets. (W. R.).. & 1440 & \\
\hline March & 31 & " 104 hours' labor at 15 cts......... & 1560 & \\
\hline April & 30 & “ 92 hours' labor at 15 cts. (W. R.).. & 1380 & \\
\hline May & 31 & " 80 hours' labor at $15 \mathrm{cts}$ ( (W. R.).. & 1200 & \\
\hline June & 30 & " 74 hours' labor at 15 ets. (W. R.).. & 1110 & \\
\hline July & 31 & " 60 hours' labor at $15 \mathrm{cts}$ (W. R.).. & 900 & \\
\hline$\because$ & 31 & " bill for packing boxes (D. B.).... & 2100 & \\
\hline \multirow{4}{*}{ Aug. } & 31 & " 76 hours" labor, painting,ete.(W.R.) & 1140 & \\
\hline & 31 & " cost of heating (D. B.)............ & 6500 & \multirow{2}{*}{$\begin{array}{rl}\$ 1,278 & 45 \\
357 & 35\end{array}$} \\
\hline & & \multirow[t]{2}{*}{ Profit and loss to balance.......... } & & \\
\hline & & & & $\$ 1,63580$ \\
\hline
\end{tabular}

ledger account, I wish to emphasize the desirablity of keeping the day-book or blotter in such a way and so fully that each item may be identified accurately when posted to the ledger, where, of course, the items may be abbreviated.

In the ledger account, note that some of the charges come from the day-book (D. B.), some from the work reports (W.R.), and some from the 
Cr.

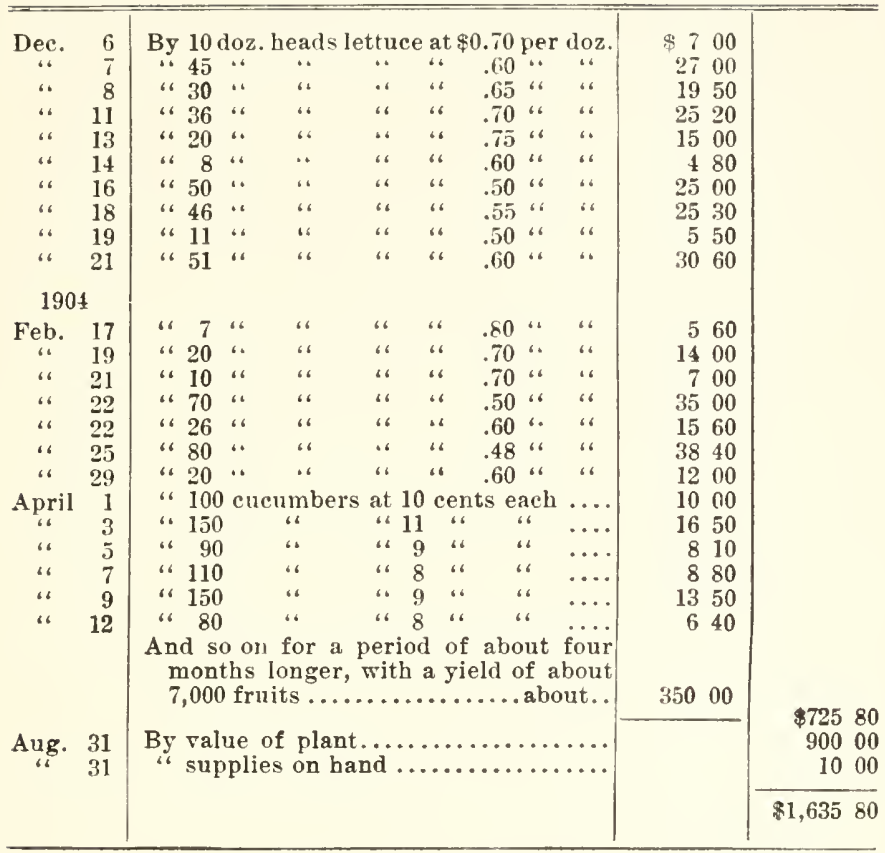

inventories made at the beginning and end of the year. The last inventory is placed on the credit side of the account and should be the last entry, unless the credits are less than the debits, in which case "profit and loss to balance" would be the last entry, as it is the last entry on the debit side of the present account, because the credits exceed the debits, - that is, there has been less 
paid out by $\$ 357.35$ than has been received; hence that amount is entered on the debit side to balance.

In opening the account with house No. 1, at the beginning of the second fiscal year, the first debit charge would be "to value of plant, $\$ 900$," followed by "supplies on hand, $\$ 10$."

It may be said that the profit, $\$ 357.35$, as shown on page 92 , is not very large, but that is not the point. The accounts, as set forth, are to illustrate how accounts may be kept easily and accurately by an untrained bookkeeper. If there are children in the family, of suitable age, they should be required to keep the accounts, subject to the supervision of father or mother.

\section{ACCOUNT WITH A TEN-ACRE APPLE ORCHARD}

I am certain that it would be both pleasant and valuable if the cost of raising an orchard up to the age of profitable fruitfulness could be known. It is here assumed that after apple trees have been set about eight years they will produce such an amount of fruit as will pay for care of trees and soil and for harvesting and marketing, and leave a surplus for interest on investment and a small profit the ninth year, with steadily increasing profit thereafter until the trees begin to fail by reason of age. Therefore, the account is closed at the end of eight years, at which time the cost 
of the orcharl, in this instance, has been $\$ 1,278.16$, or $\$ 127.82$ per acre, including the land, or $\$ 77.82$ per acre for the trees, tillage, etc. over and above the cost of the land. The cost of the crops planted in the intervals and the amount received for them is separated from the investment account. Here again it should be remembered that a real account may not, and probably will not, exactly duplicate a single item given in the account set forth below; but this account explains the method.

The ledger account is kept in a somewhat different form from the accounts in a previous chapter, and from that for the forcing-house. Really two accounts are carried on the debit side of the ledger, one with the interval or harvest crop, and one with orchard proper, or with the realty. At the end of each year the profit or loss of the interval crop is easily ascertainable, and also the amount invested in land and trees, that is, in the realty. The day-book, the work reports and the ledger would in practice show more items than are set forth on the debit side and far more than are recorded on the credit side. A single year would probably require more space in the ledger than is here given to the eight years.

It will be noted that the fertilizers are charged to the harvest or interval crop and the seeds 
and sowing of the cover-crop to the investment account, in the second column. This may not be a perfect division of the expenses incurred for maintaining the fertility of the orchard and for producing the interval crop, but if one-half of the expense of fertilizers and cover-crops be charged to interval crop and one-half to investment, it will complicate the accounts and probably be no more accurate.

In the account with the foreing-house and with the orchard it may be most convenient to record all the accounts, except the labor account, daily in the ledger, thus avoiding posting. At the end of the month the work report or reports are footed and the amounts posted to the ledger on the debit side. By this method the day-book is dispensed with. The ledger, to all intents and purposes, becomes the journal. In the accounts set forth in the preceding chapters the journal has been dispensed with; here we dispense with both ledger and day-book. At the end of each month the debits and credits should be added and the totals placed at the foot of the columns. This will show, month by month, the amount of the running expenses and the income, and give timely and valuable information as to the monthly financial standing of the undertaking. In these tentative accounts it may be more convenient for the farmer to keep single-entry than double-entry. 
It will be noticed that the credits of the harvest crop are less than the debits by $\$ 30.50$. If this loss on harvest crops should be great, the amount of such loss should be added to the cost of raising the orchard. In this case the harvest crop so nearly balances that it seems unnecessary to carry it to the or'chard or investment account. However, it is readily seen that if it were carried to that account it would increase the cost of the orchard $\$ 3.05$ per acre.

Having found the total cost of maintaining the orchard, the cost per tree can be easily found. If there are one hundred Greenings, eighty Baldwins and seventy Northern Spys, the relative profits of each variety can also be found by noting the amounts received for the several varieties of fruit and striking a balance between these receipts and the expenditures for maintenance. With a little additional attention not only the relative profits of the separate varieties to the orchard as a whole, but also the profit of each tree, can be determined. It is assumed that the cost of maintenance for each variety and each tree is proportionally the same. If accounts were kept in detail with a few orchards in a locality, the best commercial variety for that locality would be revealed beyond a doubt; and, what would be of more value, there would be substitution of facts for guess-work. 
ORCHARD Dr. Harvest crop Orchard

\begin{tabular}{|c|c|c|c|}
\hline Sept. 1 & 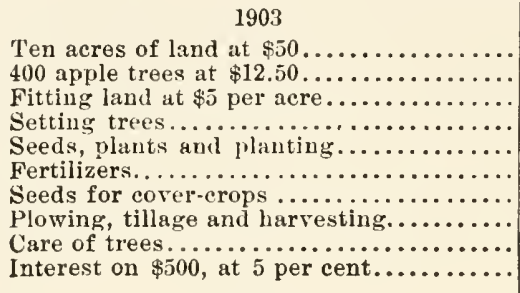 & $\begin{array}{r}\$ 3000 \\
2000 \\
5000\end{array}$ & $\begin{array}{rl}\$ 500 & 00 \\
50 & 00 \\
50 & 00 \\
25 & 00\end{array}$ \\
\hline Sept. 1 & 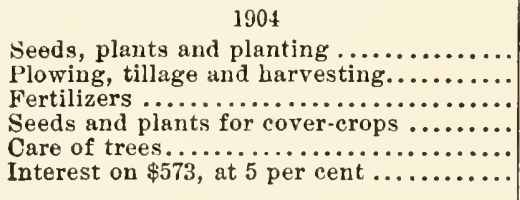 & $\begin{array}{rl}\$ 100 & 00 \\
30 & 00 \\
50 & 00 \\
20 & 00\end{array}$ & $\begin{array}{ll}12 & 00 \\
14 & 00 \\
28 & 65\end{array}$ \\
\hline Sept. 1 & 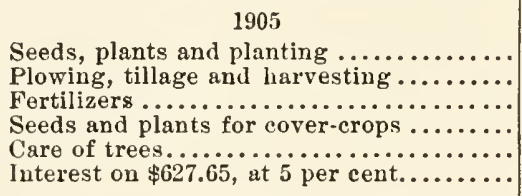 & $\begin{array}{r}\$ 20000 \\
2500 \\
5500 \\
2000\end{array}$ & $\begin{array}{ll}13 & 00 \\
15 & 00 \\
31 & 38\end{array}$ \\
\hline Sept. 1 & 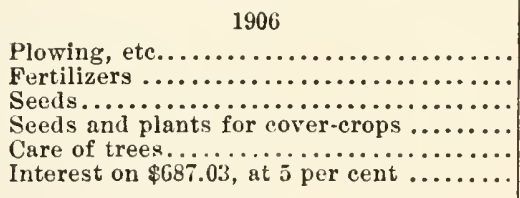 & $\begin{array}{rr}\$ 300 & 00 \\
24 & 00 \\
54 & 50 \\
26 & 00\end{array}$ & $\begin{array}{ll}18 & 00 \\
16 & 50 \\
34 & 35\end{array}$ \\
\hline Sept. 1 & 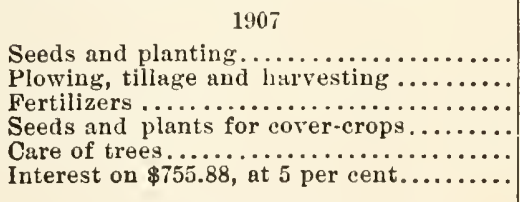 & $\begin{array}{rr}\$ 404 & 50 \\
22 & 00 \\
51 & 00 \\
32 & 00\end{array}$ & $\begin{array}{ll}25 & 00 \\
20 & 00 \\
37 & 79 \\
\end{array}$ \\
\hline & Amount carried forward & $\$ 50950$ & $\$ 96867$ \\
\hline
\end{tabular}


Dr. Harvest Crop Orchara

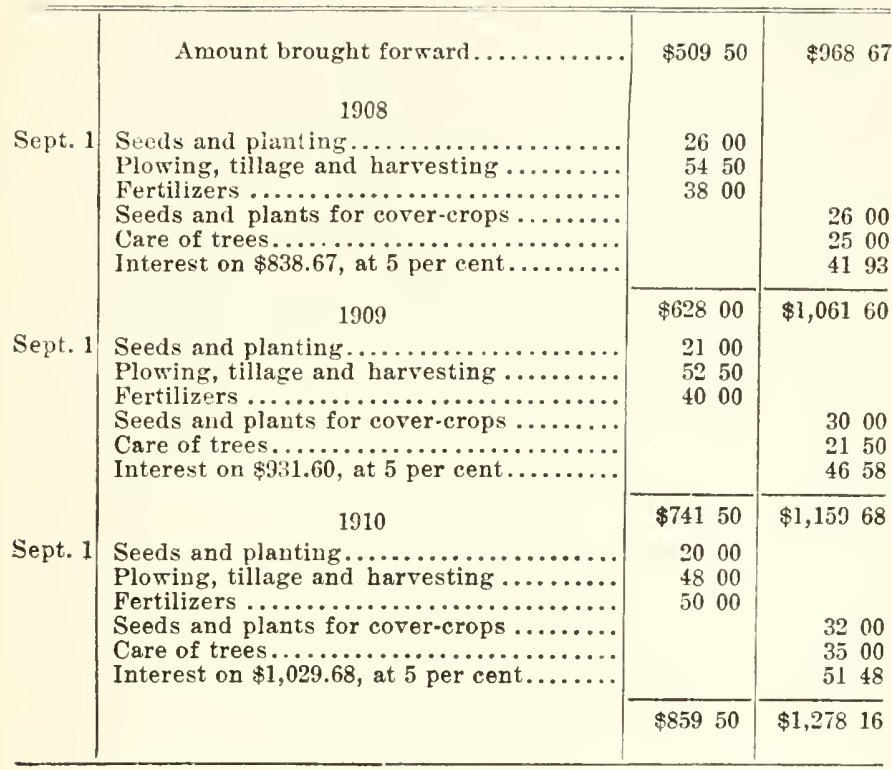




\begin{tabular}{|c|c|c|c|c|}
\hline & & & ORCHARD & Harvest crop \\
\hline & & & 1903 & \\
\hline $\begin{array}{l}\text { Aug. } \\
\text { Sept. }\end{array}$ & & 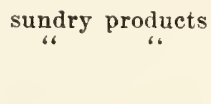 & $\begin{array}{l}\ldots \ldots \ldots \ldots \ldots \cdots \cdots \\
1904\end{array}$ & $\begin{array}{l}\$ 1000 \\
11500\end{array}$ \\
\hline $\begin{array}{l}\text { June } \\
\text { Sept. }\end{array}$ & & sundry products & $\begin{array}{l}\ldots \ldots \ldots \ldots \ldots \ldots \ldots \ldots \ldots \ldots \ldots \\
1905\end{array}$ & $\begin{array}{ll}25 & 00 \\
96 & 00\end{array}$ \\
\hline $\begin{array}{l}\text { June } \\
\text { Oct. }\end{array}$ & By & sundry products & 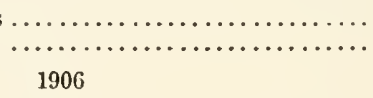 & $\begin{array}{ll}25 & 00 \\
90 & 00\end{array}$ \\
\hline July & $\mathrm{By}$ & sundry products & ${ }^{\prime} \ldots \ldots \ldots \ldots \ldots \ldots \ldots \ldots$ & 1500 \\
\hline Aug. & & $\because 40$ & 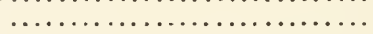 & 2800 \\
\hline Oct. & & “ & ${ }_{1907}$ & 7600 \\
\hline $\begin{array}{l}\text { July } \\
\text { Sept. }\end{array}$ & By & sundry products & $\begin{array}{c}\ldots \ldots \ldots \\
1908\end{array}$ & $\begin{array}{ll}40 & 00 \\
80 & 00\end{array}$ \\
\hline $\begin{array}{l}\text { June } \\
\text { Oct. }\end{array}$ & & sundry products & 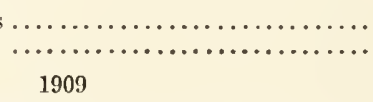 & $\begin{array}{ll}32 & 00 \\
66 & 00\end{array}$ \\
\hline $\begin{array}{l}\text { July } \\
\text { Sept. }\end{array}$ & & sundry products & $\begin{array}{l}\ldots \ldots \ldots \ldots \ldots \cdots \cdots \\
1910\end{array}$ & $\begin{array}{ll}25 & 00 \\
60 & 00\end{array}$ \\
\hline $\begin{array}{l}\text { June } \\
\text { July } \\
\text { Aug. } \\
\text { Sept. }\end{array}$ & $\begin{array}{l}\text { By } \\
\text { "6 } \\
\text { " }\end{array}$ & $\begin{array}{cc}\text { sundry } & \text { products } \\
16 & 6 \\
" 6 & 6\end{array}$ & 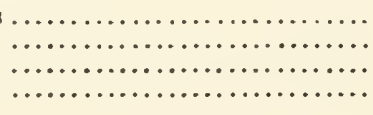 & $\begin{array}{rl}10 & 00 \\
5 & 00 \\
16 & 00 \\
15 & 00 \\
\end{array}$ \\
\hline \multirow{2}{*}{ Sept. } & \multirow{2}{*}{\multicolumn{3}{|c|}{ 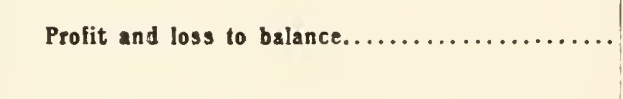 }} & $\begin{array}{rl}\$ 829 & 00 \\
3050\end{array}$ \\
\hline & & & & $\$ 85950$ \\
\hline
\end{tabular}




\section{CHAPTER VII}

\section{ACCOUNTS WITH ANIMALS}

IT is difficult to keep a complete book account with animals, because there are so many fluctuating, indefinite and unpredictable factor's concerned in the feeding of the animal, in its products and in its chances of longevity. However, experience has enabled us to reduce some of these items to fairly uniform rules of practice. It is hoped that the following advice is definite enough to be useful to the careful farmer.

\section{MILK ACCOUNTS}

The following form indicates how the daily yield of milk may be recorded accurately and quickly. It is a copy of an actual record of an entire mixed herd of cows of all ages and in all stages of lactation, mostly far advanced in the milk period. A spring balance, which can be quickly adjusted so as to eliminate the tare or weight of the pail, hangs near the place where the milk is to be strained and recorded. Care is taken to have the pails uniform in weight. The 
weight of the heaviest one is determined, and then the lighter ones are brought up to this weight by attaching small masses of solder to the bottoms, also protecting them from wear. It is not unusual to find that one cow is producing twice as much milk as another in the same herd and, while the former may consume more food than the latter, the care-taker knows, now that he has taken account of the respective yearly production of the cows, that the one is profitable and that the other is kept at a loss; although, without weighing the food consumed and determining the total butter-fats, he may not be able to determine the exact profits arising from the one or the losses from the other. The care-taker's judgment cannot be trusted as to the total yearly production of each cow in the herd. He must weigh and record the milk before he begins that never-to-be-neglected yearly process of "weeding-out." If the herd is to be improved rapidly, not only should the daily and yearly production of milk of each cow be known, but the yearly production of butter-fats, and, approximately, the amount and cost of each cow's food.

To the dairyman who lays great stress on pushing his work, and who tries to get on with the fewest possible workmen, the daily weighing and recording of each cow's food appears to be not 
only a great task, but time thrown away. But, if the weeding out is to be done intelligently there is no other way except to keep an account with each cow. The weighing of the grain or meal ration takes but little time. The weighing of the hay is somewhat more difficult. However, if suitable appliances are at hand (see p. 110) a workman will weigh the grain and hay for a herd of twenty cows in one-half hour, or at a cost of $\$ 10$ for two hundred days. The information secured would be likely to result in saving this amount in the discarding of one umprofitable cow.

DAILF Milk Report For July 2, 1901

Pounds and tenth-pounds

\begin{tabular}{|c|c|c|c|c|c|c|c|}
\hline Name & Morn. & Even. & Total & Name & Moru. & Even. & Total \\
\hline Ada. & & & & $\begin{array}{l}\text { Brought } \\
\text { forw'd }\end{array}$ & 135 & 115 & 250 \\
\hline Belle..... & $\ddot{11.0}$ & $\ddot{8.6}$ & 20.3 & Kate..... & ........ & $\ldots \ldots$ & ......... \\
\hline Belva..... & $\ldots \ldots$ & & & Mabel... & $\ldots \ldots \ldots$ & $\ldots$ & $\ldots$ \\
\hline Bertha ... & 11.4 & 10 & 21.4 & Marge... & & & \\
\hline Celia..... & 4.5 & 5 & 9.5 & Mav..... & 13 & 13.5 & 26.5 \\
\hline Chloe..... & 9.4 & 7.8 & 17.2 & Meda.... & & & \\
\hline Clover... & 13.2 & 6.9 & 20.1 & Mona.... & 9 & 8.9 & 17.9 \\
\hline Dena..... & 12.2 & 10.6 & 22.8 & Nina.... & $\ldots \ldots \ldots$ & $\ldots \ldots$ & $\ldots \ldots$ \\
\hline Dinah.... & 9.3 & 9 & 18.3 & Pansy ... & ....... & & \\
\hline Dixie.... & 5.3 & 5.5 & 10.8 & Patty.... & 15.9 & 15.3 & $\ddot{31.2}$ \\
\hline Dove....... & 7.8 & 7.4 & 15.2 & Peach ... & 11.5 & 10.7 & 22.2 \\
\hline Eva...... & $\ldots \ldots \ldots$ & $\ldots \ldots$ & $\ldots \ldots$ & Polly ... & 12.7 & 12 & 24.7 \\
\hline Fan ....... & ......... & 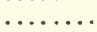 & ...... & Rena..... & 19.2 & 15.1 & 34.3 \\
\hline lreda..... & $\ldots$ & & & Rita..... & 15 & 13 & 28 \\
\hline Garnet.... & 14.4 & 10.5 & 24.9 & Rose.... & 9.5 & 9 & 18.5 \\
\hline Gloria.... & & & & Sara..... & & & \\
\hline 111lda..... & 11.3 & 11.5 & 22.8 & Stella.... & 10.4 & 13.3 & 23.7 \\
\hline Ida....... & 12 & 10.2 & 22.2 & Tilda ... & 15 & 12.3 & 27.3 \\
\hline . Iennie.... & $\ldots$ & & & Tina..... & 11.8 & ] 0.1 & 21.9 \\
\hline \multirow{2}{*}{$\begin{array}{r}\text { Jalia ...... } \\
\text { forw'd }\end{array}$} & 12.5 & 19 & 24.5 & \multirow[b]{2}{*}{$\begin{array}{r}\text { Total for } \\
\text { the day }\end{array}$} & \multirow[b]{2}{*}{278} & \multirow[b]{2}{*}{248} & \multirow[b]{2}{*}{526.2} \\
\hline & 135 & 115 & 250 & & & & \\
\hline
\end{tabular}


Milk Report for the Week Beginning July 2, 1902

Pounds and tenth-pounds

\begin{tabular}{|c|c|c|c|c|c|c|c|c|c|}
\hline Name & Sun. & Mon. & Tues. & Wed. & Thur. & Fri. & Sat. & \multicolumn{2}{|c|}{ Totals } \\
\hline Ada.. $\left\{\begin{array}{l}\text { A.M. } \\
\text { P.M. }\end{array}\right.$ & $\begin{array}{l}11.7 \\
10.2\end{array}$ & $\begin{array}{r}11.6 \\
9.8\end{array}$ & $\begin{array}{r}12 \\
8.7\end{array}$ & $\begin{array}{c}11.4 \\
9\end{array}$ & $\begin{array}{r}11.2 \\
9.4\end{array}$ & $\begin{array}{r}11.4 \\
9.2\end{array}$ & $\begin{array}{r}11.6 \\
9.1\end{array}$ & $\begin{array}{l}80.9 \\
65.4\end{array}$ & \\
\hline Belva. $\left\{\begin{array}{l}\text { A.s. } \\
\text { Р.M. }\end{array}\right.$ & $\cdots \cdots \cdots$ & $\cdots \cdots$ & $\cdots \cdots$ & an. & $\cdots \cdots \cdots$ & $\cdots \cdots \cdots$ & $\cdots \cdots \cdots$ & $\cdots \cdots$ & \\
\hline Clover $\left\{\begin{array}{l}\text { A.M. } \\
\text { P.M. }\end{array}\right.$ & $\begin{array}{r}13.2 \\
7.4\end{array}$ & $\begin{array}{r}12.8 \\
7.5\end{array}$ & $\begin{array}{c}13.6 \\
8\end{array}$ & $\begin{array}{r}13.4 \\
6.9\end{array}$ & $\begin{array}{r}12.7 \\
7.7\end{array}$ & $\begin{array}{r}13.3 \\
8.2\end{array}$ & $\begin{array}{l}13 \\
6.8\end{array}$ & $\begin{array}{l}92 \\
52.5\end{array}$ & \\
\hline Dinah $\left\{\begin{array}{l}\text { A.M. } \\
\text { P.M. }\end{array}\right.$ & $\cdots \cdots$ & $\cdots \cdots$ & $\cdots \cdots \cdot$ & $\begin{array}{l}9.3 \\
9\end{array}$ & $\begin{array}{l}9.5 \\
7.3\end{array}$ & $\begin{array}{l}9.2 \\
8\end{array}$ & $\begin{array}{l}8.9 \\
7.7\end{array}$ & $\begin{array}{l}36.9 \\
32\end{array}$ & \\
\hline Fan... $\left\{\begin{array}{l}\text { A.M. } \\
\text { P.M. }\end{array}\right.$ & $\cdots \cdots$ & & $\cdots \cdots$ & & & …… & $\cdots \cdots$ & $\cdots \cdots$ & \\
\hline Hilda. $\left\{\begin{array}{l}\text { A.M. } \\
\text { P.M. }\end{array}\right.$ & $\begin{array}{l}11.3 \\
10.6\end{array}$ & $\begin{array}{l}11.5 \\
10.8\end{array}$ & $\begin{array}{l}12 \\
10\end{array}$ & $\begin{array}{l}11.8 \\
11.2\end{array}$ & $\begin{array}{l}12.2 \\
10.7\end{array}$ & $\begin{array}{l}11.9 \\
11\end{array}$ & $\begin{array}{l}11.8 \\
11.3\end{array}$ & $\begin{array}{l}82.5 \\
75.6\end{array}$ & \\
\hline Ida... $\left\{\begin{array}{l}\text { A.M. } \\
\text { P.M. }\end{array}\right.$ & $\begin{array}{l}12 \\
10.2\end{array}$ & $\begin{array}{r}12.4 \\
9.6\end{array}$ & $\begin{array}{l}11.9 \\
10\end{array}$ & $\begin{array}{r}12.3 \\
9.8\end{array}$ & $\begin{array}{l}12.6 \\
10.3\end{array}$ & $\begin{array}{r}11.8 \\
9.3\end{array}$ & $\begin{array}{r}12.2 \\
9.9\end{array}$ & $\begin{array}{l}85.2 \\
69.1\end{array}$ & \\
\hline Julia.. $\left\{\begin{array}{l}\text { A.M. } \\
\text { P.M. }\end{array}\right.$ & $\begin{array}{l}12.5 \\
12\end{array}$ & $\begin{array}{l}11.9 \\
11.6\end{array}$ & $\begin{array}{l}12.2 \\
11.3\end{array}$ & $\begin{array}{l}12 \\
11.7\end{array}$ & $\begin{array}{l}12.4 \\
10.9\end{array}$ & $\begin{array}{l}12.6 \\
11.2\end{array}$ & $\begin{array}{l}11.8 \\
11.4\end{array}$ & $\begin{array}{l}85.4 \\
80.1\end{array}$ & \\
\hline May.. $\left\{\begin{array}{l}\text { A.M. } \\
\text { P.M. }\end{array}\right.$ & $\begin{array}{l}13 \\
13.6\end{array}$ & $\begin{array}{l}13.5 \\
12.7\end{array}$ & $\begin{array}{l}12.9 \\
13.1\end{array}$ & $\begin{array}{l}13.2 \\
13\end{array}$ & $\begin{array}{l}12.8 \\
12.7\end{array}$ & $\begin{array}{l}13.4 \\
13.2\end{array}$ & $\begin{array}{l}12.9 \\
12.8\end{array}$ & $\begin{array}{l}91.7 \\
91.1\end{array}$ & \\
\hline Peach. $\left\{\begin{array}{l}\text { A.M. } \\
\text { P.M. }\end{array}\right.$ & $\begin{array}{l}11.5 \\
10.7\end{array}$ & $\begin{array}{l}11.8 \\
11\end{array}$ & $\begin{array}{l}11.2 \\
10.9\end{array}$ & $\begin{array}{l}12 \\
10.6\end{array}$ & $\begin{array}{l}11.6 \\
11.2\end{array}$ & $\begin{array}{l}11.4 \\
10.4\end{array}$ & $\begin{array}{l}12.2 \\
11.3\end{array}$ & $\begin{array}{l}81 . \overline{1} \\
76.1\end{array}$ & \\
\hline & 159.9 & 158.5 & 157.8 & 176.6 & 175.2 & 175.5 & 174.7 & & 1178.2 \\
\hline
\end{tabular}

If such records are made once a week or twice a month throughout the year, a fairly correct estimate of the annual yield of each cow may be secured. However, it is so little work to weigh every day's milk, and such a great satisfaction to know the exact amount produced, as. 
to justify the keeping of complete eccounts with each cow.

Just how much pains should be taken to determine not only the amount of milk produced, but the amount of food consumed and the amount of butter-fats produced by each cow depends on circumstances. It would not be expensive nor irksome during the winter to weigh, for one day or one week each month, the ration of each cow. If the milk is to be used for the manufacture of cheese or butter, then the total production of butter-fats of each cow should be ascertained, for without such knowledge the judgment is likely to be led astray if only quantity is considered. Since the butter-fats in milk indicate so nearly its true value, no account is usually taken of the slightly varying proportions of milk sugar and casein. When milk is produced for city consumption little attention is paid to the percentage of butter-fats provided it does not fall below 3 per cent, the minimum legal standard in New York. It is to be hoped that the day may not be far distant when both milk and cream will be sold in the eity, as well as to the butter factory, for what it is,-that is, at prices corresponding to the percentage of butter-fats which it contains, or, in other words, at prices corresponding to its value.

In large herds, the preceding form of record 
will be found to be better than one which provides for recording the yield of milk for a month or even a week. This record for the day can be removed, doubled up and placed in a locked box provided with a small opening in the lid. Once each week or month the daily records should be posted to the milk ledger, a double page of which, suitably ruled, should be devoted to each animal. This double page should contain the milk record, date of breeding, calves and their sex, what disposition is made of them, and the pedigree or history of the cow,-in brief, whether she has been raised or bought, is full-blood, or grade, or of unknown breeding.

The objection to a monthly milk record-sheet, if the herd is at all large, is that it is usually hung or nailed on the wall, often where the light is deficient. Of necessity, it is too large to be placed on a shelf near a window, as smaller daily record blanks can be. With the blank on the shelf, the figures can be recorded legibly. On the large monthly record-sheet, placed on the wall, it is difficult for the tyro to record plainly. Then, too, the record becomes blurred and soiled, and the record-sheet is too eumbersome for convenient filing. All original records should be preserved for at least one year. A weekly recordblank is given above, and serves well for small herds. On the first form is recorded the yield of 
each cow for but one day. The total record of each cow for the week should be placed in the right-hand column of the second form, and the total daily record of all cows at the bottom. For July 2, the first day on which the record begins, the yield of milk of the ten cows was 159.9 pounds, and the total yield of all the cows for the week, 1178.2 pounds, is placed at the lower right-hand corner. To change pounds into quarts multiply by .4649 . To change quarts into pounds multiply by 2.15 .

Milk that is rich in butter-fats is slightly lighter. than milk poor in butter-fats. "Heavy" cream is lighter than "light" cream. The term "heavy," as applied to cream, means that it is thick or contains a liberal amount of butter-fats. The designation is unfortunate, as to some the term "heavy" gives the impression that "rich" cream weighs more than poor or thin cream, whereas the richer the creain in butter-fats, the lighter it is.

Suspend in the stable a good spring balance, graduated to tenths of pounds. Many of these balances are so constructed that the index finger may be placed at 0 when the empty pail is hung on the hook, hence no tare will have to be taken out when the milk is weighed. This supposes that all of the milk pails are of equal weight. It is a good. plan to have a standard-weight 
pail. Choose one of the heaviest for the standard, and bring the lighter pails up to standard weight by having solder fastened to the bottom in three places, as already advised. This solder will serve as flat, miniature legs, and will prolong the life of the pail by protecting the outside of the bottom from wear when it comes in contact with the floor.

Balances similar to those described are used for weighing the daily food of each cow. The stable should be provided with at least two galvanized iron pails for weighing the concentrated foods. After the ration is weighed it can be emptied into a box placed in front of the manger ready at hand at the next feeding time. A standard for supporting the scales completes the outfit for handling and weighing the concentrated foods.

Near the hay-chute suspend the spring balances; these will also serve for weighing the hay. The illustration (page 110) shows a convenient appliance for confining the hay in small bundles. One soon learns to guess very closely when making up the bundle of ten to twelve pounds. The effort should be to make the bundle a little too heavy at first. If too heavy, when tested by the balances, as much is pulled from the bundle as will reduce it to the desired weight.

True, all this will add slightly to the cost of 
running the dairy, but the results will justify the expenditure. With the inventory, work reports, milk and food records, and judgment in estimating the value of the use of the plant, and the value of manure and bedding, the profit or loss can be determined with a good degree of accuracy.

The following statement of a dairy is taken from a high-class weekly paper :

\section{RECEIPTS}

Received for fat cows in $1901 \ldots \ldots \ldots \ldots \ldots$.... \$86900

Received for fat calves in $1901 \ldots \ldots \ldots \ldots \ldots 17611$

Received for milk... ............ 3,340 21

Received for four cows.............. 18500

F.XPEDITURES

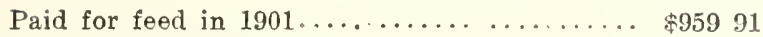

Paid for cows in $1901 \ldots \ldots \ldots \ldots \ldots \ldots \ldots 1,37951$

Freight on milk to Philadelphia market..... 37292

Depreciation...................... 15440

Profit $\ldots \ldots \ldots \ldots \ldots \ldots \ldots \ldots \ldots \ldots \ldots \ldots \ldots \ldots 1,68858$

Average number of cows for the year ................ $27 / 2$

Profit per cow .......................... \$61 58

Cost of keep per cow...................... \$34 $\$ 0$

Amount of milk per cow.................... $8,235 \mathrm{lbs}$.

To the farmer who is anxious to discover the leaks and stop them, this may be worse than no statement, for it is not complete. It places the profit at $\$ 1,688.58$. If the reader has followed 
the author thus far, he knows that this statement does not represent the real profit, for no account whatever is taken of the labor of men and teams, use of wagons, cans, pails, etc., or of use of buildings and their depreciation; neither was there any inventory taken at the beginning or end of the year. Then, too, this is commercial

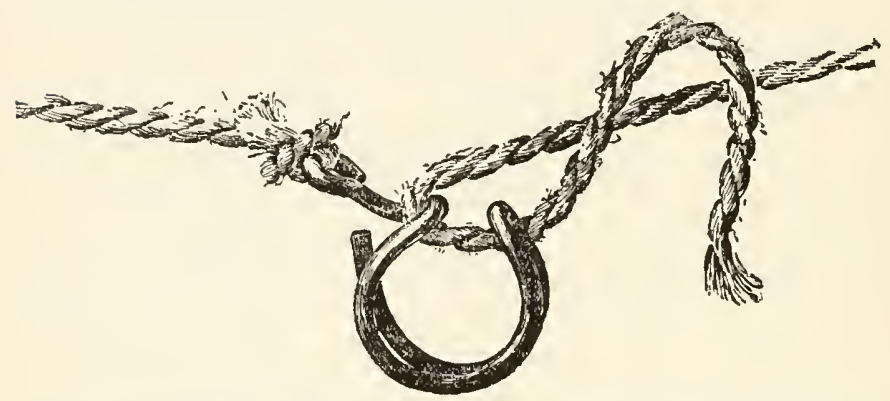

Noose of wire and rope, for holding a small bundle of hay while it is being weighed

dairying. The cows are bought, milked, fattened and sold; hence this statement gives no help to the dairyman who raises most of the cors and the feeds consumed by them.

\section{POULTRY ACCOUNTS}

In a similar way accounts may be kept with poultry when the plant is of such size as to make it necessary to know whether the business is being carried on at a profit or at a loss. Self- 
deception, which so often results in the poultry business, leads to loss and disappointment. If one keeps a score of hens, has his wife feed them from the refuse of kitchen and barn, raises seventy-five chickens, charges nothing for labor or use of building, no accounts are necessary, for the lord of the manor can figure out 100 per cent profit as he finishes the breast of that Plymouth Rock chicken on Christmas day. But it is quite another thing when expensive buildings are erected, hundreds of fowls kept, a man employed throughout the year, incubators and tons of feeds purchased. In such cases full and accurate accounts are indispensable if the true results of the undertaking are to be secured.

The method outlined for determining profit and loss in the dairy and in the fields is equally applicable to poultry. In no other branch of agriculture are there such opportunities for "dead heads" to consume profits as in the poultry business. It may not be practicable to weigh the food of each hen any more than it would be for the boardinghouse keeper to weigh and compute the value of the food consumed by each boarder. But the landlady is wiser than the poultryman, for she looks sharply to the receipts, while the poultryman usually takes no accurate note of either expenditures or receipts, although both can be determined easily and cheaply. 
So far as practicable, the food should be weighed out once a week. It is hardly practicable to weigh the daily rations of the flock. Whenever it is desired to close the account, weigh back whatever food remains and subtract this amount from the total. Then, set a price on the foods used. In case of some of the green foods, which are of comparatively little value, estimates may be made. Knowing the number of eggs or chickens raised in a pen or flock, it will be possible to determine the food cost of eggs and the food cost of chickens.

The time of the care-taker, whether he work full or partial time, should be noted each day on a work report. Having secured the food cost and the labor cost of the entire poultry department, estimate the value of the use of the plant. A careful account of receipts and expenditures and an inventory of stock on hand at the beginning and the end of the year should show, approximately, the profits or losses of the poultry department.

Poultry is kept for one of two purposes-pleasure or profit. If it is maintained for the latter, then strict accounts should be kept. If they are not kept the enthusiast almost invariably deceives himself. He believes he is keeping poultry at a profit, whereas a careful rendering of debit and credit might show a loss, and the loss will hardly compensate for the enthusiasm. 
The hens are usually divided into pens or flocks of twenty to fifty. Different pens may contain different breeds, or fowls of different ages. An account made with each pen is likely to reveal the pens that are being kept at a loss and those that are being kept at a profit. The following memorandum slip will be found convenient for keeping a daily record of egg production. Enough slips can be printed and bound in a single inexpensive book for three to six months. At the close of the day the leaf is filled out and torn off and deposited in a box similar to the one described on page $106 \mathrm{for}$ holding the daily records of milk production.

Observer, Richard RoE

February 2, 1902

Record of EgG Production

Pen No. 1

Pen No. 2

Pen No. 3

Pen No. 4

Pen No. 5

Pen No, 6

Pen No. 7

Pen No. 8

Pen No. 9

Pen No, 10

Pen No. 11

Pen No. 12 .

Pen No. 13.

Pen No. 14

Pen No. 15 .

Total.

H 
The daily records should be condensed and recorded in a book from time to time. From the foregoing records the food cost of egg production is secured. An account should also be kept of chickens sold or used. The eggs and chickens will furnish the credits; the food, the labor and use of plant, the debits. But these will not reveal the profit or loss without considering the inventory at the beginning and end of the year.

Neither can a satisfactory statement of profit or loss be made unless care and judgment are used as to prices in taking inventories at the beginning and the end of the year. Because a few choice birds have been disposed of at liberal prices, the tendency is to place too high a value on the others.

Let it be supposed that the accounts, without the inventories, show a profit of $\$ 20$. This is small, but when the inventories are taken into account, as below, the profits appear to be more satisfactory:

Value of poultry August 1, 1901............\$64200

Value of poultry August 1, 1902............ 78600

Difference ............................ \$144 00 Add profits as above...................... 2000

Total profits ..................... $\$ 16400$

In this case $\$ 144$ of the profits have been used 
to increase the number of fowls. It is seen that no true account can be rendered unless inventories are taken and figured in getting profit and loss.

Weekly Report of Food and Product, Sunday, June 29, 1902 TO JULY 5, 1902

The number of eggs is entered in the columns for each day

\begin{tabular}{|c|c|c|c|c|c|c|c|c|c|}
\hline & & Sun. & Mon. & Tues. & Wed. & Thur. & Fri. & Sat. & Total \\
\hline 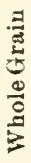 & $\left\{\begin{array}{l}\text { Corn ......... } \\
\text { Wheat........ } \\
\text { Oats......... } \\
\text { Buckwheat . } \\
\ldots \ldots \ldots \ldots \ldots \\
\ldots \ldots \ldots \ldots\end{array}\right.$ & $\begin{array}{l}\cdots \cdots \\
\cdots \cdots \\
\cdots \cdots \\
\cdots \cdots \\
\cdots \cdots \\
\cdots \cdots\end{array}$ & $\begin{array}{l}\cdots \cdots \\
\cdots \cdots \\
\cdots \cdots \\
\cdots \cdots \\
\cdots \cdots \\
\cdots \cdots\end{array}$ & $\begin{array}{l}\cdots \cdots \\
\cdots \cdots \\
\cdots \cdots \\
\cdots \cdots \\
\cdots \cdots \\
\cdots \cdots\end{array}$ & $\begin{array}{l}\cdots \cdots \\
\cdots \cdots \\
\cdots \cdots \\
\cdots \cdots \\
\cdots \cdots \\
\cdots \cdots \\
\cdots\end{array}$ & $\begin{array}{l}\cdots \cdots \\
\cdots \cdots \\
\cdots \cdots \\
\cdots \cdots \\
\cdots \cdots \\
\cdots \cdots\end{array}$ & $\begin{array}{l}\cdots \cdots \\
\cdots \cdots \\
\cdots \cdots \\
\cdots \cdots \\
\cdots \cdots \\
\cdots \cdots\end{array}$ & $\begin{array}{l}\cdots \cdots \\
\cdots \cdots \\
\cdots \cdots \\
\cdots \cdots \\
\cdots \cdots \\
\cdots \cdots\end{array}$ & $\begin{array}{l}\ldots \ldots \ldots \\
\ldots \ldots \ldots \\
\cdots \ldots \ldots \\
\cdots \ldots \ldots \\
\cdots \ldots \ldots \\
\ldots \ldots \ldots\end{array}$ \\
\hline ت્ّ & $\left\{\begin{array}{l}\text { Corn meal... } \\
\text { Wheat bran.. } \\
\text { Wheat mid... } \\
\ldots \ldots \ldots \ldots \ldots \\
\ldots \ldots \ldots \ldots \ldots \\
\ldots \ldots \ldots \ldots \ldots \\
\ldots \ldots \ldots \ldots\end{array}\right.$ & $\begin{array}{l}\cdots \cdots \\
\cdots \cdots \\
\cdots \cdots \\
\cdots \cdots \\
\cdots \cdots \\
\cdots \cdots \\
\cdots \cdots\end{array}$ & $\begin{array}{l}\ldots \ldots \\
\cdots \cdots \\
\cdots \cdots \\
\cdots \cdots \\
\cdots \cdots \\
\cdots \cdots \\
\cdots \cdots\end{array}$ & $\begin{array}{l}\cdots \cdots \\
\cdots \cdots \\
\cdots \cdots \\
\cdots \cdots \\
\cdots \cdots \\
\cdots \cdots \\
\cdots \cdots \\
\cdots\end{array}$ & $\begin{array}{l}\cdots \cdots \\
\cdots \cdots \\
\cdots \cdots \\
\cdots \cdots \\
\cdots \cdots \\
\cdots \cdots\end{array}$ & $\begin{array}{l}\cdots \cdots \\
\cdots \cdots \\
\cdots \cdots \\
\cdots \cdots \\
\cdots \cdots \\
\cdots \cdots \\
\cdots \cdots\end{array}$ & $\begin{array}{l}\ldots \cdots \\
\cdots \cdots \\
\cdots \cdots \\
\cdots \cdots \\
\cdots \cdots \\
\cdots \cdots \\
\cdots \cdots\end{array}$ & $\begin{array}{l}\cdots \cdots \\
\cdots \cdots \\
\cdots \cdots \\
\cdots \cdots \\
\cdots \cdots \\
\cdots \cdots \\
\cdots \cdots\end{array}$ & 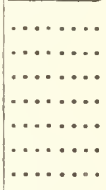 \\
\hline 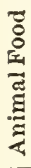 & $\begin{array}{l}\text { Meat scrap ... } \\
\text { Fresh ground } \\
\text { bone........ } \\
\text { Skim'd milk } \\
\text { Shells or grit } \\
\text {............. }\end{array}$ & $\begin{array}{c}\cdots \\
\cdots \\
\cdots \\
\cdots \cdots\end{array}$ & $\ldots \ldots$ & $\cdots \cdots$ & $\begin{array}{c}\cdots \cdots \\
\cdots \ldots \ldots \\
\cdots \cdots \\
\cdots \cdots\end{array}$ & $\begin{array}{c}\cdots \cdots \\
\cdots \cdots \\
\cdots \cdots \\
\cdots \cdots \\
\cdots\end{array}$ & $\begin{array}{l}\cdots \cdots \\
\cdots \cdots \\
\cdots \cdots \\
\cdots \cdots \\
\cdots \cdots\end{array}$ & $\begin{array}{c}\cdots \cdots \\
\cdots \cdots \\
\cdots \cdots \\
\cdots \cdots \\
\cdots\end{array}$ & $\begin{array}{l}\cdots \cdots \\
\ldots \ldots \\
\cdots \cdots \\
\cdots \cdots \\
\cdots \cdots\end{array}$ \\
\hline 5 & $\begin{array}{l}\text { Cabbage..... } \\
\text { Beets........ } \\
\text { Turnips..... } \\
\text { Potatoes..... } \\
\text { Clover hay... } \\
\ldots . . . . . . . . . .\end{array}$ & $\mid \begin{array}{l}\cdots \cdots \\
\cdots \cdots \\
\cdots \cdots \\
\cdots \cdots \\
\cdots \cdots\end{array}$ & $\begin{array}{c}\ldots \ldots \\
\cdots \ldots \ldots \\
\cdots \ldots \ldots \\
\cdots \ldots\end{array}$ & $\begin{array}{c}\cdots \cdots \\
\cdots \cdots \\
\cdots \cdots \\
\cdots \cdots\end{array}$ & $\begin{array}{l}\cdots \cdots \\
\cdots \cdots \\
\cdots \cdots \\
\cdots \cdots \\
\cdots \cdots \\
\cdots \cdots \\
\cdots \cdots\end{array}$ & $\begin{array}{c}\cdots \cdots \\
\cdots \cdots \\
\cdots \cdots \\
\cdots \cdots\end{array}$ & $\begin{array}{l}\cdots \cdots \\
\cdots \cdots \\
\cdots \cdots \\
\cdots \cdots \\
\cdots \cdots \\
\cdots \cdots\end{array}$ & $\begin{array}{l}\cdots \cdots \\
\cdots \cdots \\
\cdots \cdots \\
\cdots \cdots \\
\cdots \cdots \\
\cdots \cdots \\
\cdots \cdots\end{array}$ & $\begin{array}{l}\cdots \cdots \cdots \\
\cdots \ldots \ldots \\
\cdots \ldots \ldots \\
\cdots \cdots \\
\cdots \cdots \cdots \\
\cdots \cdots\end{array}$ \\
\hline
\end{tabular}

No. (if any) hens sick during week

No. (if any) hens died or killed during week.

The above record is true and correct to the best of my knowledge and belief. 
ACCOUNTS WITH RATIONS OF FARM ANIMALS

There are other things besides those found in the ledger which should be taken account of in dealing with animals. It is not enough to note the value of labor and food expended in the stables, for if no attention is paid to the character of the foods there may be loss which could be changed into profit by a more judicious compounding of the animal's ration.

For instance, the milch cow does better when fed a ration which does not depart widely from 1:5.4, while horses, at slow, laborious work, should have the nutritive ratio widened to at least $1: 7,-$ that is, one unit of digestible proteids to seven units of carbohydrates, including the vegetable fats multiplied by $2 \frac{1}{4}$. It is evident that milch cows, especially in the corn and timothy hay districts, are likely to be fed too wide a ration, that is, one which contains relatively too much carbohydrates and too little protein. In districts where alfalfa and oats are the chief food crops, the work-horses are likely to be fed a too narrow ration - one containing relatively too much protein and too little carbohydrates. In order to give opportunity for the reader to take account of feeding stuffs, and to discover how to feed domestic animals scientifically and economically, the following explanations and tables, prepared 
by John L. Stone, ${ }^{*}$ investigator and instructor in the College of Agriculture of Cornell University, are appended:

Principles of Feeding.-The various substances found in animal bodies may, for convenience, be grouped under four heads: (1) water; (2) ash, or mineral matter; (3) fat; (4) nitrogenous matter or protein. These substances occur in the animal body in somewhat varying proportions, depending upon age, condition, treatment, and other factors.

Water is an essential constituent of the animal body, and constitutes from 40 to 60 per cent of its live weight. Ash occurs mainly in the bones and constitutes from 2 to 5 per cent of the live weight. The fat occurs in greatly varying proportions, but rarely is less than 6 or more than 30 per cent. All those substances containing nitrogen are classed as protein. They constitute an important group, of which washed lean meat and the white of egg may be taken as types. Proteids contain about 16 per cent of the element nitrogen, and are the only class into the composition of which this element enters. All the working machinery of the body, such as flesh, skin, bones, hair, internal organs, brain and nerves, contain a large proportion of protein.

Composition of Food Materials. - The same four

* Bull. 154, Cornell Exp. Sta. 
groups of substances found in animal bodies, viz., water, ash, fat and protein, are also found in the food that animals consume. In addition, the food of herbivorous animals contains a class of substances called carbohydrates.

a. Water.-All food stuffs, no matter how dry they may seem, contain a considerable amount of water. In grains and dried fodders, it ranges from 8 to 15 per cent of the material, in green forage and silage it is about 80 per cent, while in some roots it amounts to 90 per cent. While water is essential to animal life and the water in the food fulfils the same function as that drunk by the animal, we do not value food materials for the water they contain, and computations are based upon the water-free or dry matter.

b. Ash.-When a food stuff is burned till the organic matter is all driven off, the residue is the ash. It is composed largely of lime, magnesia, potash, soda, iron, chlorine, and carbonic, sulfuric and phosphoric acids. The ash of the food is the source of mineral matter of the animal body, and as such is of great importance. Ordinary combinations of feeding stuffs, however, contain an abundant supply of mineral matter for the use of the animal; so that it is not a matter of practical concern except as it has a bearing on the mineral elements of fertility in the manure.

c. Fats.-This group embraces the materials 
which may be dissolved from a feeding stuff by ether. It includes, besides the true fats, wax and coloring matter. Fat in the food may be either stored in the body as fat, or burned to produce heat and energy.

d. Carbohydrates. - This term includes two groups: (1) nitrogen-free extract, such as starch, sugar, gum, etc., and (2) fiber, or the woody part of plants. The former are rather freely digested, the latter much less so, though fulfilling the same function to the extent to which they are digested. The carbohydrates constitute the largest part of vegetable foods. They are not stored in the animal body as such, but are converted into fat or used (burned) to produce heat and energy.

Since the carbohydrates and fat serve nearly the same purpose in the animal economy, they may, for convenience, be grouped together. Experiments, however, have shown that fat is about $2 \frac{1}{4}$ times as effective as a food as are the carbohydrates. Hence it is customary to multiply the amount of fat by $2 \frac{1}{4}$ to reduce it to a "starch equivalent" before adding it to the amount of the carbohydrates.

$e$. Protein.-The protein of foods, like that of the animal body, is characterized by containing nitrogen. It, therefore, is frequently termed "nitrogenous matter." The term "albumenoids" is sometimes used to designate this group, though 
it more correctly implies a certain class of protein substances. The function of protein in the food is, first of all, to build up and repair the working machinery of the body, and to supply protein for the production of milk, wool, etc. No other food constituent can fulfil this function.

The importance of a sufficient supply of protein in the ration is, therefore, apparent. If in excess of the amount required to build up and repair the waste of the body the protein may be converted into fat and deposited as such or used to produce heat and energy. Its efficiency for these purposes is about the same as the carbohydrates, but as it is usually far more expensive to supply than the carbohydrates, economy would dictate that only so much protein should be supplied to the animal as will suffice to repair the wastes of the animal machinery and build up new growth in case of growing animals, or for the production of milk, wool, etc.

Compounding of Rations.-a. Nutritive ratio.Since the protein on the one hand and the carbohydrates and fat on the other, serve, in the main, different purposes in the animal economy, it becomes evident that the relative amounts of these nutrients in the food are important. This relation is expressed as the "nutritive ratio," which means the relation of digestible protein to digestible carbohydrates and fat-the fat having been 
multiplied by $2 \frac{1}{4}$ before adding to the carbohydrates, as explained above. The nutritive ratio is found by dividing the carbohydrates, plus $2 \frac{1}{4}$ times the fat, by the protein. In the accompanying table, No. II, the sum of the carbohydrates and fat, thus obtained, is given in the third column, which, divided by the protein as given in the second column, gives the second term of the nutritive ratio in the fifth column.

A feeding stuff having a large proportion of carbohydrates and fat as compared to protein, is said to have a "wide" nutritive ratio, whereas one having a small proportion of carbohydrates and fat as compared to protein has a "narrow" ratio. While these terms are relative, it may be said that a ratio greater than $1: 6$ is wide, while one less than 1:5 is narrow. The composition of feeding stuffs, that is, the proportion in which the different nutrients occur, is determined by chemical analysis, but the amount of each nutrient that is actually digestible has been determined by careful experiments with living animals. Only the digestible nutrients are considered in the tables given in this publication.

$b$. Feeding Standards.-The amount of nutrients required and the proportions in which each should be given, vary with the kind of animal and the purpose for which it is kept,- whether it is growing, being fattened, doing work, or pro- 
ducing milk or wool. Thus an ox at rest requires less food than an ox at work and the various nutrients in different proportions; a cow in milk requires more food than one not in milk and to have the nutrients differently balanced.

Various investigators have condensed the results of many experiments and much practical experience into what are called "feeding standards," which attempt to state what is in general, and under average conditions, a good ration for the purpose in view. While these standards cannot be considered as mathematically exact, still large practical experience has demonstrated their great value as suggestions to feeders.

In Table I, under the title of Feeding Standards, are given the approximate requirements of various classes of animals and under varying conditions. These standards are mostly from German sources, but they have been found to be very helpful to American feeders. They are presented here as arranged by Armsby, in Circular of Information No. 1, "Computation of Rations for Farm Animals," Pennsylvania State College. The standards are for animals of 1,000 pounds live weight, and may be increased or diminished for larger or sinaller animals, though it is probable that the individuality of the animal, its power to assimilate and produce, will have more to do with the varying of the ration than its weight. It is permissi- 
ble, perhaps, to depart from the amounts given in the first column under the head of "Dry Matter," more than in any other way. The digestive apparatus of farm animals is elastic and accom-

TABLE I-Feeding Standards

A-Per day and at 1,000 pounds live weight.*

\begin{tabular}{|c|c|c|c|c|c|c|}
\hline & \multirow[b]{2}{*}{$\begin{array}{c}\text { Dry } \\
\text { matter. }\end{array}$} & \multicolumn{3}{|c|}{ Digestible. } & \multirow[b]{2}{*}{$\begin{array}{c}\text { Nutri. } \\
\text { tive } \\
\text { ratio. }\end{array}$} \\
\hline & & & Protein. & $\begin{array}{c}\text { Carbo- } \\
\text { hydrates } \\
\text { and fats. } \\
\end{array}$ & Total. & \\
\hline \multicolumn{2}{|c|}{ 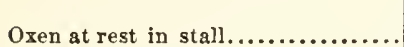 } & $\begin{array}{l}L b s . \\
17.5\end{array}$ & $\begin{array}{l}L b s . \\
0.7\end{array}$ & $\begin{array}{l}L b s . \\
8.3\end{array}$ & $\begin{array}{l}\text { Lbs. } \\
9.0\end{array}$ & $1: 11.9$ \\
\hline \multirow{2}{*}{\multicolumn{2}{|c|}{$\begin{array}{l}\text { Wool sheep, coarser breeds............... } \\
\text { Wool sheep, finer breeds. }\end{array}$}} & 20.0 & 1.2 & 10.8 & 12.0 & $1: 9.0$ \\
\hline & & 22.5 & & 12.0 & 13.5 & $1: 8.0$ \\
\hline & 24.0 & 1.6 & 12.0 & 13.0 & $1: 7.5$ \\
\hline \multicolumn{2}{|c|}{$\begin{array}{l}\text { Oxen moderately worked } \ldots \ldots \ldots \ldots \ldots \\
\text { Oxen heavily worked } \ldots \ldots \ldots \ldots \ldots \ldots\end{array}$} & 26.0 & 2.4 & 14.3 & 16.7 & $1: 6.0$ \\
\hline \multirow{2}{*}{\multicolumn{2}{|c|}{ 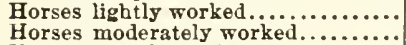 }} & 20.0 & 1.5 & 10.4 & 11.9 & $1: 6.9$ \\
\hline & & 21.0 & 1.7 & 11.8 & 13.5 & $1: 6.9$ \\
\hline \multicolumn{2}{|c|}{ Horses heavily worked............... } & 23.0 & 2.3 & 14.3 & 16.6 & $1: 6.2$ \\
\hline \multicolumn{2}{|c|}{ Milk cows, Wolff's standard......... } & 24.0 & 2.5 & 13.4 & 15.9 & $1: 5.4$ \\
\hline \multicolumn{2}{|c|}{ Milk cows, Wisconsin standard....... } & 24.5 & 2.2 & 14.9 & 17.1 & $1: 6.8$ \\
\hline \multirow{2}{*}{\multicolumn{2}{|c|}{$\begin{array}{l}\text { Fattening oxen, preliminsry period.. } \\
\text { Fattening oxen, main period,........ }\end{array}$}} & 27.0 & 2.5 & 16.1 & 18.6 & $1: 6.4$ \\
\hline & & 26.0 & 3.0 & 16.4 & 19.4 & $1: 5.5$ \\
\hline \multicolumn{2}{|c|}{$\begin{array}{l}\text { Fattening oxen, main period............. } \\
\text { Fattening oxen, finishing period.... }\end{array}$} & 25.0 & 2.7 & 16.2 & 18.9 & $1: 6.0$ \\
\hline \multicolumn{2}{|c|}{ Fattening sheep, preliminary period. } & 26.0 & 3.0 & 16.3 & 19.3 & $1: 5.4$ \\
\hline \multicolumn{2}{|c|}{ Fattening sheep, main period......... } & 25.0 & 3.5 & 15.8 & 19.3 & $1: 4.5$ \\
\hline & 36.0 & 5.0 & 27.5 & 32.5 & $1: 5.5$ \\
\hline & & 31.0 & 4.0 & 24.0 & 28.0 & $1: 6.0$ \\
\hline \multicolumn{2}{|c|}{$\begin{array}{l}\text { Fattening swine, main period......... } \\
\text { Fattening swine, finishing period.... }\end{array}$} & 23.5 & 2.7 & 17.5 & 20.2 & $1: 6.5$ \\
\hline \multicolumn{7}{|c|}{ Growing cattle: } \\
\hline \multicolumn{7}{|c|}{$\begin{array}{l}\text { Average live weight } \\
\text { Age. Months. per head. }\end{array}$} \\
\hline \multicolumn{2}{|c|}{ 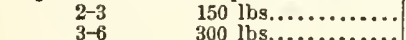 } & 22.0 & 4.0 & 18.3 & 22.3 & $1: 4.6$ \\
\hline \multirow{2}{*}{\multicolumn{2}{|c|}{ 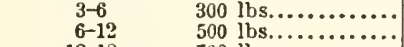 }} & 23.4 & 3 & 15.8 & 19.0 & $1: 4.9$ \\
\hline & & 24.0 & 2.5 & 14.9 & 17.4 & $1: 6.0$ \\
\hline \multirow{2}{*}{\multicolumn{2}{|c|}{$\begin{array}{ll}12-18 & 700 \mathrm{lbs} . \ldots \ldots \ldots \ldots \\
18-24 & 850 \mathrm{lbs} . \ldots \ldots \ldots \ldots\end{array}$}} & 24.0 & 2.0 & 13.9 & 15.9 & $1: 7.0$ \\
\hline & & 24.0 & 1.6 & 12.7 & 14.3 & $1: 8.0$ \\
\hline \\
\hline \multicolumn{2}{|c|}{$\begin{array}{l}\text { Growing sheep: } \\
5-6\end{array}$} & 28.0 & 3.2 & 17.4 & 20.6 & $1: 5.4$ \\
\hline \multirow{2}{*}{\multicolumn{2}{|c|}{$\begin{array}{l}6-8 \\
8-11\end{array}$}} & 25.0 & $\begin{array}{l}2.7 \\
2.1\end{array}$ & $\begin{array}{l}14.7 \\
12.5\end{array}$ & $\begin{array}{l}17.4 \\
14.6\end{array}$ & $\begin{array}{l}k \times 5.4 \\
1: 6.0\end{array}$ \\
\hline & & $\begin{array}{l}23.0 \\
22.5\end{array}$ & $\begin{array}{l}2.1 \\
1.7\end{array}$ & $\begin{array}{l}12.5 \\
11.8\end{array}$ & $\begin{array}{l}14.0 \\
13.5\end{array}$ & $\begin{array}{l}1: 6.0 \\
1: 7.0\end{array}$ \\
\hline $\begin{array}{r}11-15 \\
15-20\end{array}$ & 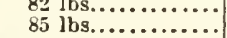 & 22.0 & 1.4 & 11.1 & 12.5 & $1: 8.0$ \\
\hline Growing fat & & & & & & \\
\hline $2-3$ & 50 lbs... & 42.0 & 7.5 & 30.0 & 37.5 & $1: 4.0$ \\
\hline & 100 lbs.. & 34.0 & 5.0 & 25.0 & 30.0 & $1: 5.0$ \\
\hline $5-6$ & 125 lbs..... & 31.5 & 4.3 & 23.7 & 28.0 & $1: 5.5$ \\
\hline & 170 lbs........ & 27.0 & 3.4 & 20.4 & 23.8 & $1: 6.0$ \\
\hline 9-12 & 250 lbs...... & 21.0 & 2.5 & 16.2 & 18.7 & $1: 6.5$ \\
\hline
\end{tabular}

* The fattening rations are calculated for $1,000 \mathrm{lbs}$. live weight at the beginning of the fattening. 
Table I - Feeding Standards - Continued B-Per day and per head.

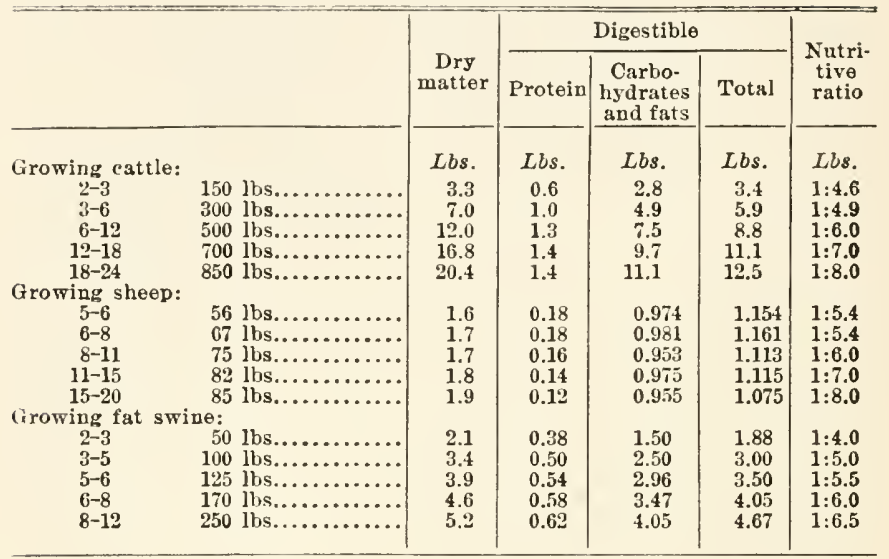

modates itself very readily to the varying bulk of food. In the last column is given the nutritive ratio, which should, perhaps, be adhered to with some care, trusting to the appetite of the animal (which will be controlled largely by its power of digesting and producing) to indicate the amount of nutrients required. As a rule, the most rapid fattening, or growth, and abundant production are most economical, and these results are best secured by feeding an abundant and well-balanced ration (well up to the limit of the animal's appetite) while the dry matter is not permitted to lise much above the standard. 
Table II gives a list of the feeding stuffs in most common use in New York state. Column one is headed "dry matter"; column two, "digestible protein"; column three, "digestible carbohydrates $+($ fat $\times 21 / 4)$ "; column four, "total" (which is the sum of two and three); colnmn five, "nutritive ratio." In each of these columns are given the computations of the various food stuffs from one pound up to the amount that is likely to be used in compounding any ration. In the case of the coarse fodders, to save space, the increase is made by more than one pound at a time, but intermediate amounts can readily be obtained from the table if desired. In no case are the calculations for ten pounds of a feeding stuff given, as these can be obtained at once from the figures for one pound, by simply moving the decimal point one place to the right.

These computations are based upon the table of "Average Digestible Nutrients in American Feeding Stuffs" given in Professor W. A. Henry's recent book, "Feeds and Feeding." The aim has been to carry the computations involved in formulating rations as near completion as possible, and to present the figures in such simple form that no feeder will have difficulty in comparing the ration he is feeding with the standards, and correcting it, if necessary, to conform thereto. 
TABLE I

Digrstible Nutrients in 'THE STATEd Amounts OF THE MORE Common Feeding Stuffs

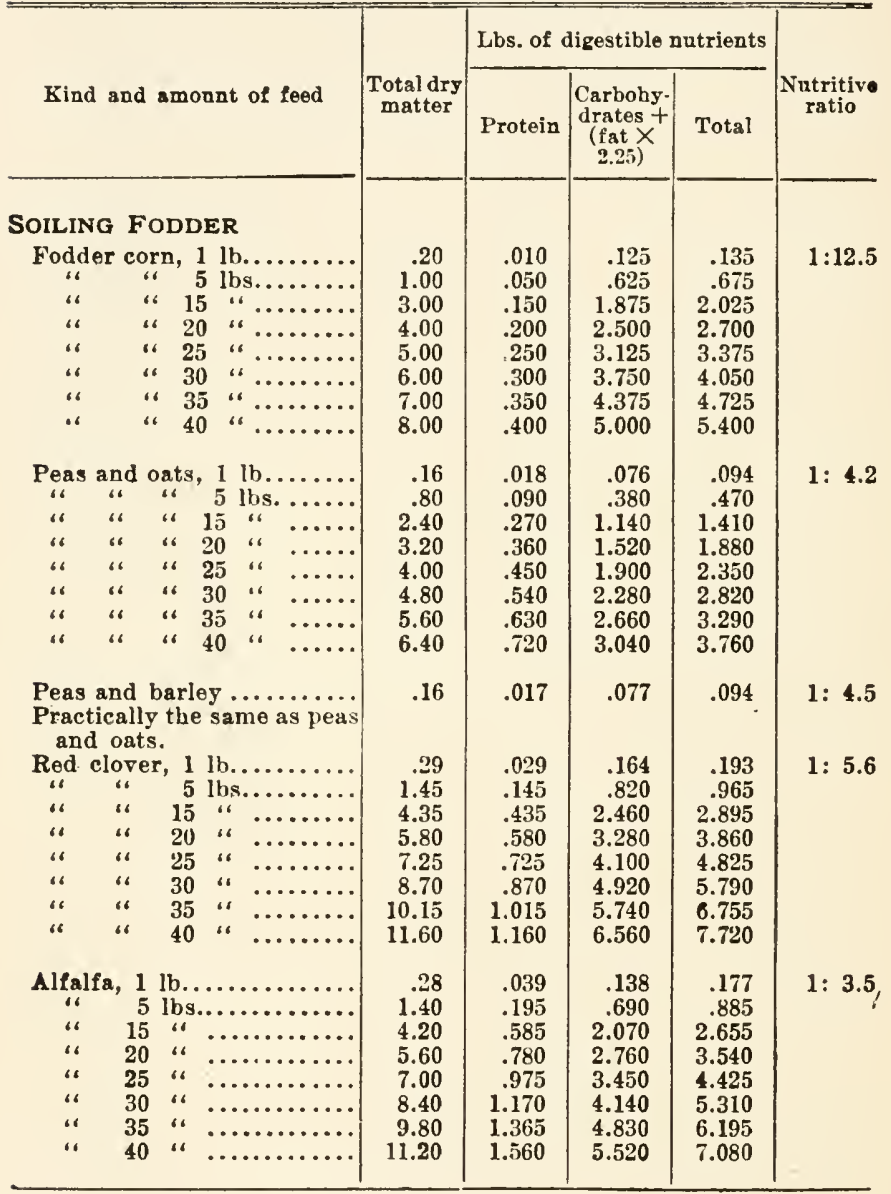


TABLE II - Continued

\begin{tabular}{|c|c|c|c|c|c|c|}
\hline \multirow{2}{*}{\multicolumn{2}{|c|}{ Kind and amount of feed }} & \multirow[b]{2}{*}{$\begin{array}{c}\text { Total dry } \\
\text { matter }\end{array}$} & \multicolumn{3}{|c|}{ Lbs, of digestible natrients } & \multirow[b]{2}{*}{$\begin{array}{l}\text { Nutritive } \\
\text { ratio }\end{array}$} \\
\hline & & & Protein & $\begin{array}{c}\text { Carbohy- } \\
\text { drates }+ \\
\text { (fat } X \\
2.25)\end{array}$ & Total & \\
\hline \multirow{2}{*}{\multicolumn{7}{|c|}{ SOILING FODDER - Continued }} \\
\hline & & .29 & .020 & .169 & .189 & $1: 8.4$ \\
\hline & " 5 lbs.... & 1.45 & .100 & .845 & .945 & \\
\hline ' & “ 15 “.... & 4.35 & .300 & 2.535 & 2.835 & \\
\hline & " $\quad 20$ " $\ldots \ldots$ & 5.80 & .400 & 3.380 & 3.780 & \\
\hline ‘ & " 25 " & 7.25 & .500 & 4.225 & 4.725 & \\
\hline ، & “ 30 " & 8.70 & .600 & 5.070 & 5.670 & \\
\hline ‘ & " 35 " $\ldots \ldots$ & 10.15 & .700 & 5.915 & 6.615 & \\
\hline & " 40 ".... & 11.60 & .800 & 6.760 & 7.560 & \\
\hline Corn & silage, 1 lb......... & .21 & .009 & .129 & .138 & $1: 14.3$ \\
\hline$\because$ & " 5 lbs......... & 1.05 & .045 & .645 & .690 & \\
\hline “ & " $\quad 15 \quad " \ldots \ldots \ldots$ & 3.15 & .135 & 1.935 & 2.070 & \\
\hline "6 & “ $\quad 20$ “ $\quad 20 \ldots \ldots$ & 4.20 & .180 & 2.580 & 2.760 & \\
\hline “" & “ $\quad 25$ “ $\quad 3 \ldots \ldots \ldots$ & 5.25 & .225 & 3.225 & 3.450 & \\
\hline$\because$ & « $\quad 30$ « $\quad 35 \ldots \ldots \ldots$ & $\begin{array}{l}6.30 \\
7.35\end{array}$ & .270 & 3.870 & 4.140 & \\
\hline “، & " 40 " $4 . \ldots \ldots$ & 8.40 & .360 & 5.160 & 5.520 & \\
\hline “ & " 45 " & 9.45 & .405 & 5.805 & 6.210 & \\
\hline "6 & " 50 " $\quad \ldots \ldots \ldots$ & 10.50 & .450 & 6.450 & 6.900 & \\
\hline \multicolumn{7}{|c|}{ ROOTS AND TUBERS } \\
\hline Potat & oes, 1 lb............ & .21 & .009 & .165 & .174 & $1: 18.3$ \\
\hline$\because$ & 5 lbs.................... & 1.05 & .045 & .825 & .870 & \\
\hline “" & $15 \quad$ \# $\quad \ldots \ldots \ldots$ & 3.15 & .135 & 2.475 & 2.610 & \\
\hline “6 & $20 "$ " $\quad \ldots \ldots \ldots \ldots$ & 4.20 & .180 & 3.300 & 3.480 & \\
\hline & $256 \quad \ldots \ldots \ldots \ldots$ & 5.25 & .225 & 4.125 & 4.350 & \\
\hline Beet, & mangel, 1 lb......... & .09 & .011 & .056 & .067 & $1: 5.1$ \\
\hline ، & $5 \mathrm{lbs} . . . \ldots \ldots$ & .45 & .055 & .280 & .335 & \\
\hline " & " $\quad 15$ " $\ldots \ldots \ldots$ & 1.35 & .165 & .840 & 1.005 & \\
\hline " & $20 \quad * \ldots \ldots$. & 1.80 & .220 & 1.120 & 1.340 & \\
\hline "4 & “ $\quad 25$ “....... & 2.25 & .275 & 1.400 & 1.675 & \\
\hline "6 & “ $\quad 30$ " $\ldots \ldots \ldots$ & 2.70 & .330 & 1.680 & 2.010 & \\
\hline Beet, & sugar, 1 lb......... & .13 & .011 & .104 & .115 & $1: 9.4$ \\
\hline " & “ 5 Jbs......... & .65 & .055 & .520 & .575 & \\
\hline “ & " 15 " $\quad \ldots \ldots \ldots$ & 1.95 & .165 & 1.560 & 1.725 & \\
\hline “" & $20 " \ldots \ldots \ldots$ & 2.60 & .220 & 2.080 & 2.300 & \\
\hline “ & “ 20 ، $\quad 30 \cdots \cdots$ & 3.25 & .270 & 2.000 & 2.800 & \\
\hline & 00 & & & & & \\
\hline
\end{tabular}


TABLE II - Continued

\begin{tabular}{|c|c|c|c|c|c|}
\hline \multirow[b]{2}{*}{ Kind and amount of feed } & \multirow[b]{2}{*}{$\begin{array}{c}\text { Total dry } \\
\text { matter }\end{array}$} & \multicolumn{3}{|c|}{ Lbs. of digestible nutrients } & \multirow[b]{2}{*}{$\begin{array}{l}\text { Sutritive } \\
\text { ratio }\end{array}$} \\
\hline & & Protein & $\begin{array}{c}\text { Carbohy- } \\
\text { lrates }+ \\
(\text { fat } X \\
2.25)\end{array}$ & Total & \\
\hline \multirow{2}{*}{\multicolumn{6}{|c|}{$\begin{array}{l}\text { ROOTS and TUBERS-Cont'd. } \\
\text { Carrot, } 1 \text { lb. . . . . . . . }\end{array}$}} \\
\hline & .11 & .008 & .082 & .090 & $1: 10.3$ \\
\hline " 5 lbs. . . . . . . . . & .55 & .040 & .410 & .450 & \\
\hline 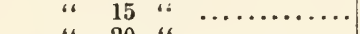 & 1.65 & .120 & 1.230 & 1.350 & \\
\hline$\because \quad 20$ " $\quad$ " $\quad \ldots \ldots \ldots \ldots$ & 2.20 & .160 & 1.640 & 1.800 & \\
\hline$" \quad 25$ " $\quad \ldots \ldots \ldots \ldots \ldots$ & 2.75 & .200 & 2.050 & 2.250 & \\
\hline " $\quad 30 \quad " \quad \ldots \ldots \ldots \ldots \ldots$ & 3.30 & .240 & 2.460 & 2.700 & \\
\hline Flat turnip, 1 lb............ & .10 & .01 & .077 & .087 & \\
\hline “ $\quad$ “ 5 lbs.......... & .50 & .05 & .385 & .435 & \\
\hline " 15 " $\quad \ldots \ldots \ldots \ldots$ & 1.50 & .15 & 1.155 & 1.350 & \\
\hline " $\quad 20 "$ " $\ldots \ldots \ldots$ & 2.00 & .20 & 1.540 & 1.740 & \\
\hline “ $\quad 25 " \ldots \ldots \ldots$ & 2.50 & .25 & 1.925 & 2.175 & \\
\hline " $\quad 30$ " $\quad \ldots \ldots \ldots$ & 3.00 & .30 & 2.310 & 2.610 & $1: 7.7$ \\
\hline \multicolumn{6}{|l|}{ HAY AND STRAW } \\
\hline 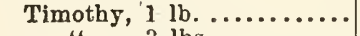 & .87 & .028 & .465 & .493 & $1: 16.6$ \\
\hline$" \quad 3$ lbs.............. & 2.61 & .084 & 1.395 & 1.479 & \\
\hline $5 \quad \because \quad \cdots \cdots \cdots \cdots \cdots$ & 4.35 & .140 & 2.325 & 2.465 & \\
\hline $\begin{array}{llll}7 & 16 \\
8 & 6 & \cdots & \ldots\end{array}$ & 6.09 & .196 & 3.255 & 3.451 & \\
\hline $\begin{array}{llll}9 & \text { ، } & \ldots \ldots \ldots \ldots\end{array}$ & $\begin{array}{l}6.96 \\
7.83\end{array}$ & .224 & $\begin{array}{l}3.720 \\
4.185\end{array}$ & $\begin{array}{l}3.944 \\
4.437\end{array}$ & \\
\hline $12 \quad 6 \quad \ldots \ldots \ldots \ldots$ & 10.44 & .336 & 5.580 & 5.916 & \\
\hline 15 " $\quad \ldots \ldots \ldots \ldots$ & 13.05 & .420 & 6.975 & 7.395 & \\
\hline 18 “ $\quad \ldots \ldots \ldots \ldots$ & 15.66 & .504 & 8.370 & 8.874 & \\
\hline " $\quad 20$ " $\quad \ldots \ldots \ldots \ldots$ & 17.40 & .560 & 9.300 & 9.860 & \\
\hline \multicolumn{6}{|l|}{ Mired grasses and clover, } \\
\hline 1 lb..................... & .87 & .062 & .460 & .522 & 1: 7.4 \\
\hline 3 lbs......... & 2.61 & .186 & 1.381 & 1.566 & \\
\hline $5 \quad " \quad \ldots \ldots \ldots \ldots \ldots \ldots \ldots \ldots$ & 4.35 & .310 & 2.300 & 2.610 & \\
\hline 7 " 7 , $\ldots \ldots \ldots \ldots \ldots \ldots$ & 6.09 & .434 & 3.220 & 3.654 & \\
\hline 8 " $8 \ldots \ldots \ldots \ldots \ldots \ldots$ & 6.96 & .496 & 3.680 & 4.176 & \\
\hline $964 \ldots \ldots \ldots$ & 7.83 & .558 & 4.140 & 4.698 & \\
\hline $12 " 1, \ldots \ldots \ldots \ldots \ldots \ldots$ & 10.44 & .744 & 5.520 & 6.264 & \\
\hline 15 " $\quad \ldots \ldots \ldots \ldots \ldots \ldots \ldots$ & 13.05 & .930 & 6.900 & 7.830 & \\
\hline 18 " $18 \ldots \ldots \ldots \ldots \ldots \ldots \ldots$ & 15.66 & 1.116 & 8.280 & 9.396 & \\
\hline $20 \quad * \ldots \ldots \ldots \ldots \ldots \ldots \ldots$ & 17.40 & 1.240 & 9.200 & 10.440 & \\
\hline Hungarian hay, 1 lb... & .92 & .045 & .546 & .591 & $1: 12.1$ \\
\hline $3 \mathrm{lbs} . .$. & 2.76 & .135 & 1.638 & 1.773 & \\
\hline $\begin{array}{lllll} & 4 & 4 & \ldots\end{array}$ & 4.60 & .225 & 2.730 & 2.955 & \\
\hline
\end{tabular}


TAble II--Continued

\begin{tabular}{|c|c|c|c|c|c|}
\hline \multirow[b]{2}{*}{ Kind and amount of feed } & \multirow[b]{2}{*}{$\begin{array}{c}\text { Total dry } \\
\text { matter }\end{array}$} & \multicolumn{3}{|c|}{ Lbs. of digestible nutrients } & \multirow[b]{2}{*}{$\begin{array}{l}\text { Nutritive } \\
\text { ratio }\end{array}$} \\
\hline & & Protein & $\mid \begin{array}{c}\text { Carbohy- } \\
\text { drates }+ \\
\text { (fat } X \\
2.25)\end{array}$ & Total & \\
\hline \multicolumn{6}{|l|}{ HAY and STRAW-Continueủ. } \\
\hline Hungarian hay, 7 lbs..... & 6.44 & .315 & 3.822 & 4.137 & \multirow{14}{*}{$1: 5.8$} \\
\hline$\because \quad \because 8 \quad \ldots \ldots$ & 7.36 & .360 & 4.368 & 4.728 & \\
\hline $\begin{array}{lllll} & & 9 & \cdots & \ldots\end{array}$ & 8.28 & .405 & 4.914 & 5.319 & \\
\hline$" 12 " 6 \ldots$. & 11.04 & .540 & 6.552 & 7.092 & \\
\hline Red elover hay, $1 \mathrm{lb} . .$. . & .85 & .068 & .396 & .464 & \\
\hline " " " 3 lbs..... & 2.55 & .204 & 1.188 & 1.392 & \\
\hline “ 5 lbs...... & 4.25 & .340 & 1.980 & 2.320 & \\
\hline$\because 7 \because \ldots \ldots$ & 5.95 & .476 & 2.772 & 3.248 & \\
\hline “ $\quad 8$ " $\quad \ldots \ldots$ & 6.80 & .544 & 3.168 & 3.712 & \\
\hline $\begin{array}{lllll} & 6 & 9 & 1 & \ldots\end{array}$ & 7.65 & .612 & 3.564 & 4.176 & \\
\hline$\because \quad 12 \quad \cdots \quad \ldots \ldots$ & 10.20 & .816 & 4.752 & 5.568 & \\
\hline . 15 " $\quad \ldots \ldots$ & 12.75 & 1.020 & 5.940 & 6.960 & \\
\hline$\because 18$ “ $\ldots$. & 15.30 & 1.224 & 7.128 & 8.352 & \\
\hline . 20 " $\ldots$. & 17.00 & 1.360 & 7.920 & 9.280 & \\
\hline Alfulfa hay, 1 lb. ......... & .92 & .110 & .423 & .533 & \multirow[t]{10}{*}{$1: 3.8$} \\
\hline " 3 lbs............ & 2.76 & .330 & 1.269 & 1.599 & \\
\hline$\because \quad 5 \quad \cdots \quad \ldots \ldots \ldots$ & 4.60 & .550 & 2.115 & 2.665 & \\
\hline “ $7 \ldots \ldots \ldots$ & 6.44 & .770 & 2.961 & 3.731 & \\
\hline " $\quad 8 \quad$ " $\ldots \ldots \ldots$ & 7.36 & .880 & 3.384 & 4.264 & \\
\hline $\begin{array}{llll} & 9 & 6 & \ldots \ldots\end{array}$ & 8.28 & .990 & 3.807 & 4.797 & \\
\hline * 12 " $\ldots \ldots \ldots$ & 11.04 & 1.320 & 5.076 & 6.396 & \\
\hline " 15 " $\ldots \ldots \ldots$ & 13.80 & 1.650 & 6.345 & 7.995 & \\
\hline " 18 " $\ldots \ldots \ldots$ & 16.56 & 1.980 & 7.614 & 9.594 & \\
\hline " 20 " $\ldots \ldots \ldots$ & 18.40 & 2.200 & 8.460 & 10.660 & \\
\hline \multirow{2}{*}{ Corn fodder, 1 lb............ } & .58 & .025 & .373 & .398 & \multirow[t]{7}{*}{$1: 14.9$} \\
\hline & 2.90 & .125 & 1.865 & 1.990 & \\
\hline $8 \cdots \ldots \ldots$ & 4.64 & .200 & 2.984 & 3.184 & \\
\hline $12 ، \ldots$ & 6.96 & .300 & 4.476 & 4.776 & \\
\hline $15 ، \ldots \ldots$ & 8.70 & .375 & 5.595 & 5.970 & \\
\hline 18 “ & 10.44 & .450 & 6.714 & 7.164 & \\
\hline $20 " \ldots \ldots \ldots$ & 11.60 & .500 & 7.460 & 7.960 & \\
\hline \multirow{2}{*}{ Corn stover, $11 \mathrm{lb} . \ldots \ldots \ldots$} & .60 & .017 & .340 & .357 & \multirow[t]{7}{*}{$1: 19.9$} \\
\hline & 3.00 & .085 & 1.720 & 1.805 & \\
\hline 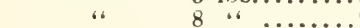 & 4.80 & .136 & 2.720 & 2.856 & \\
\hline 12 ، & 7.20 & .204 & 4.080 & 4.284 & \\
\hline $15 ،$. & 9.00 & .255 & 5.160 & 5.415 & \\
\hline $18 \approx \ldots$ & 10.80 & .306 & 6.120 & 6.426 & \\
\hline 20 " $\quad \ldots \ldots \ldots$ & 12.00 & .340 & 6.880 & 7.220 & \\
\hline
\end{tabular}


TABLE II - Continued

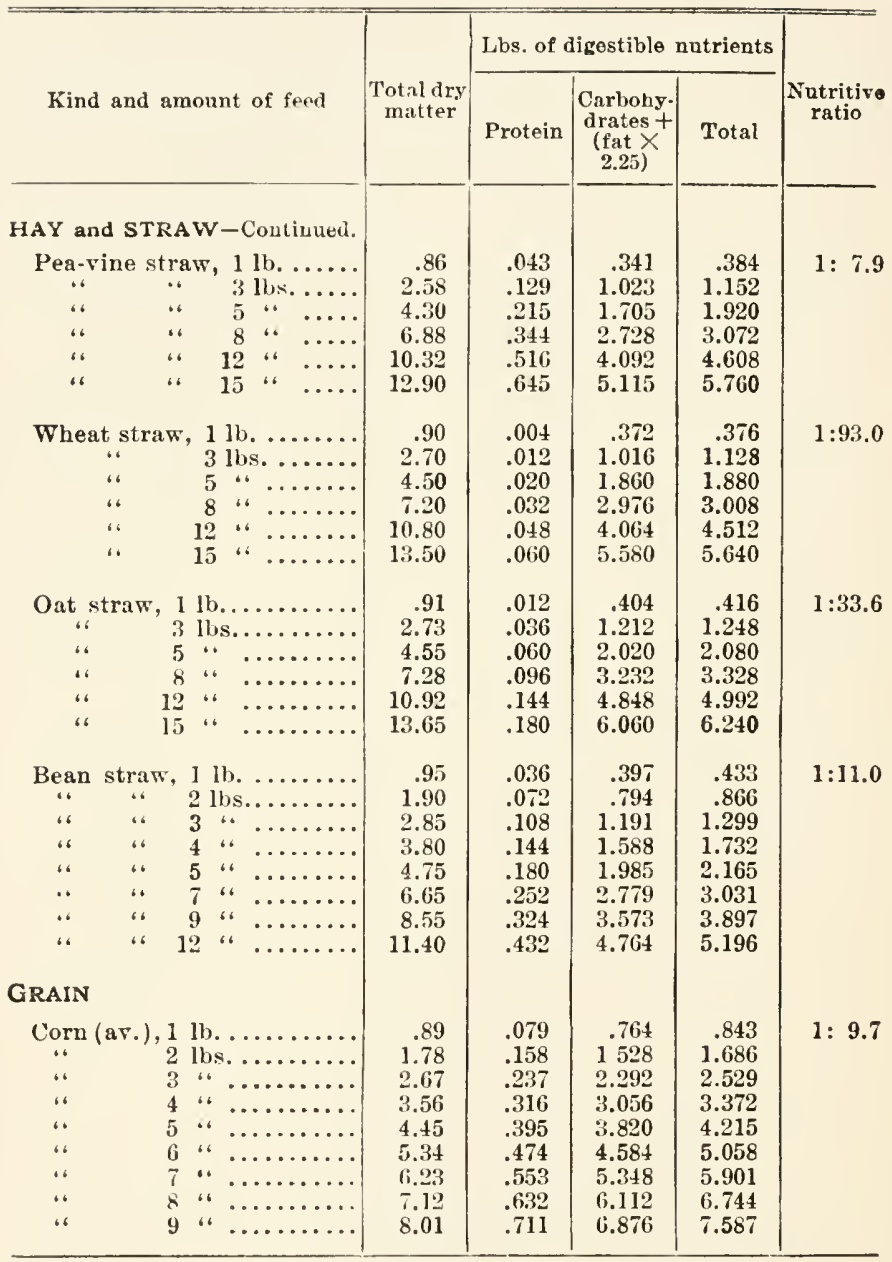




\section{TABLE II - Continued}

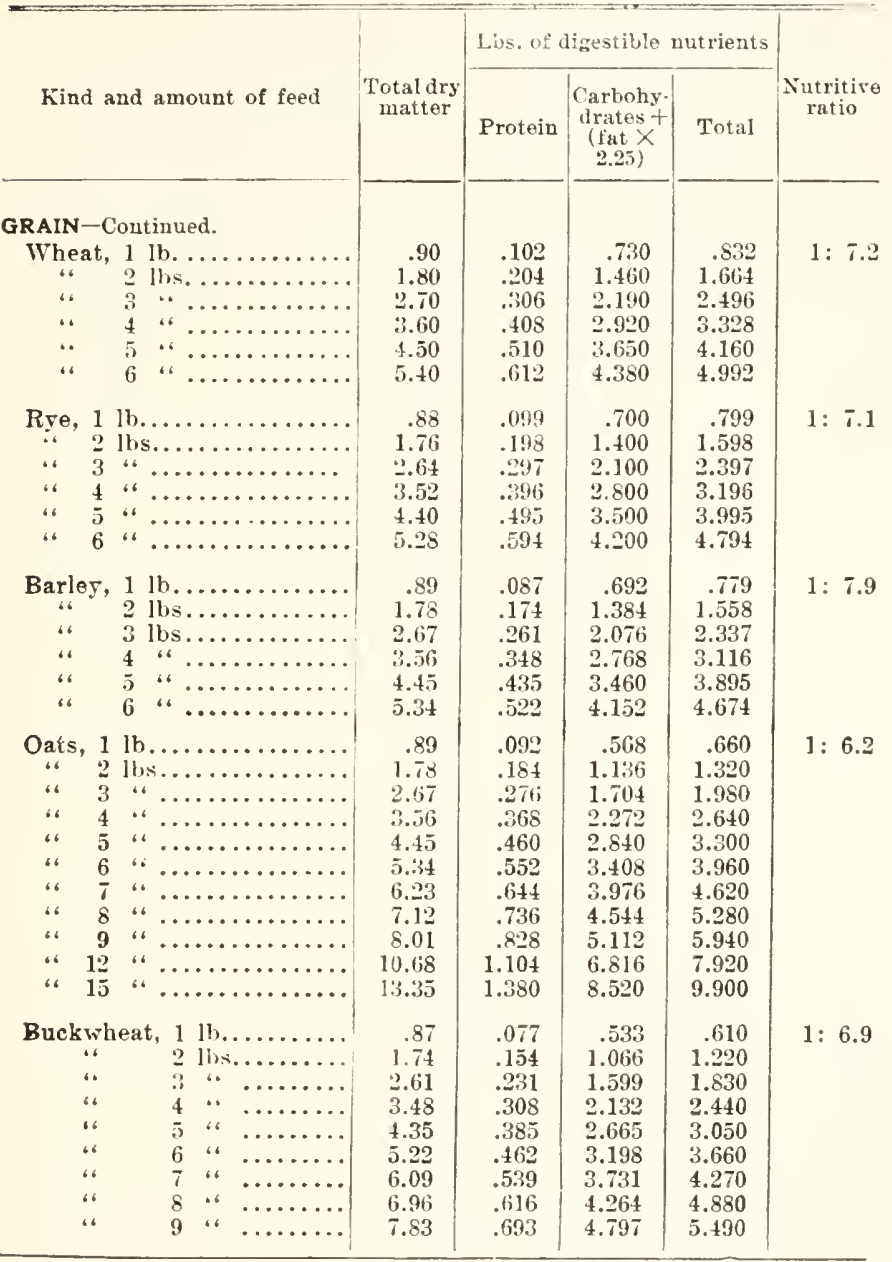


TABLE II - Continued

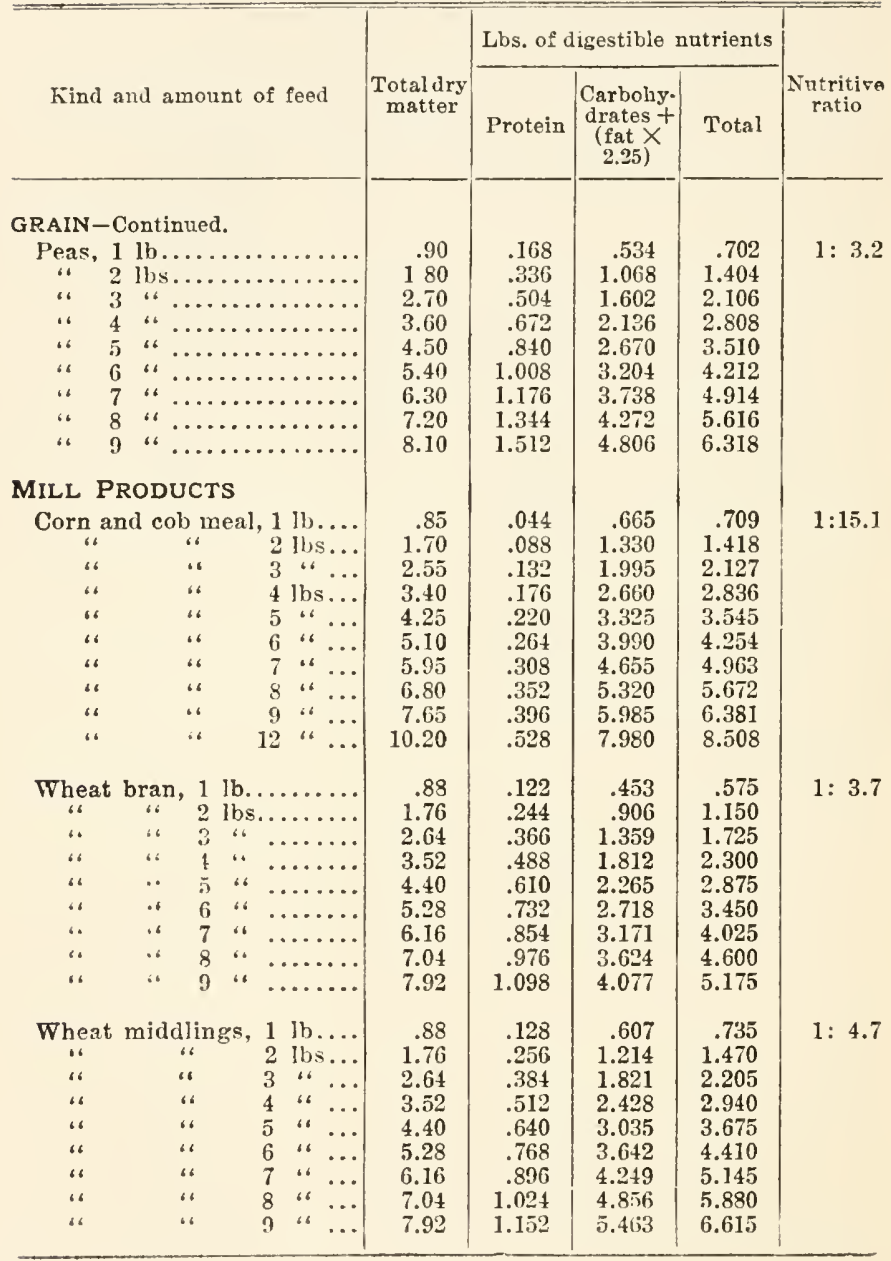




\section{TABLE II - Continued}

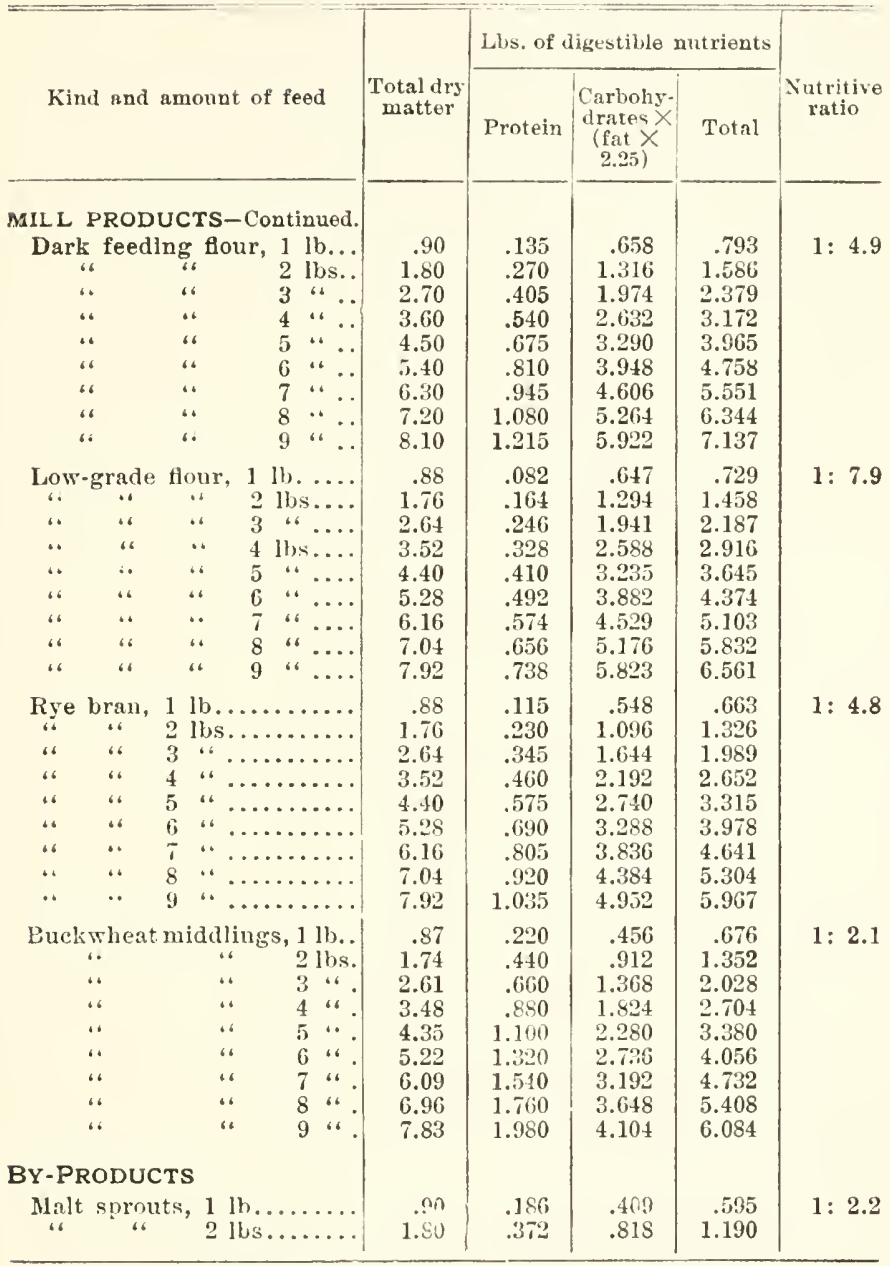


Table II.-Continued

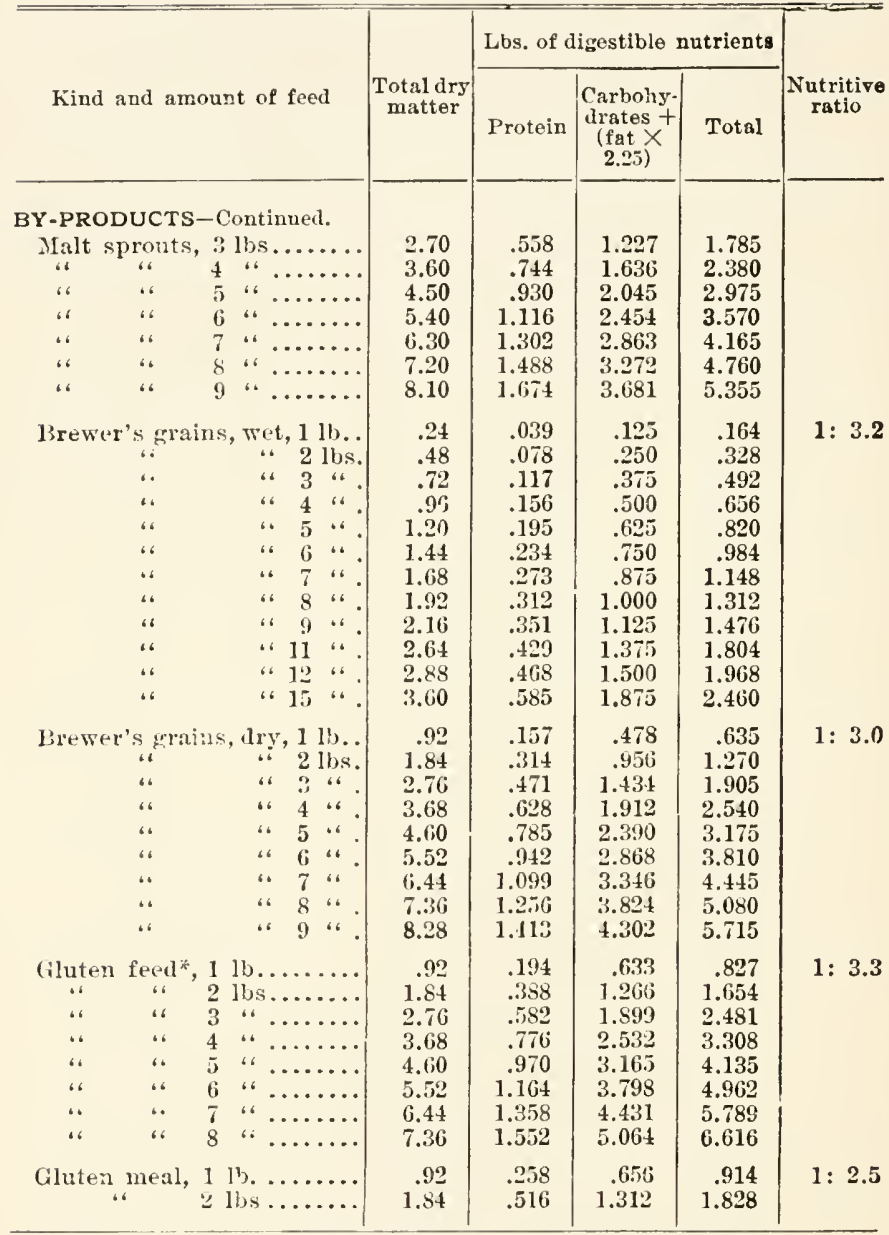

* F'rom Eulletiu of Information No. 1, Pennsylvania State College. 
TABLE II.-Continued

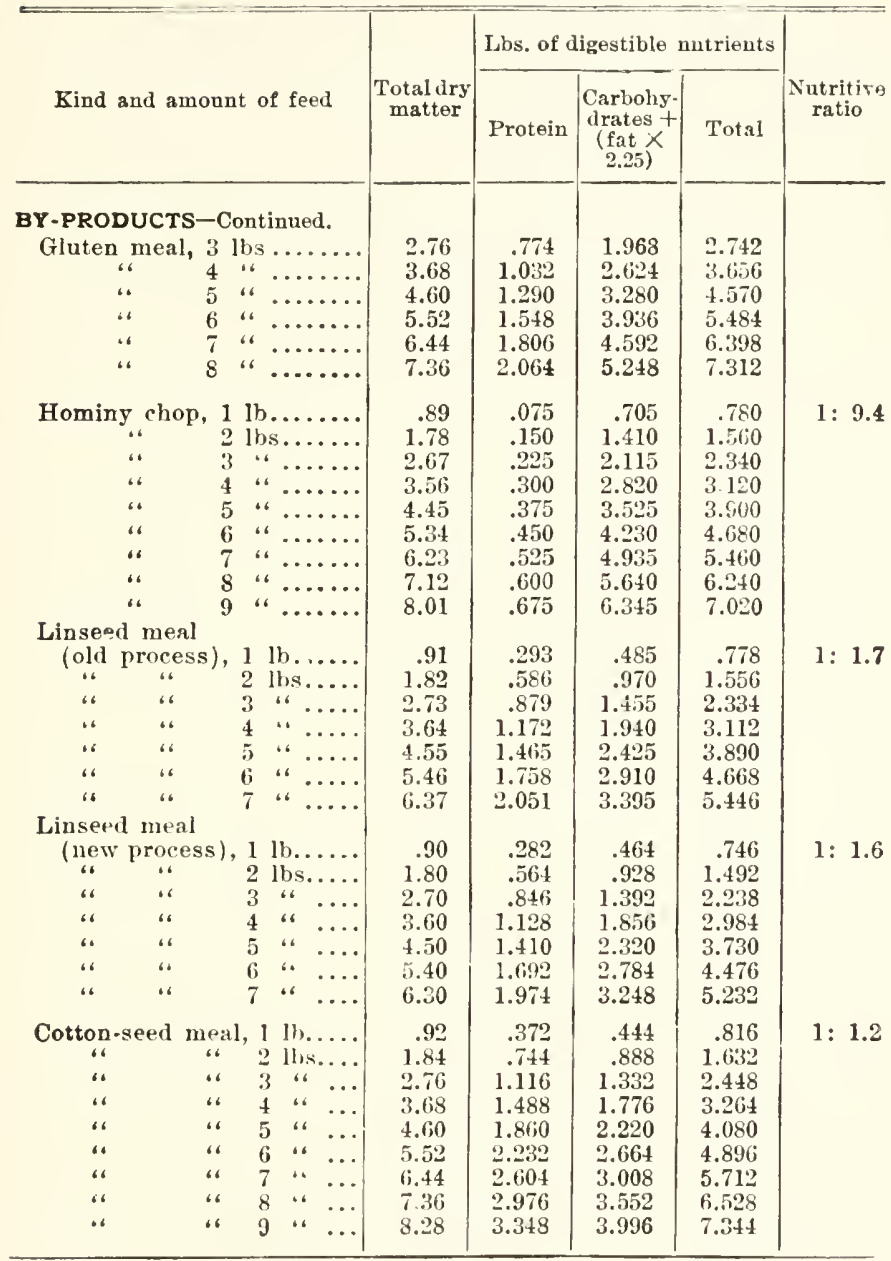


TABLE II - Continued

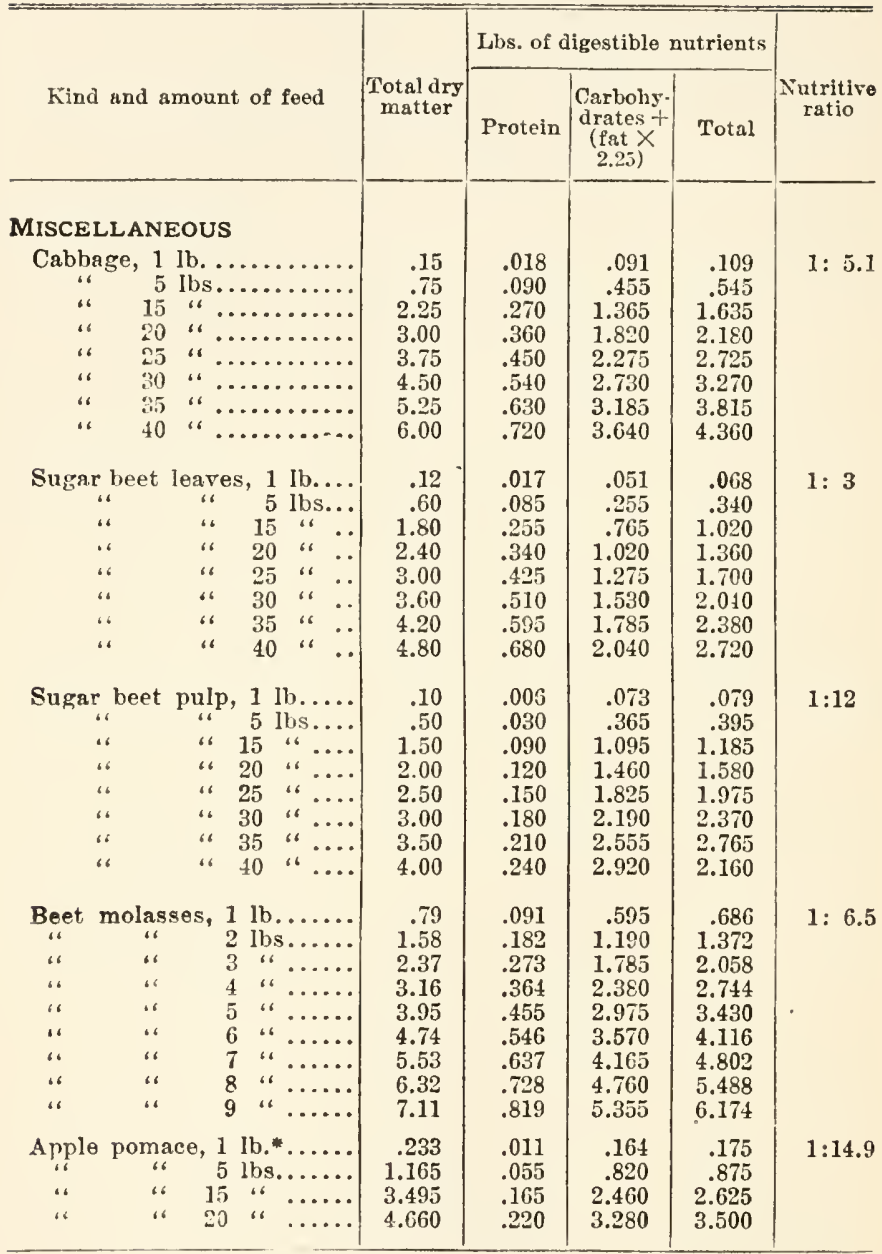


TABLE, II-Continued

\begin{tabular}{|c|c|c|c|c|c|}
\hline \multirow[b]{2}{*}{ Kind sind amount of feed } & \multirow[b]{2}{*}{$\begin{array}{l}\text { Totaldry } \\
\text { matter }\end{array}$} & \multicolumn{3}{|c|}{ Lbs, of digestible nutrients } & \multirow[b]{2}{*}{$\begin{array}{c}\text { Nutritive } \\
\text { ratio }\end{array}$} \\
\hline & & Protein & $\begin{array}{c}\text { Carbohy. } \\
\text { drates }+ \\
\text { (fat } \times \\
2.25)\end{array}$ & Total & \\
\hline \multicolumn{6}{|l|}{ MISCELLANEOUS-Continued. } \\
\hline Apple pomace, 25 lbs ...... & 5.825 & .275 & 4.100 & 4.375 & \\
\hline 30 " $\ldots \ldots$ & 6.990 & .330 & 4.920 & 5.250 & \\
\hline “ $\quad 35$ “ $\quad \ldots \ldots$ & 8.155 & .385 & 5.740 & 6.125 & \\
\hline " $\quad 40 \quad$ " $\quad \ldots \ldots$ & 9.320 & .440 & 6.560 & 7.000 & \\
\hline Skim milk, gravity, 1 lb... & .096 & .031 & .065 & .096 & $1: 2.1$ \\
\hline “5 lbs.. & .480 & $.15 \overline{5}$ & .325 & .480 & \\
\hline 8 " . . & .768 & .248 & .520 & .768 & \\
\hline $12 " \ldots$ & 1.152 & .372 & .780 & 1.152 & \\
\hline $15 " \ldots$ & 1.440 & .465 & .975 & 1.440 & \\
\hline $20 " \ldots$ & 1.920 & .620 & 1.300 & 1.920 & \\
\hline $25 ، \ldots$ & 2.400 & .775 & 1.625 & 2.400 & \\
\hline " 30 " & 2.880 & .930 & 1.950 & 2.880 & \\
\hline Skim milk, centrifugal, $1 \mathrm{lb}$. & .094 & .029 & .059 & .088 & 1: 2 \\
\hline $5 \mathrm{lbs}$. & .470 & .145 & .295 & .440 & \\
\hline 84. & .752 & .232 & .472 & .704 & \\
\hline 12 “. & 1.128 & .348 & .708 & 1.056 & \\
\hline 15 “. & 1.410 & .435 & .885 & 1.320 & \\
\hline $20 ،$. & 1.880 & .580 & 1.180 & 1.760 & \\
\hline $25 \lll$ & 2.350 & .725 & 1.475 & 2.200 & \\
\hline 30 “ & 2.820 & .870 & 1.770 & 2.620 & \\
\hline Buttermilk, 1 lb......... & .10 & .039 & .065 & .104 & $1: 1.7$ \\
\hline$" \quad 51 \mathrm{l} s \ldots \ldots \ldots$ & .50 & .195 & .325 & .520 & \\
\hline $8 "$ " $\ldots \ldots \ldots$ & .80 & .312 & .520 & .832 & \\
\hline $12 ، \ldots \ldots \ldots$ & 1.20 & .468 & .780 & 1.248 & \\
\hline $15 " \ldots \ldots \ldots$ & 1.50 & .585 & .975 & 1.560 & \\
\hline 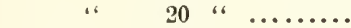 & 2.00 & .780 & 1.300 & 2.080 & \\
\hline 25 " $\ldots \ldots \ldots$ & 2.50 & .975 & 1.625 & 2.600 & \\
\hline " $\quad 30$ " $\quad \ldots \ldots \ldots$ & 3.00 & 1.170 & 1.950 & 3.120 & \\
\hline
\end{tabular}


TABLE III

Elements of Fertility in 1,000 Pounds of Various Feeds

\begin{tabular}{|c|c|c|c|c|c|c|c|}
\hline & $\begin{array}{l}\text { No. of } \\
\text { analy- } \\
\text { sis }\end{array}$ & 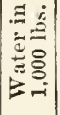 & $\begin{array}{c}\text { Ash in } \\
1,000 \\
\text { lbs. }\end{array}$ & $\begin{array}{l}\text { Nitro- } \\
\text { gen in } \\
\text { I, } 000 \\
\text { libs. }\end{array}$ & $\begin{array}{l}\text { Phos- } \\
\text { phorie } \\
\text { acid in } \\
1,000 \\
\text { los. }\end{array}$ & $\begin{array}{c}\text { Potash } \\
\text { in } 1.000 \\
\text { lbs. }\end{array}$ & $\begin{array}{c}\text { Esti- } \\
\text { mated } \\
\text { value } \\
\text { per } \\
\text { ton }\end{array}$ \\
\hline 1. I & 45 & 828 & 14.7 & 1.6 & 1.1 & 3.9 & $\$ 090$ \\
\hline 2. 1 & $\ldots \ldots$ & 467 & 16.05 & 2.8 & 1.65 & 6.25 & 150 \\
\hline 3. $\mathrm{B}$ & $\ldots \ldots$ & 755 & 16.7 & 2.7 & 1.8 & 5.05 & 138 \\
\hline 4. Red clov & 42 & 790 & 16 & 4.6 & 1.5 & 4.8 & 186 \\
\hline 5. Alfalfa, & 11 & 760 & 22.1 & 6.2 & 1.5 & 3.5 & 218 \\
\hline 6. Hun & 6 & 870 & 12 & 3.2 & .7 & 4.7 & 138 \\
\hline 7. C & & 779 & & 1.4 & 1.1 & 3.7 & 82 \\
\hline 8. $\mathrm{Po}$ & 197 & 750 & 1] & 1.4 & 1.6 & 5.7 & \\
\hline 9. Ma & & 872 & 12.2 & 1.7 & .9 & 3.8 & 90 \\
\hline 10. Bee & 68 & 820 & 8.1 & 1.7 & .8 & 3.7 & 88 \\
\hline 11. Ca & 63 & 870 & 10 & 1.2 & .9 & 2.6 & 65 \\
\hline 12. $\mathrm{T}$ & 69 & 143 & 4. & 4.4 & 5.0 & 14.1 & \\
\hline 13. Mix & 393 & 137 & 6 & 9.9 & 4.1 & 13.2 & 433 \\
\hline 14. $\mathrm{H}_{\mathrm{l}}$ & & 77 & & 7.2 & 3.5 & 0 & 350 \\
\hline 15. $\mathrm{R}$ & 178 & 170 & 6 & 10.8 & 5.5 & 7 & 520 \\
\hline 16. Al & 117 & 153 & & 17.6 & 6.1 & 9 & 708 \\
\hline with ears. & ... & 92 & 3 & 4.0 & 2.9 & $\Lambda$ & 264 \\
\hline 18. Col & & 150 & 4 & 2.7 & 3. & 16 & 257 \\
\hline 19. Pe & 53 & 136 & & 6.8 & 3. & 10 & $\begin{array}{ll}314 \\
\end{array}$ \\
\hline 20. I & 80 & 136 & & .64 & 2.2 & .3 & 94 \\
\hline 21. $\mathrm{O}$ & 55 & 145 & 5 & 1.9 & 2.8 & 17.7 & 238 \\
\hline 22. In & 149 & 130 & & 12.6 & 5.7 & 3.7 & 434 \\
\hline 23. W & 1,358 & 134 & 1 & 16.3 & 8.7 & 5.5 & 584 \\
\hline 24. $R$ & 257 & 134 & & 15.8 & 8.6 & 5. & 572 \\
\hline 25. Ba & 1,128 & 143 & & 3.9 & 7.9 & 4.8 & 504 \\
\hline 26. $\mathrm{Oa}$ & 560 & 123 & 3 & 1.7 & 6.9 & 4. & 516 \\
\hline 27. $\mathrm{Bu}$ & 20 & 141 & 27 & 12.3 & 6.9 & 3.0 & 434 \\
\hline 28. $\mathrm{Pe}$ & 118 & 140 & 28.1 & 26.8 & 8.4 & 10.1 & $\begin{array}{lll}9 & 16\end{array}$ \\
\hline 29. Cc & & 90 & & 7.0 & 5.7 & 4.7 & 290 \\
\hline 30. I & 93 & 132 & 5 & 9.5 & 26.9 & 15.2 & 924 \\
\hline 31. W & 24 & 126 & 2 & 4 & 13.5 & 7.4 & 76 \\
\hline 32. Ds & & 98 & 12 & 16 & 5.7 & 5.4 & 704 \\
\hline 33. Rye br & 230 & 125 & 46.0 & 18.4 & 22.8 & 14.0 & 846 \\
\hline 34. $\mathrm{Bu}$ & 5 & 156 & & & 4.2 & 12.7 & 482 \\
\hline 35. Bu & & 120 & 47 & 5.2 & 12.3 & 11.4 & \\
\hline 36. Ma & 12 & 120 & 75.1 & 29.7 & 17.4 & 19.9 & 1168 \\
\hline 37. Bre & 158 & 762 & 12 & 6.2 & 4.2 & .5 & 216 \\
\hline 38. Bre & 166 & 95 & 47.2 & 25.1 & 16.1 & 2.0 & 870 \\
\hline 39. Glu & & 86 & $7 ?$ & 41.2 & 3.3 & .5 & 1118 \\
\hline & & 89 & 22.1 & & 9.8 & 4.9 & 468 \\
\hline & & 89 & 61.0 & & 16.6 & 13.7 & 158 \\
\hline 42. Li & & 110 & 62.1 & 45.1 & 17.4 & 13.4 & 1540 \\
\hline
\end{tabular}


TABLE III-Continued

\begin{tabular}{|c|c|c|c|c|c|c|c|}
\hline & $\begin{array}{l}\text { No. of } \\
\text { analy- } \\
\text { sis }\end{array}$ & 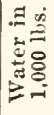 & $\begin{array}{c}\text { Ash in } \\
1,000 \\
1 \mathrm{bs} .\end{array}$ & $\begin{array}{c}\text { Nitro- } \\
\text { gen in } \\
1,000 \\
\text { lbs. }\end{array}$ & $\begin{array}{c}\text { Phos- } \\
\text { phorie } \\
\text { acid in } \\
1,000 \\
\text { lbs. }\end{array}$ & $\begin{array}{c}\text { Potash } \\
\text { in } 1,000 \\
\text { lbs. }\end{array}$ & $\begin{array}{c}\text { Esti- } \\
\text { mated } \\
\text { value } \\
\text { per } \\
\text { ton }\end{array}$ \\
\hline 43. Cotton-seed meal.. & 142 & 88 & 70.5 & 59.5 & 30.4 & 15.8 & $\$ 2082$ \\
\hline 44. Cabbage & 7 & 856 & 14.1 & 2.8 & 2.2 & 5.2 & 148 \\
\hline 45. Sugar beet leaves & 8 & 880 & 23.9 & 2.7 & 1.5 & 6.2 & 125 \\
\hline 46. Sugar beet pulp... & 16 & 898 & 5.8 & .96 & .2 & .4 & 32 \\
\hline 47. Beet molasses... & 35 & 207 & 106 & 14.5 & .5 & 56.3 & 916 \\
\hline 48. Apple ponace.. & 5 & 740 & 8.2 & 1.7 & .1 & .3 & 26 \\
\hline 49. Skim-milk, gravit & 96 & 904 & 7 & 49 & 2.1 & 2.0 & 174 \\
\hline 50. Skim-milk, centrifugal. & 7 & 906 & 7.4 & 4.6 & 2.1 & 2.0 & 165 \\
\hline 51. Bean straw ... & 6 & 53 & 69 & 11.4 & 2.1 & 18.4 & 504 \\
\hline 52. Turnips....... & & 905 & 8. & 1.8 & 1. & 3.9 & 94 \\
\hline
\end{tabular}

Analysis of Various Fertilizer Materials

\begin{tabular}{|c|c|c|c|c|c|}
\hline & \multicolumn{3}{|c|}{ In 1,000 lbs. } & \multirow{2}{*}{$\begin{array}{l}\text { Phos- } \\
\text { phoric } \\
\text { acid }\end{array}$} & \multirow{2}{*}{ Potash } \\
\hline & Witer & Ash & Nitrogen & & \\
\hline 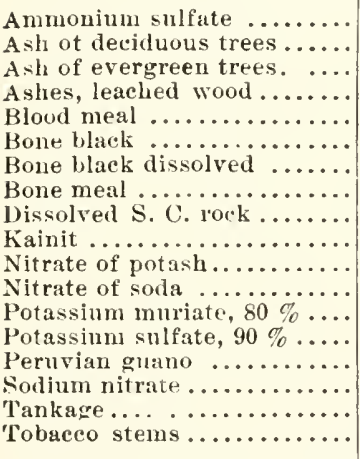 & $\begin{array}{c}40 . \\
50 . \\
50 . \\
302 . \\
134 . \\
46 . \\
\ldots \ldots . . \\
130 . \\
120 . \\
127 . \\
19.3 \\
14 . \\
11 . \\
2.2 . \\
150 . \\
26 . \\
100 . \\
180 .\end{array}$ & 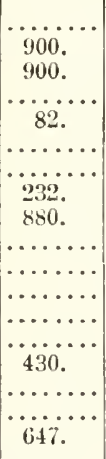 & 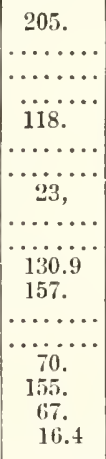 & 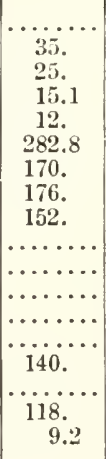 & $\begin{array}{c}100 . \\
60 . \\
12.7 \\
7 . \\
\ldots \ldots \ldots \\
\cdots \ldots \\
1 . \\
\ldots \ldots \ldots \\
128 . \\
451.9 \\
\ldots \ldots \ldots \\
527 . \\
499 . \\
33 . \\
\ldots \ldots \ldots \\
\cdots \ldots \ldots \\
28.2\end{array}$ \\
\hline
\end{tabular}


To illustrate how these tables may be used, we will examine a system of feeding which the writer observed recently in a certain section of New York. The section referred to is devoted almost exclusively to dairying, and timothy hay constitutes the greater part of the coarse fodder during the feeding season. Oats are about the only grain raised. Corn is purchased and ground with the oats, in about equal weights, to make "chop," which is fed with the hay. The cows will not vary greatly from 1,000 pounds live weight. While these cows are in full flow of milk in the spring before pasture is ready, they are fed about 20 pounds of hay and 8 pounds of chop per day. Turning to the tables, we find that 20 pounds of hay, 4 pounds of oats and 4 pounds of corn contain digestible nutrients as follows:

\begin{tabular}{|c|c|c|c|c|c|}
\hline & $\begin{array}{c}\text { Dry } \\
\text { matter }\end{array}$ & Protein & C. $\underset{\text { Fat }}{\text { H. aud }}$ & Total & $\begin{array}{c}\text { Nutritive } \\
\text { Ratio }\end{array}$ \\
\hline $\begin{array}{r}20 \text { lbs. hay } \ldots \ldots \ldots \ldots \ldots \ldots \\
4 \text { lbs. oats.............. } \\
4 \text { lbs. corn } \ldots \ldots \ldots \ldots \ldots\end{array}$ & $\begin{array}{r}17.40 \\
3.56 \\
3.56\end{array}$ & $\begin{array}{l}.560 \\
.368 \\
.316\end{array}$ & $\begin{array}{l}9.300 \\
2.772 \\
3.056\end{array}$ & $\begin{array}{l}9.860 \\
2.610 \\
3.372\end{array}$ & \\
\hline 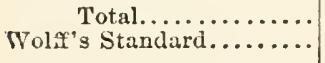 & $\begin{array}{l}24.52 \\
24.00\end{array}$ & $\begin{array}{l}1.244 \\
2.5\end{array}$ & $\begin{array}{l}14.628 \\
13.4\end{array}$ & $\begin{array}{l}15.872 \\
15.9\end{array}$ & $\begin{array}{l}1: 11.7 \\
1: 5.4\end{array}$ \\
\hline
\end{tabular}

Upon comparison of the nutrients furnished by this ration with Wolff's standard as given in Table I, it is discovered that while the dry matter and total nutrients are not far out of the way, the protein is much too small, the carbohydrates 
and fat are somewhat too great, while the nutritive ratio is far too wide.

This result might readily have been foreseen had we paused a moment to note the nutritive ratio of each of the three foods entering into the ration. They are, timothy hay, 1:16.6; oats, 1:6.2; corn, 1:9.7. Neither of them is as narrow as the standard, and it is impossible to combine them into a ration that is approximately balanced. As corn is a purchased product, the natural suggestion is that the corn should be replaced by some food having a high proportion of protein, or, in other words, a very narrow nutritive ratio. Consulting the table, it is found that among such are linseed meal, cottonseed meal, gluten feed, malt sprouts, buckwheat middlings, etc. As buckwheat middlings is a New York state product and can readily be put in stock during the winter, it is suggested to substitute it for the corn in the ration. Again taking the figures from the table, we have:

\begin{tabular}{r|r|r|r|r|r}
\hline & $\begin{array}{r}\text { Dry } \\
\text { matter }\end{array}$ & Protein & $\begin{array}{r}\text { C. H. and } \\
\text { Fat }\end{array}$ & Total & $\begin{array}{c}\text { Nitritivo } \\
\text { Ratio }\end{array}$ \\
\hline 20 lbs. timothy hag...... & 17.40 & .560 & 9.300 & 9.860 & \\
4 lbs. oats............ & 3.56 & .368 & 2.272 & 2.640 & \\
4 lbs. buckwheat mid's.. & 3.48 & .880 & 1.824 & 2.704 & \\
Total............... & 24.41 & 1.808 & 13.396 & 15.204 & $1: 7.4$ \\
\hline
\end{tabular}

While this ration is much improved over the previous one and will produce a much freer flow 
of milk, it is still too wide to produce the best results. If the timothy hay is reduced two pounds and two pounds of cottonseed meal put in its place, we get:

\begin{tabular}{|c|c|c|c|c|c|}
\hline & $\underset{\text { matter }}{\text { Dry }}$ & Protein & C. $\underset{\text { Fat }}{\text { H. and }}$ & Total & $\begin{array}{c}\text { Nutritive } \\
\text { Ratio }\end{array}$ \\
\hline $\begin{array}{r}18 \text { lbs. timothy hay........ } \\
4 \text { lbs. oats................ } \\
4 \text { lbs. buckwheat mid's.. } \\
2 \text { lbs. cottonseed meal .. }\end{array}$ & $\begin{array}{r}15.66 \\
3.56 \\
3.48 \\
1.84\end{array}$ & $\begin{array}{l}.504 \\
.368 \\
.880 \\
.744\end{array}$ & $\begin{array}{r}8.370 \\
2.272 \\
1.824 \\
.888\end{array}$ & $\begin{array}{l}8.874 \\
2.640 \\
2.704 \\
1.632\end{array}$ & \\
\hline Total.............. & 24.54 & 2.496 & 13.354 & 15.850 & $1: 5.3$ \\
\hline
\end{tabular}

This ration corresponds very closely to the standard, and while the purchase of the cottonseed meal will add somewhat to the expense, still it is the experience of careful feeders that the increased production will abundantly pay for thus securing a proper balance to the ration.

The same result may be obtained by using other feeding stuffs having a narrow nutritive ratio. The question is likely to be raised, Which of the various feeding stuffs offered in the market may most economically be used in supplementing the home-grown foods to produce a balanced ration? This question is best answered by formulating properly balanced rations containing each of the foods under consideration; and by assigning the actual market value per pound to each of the constituents of the ration, its cost is readily ascertained and the cheapest may be selected. 


\section{CHAPTER VIII}

\section{ACCOUNTS WITH THE FARA HOUSEHOLD}

IT will be necessary to say something more of Farm Household. It has been thought best not to complicate the accounts already set forth by introducing accounts with Farm Household, since they need to be treated specifically. This third division of accounts, which includes Farm Household and necessary explanations to keep such account, does not imply that no inventory is to be taken of other belongings, but rather that a fuller one be made than has yet been set down.

First, make a detailed inventory of personal farm property. It need not necessarily be copied in a book, though it would be well to have it done. Then make out an inventory of household goods, with valuation of each article or group of articles affixed. Follow this with the statement of the value of the farm and of all amounts receivable and payable. With such an inventory it will be possible to know present worth. Such inventories would better be taken in late winter or early spring, when there is likely to be freedom from pressing work. In justice to one's family, to 
creditors and to oneself, such inventories should be taken annually. A summary of such inventory might be approximately as follows (for form of itemized inventory, see Chapter II) :

\section{Inventory taken March 1, 1901}

\section{SUMmaRY}

Farm, personal property................... $\$ 2,600$

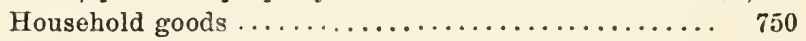

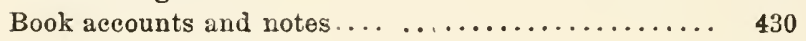

Farm, eighty acres................... 4,000

Less mortgage .....................\$1,000 $\$ 7,780$

Less amounts payable .................. 300

Net assets........................ $\frac{\$ 1,300}{\$ 6,480}$

In order to simplify fanm household accounts, now that an inventory has been made, let the wife or daughter take charge of this part of the bookkeeping. The proprietor and his workmen draw on Farm Household for their subsistance, hence Farm Household will have a credit for board furnished. This implies that Wheat Field, Live Stock, etc., will be charged not only with the value of the labor of the workmen, but for their board also. The simplest way out of the complex condition is to assume a price for each workman, which shall include board. This will furnish a credit to Farm Household and result in having a definite price for labor performed for the various 
divisions or accounts. Such arrangement will assist materially in simplifying the accounts and in getting at the true cost of raising the various crops and of caring for the live stock. To illustrate:

Let it be assumed that the workmen are paid $\$ 20$ per month-a higher price may be assumed for the proprietor; let it also be assumed that board and room are worth $\$ 13.80$ per month, or approximately $\$ 3$ per week. It must also be assumed that ten hour's constitute a day's worksome days may be longer, some shorter-and that twenty-six working days constitute a month.

A summary of the above would be as follows:

Wages, one month ...................... \$20 00

Board, one month.................... 1380

$\$ 3380$

260 hours' labor, at 13 cents per hour ........ \$33 80

While the above statements are assumed, they may serve well to show how transactions under similar conditions may be treated in order that a definite amount may be charged for labor to Corn Field, Poultry, etc.

In like manner the price per hour may be set for the proprietor:

Wages, one month...................\$38 00

Board, one month..................... 1400

$\$ 5200$

260 hours' labor, at 20 cents per hour.........\$52 oc 
Let it now be assumed that all supplies for household are charged up, including indoor help, cash, flour, chickens, groceries, clothing, furniture, etc. In addition to this account, which embraces all outgoes and all incomes, a Personal Expense account should be kept with and by each individual old enough to record the items. Such accounts will reveal not only what the maintenance cost of each individual of the household is, but also the cost of maintaining that part of the family which is not engaged in productive industry in the fields and barns. The only credit to Household will be the board bills of those engaged in productive industry on the farm. Such credit will be smaller than the outgo. The deficit must be made up from some other source, such as wages of the proprietor and his children.

This does not imply that the wife has not earned her board and raiment. But it does enable the farmer to determine with a good degree of accuracy the profits or losses of the farm operations proper. If the children are employed in gainful work on the farm, their time should be charged up to the various farm accounts according as the work is performed. Such wages and the liberal wages allowed the proprietor, added to the profits of the farm, should maintain the family in comfort and leave a modest surplus.

Having all the facts at hand, one can judge 
fairly accurately whether it would be better to pay house-rent in town, work by the day or month, as work presented itself, buy all food supplies from the grocery, or whether it would be better to remain on the farm. In this connection, of course, it would have to be decided whether to rent the farm, or to sell it and put the money at interest. One could now approximate the cost of living in town, the income from labor performed for other people and the income from the money loaned which formerly was invested in safe realty.

If accounts are kept on the farm as they should be, it can further be determined whether the earnings of the wage-workers of the family are enough to maintain them and the remainder of the family which do not contribute directly to the income; or whether the profits of the farm and its equipment - the invested capital-must be added to the wage income in order to maintain and educate the family.

\section{A CHAT WITH THE FAHILY}

In the "Fertility of the Land," the first pages were devoted to a "Chat with the Young Farmer." The author has decided that it is best to have his present chat with the family somewhat privately, in the. last pages, so that the family secrets will 
not go out at the front door; and, therefore, he has placed this confidential talk at the close of "Farm Accounts" instead of at the beginning.

It is assumed that the principles which should govern in keeping accounts set forth in the preceding pages have been mastered by hard and persistent study, and that some form of accounting has been adopted, and that accounts have been kept for at least one year.

The wife and some of the children are really gainful factors, but usually silent partners, unless accounts are kept with the household. They may add much to the common fund, but have little or no voice in the use or investment of the wealth which they have helped to accumulate. Let it be remembered that the family is a cöoperative company, each working for the benefit of all. The capital stock is composed largely of good will and love; therefore, there should be frequent meetings of the stockholder's, that the business may be fully discussed and plans laid for future operations. For convenience in carrying on the business, one person should be the financial head - the president. In order that business may not be delayed or blocked, the president should, if emergencies arise, hold the balance of power in deciding large affairs.

Let us attend one of the meetings of this com. 
pany of, say, six stockholders. Three of the children are old enough intelligently to discuss the company's affairs. The wife makes a report of the expenditures of the month. She calls attention to the need of a larger dining table, the desirability of increasing the number of flyscreens. She reports what the cost of them will be. She tells where the old table is needed in some other room. She refrains from saying that "Mrs. Smith has such a table as is needed, although the Smiths are no better off than we are." This good housewife reports to the company her plans for paying for these additional comforts. The daughter, Mary, renders her account of personal expenses for the month. These are discussed and plans made for her expenditures for the following month.

The large, solid boy, John, renders his account. His expenditures for the month consist of one pair denim overalls 50 cents, one straw hat 50 cents. John evidently has a carriage in mind, and if that acre of potatoes "pans out" all right, he will get it in the fall without calling on father for any money. His sister sees the point, and concludes she will make over one of her old summer dresses and defer the purchasing of a new gown. One can tell what is in her mind-she is in sympathy with John's scheme and makes this sage remark, "A made-over dress is often like 
warmed-over Christmas turkey,-better than it was at first."

"Bud," the little philosopher of the family, says, "I hain't had nothin' this month 'cept my board-got lots of old clothes, must wear 'em out, 'cause they hain't no good for school clothes. Good enough when I pick strawberries or potato bugs." But Bud has not told all his story. Listen carefully as he whispers in his mother's ear: "I am saving my strawber'ry money to buy a hat for father on his birthday. Hasn't had a new one for two years, and his old one is just shocking; if he weren't my father, I'd be ashamed of him."

The good wife of the farm is sometimes the last one to be remembered. She must look forward to the final footings of all accounts at the end of the year. She must be provident, selfsacrificing; manage to keep her house clean and tidy and herself neatly dressed when away from home. She may not bear the heaviest physical burdens, but she must of necessity bear the greatest responsibility. She should be fully acquainted with all outgoes and incomes, all plans for future operations, all prospects of increasing or diminishing incomes. She must take forethought for the time when the children should go to the academy or the college. She must forestall the additional demands which will be 
made when the children unite their destinies with those reared in other households. While she is thinking and planning for all this, we wonder whether her husband has neglected to keep accounts not only with farm, but account of the debt he owes to his wife. Has' he writ down large somewhere in his memory the hour, the day and the year when he put himself under most sacred obligations, - when he became a debtor? Has he cast up this account yearly to see whether he had any credits to place over against that debtor charge which as yet stands unbalanced by an equal credit charge?

Is he as mindful of the debt he owes to his wife as little Bud is to the debt of love which he owes to his father, and which he proposes to liquidate? There are many accounts which should be balanced besides those with corn and cattle. In all these pages and those that follow, the attempt is made to impress upon the reader the unhappy effects of carelessness, - carelessness in conducting business, carelessness in discharging duty to other members of the honsehold, and, above all, carelessness in rembering benefits received. A careless memory tends to produce ingratitude and selfishness.

Of course one's gratitude is due first to one's family, but all broad-minded persons have, or should have, many friends from whom benefits 
are constantly being received. The value of these benefits cannot be set forth in an account book, therefore the greater necessity of taking a kindly interest in the welfare of others. Our world is just as large as we make it. Interest may be centered largely in self or in "Me and my wife, my son John, and his wife, us four and no more," or it may be as extended as our knowledge and as genuine as the interest taken in one's family.

As has already been stated, logically, there is no debit without a credit. Learn to remember one as religiously as the other. In brief, learn to keep accounts. Keep them in double entry. So far as possible make them balance. Where they do not balance, make this entry: By balance, love and good will. 


\section{PART II-RURAL LAW}

\section{CHAPTER IX \\ PROPERTI, DEEDS AND CONVEYANCES}

1. REAL AND PERSONAL PROPERTY, AND DISTINCTIONS BETIVEEN THEM

P'roperty is any thing or right that can be legally owned. It is of two classes, real and personal, and the rules relating to each are radically different. The differences between these species of property should be carefully borne in mind by the farmer.

Real property, or realty, may be said to include the actual soil itself, and everything permanently affixed to or imbedded in the soil; and ownership of realty carries with it the surface of the land and all above to the heavens and below to the center of the earth. If this were borne in mind it would dispose of a very prevalent but fallacious idea in regard to the law of trespass in relation to fishing, which is of much interest to the farmers' boys: this is the idea that there can be no trespass on water, but that actual contact 
with the soil itself is necessary. For instance, if a stream runs over the land of $A$, then upon the land of $B$, and there forms a pond, and the latter chooses to prevent boating or fishing thereon, the idea is held that by starting above the land of B and nowhere touching his soil, persons may come down the stream in a boat upon that portion of the stream or the pond overlying B's land, and fish there. Of course the idea is absurd when we bear in mind that the ownership of land includes not merely the solid surface, but all above it as well, and that to cross these boundaries on, above or below the surface is a trespass.

(See Chapter X, post.)

Real property includes, and a deed of land carries, therefore, all minerals imbedded in the soil, all water percolating through the soil, ice upon streams or ponds above the soil, all natural products - as trees and grasses and crops, while standing - all will pass under a deed, though not named. (See article on Removal of Crops, page 167, post.) Of course, houses and permanent erections upon the land become part of it, as, indeed, very frequently do many articles of personal property only temporarily affixed to the soil. These additions are called fixtures.

Personal property embraces every thing or right capable of being owned that is not real prop- 
erty. It includes chattels, goods, notes, bonds, debts, rights of action, etc. Any species of real property, as stone, minerals, trees, etc., upon separation from the soil itself, becomes under all ordinary circumstances personal property and subject to its law. Therefore, in making a sale of such property, or a contract in relation thereto, the reader must determine whether the subject is to be considered as a part of the land and unsevered from it, or whether the contract contemplates by its terms a severance from the soil. If the former, then it is a sale or contract relating to land and must be by deed, or a contract for its sale must be written, no matter what the value. If the latter, a contract for its sale need not be written unless it is of the value of fifty dollars or more, as is hereinafter explained.

The differences between these two kinds of property are, briefly: Realty goes to the heirs, while personalty goes to the next of kin of a decedent. These may or may not be the same persons. A wife has, in many states, a dower right of a life-interest in one-third of her husband's realty, which he cannot deprive her of by deed or will. But he may by sale, will or gift deprive her of any interest in his personalty; though, if he do not do so, she will be entitled to a share in that, also, upon his death. 


\section{DEEDS}

Probably by far the most important document in ordinary business transactions is the deed by which one acquires title to his home or his farm. The only ways to acquire real estate are by deed, by will, by descent, or by act of law. There are certain deeds that may be acquired by process of the court. Such deeds should always be submitted to the family lawyer, in order that he may determine whether due process of law has been had.

The most common deeds of real property are the warranty deed, so called, and the full covenant deed. The former warrants to defend the title to the property against all comers, and is ordinarily sufficient. It differs from the full covenant deed, however, in this - that, in order to recover from the grantor or maker, it is necessary to show an actual ouster (by some one claiming title), while the full covenant deed gives the right to proceed against the grantor the moment any flaw in the title appears. A warranty deed, in other words, necessitates a defense of title, relying upon the warrantor in case of defeat in the courts of law or otherwise. A full covenant deed, on the other hand, places the purchaser in position to proceed against the grantor the moment his title is assailed by a valid claim. It goes 
without saying, therefore, that the full covenant deed is the better to take. Another form of deed is what is known as the quit-claim deed, in and by which the grantor simply releases all claim which he may have in and to the premises deeded, and may covenant against any act of his own with reference to the property. A quit-claim deed contains no warranty of title. In many cases such a deed is absolutely good, but it should never be taken except upon the advice of legal counsel.

A deed is not necessarily a formal document. Any instrument which shows in language fairly clear the intent of one party to sell certain lands, and the intent of the other party to buy, which is commonly done by stating how much he is to pay, or stating it to be on consideration of one dollar, and which complies with the rules laid down as to contracts, is sufficient. It must be signed and sealed by the grantor and (generally) his wife, if he has one; if not, he should be described as unmarried. It should be duly acknowledged before a notary, although, if the signature be duly acknowledged before a subscribing witness, an affidavit may subsequently be made by such witness, which will entitle the deed to be recorded. In some states a deed need not be under seal, but sealing it never does any harm.

It is very necessary for safety to record a. 
deed in the office of the county clerk; otherwise subsequent instruments might be recorded ahead of one's deed, and, by the law of most of the states, would take precedence, as deeds and mortgages of real property must be recorded in the office of the clerk of the county where the property is located, or they will be void as against any subsequent purchaser or encumbrancer of the same property in good faith and for value. Record, moreover, is a prime safeguard against inconveniences arising from the loss of the deed and all of the accidents liable to occur in its possession.

It is a fact that a deed of property may be made upon the proper blanks by any person of intelligence. When a considerable amount is involved, however, it is unsafe to take a deed which has not been passed upon by some attorney in whom the purchaser has confidence. It is not a question of fraud-even your best and most loyal friend may ignorantly sell to you real estate to which he may have no title. A good lawyer can always detect these deficiencies and save you perhaps no end of annoyance and possible litigation by a careful investigation of the title and a thorough examination of the deed of conveyance.

There is a provision in nearly all states requiring sales of land to be by written instrument. These requirements are generally about as fol- 
lows: No interest in lands other than leases for a term not exceeding one year, nor any trust or power relating to lands, can be created, granted, assigned, surrendered or declared unless by act or process of law, or by a deed or conveyance, in writing, subscribed by the party creating, granting, assigning, surrendering, or declaring the same, or by his lawful agent thereunto authorized in writing; but this does not affect the acquiring of real property by will.

\section{ABSTRACTS OF TITLE}

It is unsafe for any person to take a deed of or mortgage upon property without an abstract of title, which is usually made by the clerk of the county. Abstracts are, however, frequently made by lawyers; and, at any rate, in large transactions where the abstract is complicated, it should always be passed upon by an attorney.

An abstract of title is a brief account of all the documents upon which title is based, and of all judgments, mortgages and instruments which in any way relate to such title as the same are recorded in the office of the county clerk.

Evidences of title include deeds, wills, decrees of the court, judgments, judicial sales, sales by officials authorized by law, acts of the legislature or congress, etc. 
Abstracts of deeds should show:

1. Names of grantor and grantee. If any grantor was a married man, his wife's name. If there is no statement that the grantor was unmarried, a careful abstractor should procure proof of that fact and annex it to the abstract.

2. Date of deed; brief synopsis of the character of the grant, and whether absolute or conditional.

3. Names and residences of parties and of executors, guardians, officials and the like, where such parties appear and have anything to do with the conveyance.

4. Any other recital in the deed which materially affects the title.

5. The description of the property in the original deed upon which title is based in full and any variation in subsequent deeds. All reservations or burdens upon the land, as rights of way, etc.

6. Consideration for which the deed is given. If the deed is executed by an attorney, the abstract should show that his power of attorney is recorded and unrevoked, and that his principal was alive when the deed was executed.

Care should also be taken as to signatures, acknowledgments, etc., and a notation made by the abstracter as to each conveyance, that in these particulars the deed is correct; or if not perfect in any of these particulars, the fact should be noted. 
Abstracts should show, as to wills:

1. Date of death of testator.

2. Date of probate of will and name of executor and any decree or order affecting him or his power.

3. Any charge made upon the estate in the nature of legacies, annuities, etc.; the judicial settlement of the estate, if any, or the reason such settlement has not been made.

4. The particular clause or portion of the will relied upon for title in full.

5. All codicils affecting the portion of the original will relied upon for title.

6. Anything which might act as a partial revocation of the will, as the birth of a child subsequent to the making of the will, or such a change in the nature of the estate as might affect the title.

When title is derived from sale upon execution, or in fact from any judicial sale, the proceedings leading up to the sale should be carefully examined and the principal steps carefully noted in the abstract.

All facts not a matter of record should be properly authenticated by affidavit or official certificate aunexed to the abstract.

All encumbrances should be noted, with their date and character. These include judgments in the county where the property is situated and judgments in the United States Courts, judgments 
from other counties, mortgages, dower rights, pending actions or litigations, taxes, mechanics' liens, homestead exemptions, and, in fact, every kind of lien or encumbrance affecting in the slightest degree absolute and perfect title to the property.

There are few abstracts made where some flaw is not found, though many are easily corrected at the time; whereas if time were allowed to run on without knowledge it might be impossible to make the correction, or it might, at least, entail serious trouble, with possible costly and vexatious litigation. In fact, much of the litigation in this country has arisen from neglect of this sort, where a few dollars paid to an attorney at the start would have saved hundreds of dollars in the end.

The matter of always requiring an abstract is not a question of lack of confidence or mistrust. The most honorable man in the world may unwittingly sell you property upon a worthless title. $\mathrm{He}$ bought it in the same way. Then, later on when you find it out it may be, by reason of death or accident or other cause, a very troublesome and costly thing to remedy; whereas, if you had demanded an abstract it might have been arranged in an hour at the time. An abstract, therefore, is not so much to guard against a man's dishonesty as against his carelessness. 


\section{LEASES}

A lease may be defined, for our purpose, as an instrument whereby one person lets real property to another. Of course, there may be leases of personal property, but we shall not consider them here. It is always very much better to reduce a lease to writing, though a verbal lease for a term not exceeding one year is good in most states, and this is so even though the term is to begin at a future time. In New York, and in many other states, a lease for a term of more than three years must be acknowledged and recorded as a deed would be, and if this is not done the owner of the property may sell it to a third party, who knows nothing of the lease, and the tenant can not hold the property for the balance of his term.

The following form of a lease of a farm on shares will be found to include most of the matters which generally arise in connection with such a lease; but it must be carefully borne in mind that the agreement of the parties may embrace matter's not covered by this form, and all such matters should be incorporated into the lease and not left to rest in the verbal agreement of the parties: 
This Indenture, made this . . . day of . . . . . . , 19. . , between JoHn Brown, of the town of . . . . . . . . . , New York, of the first part, and JонN Jones, of the same place, of the second part,

Witnesseth, That the said party of the first part has hereby let and rented to the party of the second part, and the party of the second part has hereby hired and taken from the party of the first part, the farm of the party of the first part known as the "Hill Farm," situated on the highway leading from the town of to the town of and in said town of ................. and containing about two hundred acres, with the appurtenances, for the term of one year from April 1, 1903, upon the terms and conditions following:

The said party of the second part hereby covenants and agrees, to and with the party of the first part, that he will occupy, till, and in all respects cultivate the premises above mentioned during the term aforesaid, in a husbandlike manner, and according to the usual course of husbandry practiced in the neighborhood; that he will not commit any waste or damage, or suffer any to be done; that he will keep the fences and buildings on the said premises in good repair, reasonable wear thereof and damages by the elements excepted; and that he will deliver to the said party of the first part, his heirs, executors or administrators, or to his or their order, one equal half of all the proceeds and crops produced on the said farm and premises aforesaid, of every name, kind and description,- 
to be divided on the said premises, in the mow, stack or half-bushel, according to the usual course and custom of making such divisions in the neighborhood, and within a reasonable time after such crops shall have been gathered and harvested.

It is further agreed between the parties hereto that the party of the first part shall provide one equal half of all seed or seeds necessary to be sown or planted on said premises, and pay all taxes and assessments upon the same; that the party of the second part is to do, or cause to be done, all necessary work and labor in and about the cultivation of the said premises; that he is to have full permission to inclose, pasture, or till and cultivate the said premises, so far as the same may be done without injury to the reversion, and to cut all necessary timber for firewood, farming purposes and repairing fences; and that he is to give up and yield peaceable possession of the said premises at the expiration of his said term.

The party of the second part is hereby given the privilege of renewing this lease upon like terms for three periods of one year each, upon giving written notice of his desire so to do at least sixty (60) days before the expiration of the preceding period.

In witness whereof, the said parties have hereunto set their hands and seals this . . . day of . . . . 1903.

[Have the execution of this lease acknowledged before a Notary Public or Justice of the Peace, if possible, and, if not, have witnesses to the signatures.] 
Great care should be taken to include in every lease all the things either party is to do, for there are but few things which will be implied by law as a part of the agreement. Indeed, it is usually said that the only agreements which the law will imply against a landlord are, that he shall assure the tenant that he has power to lease the premises to him, and that the tenant shall have quiet enjoyment of them, and when the lease is of a house, that it shall remain in substantially the same condition until the tenant comes into possession, while the only agreements implied against the lessee are to pay the rent and to use the premises in a reasonable and proper manuer. All else must be expressed in the lease.

A tenant should be very careful to surrender the premises immediately upon the expiration of his term. If he does not do so, the landlord may construe his holding over, even though it be for a few days, as an election to take the premises for another year, or such shorter term as the premises were previously hired for, upon the same terms as before; in which event the tenant would be bound to rent for such new term and pay the rent as before. On the other hand, if the landlord does not choose to consider the holding over as an election to take a new term, he may consider it a trespass and begin proceedings to put the tenant off the premises. These 
proceedings are now much simplified and can usually be carried through in a very short time.

\section{TENANT'S RIGHT TO REHOVE CROPS AT END OF TERM}

In this connection, the law recognizes a great distinction between those products of the soil which are the result of man's planting and annual labor and cultivation, and those which are natural products and growths of the soil, not requiring annual cultivation, or which, though planted by man in the first place, do not require periodical effort in the way of cultivation. The first class includes grains, regetables, etc., which are the result of annual or periodical labor in planting, sowing and cultivation, such as potatoes, corn, wheat, most garden vegetables, etc., and may, for our purpose, be known as "crops." The second class includes those products which are not included in the first class, that is-trees, clover, hay and fruit-such as apples, pears, plums, etc., for, though some of these may have been planted by man in the first place, they do not generally require annual replanting or such continued periodic cultivation.

The first class is regarded as personal property and subject to the rules thereof as to sale, etc. The second class is regarded as part of the land 
itself, and subject to the rules relating to real property. Of course, as is indicated elsewhere in this work, property belonging to the second class, upon severance from the soil, may become personalty; and crops of the first class, while ungathered, may pass with the land, under a deed thereof; but, generally speaking, the distinction is as stated above. Therefore, it is the rule that a tenant, upon the expiration of the term for which he holds the land, is not entitled to take with him that which is part of the land itself, that is, any of those products which are included in the second class named above, such as furt, hay, etc., unless the same has been, before the expiration of the tenancy, gathered or severed from the soil so as to lose its character as real property.

But those products which are part of and included within the first class, that is, most vegetables, rye, wheat, oats, corn, cotton, etc., are not regarded, as a general thing, as part of the soil; and so in some cases a tenant, upon the expiration or termination of his term before the harvest of crops which he has previously planted, is even allowed to harvest and remove the same. The rule may be stated thus: When a tenant holding for an uncertain term or period-as a tenant for the life of himself or of another person, or at the will of the owner-plants a crop before the end of his term, and that term ends without 
his fault before the crop has been harvested, he or his personal representative is entitled to the crop so planted, and to the right of ingress and egress for the purpose of caring for and harvesting the same. But if he occupies the land for a certain or definite term, so that the time of its termination was known to him before he planted the crop, or if his tenancy was terminated by his own fault, as for failure to pay rent, etc., then he is not entitled to the crops planted by liim, but they revert, with the land, back to its owner.

With regard to the removal of manure by a tenant at the end of his term, or during the term, it may be said that the law, as well as good husbandry, requires a tenant to put back upon the farm, or leave upon it, all manure made from crops derived from the land. However, if the manure is made from grain, etc., brought to the farm from elsewlere, it is not required to be left upon the farm, but may be disposed of by the tenant as he may choose. In this latter case, however, he must not mix the manure which he is entitled to carry away with that which he is not entitled to carry away, or he may lose it all. Manure is generally held to be real estate and not personal property, though it has been held to be personalty when piled upon a platform or in the barn-yard and not yet spread upon the fields. 


\section{CHAPTER $\mathrm{X}$}

TRESPASS AND WATER RIGHTS

\section{TRESPASS}

A person who, without permission, hunts upon the lands of another, whether he goes upon such lands in search of game or goes on in pursuit of game already started, is guilty of trespass; and this is so, regardless of the absence of signs forbidding hunting. However, the generally accepted rule in America is that one who kills or captures wild game, even while trespassing upon the lands of another, is, nevertheless, the absolute owner of the game and will be liable to the owner of the premises for the trespass to the land only.

\section{ANIMALS}

One who finds animals of another trespassing upon his lands may seize and keep them until the damage done is satisfied. This matter is now governed by statutes which provide summary methods of appraising the damage done and satisfying the same by the sale of the animals. A similar summary method of disposing 
of estrays is also generally provided by the statutes of other states. (See Fences, Chapter XII.)

One keeping a vicious dog, either as owner or' harborer, and knowing its vicious propensities, does so at his own risk, and is liable for practically all injuries occasioned by it, and if the owner or harborer of a dog is shown to know that the dog had bitten some one previously, he will be charged with knowledge of its vicious propensities. Many states have special statutes regulating the payment of damages caused by the killing of sheep by dogs, and in New York and some others it is only necessary to show to certain town officials that the sheep have been killed by dogs and prove their value, whereupon the amount of damage will be paid to the owner out of the town funds raised from the taxation of dogs.

\section{WATER RIGHTS}

In many localities the value of water is such that special laws have been framed and passed regulating water rights. In general, however, it is the law that the riparian owner, - that is, the one whose lands are bounded or crossed by a stream, - has the right to the use of the water of that stream for all domestic or farm purposes, or other reasonable purposes, as turning a mill, and the like, and that no man may so 
divert the water from the stream as to interfere with that right.

It is impracticable here to go into the matter of the rights of mill-owners. For our purpose it is sufficient to say that, beginning at the source of the stream, each riparian owner, in his turn, has the right to the use of the water for domestic purposes. He must not divert it or pollute it or interfere with it in any way except to take what is necessary for his reasonable needs, nor may he materially interfere with the natural flow. No person has a right to divert any water by sluice, ditch or otherwise from its natural channel to the damage of another; and, if he does, he is liable for all damage caused by such diversion, except that one may change the channel of a stream upon his own lind if he returns it again to its channel so as not to affect the flow on another's land; and one may withhold a reasonable amount of water from a stream permanently, but must not withhold so much as to materially reduce the flow below, though it has been held, and rightly so, that one may use all the water of a stream or spring necessary for his ordinary wants, such as drinking, washing, cooking, and for stock, even though it leave none for the lower proprietor.

Most of these rules apply equally well with sluices and ditches upon the highways. A com- 
missioner has no right to divert surface water from its natural channel and carry it along by ditch or sluice to some other point before turning it upon the adjacent land. He must so arrange his sluices as to carry the water in its natural channel, or, in case of surface water gathered in the highway, he must carry it to the nearest natural channel instead of flowing it upon the adjacent lands. A failure to do this renders the town liable for all damage to the land or to growing crops.

\section{DRAINAGE}

In case a person has wet lands in his farm, it is very generally provided that he may bring a proceeding to authorize the construction of a ditch across any adjoining lands, for the purpose of draining the wet places. The proceedings in such a case are quite technical, and a lawyer should be consulted before any steps whatever are taken. It has been held, in some states, that this proceeding constitutes a taking of private property for private use, and is, therefore, unconstitutional; but, as a general rule, some waycan be found to force a ditch or drain across the adjoining lands, and the benefit is often so great that the matter is well worth investigating. 


\section{CHAPTER XI}

HIGHWAYS AND ROADSIDES

\section{USE OF ROADSIDES}

In most country highways the fee of the land usually remains in the adjacent owner, the only right of the public being the right to its free and uninterrupted use for highway purposes. It follows, therefore, that, subject to this use by the public, the adjacent owner has title to the soil and all above or beneath it; that sand and gravel banks, quarries, coal, etc., may be used by him so long as public travel is not hindered. No other person may remove even a shovelful of earth without becoming a trespasser as much as if he took it from the garden of the adjacent owner. It has been held, however, that the overseer of highways may remove earth and gravel in the repair of the highway, even though he transports it a considerable distance to another section of the road; though it has also been decided in some states that this will not be allowed.

So, too, the timber growing along the highway, as well as all fruits, nuts and other prod- 
ucts of the soil belong to the adjacent owner. However, the timber may be used for bridges and other betterments of the road under the same rules as apply to the removal of soil.

In this connection it may be well to say that the adjacent owner has an undoubted right to make any reasonable temporary use of the side of the road, as for the piling of lumber or logs, or for wagons and other farm implements, so long as he does not interfere with the free use of the highway; but he must remember that he is liable for any damage which may be suffered by the public thereby, and that a practically continuous obstruction is unreasonable and not permissible.

\section{IMPASSABLE HIGHWAYS}

We may also note, at this point, the rule that when a highway is temporarily obstructed $\mathrm{Ol}^{\circ}$ impassable and there is no other way by which the traveler may go without unreasonably delaying his journey, and the obstruction is such as cannot be readily removed without material delay, he may then go outside of the highway and upon the private lands adjacent, to pass around the defective or obstructed portion of the highway; but in so doing he must refrain from doing any unnecessary damage. 
III. LAWS AFFECTING TRAVEL ON HIGHWAYS

The "law of the road" in this country is that drivers of vehicles meeting on the highway shall turn to the right of the worked portion. They must, to use a common expression, give half of the road.

In this country there is no general rule as to which side a traveler is obliged to turn out on when allowing another to pass from behind, and it has been said to be doubtful whether there is any duty to turn out at all in such a case, though it is probably the better rule for the foremost driver to yield as much of the road as possible on request, though if it be inexpedient at that particular point to yield any portion of the road, he may defer it until reaching a more convenient spot; and, in any event, the person passing from the rear is liable for any damage done to the person passed, unless the latter brought it on by his own carelessness, and he in his turn is liable for any damage which may occur by reason of his refusal or neglect to give free passag' $\theta$ to the team behind him. Of course "the law of theroad" as to vehicles does not apply when two pedestrians, or a pedestrian and a vehicle, meet or pass. It is provided in New York by the highway law, that:

(a) Whenever any persons, traveling with any 
earriages, or riding horses or other animals, shall meet on any turnpike road or highway, the persons so meeting shall seasonably turn their carriages, horses or other animals to the right of the center of the road, so as to permit such carriages, horses or other animals to pass without interference or interruption.

(b) Any carriage, or the rider of a horse or other animal, overtaking another shall pass on the left side of the overtaken carriage, horse or other animal. When requested to do so, the driver or person having charge of any carriage, horse or other animal, traveling, shall, as soon as practicable, turn to the right so as to allow any overtaking carriage, horse or other animal, free passage on his left.

(c) In turning corners to the right, carriages, horses or other animals shall keep to the right of the center of the road. In turning corners to the left, they shall pass to the right of the center of the intersection of the two roads.

(d) Any person neglecting to comply with or violating any provision of this section shall be liable to a penalty of five dollars, to be recovered by the party injured, in addition to all damages caused by such neglect or violation.

It must be borne in inind that all these rules as to the use of highways are subject to a very important limitation, to the effect that every per- 
son who uses a highway, whether he be on foot or in a vehicle, or however he may be traveling, must always use reasonable care to avoid harming another and to prevent another harming him. This rule is so strong that one may, and many times must, ignore entirely the so-called "law of the road" if, by so doing, he will avoid the threatening harms. In other words, one may not arbitrarily rely upon the "law of the road" in times when it is evident that harm will come to him or to another if he does so, but upon all such occasions he must use all reasonable means to avoid the harm. In the case of street railway cars, not only must he do this, but the courts have held that, in addition, it is his duty, if he is driving on or near the track, to look back with reasonable frequency to note any approaching car, and that his failure so to do may constitute contributory negligence, barring his recovery for any damage which may occur.

No person has a right umreasonably to obstruct, even for a moment, the free use of the highway by others, or to impede any legal rate of speed at which they are traveling So, too, no person has a right to drive stock along a highway without suitable attendance, or to drive or lead vicious animals without taking every reasonable safeguard.

In New York, vehicles propelled by steam or 
other mechanical power have, by recent amendments to the statutes, been given full rights to the highways, although what are known as traction engines and all other vehicles or engines propelled by steam which develop twenty-five horse-power or more may not legally use the highways unless preceded for an eighth of a mile by some competent person, to give warning of their approach.

Notwithstanding the right to use a motor vehicle upon the highway, it is the undoubted duty of the driver to so use it as not to restrict or endanger its use by the public; as, for instance, he should stop or slow up when approaching a frightened team, and not exceed the legal rate of speed, and in all things conform to the "law of the road."

In New York the statute requires an automobile to stop upon the signal of an uplifted hand from the driver or rider of a restive horse, or the driver of stock, and wait until it has been passed.

It is the duty of the town officials to maintain a good and passable highway, with bridges of sufficient strength to carry all ordinary travel. In some states the carrying strength of such bridges is fixed by law. In New York the statute fixes the carrying capacity at four tons, and a person going upon a highway bridge with 
a greater load does so at his peril, and is liable for all damages that occur.

A town is liable for any damage which may occur from failure to use ordinary care to keep its roads and bridges in passable condition, but is excused in cases of extraordinary snow or flood or some other cause beyond its control, known in the law as an "act of God." When highways or bridges are defective it is the duty of the town, through its proper officers, to make repairs at once or as soon as may be, and it is liable for any damage which may be suffered by any person by reason of its neglect or refusal so to do, if the officials knew, or by reasonable diligence might have known, of the defect and have then delayed an unreasonable time before remedying it.

The law does not require that every highway shall be of the same standard of excellence, but it must be such a highway as is suitable for the needs of the public in that locality and under the surrounding conditions.

\section{SIDE-PATHS}

We may also note the gradual spread of the so-called "side-path" laws, which provide for the construction and maintenance of paths along highways for the use of cyclists. These laws 
have been found to be of great benefit to country districts, as well as to cities, as they provide a very convenient mode of access to cities by the country people.

The procedure for obtaining the construction of a side-path is not at all cornplicated, and an application to the local county judge or the president of the local wheelmen's association, will usually result in an investigation, and, if a favorable report is made, in the construction of the desired side-path. Attention is simply called to the very general existence of these laws, and the procedure is left for the local attorney or wheelmen.

\section{WATERING-TROUGHS AND SHADE TREES}

In some states the establishment of wateringtroughs is obligatory upon highway authorities. In New York the policy has been to encourage their establishment, as well as the planting of shade trees. With this in view, it is the law that any person maintaining a watering-trough, with the approval of the highway commissioner, shall be allowed a rebate equivalent to three days' road tax per year. Any person planting shade trees, under like approval, is allowed, at the end of the first year, twenty-five cents upon his road tax for each living tree so planted. These trees may be planted seventy feet apart if elms. They 
may be removed at any time the same as other trees. Unless the highway is made hard by graveling or macadamizing, shade trees often injure the roadway by shading, which hinders evaporation and hence prolongs the period of muddy roads.

VI. GUIDE-BOARDS

In New York it is the duty of the highway commissioner to establish and maintain suitable guideboards at the four corners of all highways, and a penalty is provided for neglect to do so after written request of five resident taxpayers of the town or twenty resident taxpayers of the county.

A similar law maintains in most other states, but there appear to be few laws so honored in its breach as this. Commissioners of highways may also place mile-posts upon the highways.

\section{WEEDS ALONG HIGAWAYS}

In New York and many other states the overseer of highways is required, by statute, at least twice a year, once before July first and again before the first day of September, to eut all noxious weeds along the highway under penalty of a fine of ten dollars for each offense. It is made the duty of the commissioner of highways upon his own motion, or upon complaint of any citizen, 
to bring suit for this penalty against any overseer of highways who neglects this duty, and if he neglect or refuse to bring the action for thirty days the complainant may himself bring the action.

A like duty of cutting weeds is also placed upon the occupants of lands bounding on highways; this is required once between June fifteenth and July first, and once between August fifteenth and September first of each year.

To the farmer there are few more important laws upon the statute books affecting agriculture, yet here again the law, notwithstanding its directness, is, in some localities, practically a dead letter; all of which leads to the reflection that we do not, in all cases, so much need new laws as we need the energy to see that the many good laws upon the statute books for our benefit are enforced.

However, many of the noxious weeds of the roadside are not destroyed by cutting, such as burdocks and the narrow- and broad-leaved yellow docks. Though the main top may be cut off with the scythe, lateral branches come out and fruit in sufficient abundance to keep the land seeded. These and other biennial and perennial plants should be dug out before the seed-stalk appears. In one little city the burdocks have been cut regularly for the last ten years and yet they are quite as much in evidence as when the task of clearing the back streets was begun. 


\section{CHAPTER XIL}

\section{$L E G A L \quad F E N C E S$}

\section{WHAT A LEGAL FENCE IS}

Most of the states have fixed by statute what shall constitute a legal fence. They vary from a height of four feet in New Hampshire and Massachusetts to six feet in South Carolina. Generally, they may be of any material sufficient to form a barrier. In many states barbed wire is prohibited, while in some of the southern and western states, as in Texas, barbed wire is made a legal fence by statute, while in the state of Washington in order to be legal a barbed wire fence must carry a top rail of wood.

In New York one may, of course, use barbed wire for a division fence when the adjoining owner consents to its use; it is also provided that, when the adjoining owner refuses his consent, a division fence may still be built with four strands of barbed wire and a sufficient bar of wood at the top, the size of the top bars, the posts and supports and their distances apart to be prescribed by the fence-viewers. Any person building such a fence without consent is liable 
for all damages occasioned by it. When such a fence is out of repair to such an extent that it is unsafe, it must be repaired immediately by the owner. This law does not apply to railroads, which, while they are allowed to use wire for fencing their rights of way, may not use barbed wire for that purpose. In regard to the duties of a railroad, it may be said that now it is generally required to fence and keep fenced both sides of its right of way sufficient to keep out cattle, horses, sheep and hogs, and is liable for all damage caused by failure so to do. It is also obliged to make farm crossings and gates wherever necessary.

The majority of states fix four and one-half feet as the legal height of fence, and the usual height in New York is four and one-half feet. In this state, however, each township at its annual town meeting may prescribe what shall be a legal fence. It will thus be seen that the legal height of fences may vary from time to time, and may vary also in the various townships in the county. The assessors and commissioners of highways perform the duties of fence-viewers.

\section{LINE FENCES}

The board of fence-viewers in New York state may also pass upon the question of line fences. 
Under the law, each adjoining owner is obliged to build and keep in repair one-half of the line fence between himself and his neighbors through all lands, and in case they cannot agree the fenceviewers may make the proper division. The division once made, each party becomes responsible for his share. Should he not build a fence, or should he build one that does not conform to the requirements of a legal fence, or should he allow it to become out of repair, he is responsible for all damage which may accrue to his neighbor, and must suffer, without recovery, for all damage done him by his neighbor's stock by reason of such defective fence.

By giving written notice to the adjoining owner, a person may in New York let his lands "lie open," which means that he chooses not to build his share of the line fences, and, therefore, will not hold his neighbor liable for any damage done by the latter's cattle coming onto the land lying open, nor will he let his own cattle upon the neighbor's land through the land so lying open.

In New York, fences destroyed by accident must be repaired within ten days after written notice so to do by adjoining owner, or the adjoining owner may himself do so at the expense of the one failing to obey the notice to repair.

When lands in New York border on navigable waters the owners must fence to low water-mark; 
when bounded by a line in non-navigable waters, the owners must agree on the location of a division fence along the water, or the fence-viewers will locate it on one bank or the other and prescribe the method of maintenance. A substantially similar rule applies in most of the other states.

When fruit or nut trees overhang a line fence, the owner has no right to enter upon the lands of his neighbor and gather the crop. The proper procedure is to ask permission to enter and gather the fruit which has fallen beyond the line. If this permission be refused, there are two courses open to the one on whose land the trunk of the tree stands: he may enter and gather the crops and stand liable for trespass; or, it has been said, he may sue his neighbor who has refused permission to enter for a conversion of the fruit and so recover its value. If the neighbor takes the fruit from the branches which overhang his land, he is liable for conversion. But the neighbor, upon the other hand, may cut down the soil upon the line, severing the roots of the tree. He may also cut off, upon the line, all projecting or overhanging limbs. When such a tree grows upon the line, the rule of law is that each adjacent owner takes what falls upon his side of the line. All these conditions follow from the rule that one owning the surface of the land 
also owns upward to the heavens and downward to the center of the earth.

Line fences cause so much dispute and hard feeling that every farmer should inform himself fully respecting the legal complications that are likely to arise from any course of action. Statutes vary so much in different states that no full advice can be given in a book like this. The farmer must remember that the line fence question is regulated by law and not by what he considers to be justice in any given case. The law attempts to reach the average condition, but in doing so it may work injustice to the individual. This result is likely to follow the application of the present New York law. No man, in justice, should be compelled to fence against his neighbor's stock any more than he should be compelled to house or feed it. Yet the law compels one to do this, since it allows him no redress if he omits to fence and the neighbor's cattle trespass on him. If a man grows only fruit, he needs no fence. If he is compelled to fence his land in order to protect it from trespass, he is by that much contributing to his neighbor's welfare, with no return to himself. The fruit-grower does not need or want property in fences, yet his neighbor can compel him to invest in such property. This may seem to violate a fundamental principle of common law that every 
man should care for his own, and that no man should be compelled to purchase property that he does not desire. Extracts from the New York law follow:

Each owner of two adjoining tracts of land shall make and maintain a just and equitable portion of the division fence between such lands, unless one of such owners shall choose to let his lands lie open to the use of all animals which may be lawfully upon the other's land and does not permit any animals lawfully upon his premises to go upon the lands so lying open. (The Town Law, Section 100.)

If a land owner wishes to allow his lands to lie open, he must serve a written notice to that effect upon the adjoining land owners, and thereafter such adjoining land owners shall not be liable for any damage done by any of their animals going upon the lands so allowed to lie open. The owner of any lands so allowed to lie open may have the same enclosed by giving written notice to that effect to adjoining land owners, and shall refund to such adjoining owners his equitable portion of the value of any division fence made and maintained by them; or, if no fence has been so made, he shall build and maintain his proportion of such division fence. (id. Section 101.)

If disputes arise as to the liability to maintain division fences, any two fence-viewers named, one by each party, may decide the matter. (id. Section 103.)

Any person who shall neglect to contribute to the erection or repair of a division fence, shall be liable to the party injured for all damages which two fence-viewers shall determine to have accrued by such neglect, and if such neglect shall continue beyond one month after written request to make or repair the fence, the injured party may make or repair it and recover its value, with costs, from the one who is in defanlt. (id. Sections 105 and 108.)

Barbed wire may not be nsed for line fences without consent. (id. Section 109.) 


\section{ROAD FENCES}

Road fences in New York, and in many other states, are no longer obligatory, as stock running wild upon the highway is regarded as trespassing, and the owner of such stock is subject to penalties for its trespasses. It should, however, be remembered that the public has the right to use the highway for driving stock and that the owner of land along an unfenced highway cannot recover for damage done by stock in transit along: such highway, when accompanied by suitable drivers or attendants, without the fault of the latter.

We cannot leave the subject of road fences without calling attention to the fact that in some states there are express provisions for "live fences" along highways. These provisions are usually to the effect that the commissioners of highways will give written permission to any one whose land borders upon a highway, to move his fence out a distance sufficient to allow the growing of a hedge, which shall afterward become the highway fence at that point. The fences are usually allowed to remain out for a considerable period of time, often as long as ten years, in order to allow the hedge to grow to a sufficient height and density to render unnecessary any other fence. It is not generally allowable to set out 
fences in this mamner on both sides of the road at the same time.

This method of improving the roadsides and beautifying the country has usually met with such favor, and often leads to such satisfactory results, that it bids fair to be adopted in many parts of the country. In most instances it requires only a suggestion to the local representative to induce the introduction of a bill in the state legislature looking toward its adoption.

IV. INCORRECT LINE FENCES MADE LEGAL BOUNDARY BY LAPSE OF TIME

A man may become the owner of real property not his own originally, by what is known as adverse possession of the same for the requisite period. This is often decided where line fences have been erroneously erected and after a lapse of time the parties injured by the incorrect location endeavor to correct the same. If a man actually enclose the land, or part thereof, belonging to another, and claim the land enclosed by the fence as his own, and take actual possession of it as such, for the required period-frequently twenty years-and maintain open, adverse, notorious and exclusive possession during that time, his rights as owner of such land will become complete. If, however, he erect the fence through 
mistake, upon the land of another, not claiming the land enclosed up to the fence, but merely claiming the land to the correct boundary, whatever it may be found to be, he acquires no rights which will prevail against the true and original owner. If adjoining owners agree upon a dividing line, and actually claim and occupy the land on each side thereof for the necessary period, that will become the legal boundary. After that, the formerly incorrect boundary becomes established as the legal one, and the former owner cannot maintain an action to recover land lost to him by it. But if, by mistake, they decide on a line as the true boundary, not intending to claim anything beyond such boundary, the agreement upon the line does not affect their lights.

Only a general discussion is possible here; there are many rules which the scope of this work makes it impossible to treat. It may, however, be remembered that in most, if not all these cases, the rules are the same as to acquiring lands by changes in fence lines, as they are with regard to acquiring lands by adverse possession in any other way. One may not acquire a part of a highway by moving his fences out unless he does so to such an extent as actually to obstruct travel; that is, so far as practically to close the road. On the other hand, by so doing, he may become liable to a prosecution for nuisance. 


\section{CHAPTER XIII}

\section{CONTRACTS}

\section{IN GENERAL}

By far the most important branch of the law, to those who peruse these pages, is the subject of contracts, under which head comes every sort of binding legal agreement between man and man, as well as all agreements with corporate bodies and the like. A contract has been wisely and ably defined as "a meeting of two minds." In other words, it is not generally possible to have a valid contract or agreement between two or more parties unless there is a perfect understanding between them as to just what is contemplated by its terms, though there are some cases of rather uncommon occurrence in which the fact that one party has mistaken the matter under consideration is held not to excuse him from doing what he agreed to do. Each party must assent in some way to every essential part of its contents.

Legal verbiage is not an essential element of a contract, although, of course, like a piece of farm machinery, the better the finish the more desirable the production. 
The following may answer as a form for a great variety of the simpler agreements and contracts which arise every day in the ordinary transaction of business.

Memorandum of Agreement made this . . . . day of . ., 19 . by and between John Doe, of Ithaca, N. Y., party of the first part, and Charles Roe, of the same place, party of the second part.

Witnesseth, that for and in consideration of . . . . . . dollars (if other or different consideration, express it) to him in hand paid, the receipt whereof is hereby confessed and acknowledged and of the covenants and agreements hereinafter expressed, the party of the first part covenants and agrees

(Here insert just what he agrees to do as above suggested.)

And in consideration of the premises the party of the second part covenants and agrees

(Here insert the thing or things which the second party agrers to do.)

In witness whereof the parties have hereunto set their hand and seals the day and year above written.

Witness: (Signed) JoHN Doe. [L. S.] Charles Roe. [L. S.]

(Signed) James Smith.

A witness is not necessary, but if convenient it is better to have the agreement witnessed by a third party. The witness should ask each party if he acknowledges the execution, signature and 
seal (which in New York, and many other states, may be a scroll or the letters "L. S.," as above). If it should ever be necessary to make the contract a matter of record the affidavit of the witness could easily be taken, which would entitle the paper to be recorded in the office of the county clerk of the county.

As a matter of fact, a more simple agreement, similar to the following, would be perfectly legal:

\section{IthacA, N. Y., August 1, 1902.}

In consideration of one dollar to me paid, I, John Doe, agree to deliver one hundred bushels of potatoes to Charles Roe at his store at Ithaca, N. Y., on or before November 1, 1901; and I, Charles Roe, agree to pay John Doe, upon delivery of said potatoes, fifty dollars.

\section{(Signed) JoHN DoE.}

\section{Charles Roe.}

A contract may be made by correspondence, as, for example, one man may offer to sell to another or to do anything by letter. The sender of such a letter may recall it, verbally or by letter, at any time before its acceptance. The moment a letter of acceptance is mailed the contract or agreement is valid and binding, for the reason that the minds of the contracting parties have met. If, however, the acceptor adds any new matter or condition to his acceptance there is no meeting of minds until such time as the original writer shall 
have accepted such new matter or conditions. This has always been a fruitful field for litigation, and in accepting an offer by letter, or in any other way, great care should be taken not to add any new matter in the acceptance of any proposition. If new matter is, of necessity, added, it should always be remembered that the contract is not valid until such new matter is accepted expressly or implied by the original proposer.

Contracts may, of course, be made verbally, and anything which shows the actual meeting of minds, as for example, a word, a nod or a sign, or, in some instances silence even, as expressed by the old adage, "Silence gives consent," is sufficient; but this is so only when there is a duty to speak or when there is some act manifesting an acceptance of the proposal. But in ordinary business transactions it is always best to reduce the agreement to writing; in fact, it is often necessary to do this in order to make a valid agreement.

It is an established rule in most states that every contract for the sale of any goods, chattels or things for the price of fifty dollars, or more, is void unless, either

1. A note or memorandum of such contract be made in writing and be subscribed by the party to be charged thereby; or, 
2. Unless the buyer shall accept and receive part of such goods, or the evidences, or some of them, of such things in action; or,

3. Unless the buyer shall, at the time, pay some part of the purchase money.

It is also very generally provided that no action shall be brought whereby to charge the defendant upon any special promise to answer for the debt, default or miscarriage of another person, unless the agreement upon which such action shall be brought, or some memorandum or note thereof, shall be in writing, and signed by the person to be charged therewith, or some other person thereunto by him lawfully authorized.

This simply means that no man can be held lawfully for the debt of another, as, for example, the guaranty of an account of another, unless the guaranty or agreement is reduced to writing. Any agreement or contract, therefore, by which one person agrees to be responsible for another, must be in writing.

No contract or agreement is binding unless there is some consideration for it. This simply means that even after a person has agreed to do a thing, he cannot be made to do it, or pay damages for not doing it, unless he has either received something of value or has been promised something of value for the doing of the thing he agreed to do; except that when the person to whom the 
promise sought to be enforced was made has, because of the promise, done or undertaken to do something which he was not obliged to do, it would make no difference whether the person promising had received nothing for his promise. In other words, I cannot be held to my promise unless either I got something for it, or the other man gave up something on the strength of it.

The law of contract would fill many volumes, but we may, in the small space that we have, consider a great many of its important features sufficiently to guard us against some of the common errors. We shall first consider who may make binding contracts, and under this we shall find many different conditions, each requiring its own rule. On the question of how old a person must be in order to make a binding contract, the now generally accepted rule is that a minor, $i$. e., a person under twenty-one year's of age, cannot be held to any contracts, except his contracts for those things which are necessary to enable him to live according to his station in life and in reasonable comfort, health and safety. If he makes a contract for any one of these purposes he must pay for all that he receives under the contract, and pay for it at whatever its fair value is. However, he cannot be made to pay more than the fair value of what he has received, even though he has agreed to pay much more than the fair 
value. $\mathrm{H}_{\theta}$ is also at liberty to put an end to contracts of this kind at any time and not receive any more under them, but he must pay the fair value of what he has actually received. Of course, he may, if he choose, waive the defense of infancy and fulfil any of his contracts, except possibly those relating to real estate, which are sometimes held to be absolutely void, and, in case he does waive this defense, his contracts are as binding as any person's would be.

As to the requisite mental capacity of persons to enable them to make binding contracts, the following rules are generally adopted: When a person has been judicially declared insane, or incompetent, every person is charged with knowledge of his insanity, or incompetency. Consequently, any one who makes a contract with him does so at the risk of having the incompetent person refuse to perform it. The result is the same in cases where the insanity or incompetency has not been judicially declared, but the other party to the contract knew that the person was incapable of understanding the bargain. A contract made with a drunken person when he is so drunk as not to understand the nature of the agreement into which he has entered, stands on the same basis as those made with insane or incompetent persons.

As to the contracts of married women: It is 
now almost universally the rule that their contracts stand on the same basis as those of men or unmarried women.

It very often happens that after parties have made a contract they differ as to what they meant to agree to, and sometimes even allege that they have been deceived in the course of their negotiations. The law considers cases of this kind under the following heads:-Mistake, Fraud, Duress and Undue Influence. We shall treat them in that order.

Mistake.-There are so many different kinds of mistakes of intention, etc., that it will be impossible to deal with them here more than to say that in a majority of instances a person must stand by his contract if the mistake was entirely one of his own making, and was not induced by the other party. In other cases he may very generally be excused from the performance of the contract; but the only safe way to do is to explain the whole matter to your lawyer and trust him to find some way of correcting the error.

Fraud consists of representations known to be false, or made with reckless disregard as to their truth or falsity. They must be made with the intention that the deceived party shall act upon them, and he must act upon them to his damage. In such cases fraud will excuse the 
performance of a contract unless the one deceived choose to waive the fraud and go on with the contract, and one receiving any part of the benefits of the contract, knowing that he has been fraudulently induced to enter into it, thereby waives the fraud and will be bound by the contract.

Duress generally consists of threats of bodily harm or imprisonment so strong and imminent as to overpower the free will of the person entering into the contract; and it usually vitiates the contract and allows one upon whom the duress has been practiced to avoid the contract or successfully resist its enforcement.

Undue influence is that improper influence or persuasion whereby the will of a person is overpowered and his consent to entering into a contract is really not his own consent, but the doing of the will of another. Such influence gives him a right to avoid the contract if he choose.

We now come to the purposes for which contracts may be made. The general rule is that a contract may be made for any legal purpose, but that illegality of object voids a contract. This is the legal way of saying that one may not contract to do or procure the doing of an illegal act, and by an illegal act we mean an act which is expressly declared by statute to be illegal, or which was illegal by the express rules of the common law, or which is contrary to public 
policy, because it is manifestly injurious to the public at large. Probably the most common form of illegal contract is the wagering, or betting, contract. This is not now enforcible, though it was at one time. Indeed, it is now very frequently the rule that the loser is liable to pay to the overseer of the poor, or some similar person, three times the amount of the wager for the benefit of the poor.

As a general rule, it is best to reduce every contract or agreement to writing. As has been said, great formality, especially in small transactions, is not necessary. It may be written upon a scrap of paper, or better yet, upon the leaf of an ordinary memorandum book, being sure to obtain the signature of the contracting parties, with the signature of a witness whenever possible, and an expression of just what each party is to do.

In making a contract, one has to be very careful of the language employed, and must be very particular to know exactly what is meant by the various terms used. Of course, our "common law," as we call it, is simply a matter of usages and customs which have become so general as to be considered the law of the land. We find that in many instances certain words, terms and expressions have been given a particular meaning by custom, and it is a rule of law that any 
general usage or custom will govern the terms of a contract; hence, if a person buys a "cord" of wood where the custom and usage determines that a cord is 128 cubic feet, he will get that kind of a cord; but if, on the other hand, it is a general custom in that part of the country to consider a cord as being a pile 8 feet by 4 feet by 1 foot, he will simply get his 32 cubic feet for a cord, regardless of what he understood the word "cord" to mean. This is used only by way of illustration, but there are a great many expressions that require to be carefully explained in a contract, in order that there may be no misunderstanding.

Of course, a contract may be allowed to run so long that it will become, as we commonly call it, "outlawed"; that simply means that when a contract, which is not under seal, has been allowed to remain wholly unperformed for six years (or in some states for a shorter period) after performance was due, and there has been no written acknowledgment of the contract during that time, any action to enforce performance or recover damages is barred by the statute - of limitations. This same rule applies to all classes of actions and rights of action, and they are all sooner or later barred by the lapse of the prescribed period of time. This period varies from a few months in some statutory pro- 
ceedings to twenty years or upwards, which is the usual period of limitation of actions upon sealed instruments, or for the recovery of real property. This whole matter of the limitation of actions should be carefully borne in mind, and the local statutes consulted when there is any possibility of a claim outlawing, as it is always possible to prevent such an unfortunate occurrence by beginning an action at any time before the limitation is complete, even though it be but a day before the statutory period has elapsed.

Signing contract as agent, may impose liability on a note. Elsewhere in this work the advice is given not to sign a note to $\mathrm{or}^{\circ}$ for a stranger or one not deserving perfect confidence. It may be added that the fraudulent person does not usually work openly and ask his victim for his note directly. Instead, he approaches him with offers of a lucrative agency of some kind, or makes him a glittering proposition of some similar nature. His signature is asked to one of their "agreements" or "contracts," which "they always require," etc. Hidden in a mass of words, or perhaps a statement of terms in the contract, will be those terms necessary to make a negotiable promissory note. The note, when negotiated to a holder in due course, becomes effective against the maker, and all or many 
of the defenses which would be valid against the payee himself are destroyed. Generally speaking, if the paper signed contain an unconditional promise to pay a certain sum of money to another or to his order, or to the bearer, it will bind as a promissory note and be negotiable as such. And it makes no difference that it contains a recital of the transaction for which given, or that it is signed with the additional word "agent."

Another very common method of fraudulently procuring the execution of a negotiable note is to produce to the prospective agent a memorandum which is represented to him to be simply an acceptance of the agency about to be conferred upon him; this he signs, and after a short time it may come back to him in the form of a promissory note, the fraudulent party having cut off one end of the memorandum, leaving it-owing to its peculiar arrangement-a perfectly valid promissory note. These frauds were formerly much more frequent than now, but are still attempted in many parts of the country.

II. WARRANTIES UPON SALE OF HORSES OR OTHER ANIMALS

Upon the sale of a horse or other animal (particularly the former), various questions very frequently arise as to the right of an aggrieved 
party to obtain legal relief. It may be taken as a general proposition that when there is a sale, or contract for the sale, of a horse or other animal, which each can examine and judge of for himself, each party must look out for himself, and if it does not prove to be as desirable as the buyer expected, he has no remedy; that is, in the absence of further agreement or specification. It may be added that upon the sale of an animal, and especially of a horse, mere statements of opinion as to the quality of it, or puffing or extravagant expressions in the nature of opinion, not purporting to be statements of actual facts, have no effect. That is, such statements as, "he will beat anything in this village," or, "he is worth two hundred dollars any time," or, "he is first-class," are of no effect, as they are mere puffs and opinion. But a statement "he is perfectly sound," or, "he has a registered record of $2: 30$," is binding and becomes a term of the contract. If, however, the statement of warranty is a general one, as that the animal is perfectly sound, this statement means except those blemishes which are perfectly patent and visible to both parties, and it warrants against defects in the animal other than these only. But it becomes a term in the contract as to any other defects, and if there are any such, the buyer has his appropriate remedy. So, if a buyer contract to 
buy a horse which it is agreed shall be suitable for a specific purpose, he need not take it unless it proves, upon delivery, to be suitable for that purpose. In case any agreement or statement made by the seller is of such a nature as to amount to a term of the contract as explained above, a breach thereof will confer a right to relief upon the buyer. If the statement made can be said, by a court, to be important enough to go to the very root of the contract, so that if it proves false it destroys the very essence thereof, such untrue statement gives a right to the buyer to reject the animal and sue for damages for breach of contract. But if he accept the animal, and its defects are known to him at the time, or could have been ascertained by reasonable inspection, he has no right to damages; but if the term or representation which has been broken or proved false is not of such a nature as to be the very essence of the contract of sale and only partially affects it, so that it can be compensated in damages, it confer's no right upon the buyer to reject or return the animal, but he must accept and retain it, and sue for his damages against the seller. This often results in one recovering an uncollectable judgment against a worthless "horse jockey," as habitual horse traders are commonly called in the eastern states. 


\section{CHAPTER XIV}

MUTUAL LIABILITIES OF EMPLOYER AND EMPLOYEE, BUYER AND SELLER

1. LIABILITY OF FMPLOYER FOR AC'S OF EMPLOYEES

Ir is a general rule of law that a master is liable in damages for the acts of his servant. The principal exception to the rule is when the act of the servant is without the master's authority, either expressly conferred or implied from the nature of the employment and the character of his duties.

This rule of law is largely based upon the principle that it is the duty of the employer or master to employ competent and trusty servants to accomplish the work he has in hand, and that one who acts through another acts himself.

The master, however, is not generally liable for the malicious or willful act of the servant outside the scope of his employment, done without his direction or assent, though while in his employment. An act of negligence committed by a servant in consequence of his intoxication renders the master liable in damages, if he can reasonably be charged with knowledge of the servant's pro- 
pensity in that direction. So, too, any act performed by a third party, under the direction of the servant, renders the master liable, if the authority of the servant, either expressly or from the nature of the task, required or allowed the securing of an assistant.

Thus, when the master directed his servant to remove snow from a roof without instructions how to do it, and the servant of his own accord got a man to help him, it was held that the master was liable for injury to a passer-by from the snow thrown off by either of the men.

The books are filled with cases of liability of the master for acts of his servant. In fact, it is one of the most fruitful sources of expensive litigation. No rule can be laid down to fit every case, but if it is remembered that generally in the scope of his employment the law knows no difference between the acts of employer and employee much of such litigation will be eliminated.

In this connection it will be well to note that a master is not generally liable for injuries caused to a servant by another servant, though if the master has himself been negligent in performing his own duties he will be liable.

A master must furnish his servants a reasonably safe place to work in; reasonably safe and suitable machinery and appliances; a reasonable number of reasonably competent fellow-servants; 
and reasonably safe and sufficient rules, instructions and regulations for the guidance of the servants. If he does this he will not be liable for any injuries which may come to a servant from negligence, for the negligence will be that of the injured party or of one of his fellow-servants, because the master has done all that is required of him. This matter is now regulated by statute in New York.

\section{MECHANICS' LIENS}

A "lien" is a hold or claim which one person has upon the property of another as security for some debt or charge. Under our law there are several kinds of liens, but probably the most important is the class known as mechanics' liens. These are of great importance to carpenters, builders, masons, plumbers, painters and the like, and the provisions relating to securing them are so simple, and the liens so beneficial, that every man should be in a position to take advantage of them if he deem the payment for his services in any case doubtful or insecure.

The statutes in most states provide that any contractor, sub-contractor, laborer or material man who performs labor or furnishes material for the improvement of real property with the consent, or at the request of the owner or his agent, or of the contractor or sub-contractor, 
shall have a lien for the principal and interest of the value or the agreed price of such labor or materials, upon the property improved and the improvements, from the time that notice of lien is filed.

This lien will extend to and hold the owner's right or interest in the property and improvements existing at the time of filing the notice of lien. The lien will follow the property if it is removed, sold or transferred at any time after the notice is filed, and the owner's interest as it was at the time of the filing stands as security for the payment, notwithstanding the sale or removal of the property. But, if the labor or materials were furnished to a contractor or subcontractor, instead of directly to the owner, then the lien will not be for a sum greater than that earned by the principal contractor but unpaid to him on the contract at the time the notice was filed. But payments made by the owner before they are due under the contract, so as to defeat a mechanics' lien, will be of no effect as against a lien filed before the payments actually become due under the contract.

In order to secure such a lien as is above described, the person claiming it should file a notice of lien at some time during the progress of the work, or the furnishing of the materials, or within a limited period (frequently ninety 
days) after the completion of the contract, or the last item of work, or the furnishing of the last item of materials. It must generally be filed within the prescribed time, in the clerk's office of the county where the property is situated. After filing this notice, the lienor serves a copy upon the owner.

The lien will not generally be valid for more than one year after the notice is filed, unless within that time an action is filed in the county clerk's office, or unless an order be granted by the court, within that time, contimuing such lien, and the lien must then be re-docketed. Such an order is easily obtained, and although no order can continue a lien for more than one year, successive orders may be obtained. It is, therefore, necessary that a lienor shall see to it that his lien does not expire.

Any of the steps to be taken in the filing and selvice of the notice of lien, should be upon advice of counsel only; therefore, we will not here pursue the subject further.

\section{ARTISANS' LIENS}

A person who makes, alters, repairs or enhances the value of a chattel at the instance or with the consent of the owner, has a lien upon the same for his reasonable charges for service 
and materials while he remains lawfully in possession of it, and he may keep it until his charges are paid.

IV. LIENS OF HOTEL, BOARDING-HOUSE, LODGING-HOUSE AND LIVERY KEEPERS

Each of these classes of persons has a lien while in possession of, and may detain, the baggage and other property brought upon their premises by a guest, boarder or lodger, for proper charges due for his accommodation as such. But not every person who occasionally entertains a guest, or who has a claim against a boarder or lodger is entitled to such a lien, and to detain property, unless so entitled, may make the claimant liable in damages. To have a lien, one must be in the business of a boarding- or lodging-house keeper, and merely to have taken a single guest or lodger, or to have done so occasionally, will not suffice.

A livery- or boarding-stable keeper, or one pasturing an animal, has a lien upon the animal kept, boarded or pastured, for the compensation due for the same, so long as the claimant retains possession of it, and he may detain the animal, as well as any wagons, vehicles or harness of the owner which he is keeping in connection with the animal, until he is paid. 


\section{CHAPTER XV}

NOTES, DUE-BILLS, CHATTEL MORTGAGES AND BILLS $O F$ SALE

\section{PROMISSORY NOTES}

Among the more important of a great variety of written agreements or contracts are promissory notes. A promissory note is a written instrument, signed by the maker, containing an unconditional promise to pay a certain sum in money to another, on demand or at a fixed or determinable future time.

The same rules which apply to contracts in general are applicable to promissory notes. There must be a consideration, that is, there must have been something of value given for the note, as money, goods, services or the like, and the contract must have been devoid of all fraud in its inception to make the note a good and valid obligation. As to all negotiable paper, there are different rules of law which must always be remembered. When a promissory note is made payable "to order of" or "to bearer," or when a check or draft is drawn to order or bearer, it then becomes a "negotiable instru- 
ment," and many rules apply to it which apply to no other class of instruments. From this point on we will consider this class of commercial paper only, unless special reference is made to non-negotiable paper.

A note complete and regular on its face is not subject to the equities if transferred to an innocent third party before maturity for value, he having no notice of defects in the course of the instrument, provided, however, that, if it is payable on demand, it must have been presented for payment, within a reasonable length of time. This practically means that such a person holding such an instrument has a claim against which there are almost no defenses. It is also true that when there has been one person holding the note under the circumstances above described, then all persons who take it afterwards have all the rights against the maker and endorser's that he had unless those who take it afterwards have been guilty of fraud in procuring the making of the note, or in procuring its endorsement by those whom they seek to hold liable.

However, if it is shown that the note was transferred for the first time after maturity, the law presumes that the fact that it is due and has not been paid is notice to the purchaser that something may be wrong with the 
note, otherwise it would have been paid. In other words, no person who purchases a pastdue note from the payee himself is protected against original want of consideration, against fraud in its making or sometimes against any counter-claim that may be made by the maker of the note. If, however, a third party innocently and without knowledge of any of the equities or lack of consideration, fraud, etc., purchases a negotiable note before it is due, then the law protects the purchaser. For instance, if A, a lightning-rod man, sells to $B$ and takes his note, and afterwards $\mathrm{C}$ purchases the note for value before maturity without knowledge of fraud on B by A, C is protected and can collect the note even though fraud and misrepresentation were practiced by $A$ on $B$. This must lead to the conclusion that it is unsafe to give a note unless the maker is entirely satisfied that all of the conditions leading up to the making have been fully complied with, because it is quite sure to turn up later in the hands of an innocent third party.

The date of a note is of great importance. It is not counted in the time of a note, thus: A note given July 1 for thirty days is due July 31. In some states three days of grace are given in addition, but in New York, as in some other states, days of grace have been abolished. 
A note payable to the order of another must be endorsed by that other to render it transferable. There are several forms of endorsement. The payee, that is, the person to whom the note is made payable, may simply write his name on the back. In such a case he becomes liable for the note, provided it is duly presented for payment at the bank or place of payment named in the note, or at the place of business or residence of the maker, and, if it is not paid, it is duly protested by a notary public or other proper person. Sometimes a note given by $\mathrm{A}$ to $\mathrm{B}$ may be endorsed as follows: "Pay to the order of $\mathrm{C}^{\prime \prime}$; in which case $\mathrm{C}$, to make it negotiable, would have to endorse it. In this way a note frequently has several endorsers. The rule of law is that endorsers are severally and collectively liable on a defaulted and protested note and that each has recourse over and against the previous endorser and the maker. The first endorser has, of course, recourse against the original maker. If an endorser desires to protect himself against loss and merely endorses to make the note negotiable, he may escape such liability by so stating on the back of the note before his signature. The words "without recourse" above the signature are commonly accepted in the business world as a proper protection when an endorser desires so to escape liability. 
Because of the difficulty sometimes encountered in rural districts in properly protesting an endorsed note, it seems advisable, except when a note is made payable at a bank, not to take a note with an endorser unless the endorser is willing to add before his name words similar to the following: "For value received, I hereby waive notice of protest of the within note."

Before taking or purchasing a note examine it carefully in the following particulars: Is it properly dated? Does it name the exact amount of money to be paid? Does it say pay to "bearer" or to "order" ? In either case it is negotiable, but if payable to "John Doe" only, it is non-negotiable. Does it name a place of payment? Does it state that it is made for value received? Does it state "with interest"? Otherwise it would draw no interest until due. Sometimes notes are made payable on demand, and if such a note does not contain the words "with interest," then interest is payable only after demand is made.

A form for a negotiable note follows: $\$ 500$. IthacA, N. Y., July 1, 1901.

Three months after date, for value received, I promise to pay to the order of John Doe (or to bearer) the sum of Five Hundred Dollars . . . . . . (\$500) at the First National Bank of Ithaca, N. Y., with interest.

(Signed) Richard RoE. 
In such a note the essential things are the date, the amount, length of time, the signature, the admission that it is given for value received, and whether payable to "bearer" or to the "order" of some one. The things desirable, but not necessary, to its validity, are place of payment and whether with interest. Where the words "with interest" are used the law presumes it to be the legal rate in the state in which the contract is made; and if a lesser rate is contemplated it should be so stated, as, for example, "with interest at four per cent."

By far the safest kind of note for the ordinary business man, removed from a banking center, to take is the "joint and several" note, where, instead of becoming an endorser, the third person obligated becomes a party to the note.

There is practically no difference as to liability, whichever phraseology in the following form of note is adopted:

$\$ 500$.

ItHACA, N. Y., July 1, 1901.

One vear after date, for value received, I (or we, or either of us) promise to pay to Joln Doe, or order, the sum of Five Hundred Dollars . . . . . . . . (\$500) with interest.

(Signed) Richard RoE. JAMES SMITH.

In other words, whether the note says, "I promise to pay," or, "We or either of us promise 
to pay," the note is a joint and several obligation, equally binding on both Richard Roe and James Smith.

With such a note no protest is necessary to hold both signers, although after notice to the holder of the note, from James Smith, to proceed to collect said note, if the owner fail to use due diligence to collect and Richard Roe in the meantime become insolvent, James Smith will undoubtedly escape payment of the note.

Sometimes the word "principal" is added to the name of the person giving the note and the word "surety" to the name of the "signer." The addition of these words does not affect the rights of the holder or owner in the least, but they do define the relations existing between the principal and the surety, and render it unnecessary for the surety to make special proof in case he pay the note, and then proceed by suit or otherwise to recover from the principal.

It frequently happens in the transfer of notes that the seller is required to guarantee the note. There is no prescribed form for such a guaranty. The usual form, however, is substantially as follows:

"For value received, I guarantee the payment when due (or the collection) of the within note."

A guaranty of payment, when due, is the 
safer form, because the guarantor becomes immediately liable upon default, whereas, if he guarantees collection only, the owner must exhaust every other legal remedy before he can proceed against the guarantor. In other words, he must bring an action and proceed by execution after judgment to try to collect.

A large part of the commercial business of the world is done by negotiable bills and notes. In fact, some of our national eurrency is but a higher type of secured note, having behind it not only the credit of the government, but actual coin as collateral. We often hear the expression that the government can make money by simply printing its notes. So, in a sense, can the reader, but the notes will be worthless if issued beyond the limit of assets and actual resources. For example, A may give his note for $\$ 100$. He may, in fact, give a second or a third; but the time is sure to come when the limit is reached, and if $A$ has gone beyond his actual assets in the giving of notes, then the merest hint or bit of gossip, the slightest calamity or loss may pull down the whole structure of inflated credit upon his head. We regard a treasury note as good. It is only absolutely so when there is $x$ like amount of gold or silver behind it in the treasury. We should not endanger ourselves by advocating that the collateral which backs our 
currency should be one cent less than the amount called for by the currency. Such collateral may be gold, silver or anything of value; but there should be value equal to one hundred cents for every dollar of currency, even though the silver dollar becomes a thousand times larger than the gold dollar, or vice versa.

This leads us to the consideration of semring private notes. As we have seen, such notes may be and are largely secured by endorsement, by sureties and by guaranty. They are also largely protected by collateral. In the case of the private individual, the field of collateral is as large as in the commercial world and is of almost endless variety. Notes are often protected by mortgages on real estate, by chattel mortgages, by the deposit of bonds or other notes, by warehouse receipts, or by the delivery of personal property of any kind. A note having collateral securing its payment carries with it into the hands of the purchaser full recourse to such collateral by the mere change of ownership of the note.

In some states there are special statutes regulating, to some extent, the form and subject matter of notes; but it is only necessary to refer to this fact here, the general principle of the law of negotiable paper being the same everywhere. Negotiable notes, in general, by reason of the 
fact that they enter so largely into the every-day business life of the world, have been often used in fraudulent and swindling schemes out of which has grown much litigation. Because of patent-right swindling, New York and several other states have passed laws making it necessary for a note given for a patent-right to bear the words "Given for a patent-right" across its face. It would be impossible to enumerate the many schemes of swindlers to get possession of a promissory note which would be valid in the hands of an innocent third party.

The best possible advice that can be given to a person who contemplates giving a note to a stranger for anything, or for any purpose whatever, is "Don't."

As to all promissory notes, even when given to friends and business acquaintances for legitimate purposes, unless you have ample resources to meet them it is well to consider most deliberately before signing, because notes have the bad habit of coming due just when money seems scarcest. However, when notes are based upon assets or upon trustworthy and real expectations, they are of the greatest benefit in the commercial world, for it must be remembered that fully ninety per cent of the business of this country is done on credit, in which negotiable paper plays by far the largest part. 
II. DUE-BILLS, ORDERS, RECEIPTS

A due-bill differs somewhat from a note in that it is a simple acknowledgment of debt. It may be payable in money, services, produce or merchandise. It is perhaps the simplest form of commercial paper, for example:

$\$ 30$.

IтнaCA, N. Y., July 1, 1901.

Due John Doe, or order, Thirty Dollars (or thirty bushels of wheat).

(Signed) RichaRd RoE.

An order is a request for one person to surrender an amount of money or merchandise and charge to the account of the signer, as:

JoHN DoE:-

IтHACA, N. Y., June 1, 1901.

Please pay to James Smith, on demand, the sum of Twenty Dollars (or ten bushels of wheat), and charge to my account.

(Signed) RichaRd RoE.

In all business transactions receipts are generally asked for and given. It must be remembered, however, that the ordinary receipt is not conclusive of payment. It is, at best, only prima facie evidence of payment and can always be disputed and modified by the allegation that it was given under misapprehension, etc. If it is desirable to close a matter up for all time and to make a really binding receipt for moneys paid, it should take something like the following form: 
IthaCA, N. Y., December 30, 1901.

Received of John Doe the sum of one hundred dollars $(\$ 100)$, in full of all accounts to date, and in consideration of the said sum and the premises, I hereby release the said John Doe from all claim of every name and nature whatsoever, to the date hereof.

Witness my hand and seal.

RichaRd RoE (L. S.).

It will be seen that we here include the consideration imported by the seal as well as the money consideration. This makes a radical difference in some states.

\section{CHATTEL MORTGAGES}

A chattel mortgage is a transfer of personal property as security for a debt. There need not generally be an actual change of possession of the property in order to make the chattel mortgage valid, but a formal agreement that the property is transferred is enough. However, if there is to be no actual and continuous change of possession of the property it is almost always required that the chattel mortgage be filed in a town clerk's office, or a county clerk's office, in the town where the mortgagor resides, in order to make it valid against third parties who are creditors of the mortgagor, or who have subsequently, and in good faith, purchased or acquired liens apon the mortgaged property. It is also 
generally required that the mortgagee, i. e., the person to whom the mortgage is given, shall, shortly before the expiration of each period of one year after the filing of the chattel mortgage, file a statement in the same office, giving certain information about the transaction and showing the amount due on the mortgage. The penalty for failing to comply with this requirement is the same as for failing to file the mortgage originally. A chattel mortgage is generally good as against the mortgagor and all other persons, except creditors and subsequent purchasers or incumbrancers of the property in good faith, regardless of any filing or refiling whatever. The following is a short form of chattel mortgage:

Know All Men By These Presents, that I, John Brown, of Ithaca, N. Y., hereby sell and assign to John Jones, of the same place, one democrat wagon, we lumber wagon, one set of single harness and one set of double harness, all of which are now in $\mathrm{my}$ barn at Ithaca, aforesaid. This grant is intended as security for the payment of Thirty Dollars $(\$ 30)$, with interest, on or before the expiration of three months from the date hereof, which payment, if duly made, will render this conveyance void.

In Witness Whereof, I have hereunto set my hand and seal this.... day of ...., 190... 
It is better to have the execution of this chattel mortgage acknowledged before a notary public, or justice of the peace, if possible, or at least to have a witness to the signature.

\section{BILIS OF SALE}

A bill of sale is a written agreement whereby the title of personal property is transferred. It is one of the most common agreements. The following form will be found sufficient for most cases:

I, John Brown, of Ithaca, N. Y., in consideration of One Hundred Dollars ( $\$ 100)$ paid to me by John Jones, of Owego, N. Y., do hereby bargain and sell to the said John Jones the following described property. (Here describe the property transferred.)

WitNess my hand and seal this..... . day of . . . . . , 190 . .

It is also better to have the execution of this bill of sale acknowledged before a notary public, or justice of the peace, if possible, or if not, to have a witness to the signature. 


\section{CHAPTER XVI}

GIFTS, WILLS, ADVANCES, USURY AND TAXES

\section{GIFTS}

GIFTs, especially between members of the same family, being of frequent occurrence, and the validity thereof often coming into question, the rules relating to them should be rather fully considered.

A gift is the voluntary transfer of property to another without anything being done or given in return-in other words, no consideration is necessary; if there is consideration, then it is a contract and enforceable as such. But as the law refuses to enforce promises unless given in return for a consideration, a promise to give something-that is, to make a gift-is of no effect, and will not be enforced. In order to be of any effect in law, the gift must be completed and fully executed as explained below. If this is done, the law will then recognize the gift and sustain the transfer of the property. If the gift is once made and the transfer of the property completed, the change of ownership is 
then perfect and cannot be revoked, except in the case of gifts made in expectation of death, as will be explained later.

Gifts of real property are simple, and must of course be by means of a deed. The rules given in the article on deeds (Chapter IX) fully apply in this connection, the law as to gifts here given applying to personalty only.

A gift may be made between two living persons not upon expectation of death; or it may be one made by the giver while in danger or fear of death and in contemplation of the same.

To make valid the ordinary gift, not made in contemplation of death, there must be an intention to give, and proof of the same, and actual delivery of the property over to the donee or some one for him. Delivery is the chief essential, and unless there is such a delivery of the property that, according to its nature, it transfers and gives over to the receiver full dominion and control thereof, it is incomplete as a gift and legally ineffective. Merely to say, for instance, "I give you this horse," or, "I give a hundred dollars of my account with _ Savings Bank" is of no effect unless accompanied by the proper delivery of the thing given over to the donee; in the case of the horse, the animal itself, and in the case of the money in the bank, by delivery of the proper evidences or 
paper, as hereinafter explained. Some cumbersome articles, incapable perhaps of immediate manual delivery, may be delivered by giving over to the donee as full possession and control of them as is possible: as in the gift of a stack of hay, or a corn crop as it stands, ete. If the donee is already in full possession, no further delivery is necessary. Generally speaking, a gift of a note, check or stock certificate properly endorsed, transfers title to what it represents and all rights thereunder, but delivery of the paper is generally essential.

To make a gift of a savings bank deposit, it is best to withdraw the same and make a deposit in the name of the donee; or have the bank transfer the account to the name of the donee; but it may be done by delivery of the book with or without check or written assignment.

A gift made in contemplation of the death of the giver is called donatio causa mortis; these gifts are only made in the immediate apprehension of death, and are subject to the implied conditions that if the giver should not die of that sickness, or if the donee should die first, or if the giver should revoke the gift before death, then the gift would be void. This form of a gift is very frequently adopted when a person desires to dispose of his property during his lifetime and not trust it to administration after his 
death. It will be seen that the giver does not divest himself of his property so that in case of recovery it would not belong to him, the gift becoming effective only upon his death as expected.

Gifts of property made by a debtor to escape the payment of debts are generally held void and may be set aside by his creditors; such gifts, however, bind the giver, and he cannot compel a return of the property on the ground that he had a fraudulent intent in disposing of it. This whole matter, however, is so involved that a further statement of its rules would be of no assistance.

\section{I1. WILLS}

A will may dispose of either real or personal property, or both. In New York, and most other states, only persons who are over twenty-one years of age may will real property, while sixteen and eighteen years are the common ages at which oue may will personal property. Generally an idiot, or a lunatic, or a person laboring under mental disability, which prevents his understanding his act and circumstances, may not make a valid will. In most states a person leaving a husband or wife or near relatives, may not give more than one-half of his estate to a charity.

A will is by far the most important legal 
document one is ever called upon to sign, yet less care is commonly taken in drawing and exeeuting a last will and testament than in the execution of the ordinary deed, mortgage or contract. This is especially true in the country, where, very often, wills are made which jeopardize the property for which a man has spent a lifetime of labor. Of all documents, except as to the formalities of execution, that is, the signing by the testator or maker and the witnesses, wills may be the most simple and informal. Any paper in writing which shows the clear intent of the testator is sufficient even though it contains but few words. Whenever possible, have an attorney draw the will, and attempt to do so yourself only when there is no way of securing legal assistance.

While the law is very liberal as to the contents of a will, nevertheless it is very strict as to the manner of executing it, by which we mean the signing, witnessing, etc. A will executed in accordance with the following directions will be found valid in New York and, also in most other parts of the United States, except in Louisiana, where the rules are too complicated for a work of this size and character.

The testator, that is, the one whose will is being made, must in some way know the contents of the wili; then he must ask the wit- 
nesses to witness his will; then the testator must sign it, either by name or by mark, at the end of the will and affix his seal, signature or mark in the presence of the three witnesses. The witnesses' statement and signatures may follow the testator's signature, but it will almost invariably avoid the will if anything else follow his signature; then let him declare it to be his last will and testament, and ask the three witnesses to sign, which the witnesses will do in his presence and in the presence of each other, and add their places of residence after their signatures. Immediately following the testator's signature, and above the signatures of the witnesses, should be a statement showing that all of these formalities were observed. Such a statement is given in the following form and may be written into the will at the point indicated. This will serve in years after to remind the witnesses of what was done, as they will see that they signed the statement at the time, though they may have forgotten, until they read it, that all of these things actually occurred. Of course, these particulars may be varied sometimes and not affect the validity of the will, as, for example: only two witnesses are required in some states; the seal after the testator's name may be omitted in some states; and nowhere need be more thar the word "seal" and not a real 
seal. The testator may, in some states, either subscribe the will in the presence of the witnesses, or acknowledge to them that he has subscribed it, showing the signature and the will, and may even do this to each one separately; but if he does this he must declare the will to each of them. A testator may also sometimes ask another to write his name for him, and if the latter does so in his presence and signs his own name as a witness to the will, with a statement of the testator's request to him, and of the fact that he did sign for the testator, the signature will generally be good; but it is always better to have the testator at least make his mark. As a final caution, let me say that it will be found far safer and better in the vast majority of cases to take no chances upon the probabilities of safety in omitting any of these details. Of course, any credible competent person may be a witness, except that any one who talies anything under the will is not competent as a witness.

The following may be adopted as a brief and simple form of will with a proper attestation clause:

I, John Doe, of the city of Ithaca, N. Y., do hereby declare this to be my last will and testament.

First, I direct the payment of my just debts, if any. Second, I give, devise and bequeath to . 
(Here insert just what is desired to be given. If land, a brief description will be sufficient, as "My homestead farm," ete.)

Third, I give, devise and bequeath . (and so on with each separate bequest).

Likewise, I make, constitute and appoint Richard Roe to be executor of this my last will and testament, hereby revoking all former wills by me made.

Witness my hand and seal this...... day of , 190 .

(Signed) John Doe. (Seal).

[The attestation clause, or statement for the witnesses to sign is as follows and should be at this point in the will:]

Subscribed by the testator in our presence (or if only acknowledged to the witnesses, say: Acknowledged by the testator to each of us to have been subseribed by him, and continue in either case as follows): and, at the same time, declared by him to us to be his last will and testament, and, thereupon, we at his request, and in his presence (and if all of the witnesses are present at the same time, add: and in the presence of each other; and continue as follows): sign our names hereunto as witnesses, this . . . . day of . . . . . , 190 . . , and add our places of residence.

Whenever a will disposes of real property it should, after due probate in the Surrogate's Court, be recorded in the office of the county 
clerk, as it may become an important link in a chain of title.

\section{ADVANCING MONEY OR PROPERTY TO ONE'S} CHILDREN

It not infrequently happens that parents desire to assist their children when they leave home and begin business on their own account. When the parents have a competency, no wiser disposition can be made of a portion of the estate than to loan it to their natural heirs, provided, however, that not enough is so loaned as to seriously endanger the income necessary for the support of the parents. An agreement somewhat as follows should be entered into, that justice may be done to all the children:

WherEas my father (or, mother or, parents) is (or, are) about to loan to me five hundred dollars (or if property describe it and state the value agreed upon), therefore I promise to pay five per cent interest annually on said amount if demanded by my father (or, party loaning the money); and I accept the same as an advancement from his estate, and release said estate from that amount. Otherwise, this loan is to be without interest until such demand is made; but in no case shall such demand for the payment of interest be retroactive, but interest shall be payable only from the time of a demand for the same. 
By this method of disposing of some of the property not needed at the time for the support of the parents, provision is made for an income in case of need or misfortune, the children are helped when they most need help, and, above all, the rights of the younger children are protected. Then, too, the pleasure of giving and receiving during the lifetime of parents and children should count for much.

\section{V. USURY}

Usury is the act of intentionally taking or reserving or contracting to take or reserve, for the use or loan of money, a greater compensation than the rate of interest allowed by law.

The rate of interest known as the "legal rate," and which is the limit permitted by law, varies in the different states, being six per cent in New York, Pennsylvania and New Jersey, and in some other states much higher. Only the general rules can be here stated, in this connection; they must be verified by reference to the statutes of the particular state in question. Generally, all bonds, bills, notes, etc., whereby there shall be reserved or taken, or agreed to be reserved or taken or secured, any greater sum or value for the loan or forbearance of money than the legal rate of interest, are either void 
or the interest thereon forfeited. By "void" is meant that it will be so held at the option of the debtor, and of him only. It is personal to him and his estate and none other can take advantage of the statute and have it declared void. As to every one else, it is fully valid and enforceable. In most states, a corporation cannot use the defense of usury as a shield and escapo liability upon its obligations on that ground.

Special rules, not to be considered here, apply to pawnbrokers and to certain loans where collateral security is furnished.

\section{TAXES}

Taxes which have been legally and properly assessed and levied upon real property become a lien thereon from the time the assessment is confirmed and finally corrected and completed. This lien will follow the property into the hands of any subsequent owner, whether or not he has had notice of the existence of the same. Property is, therefore, liable not only for all taxes assessed against it from the time one becomes owner, but is also subject to the lien of, and may be sold for, any taxes theretofore assessed against it and which are unpaid. It is therefore important, before purchasing, to make inquiry as to outstanding taxes of the proper officers. 
If, however, the purchaser has obtained a warranty deed from the seller, he may recover from him any taxes which he is compelled to pay and which were completely assessed, and a lien upon the property before he took it.

What may be taken for taxes is often a very important question. Of course, as indicated above, the land itself is liable for the taxes assessed against it, and may be sold for the same if they are returned as unpaid. But there is a more summary method of collection than that. It is generally provided that after the designated days during which taxes are receivable, the collector shall call at least once upon every resident taxed, at his residence, and demand payment. If any person neglect or refuse to pay his tax, the collector levies upon any personal property in the county owned by or in the possession of any person who onght to pay the tax, and may sell it at public auction; and the fact that a third party may claim it will not prevent such sale.

VI. REAL PROPERTY PURCHASED WITH PENSION MONEY EXEMPT FROM TAXATION

Property purchased with pension money is, in many states, assessed like other property; but on the review day the owner may present to 
the assessors an application showing that such real property was wholly or partially purchased with the proceeds of a pension granted for military or naval services, stating the amount of money so used and the assessed valuation of the property. Military rewards, pension money, and real property bought with pension money, cannot be taken for ordinary taxes. 


\section{CHAPTER XVII}

POWERS OF ATTORNEY, AFFIDAVITS, LEGAL TENDERS

\section{POWERS OF ATTORNEY}

A power of attorney is an instrument empowering one person to act for another. A power of attorney is a very simple instrument to draw, in ordinary cases; and as it is so often necessary to authorize another to do something in one's behalf, a suitable form is given herewith. It must be borne in mind that a power of attorney does not require the party authorized to perform the act on behalf of another to be an attorney in the true or legal sense of the word, but any competent person may act as another's agent, under a power of attorney. This form will be found sufficient in all ordinary cases:

Know All Men by These Presents: That I, . . ........ . , of Ithaca, New York, have nominated, constituted and appointed, and by these presents do nominate, constitute and appoint. . . . ........ . of the same place, my true and lawful attorney, for me and in my name, place and $\mathbf{P}$ 
stead to (here state the thing that it is desired to authorize the agent to do-as, for example, receive all payments upon account, or, have charge of property, or, whatever it may be), with full power of substitution and revocation; hereby ratifying and confirming all that my said attorney or his substitute may lawfully do in the premises.

WitNEss my hand and seal this 1st day of August, 1902.

In the presence of:

\section{AFFIDAVITS}

An affidavit is a statement reduced to writing and sworn or affirmed to before some competent authority. Great care should be taken in drawing affidavits that they contain all of the facts that they are intended to prove, as it very frequently happens that some very important fact is found omitted when it becomes necessary to use the affidavit. A very good way of securing a complete affidavit when the services of your lawyer are not available, is to write a formal heading, as given below, and let the person who is to make the affidavit write in all that he can remember about the matter in hand, after which talk the matter over carefully and see if anything has been omitted. If it has, add it to the matter already written and then write the formal 
ending and let the person sign the affidavit, after which have some competent authority sign it, as a notary public or justice of the peace, etc.

The following form is sufficient:

$\left.\begin{array}{l}\text { State of New YoRk } \\ \text { County of Tompkins } \\ \text { Town of Ithada }\end{array}\right\}$ SS:

John Brown, being duly sworn, deposes and says that he resides in the town of Ithaca aforesaid, and is forty seven years of age. Deponent further says (here insert all that he has to say about the matter in hand).

And further deponent saith not.

(Have deponent sign bere)

Subscribed and sworn to before me this..... day of . . . . , $190 \ldots$

(or Notary Public, as the case may be.)

\section{LEGAL TENDERS}

It must be borne in mind that one does not always have a right to pay his obligations in whatever money he may choose to offer. For example, it is provided by the laws of the United States that the silver coins, by which is meant the silver dollars, half dollars, quarter dollars and dimes, are legal tender up to an amount of five dollars only, and that the minor coins, which are the five-cent piece, three-cent piece and 
one-cent piece, are legal tender up to the amount of twenty-five cents only. Therefore, if any one choose to be technical, he may refuse to receive more than these amounts in such coins and thus prevent the discharge of an obligation.

Upon the question of the necessity of tendering exact change, we need only to note that a person who is under obligation to pay a certain sum must, as a usual thing, tender the exact amount, and cannot compel the creditor to make change. There have been some interesting cases upon tender of fare to street-car companies, it having been held in one of the western states that it is not unreasonable to ask a street-car conductor to take a five-cent fare out of a fivedollar gold-piece, while in New York it has been held that a rule established by a company that it will not make change from a bill larger in amount than two dollars, is a reasonable rule, and may be enforced by the company. The true rule is that a street-car company may be compelled to make change up to any reasonable amount; and the same rule undoubtedly applies to railroad companies. The government has adopted a rule that it will not make change for postage stamps unless it finds it convenient to do so, thereby retaining the privilege of refusing to make change at any time when its convenjence warrants the refusal. 


\section{PART III-INVENTORIES FROM THE CENSUS}

If one thing more than another has been emphasized in the preceding chapter's, it is the need of taking an inventory, in ordinary business, at least once a year. No firm or individual can afford to go on blindly, whether the business returus large or small profits. If the business is a losing one the sooner that fact is discovered, and the amount of the loss, the better it will be for all concerned. In starting a new business it frequently occurs that the first year's operations show no profits. Slight losses may be borne cheerfully if there is promise that the business will increase and profit will accrue in the future. But every careful business man wants to know just what the losses are or have been and, if possible, when, how or where they cccurred. Having secured the facts, the judgment is enlightened and then it can be intelligently determined whether to go on or to close the business before losses have absorbed all the capital stock.

"Uncle Sam," though much of a gentleman and the wealthiest personified individual on the 
globe, his children blessed with phenomenal profits, finds it necessary to take account of stock once every decade. There is some excuse for his taking an inventory only once in every ten years, since the expense of taking such inventory (census) and compiling and digesting the facts is great. Two years since Congress appropriated $\$ 13,516,210$ for doing this work. The compilation of the results had not proceeded far before "Uncle Sam" saw that he could well afford to clean and disinfect the streets of Havana, organize schools, reward General Gomez for long-continued, courageous work for the cause of liberty. He could do much for Porto Rico. He could spend millions in the Philippines with the hope and expectation of benefiting and ennobling six million people submerged for centuries in semi-barbarism and groaning under the incubus of despotism.

As the profits and wealth of the nation were revealed in the census footings, "Uncle Sam," after he had counted cash on hand, had noted the monthly receipts and computed assets, concluded. that he was justified in making a little permanent investment for his boys. Forty millions were given for an unfinished ditch; then, in order to complete the ditch that the stormy Atlantic might be married to the placid Pacific, it was decided to spend $\$ 144,233,358$ more. Two hun- 
dred millions, in round numbers, for a ditch appears like not a little investment, but a great one. However, as a per capita investment it is not larger than a farmer would make if he purchased an acre of average land.

All of these expenditures, past and present, are justified because needed, and because the government through monthly, yearly and decade statements is kept fully informed of the financial condition of the complicated and stupendous national transactions. In other words, "Uncle Sam" employs a vast army of bookkeepers, accountants, appraisers, detectives and experts, and could not administer the government's financial affairs without these persons.

Since many of the readers of this book will not have access to the census reports, especially to those which relate to agriculture, it is fitting that a brief summary of the government's inventory of rural wealth be placed in convenient form for ready reference. These figures are from the reports of the Twelfth Census (taken in 1900): 


\section{AGRICULTURAL POPULATION}

Number of males and females over ten years of age, June 1, 1900, engaged in specified agricultural pursuits, by states and teritories

\begin{tabular}{|c|c|c|c|c|c|c|}
\hline \multirow{2}{*}{$\begin{array}{c}\text { States and } \\
\text { territories } \\
\text { by } \\
\text { divisions }\end{array}$} & \multirow{2}{*}{$\begin{array}{l}\text { All agri- } \\
\text { cnltural } \\
\text { pursuits* }\end{array}$} & \multicolumn{3}{|c|}{ Agricultural Laborerst } & \multirow{2}{*}{$\begin{array}{l}\text { Dairymen } \\
\text { and dairy- } \\
\text { women }\end{array}$} & \multirow{2}{*}{$\begin{array}{c}\text { Farmers } \\
\text { and } \\
\text { planters }\end{array}$} \\
\hline & & Total & $\begin{array}{l}\text { Farm and } \\
\text { plantation }\end{array}$ & $\begin{array}{c}\text { Garden and } \\
\text { nursery }\end{array}$ & & \\
\hline U. S....... & $10,438,188$ & $4,459,346$ & $2,047,658$ & 45,375 & 10,931 & $5,488,873$ \\
\hline $\begin{array}{l}\text { Maine ..... } \\
\text { N. H. ..... } \\
\text { Vt......... } \\
\text { Mass. . . } \\
\text { R. I. ...... } \\
\text { Conn. . . } \\
\text { N. Y....... } \\
\text { N. J....... } \\
\text { Pa......... }\end{array}$ & $\begin{array}{r}76,923 \\
38,782 \\
49,820 \\
66,551 \\
10,957 \\
44,796 \\
375,990 \\
68,881 \\
341,712\end{array}$ & $\begin{array}{r}21,976 \\
12,714 \\
18,443 \\
31,515 \\
5,304 \\
19,847 \\
148,456 \\
33,220 \\
123,208\end{array}$ & $\begin{array}{r}12,093 \\
8,989 \\
12,583 \\
23,321 \\
3,984 \\
14,817 \\
96,833 \\
23,734 \\
65,479\end{array}$ & $\begin{array}{r}268 \\
94 \\
281 \\
3,726 \\
617 \\
1,345 \\
7,634 \\
2,434 \\
3,898\end{array}$ & $\begin{array}{r}17 \\
14 \\
15 \\
63 \\
6 \\
54 \\
451 \\
153 \\
454\end{array}$ & $\begin{array}{r}51,043 \\
23,955 \\
29,942 \\
29,778 \\
4,680 \\
22,231 \\
210,018 \\
31,196 \\
198,704\end{array}$ \\
\hline $\begin{array}{l}\text { Del........ } \\
\text { MId........ } \\
\text { D. of C.... } \\
\text { Va. ....... } \\
\text { W. Va..... } \\
\text { N. C....... } \\
\text { S. C....... } \\
\text { Ga. ....... } \\
\text { Fla........ }\end{array}$ & $\begin{array}{r}19,002 \\
95,554 \\
1,488 \\
300,268 \\
151,722 \\
459,306 \\
393,693 \\
522,848 \\
88,688\end{array}$ & $\begin{array}{r}9,126 \\
50,134 \\
618 \\
138,613 \\
58,796 \\
233,288 \\
237,326 \\
282,347 \\
37,343\end{array}$ & $\begin{array}{r}5,831 \\
33,786 \\
408 \\
71,949 \\
20,183 \\
84,701 \\
96,660 \\
120,931 \\
15,817\end{array}$ & $\begin{array}{r}94 \\
1,272 \\
177 \\
932 \\
203 \\
383 \\
223 \\
660 \\
240\end{array}$ & $\begin{array}{r}12 \\
400 \\
132 \\
131 \\
189 \\
84 \\
59 \\
237 \\
87\end{array}$ & $\begin{array}{r}9,385 \\
41,399 \\
211 \\
154,927 \\
87,737 \\
216,062 \\
149,594 \\
218,069 \\
37,486\end{array}$ \\
\hline 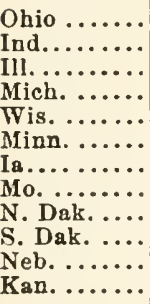 & $\begin{array}{r}414,662 \\
342,733 \\
462,781 \\
312,462 \\
270,007 \\
258,944 \\
371,604 \\
463,293 \\
71,626 \\
82,857 \\
186,587 \\
271,252\end{array}$ & $\begin{array}{r}138,066 \\
118,498 \\
184,959 \\
97,527 \\
93,718 \\
94,195 \\
133,450 \\
162,916 \\
24,193 \\
26,749 \\
59,601 \\
89,271\end{array}$ & $\begin{array}{r}68,835 \\
60,085 \\
102,396 \\
48,885 \\
37,658 \\
39,280 \\
64,789 \\
65,900 \\
14,898 \\
11,445 \\
26,727 \\
39,681\end{array}$ & $\begin{array}{r}2,438 \\
832 \\
2,233 \\
933 \\
861 \\
480 \\
657 \\
1,184 \\
38 \\
61 \\
310 \\
485\end{array}$ & $\begin{array}{r}792 \\
488 \\
587 \\
140 \\
131 \\
233 \\
269 \\
443 \\
18 \\
21 \\
111 \\
201\end{array}$ & $\begin{array}{r}260,539 \\
212,363 \\
258,713 \\
196,562 \\
164,414 \\
151,937 \\
224,721 \\
280,486 \\
43,749 \\
49,601 \\
116,344 \\
167,915\end{array}$ \\
\hline $\begin{array}{l}\text { Ky. ........ } \\
\text { Tenn. . . . } \\
\text { Ala........ } \\
\text { Miss. . . . }\end{array}$ & $\begin{array}{l}408,185 \\
413,406 \\
515,737 \\
490,582\end{array}$ & $\begin{array}{l}165,432 \\
182,905 \\
286,195 \\
259,668\end{array}$ & $\begin{array}{l}69,460 \\
69,430 \\
98,094 \\
84,019\end{array}$ & $\begin{array}{l}644 \\
822 \\
630 \\
271\end{array}$ & $\begin{array}{r}294 \\
269 \\
148 \\
79\end{array}$ & $\begin{array}{l}230,206 \\
218,896 \\
215,354 \\
220,090\end{array}$ \\
\hline
\end{tabular}


I. Agricultural Population - Concluded.

\begin{tabular}{|c|c|c|c|c|c|c|}
\hline \multirow{2}{*}{$\begin{array}{c}\text { States and } \\
\text { territurios } \\
\text { by } \\
\text { divisions }\end{array}$} & \multirow{2}{*}{$\begin{array}{l}\text { All agri- } \\
\text { eultural } \\
\text { pursnits* }\end{array}$} & \multicolumn{3}{|c|}{ Agricultural Laborers $†$} & \multirow{2}{*}{$\begin{array}{l}\text { Dairymen } \\
\text { and dairy- } \\
\text { women }\end{array}$} & \multirow{2}{*}{$\begin{array}{c}\text { Farmers } \\
\text { and } \\
\text { planters }\end{array}$} \\
\hline & & Total & $\begin{array}{l}\text { Farm and } \\
\text { plantation }\end{array}$ & $\begin{array}{c}\text { Garden and } \\
\text { nursery }\end{array}$ & & \\
\hline La. & 295,445 & 173,510 & 88,198 & 514 & 283 & 112,186 \\
\hline Texas & 644,634 & 273,188 & 104,735 & 635 & 487 & 337,962 \\
\hline Okla. & 94,931 & 27,896 & 10,710 & 48 & 12 & 62,616 \\
\hline Int. T..... & 92,418 & 40,582 & 16,367 & 39 & 29 & 47,947 \\
\hline Ark......... & 345,479 & 156,455 & 56,329 & 248 & 101 & 176,724 \\
\hline Mont & 28,693 & 8,979 & 7,290 & 102 & 57 & 11,536 \\
\hline W5o... & 13,407 & 3,318 & 2,367 & 30 & 8 & 4,652 \\
\hline Colo.... & 44,904 & 14,825 & 10,648 & 444 & 221 & 22,148 \\
\hline N. Mex..... & 27,214 & 7,578 & 5,136 & 70 & 18 & 10,740 \\
\hline Ariz........ & 16,174 & 3,393 & 2,202 & 54 & 48 & 6,918 \\
\hline Utah...... & 29,414 & 8,698 & 3,657 & 217 & 82 & 16,566 \\
\hline Nev.... & 5,890 & 2,760 & 2,283 & 16 & 41 & 1,871 \\
\hline $0 \ldots$ & 27,489 & 7,814 & 4,103 & 58 & 52 & 15,912 \\
\hline Wash...... & 61,113 & 17,455 & 10,964 & 551 & 142 & 32,612 \\
\hline Ore... & 58,490 & 17,316 & 9,741 & 419 & 167 & 33,168 \\
\hline Cal.... & 152,371 & 67,493 & 51,280 & 4,227 & 2,345 & 61,753 \\
\hline Alaska..... & 367 & & & & 5 & 17 \\
\hline Hawaii. & 56,056 & 48,469 & 47,962 & 343 & 51 & 5,238 \\
\hline
\end{tabular}

* Classified under agricultural pursuits are gardeners, florists, nurserymen, etc. 62,417; lumbermen, raftsmen and woodehoppers, 108,451; stock raisers, herdsmen and drovers, 85,463; turpentine farmers aud laborers, 24,737; apiarists, 1,375; other agricultural pursuits not specified, 4,231.

† The difference between the total number of agricultural laborers and the number Included under farm and plantation, garden and nursery, is made up of $\mathbf{2 . 3 6 6 , 3 1 3}$ members of families acting as agrieultural laborers.

\Not including farm and plantation overseers, 18,101; milk farmers, 5,207; and members of families acting as farmers, planters and overseers, 169,053 . 
II. FARM ACREAGE

\begin{tabular}{|c|c|c|c|c|c|c|c|}
\hline \multirow{2}{*}{$\begin{array}{l}\text { States } \\
\text { and terri- } \\
\text { tories }\end{array}$} & \multirow{2}{*}{ 葱 } & \multirow{2}{*}{$\begin{array}{l}\text { Acres of } \\
\text { cereals }\end{array}$} & \multirow{2}{*}{$\begin{array}{l}\text { Acres of } \\
\text { all crops }\end{array}$} & \multirow{2}{*}{$\begin{array}{l}\text { Value of all } \\
\text { crops }\end{array}$} & \multirow{2}{*}{$\begin{array}{l}\text { Value of } \\
\text { cereals }\end{array}$} & \multicolumn{2}{|c|}{$\begin{array}{l}\text { A verage value } \\
\text { per acre of }\end{array}$} \\
\hline & & & & & & All Crops & Cereals \\
\hline U.S. & & $184,994,588$ & $289,821,549$ & $\$ 2,910,138,663$ & $\$ 1,484,231,038$ & $\$ 1004$ & $\$ 802$ \\
\hline Als & 25 & $3,088,454$ & $6,792,368$ & 70,696 & $18,424,318$ & 1041 & 597 \\
\hline & $\begin{array}{l}52 \\
47\end{array}$ & 53958 & 150.8 & $\begin{array}{r}6,603 \\
2,423,471\end{array}$ & 673.639 & $\begin{array}{ll}63 & 49 \\
16 & 06\end{array}$ & 1248 \\
\hline & 20 & $2,980,684$ & 5,2 & $56,803,494$ & 20,2 & 1084 & \\
\hline a) & 18 & $4,004,254$ & $7,030,284$ & $93,641,334$ & $33.674,733$ & 1332 & \\
\hline & 34 & 525,239 & $1,593,962$ & $16.857,533$ & $4,700,271$ & 1058 & 895 \\
\hline on & 43 & 72,0 & 4, & $15,349,869$ & 251,888 & $24 \quad 19$ & 1738 \\
\hline i & 3 & 318,772 & 473,987 & $6,024,879$ & $3,032,513$ & 1271 & \\
\hline & 51 & 543 & 3,233 & 669,159 & 7,039 & 20608 & 1296 \\
\hline Fla & 38 & 607,322 & $1,062,331$ & 12,8 & $2,906,332$ & 1210 & \\
\hline & 22 & 886 & $8,412,907$ & 83,1 & 1,157 & 988 & \\
\hline & 42 & & & & 7,989 & 24515 & 13163 \\
\hline & 36 & & & & 2,387 & $\begin{array}{lll}9 & 39\end{array}$ & \\
\hline & 1 & 16,7 & 20,8 & & 437 & 1017 & \\
\hline & 6 & & & & 25 & 10 & \\
\hline & 32 & 66 & & 2 & 568 & 672 & \\
\hline & 2 & & & & & & \\
\hline $\mathbf{K} \mathbf{a}$ & $\overline{5}$ & & 1 & & & $6 \quad 13$ & \\
\hline & 14 & & & & & 11 & \\
\hline & 27 & & & & & 17 & \\
\hline & 41 & & & & & 11 & 12 \\
\hline & 2 & 55 & & & 14, & & \\
\hline & 4 & & & & & 26 & 17 \\
\hline & 12 & & & & & 10 & \\
\hline & 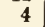 & & & & & & \\
\hline & 23 & & & & & 14 & \\
\hline & 7 & & & & & & \\
\hline & 35 & & & & & & 12 \\
\hline & 10 & $12, \mathrm{C}$ & & & & & \\
\hline & 49 & & & & & & \\
\hline & 46 & & & & & 13 & \\
\hline & 33 & & & & & & \\
\hline & 44 & & & & & & \\
\hline t. & 17 & & & & & & \\
\hline & 21 & & & & & 11 & \\
\hline & 13 & & & & & & \\
\hline & 3 & & & & & 12 & 11 \\
\hline & 24 & & & & & & \\
\hline & 31 & & & & & & \\
\hline & 9 & & & & & & \\
\hline & 50 & & & & & & 1 \\
\hline & 28 & & & & & & \\
\hline & i6 & & & & & & \\
\hline & 15 & & & & & & \\
\hline & 11 & & & & & & \\
\hline & 4 & & & & & & \\
\hline & 39 & & & & & & 15 \\
\hline & 19 & & & & & & \\
\hline & 29 & 1,35 & & 22, & 12,1 & & 9 \\
\hline & 30 & 1,3 & & & & 1080 & \\
\hline & 10 & 5,37 & & & & & 9 \\
\hline & 48 & 50,528 & 435,863 & $3,119,023$ & 528,481 & 716 & 10 \\
\hline
\end{tabular}

*The first column shows the rank of the state or territory when arranged ace cording to the total value of all cereals grown in 1899 .

†Barley, buckwheat, corn. oats, rJe, wheat, rice and Kaffr corn. 
III. RENTED FARMS

\begin{tabular}{|c|c|c|c|c|c|c|}
\hline \multirow{2}{*}{$\begin{array}{l}\text { States, terri- } \\
\text { tories and } \\
\text { foreign } \\
\text { countries in } \\
\text { which owners } \\
\text { reside }\end{array}$} & \multicolumn{6}{|c|}{ Number of rented farms belonging to owners of- } \\
\hline & $\begin{array}{l}\text { Under } 100 \\
\text { acres }\end{array}$ & $\begin{array}{c}100 \text { and } \\
\text { nnder } 200 \\
\text { acres }\end{array}$ & $\begin{array}{l}200 \text { and } \\
\text { under } 500 \\
\text { acres }\end{array}$ & $\begin{array}{c}500 \text { and } \\
\text { nnder } 1,000 \\
\text { acres }\end{array}$ & $\begin{array}{c}1,000 \text { snd } \\
\text { under } 2,500 \\
\text { acres }\end{array}$ & $\begin{array}{c}2,500 \text { scres } \\
\text { 3nd over }\end{array}$ \\
\hline Grand total. & 810,583 & 458,215 & 390,302 & 147,260 & 90,061 & 37,925 \\
\hline Ala.. & 42,781 & 20,473 & 26,623 & $\mathbf{1 5}, 968$ & 11,540 & 4,897 \\
\hline Alaska..... & 48 & 34 & 14 & 1 & 5 & \\
\hline Ariz........ & 280 & 166 & 88 & 26 & 16 & \\
\hline Ark......... & 33,519 & 13,957 & 12,727 & 6,752 & 2,933 & 1,606 \\
\hline Cal.......... & 5,434 & 2,900 & 3,456 & 1,850 & 1,688 & 1,913 \\
\hline Colo......... & 1,729 & 1,981 & 1,525 & 508 & 250 & 301 \\
\hline Conn........ & 2,012 & 826 & 404 & 70 & 54 & 15 \\
\hline Del......... & 1,279 & 1,174 & 1,256 & 480 & 313 & 9 \\
\hline D. of C..... & 699 & 498 & 512 & 218 & 93 & 710 \\
\hline Fla......... & 4,286 & 1,593 & 1,780 & 1,097 & 816 & 239 \\
\hline Ga.......... & 51,832 & 23,686 & 30,790 & 16,957 & 8,347 & 4,297 \\
\hline Hawaii..... & 7 & 4 & 3 & 4 & $\ldots \ldots$ & .. \\
\hline Idaho ....... & 326 & 544 & 308 & 72 & 46 & 66 \\
\hline Ill........... & 34,743 & 31,958 & 27,160 & 6,913 & 3,131 & 1,207 \\
\hline Ind............ & 30,844 & 14,753 & 9,212 & 1,573 & 730 & 117 \\
\hline Ind. Ter.... & 9,759 & 6,426 & 7,852 & 4,692 & 3,219 & 939 \\
\hline Inwa......... & 20,284 & 25,755 & 22,286 & 4,221 & 1,828 & 591 \\
\hline Kan........ & 14,212 & 17,878 & 12,781 & 3,267 & 1,610 & 747 \\
\hline iy.......... & 51,045 & 12,360 & 7,815 & 1,648 & 962 & 290 \\
\hline La.......... & 23,372 & 10,234 & $13,07 i$ & 8,243 & 7,293 & 3,008 \\
\hline Maine........ & 1,408 & 657 & 256 & 20 & 16 & $\ldots$ \\
\hline$M d \ldots . . . .$. & 4,328 & 4,009 & 3,857 & 1,246 & 740 & 125 \\
\hline Mass...... & 2,700 & 1,071 & 634 & 136 & 60 & 6 \\
\hline Mich....... & 17,373 & 8,637 & 3,330 & 409 & 135 & 9 \\
\hline Minn....... & 5,146 & 8,604 & 7,746 & 1,493 & 801 & 219 \\
\hline Miss ....... & 44,267 & 23,337 & 26,036 & 16,477 & 13,878 & 4,129 \\
\hline Mo..... & 41,594 & 20,829 & 15,402 & 3,493 & 1,835 & 683 \\
\hline Mont....... & 273 & 470 & 377 & 165 & 73 & 47 \\
\hline Neb....... & 7,203 & 13,645 & 11,533 & 3,105 & 1,484 & 780 \\
\hline Nev..... & 71 & 58 & 65 & 43 & 20 & 9 \\
\hline N. H. . . & 996 & 539 & 268 & 55 & 12 & 6 \\
\hline N.J........ & 4,580 & 3,121 & 1,353 & 337 & 56 & 33 \\
\hline N. Mex..... & 677 & 269 & 128 & 26 & 37 & 45 \\
\hline N. Y....... & 23,863 & 20.282 & 9,843 & 2,166 & 1,045 & 1,233 \\
\hline N.C.... & 45,366 & 18,123 & 15,998 & 6,096 & 3,237 & 694 \\
\hline N. Dak..... & 221 & 1.120 & 1,438 & 491 & 210 & 45 \\
\hline Ohio........ & 36,218 & 22,935 & 10,434 & 1,753 & 696 & 300 \\
\hline Okla....... & 3,499 & 4,804 & 1,351 & 282 & 104 & 2,043 \\
\hline Ore........ & 1,816 & 1,650 & 1,775 & 568 & 201 & 90 \\
\hline Pa.......... & 27,806 & 18,196 & 8,506 & 1,485 & 644 & 300 \\
\hline R. I...... & 755 & 308 & 158 & 17 & 6 & \\
\hline
\end{tabular}


III. Rented Farms - Concluded.

\begin{tabular}{|c|c|c|c|c|c|c|}
\hline \multirow{2}{*}{$\begin{array}{c}\text { States, terri- } \\
\text { tories and } \\
\text { foreign } \\
\text { countries in } \\
\text { which owners } \\
\text { reside }\end{array}$} & \multicolumn{6}{|c|}{ Number of rented farms belonging to owners of- } \\
\hline & $\begin{array}{l}\text { Under } 100 \\
\text { acres }\end{array}$ & $\begin{array}{c}100 \text { and } \\
\text { under } 200 \\
\text { acres }\end{array}$ & $\begin{array}{l}200 \text { and } \\
\text { under } 500 \\
\text { acres }\end{array}$ & $\begin{array}{c}500 \text { and } \\
\text { under } 1,000 \\
\text { acres }\end{array}$ & $\begin{array}{c}1,000 \text { and } \\
\text { under } 2,500 \\
\text { acres }\end{array}$ & $\begin{array}{l}2,500 \text { acres } \\
\text { and over }\end{array}$ \\
\hline $\begin{array}{l}\text { S. C........ } \\
\text { S. Dak..... } \\
\text { Tenn....... } \\
\text { Texas ....... } \\
\text { Utah...... } \\
\text { Vt......... } \\
\text { Va......... } \\
\text { Wash ...... } \\
\text { W. Va...... } \\
\text { Wis........ } \\
\text { Wyo...... } \\
\text { Foreign } \\
\text { Countries }\end{array}$ & $\begin{array}{r}37,211 \\
697 \\
51,442 \\
74,822 \\
1,137 \\
1,168 \\
22,770 \\
1,426 \\
11,530 \\
9,291 \\
101 \\
\\
337\end{array}$ & $\begin{array}{r}17,762 \\
2,638 \\
16,435 \\
37,038 \\
317 \\
1,474 \\
9,468 \\
1,276 \\
3,423 \\
8,025 \\
201 \\
\\
288\end{array}$ & $\begin{array}{r}18,931 \\
3,352 \\
12,817 \\
35,789 \\
166 \\
1,210 \\
9,528 \\
1,058 \\
2,258 \\
4,670 \\
116 \\
\\
250\end{array}$ & $\begin{array}{r}8,926 \\
1,038 \\
4,614 \\
12,493 \\
45 \\
222 \\
3,733 \\
388 \\
773 \\
506 \\
41 \\
55\end{array}$ & $\begin{array}{r}6,080 \\
502 \\
2,914 \\
7,746 \\
22 \\
80 \\
1,859 \\
213 \\
319 \\
69 \\
19 \\
74\end{array}$ & $\begin{array}{r}1,361 \\
247 \\
1,113 \\
2,206 \\
12 \\
20 \\
579 \\
117 \\
392 \\
10 \\
19\end{array}$ \\
\hline $\begin{array}{l}\text { Canada .... } \\
\text { Great Brit- } \\
\text { ain an } \\
\text { Ireland... } \\
\text { France. .... } \\
\text { Mexico ..... } \\
\text { Germany ... } \\
\text { Austria..... } \\
\text { Cuba....... } \\
\text { Norway ..... } \\
\text { Switzerland } \\
\text { Other For- } \\
\text { eign Coun- } \\
\text { tries...... }\end{array}$ & $\begin{array}{r}68 \\
19 \\
28 \\
12 \\
2 \\
12 \\
3 \\
3\end{array}$ & $\begin{array}{r}79 \\
24 \\
11 \\
13 \\
\cdots \\
8 \\
12 \\
4\end{array}$ & $\begin{array}{r}77 \\
7 \\
20 \\
12 \\
1 \\
2 \\
7 \\
5\end{array}$ & 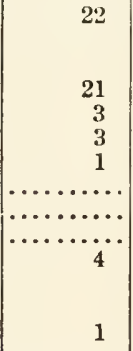 & 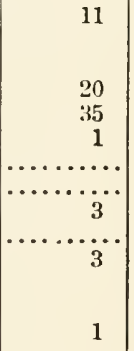 & $\begin{array}{r}r \\
\ldots \ldots \ldots \\
\cdots \ldots \ldots \\
\cdots \cdots\end{array}$ \\
\hline
\end{tabular}




\section{ACREAGE OF RENTED FARMS}

\begin{tabular}{|c|c|c|c|c|c|c|}
\hline \multirow{2}{*}{$\begin{array}{l}\text { State, terri- } \\
\text { tories aud } \\
\text { foreign } \\
\text { countries in } \\
\text { which owners } \\
\text { reside }\end{array}$} & \multicolumn{6}{|c|}{ Acres in rented farms belonging to owners of- } \\
\hline & $\begin{array}{l}\text { Under } \\
100 \\
\text { acres }\end{array}$ & $\begin{array}{l}100 \text { and } \\
\text { under } \\
200 \text { acres }\end{array}$ & $\begin{array}{l}200 \text { and } \\
\text { under } \\
500 \text { acres }\end{array}$ & $\begin{array}{c}500 \text { and } \\
\text { under } \\
1,000 \text { acres }\end{array}$ & $\begin{array}{c}1,000 \text { and } \\
\text { nnder } \\
2,500 \text { acres }\end{array}$ & $\begin{array}{l}2,500 \text { acres } \\
\text { and } \\
\text { over }\end{array}$ \\
\hline Grand total. & $30,620,014$ & $46,544,292$ & $53,465,812$ & $20,880,980$ & $13,676,080$ & $19,471,012$ \\
\hline Ala. & $1,284,703$ & $1,201,083$ & $1,696,184$ & $1,001,320$ & 746,456 & 360,0 \\
\hline Alaska..... & 2,055 & 4,716 & 4,549 & 517 & 6,900 & \\
\hline Ariz........ & 11,759 & 23,353 & 17,788 & 10,926 & 3,103 & 11,664 \\
\hline Ark........ & $1,037,531$ & 980,506 & 890,877 & 402,771 & 238,495 & \\
\hline Cal... & 192,127 & 399,911 & 917,127 & 935,032 & $1,402,999$ & 2,84 \\
\hline Colo.. & 75,972 & 297,811 & 378,693 & 208,099 & 137,514 & 704,535 \\
\hline Conn. & 75,677 & 102,724 & 93,767 & 26,1 & 12,215 & 6,105 \\
\hline Del... & 65,800 & 139,217 & 216,606 & 97 & 65,677 & \\
\hline D. of C..... & 24,307 & 58,384 & 95,194 & 47,123 & 26,232 & 145,878 \\
\hline Fla......... & 133,571 & 124,033 & 153,484 & 89,346 & 75,237 & 07 \\
\hline Ga. & $1,697,575$ & $1,664,128$ & $2,918,568$ & $1,768,022$ & $1,131,318$ & 613,138 \\
\hline Hawa & 374 & 630 & 768 & 600 & 198 & 85 \\
\hline Idaho... & 17,385 & 80,374 & 85,372 & 31,503 & 18,862 & \\
\hline $111 \ldots .$. & $1,758,196$ & $3,910,928$ & $5,205,735$ & $1,477,509$ & 702,047 & 506,444 \\
\hline Ind.......... & $1,529,242$ & $1,854,032$ & $1,568,817$ & 328,431 & 161,639 & 67 , \\
\hline Ind. Ter.... & 357,929 & 469,580 & 749,075 & 553,945 & 442,598 & $1,306,794$ \\
\hline Iowa........ & $1,142,698$ & $3,501,650$ & $4,723,198$ & $1,084,161$ &, 424 & 152,149 \\
\hline Kan. & 794,279 & $2,536,646$ & $2,650,351$ & 976,377 & 555,284 & 445,213 \\
\hline Ky.. & $1,362,541$ & $1,100,854$ & $1,056,204$ & 228,482 & 127,518 & 315 \\
\hline La..... & 614,403 & 481,701 & 642,454 & 396,861 & 409,137 & 182,600 \\
\hline Maine. & 64,883 &, 682 & 54,433 & 10,7 & 4,730 & \\
\hline . & 184,746 & 501,113 & 677,830 & 302,450 & 171,333 & 40,109 \\
\hline$\cdots$ & 102,242 & 119,644 & 136,743 & 37,295 & 30,453 & 20,690 \\
\hline$\cdots$ & 857,631 & $1,104,531$ & 691,358 & 117,800 & 43,732 & 11,681 \\
\hline . . . . . & 297,313 & $1,261,418$ & $1,921,447$ & 514,683 & 254,598 & 91,567 \\
\hline iss.... & $1,184,569$ & $1,106,653$ & $1,351,996$ & 37 & 78 & 201,587 \\
\hline Io. & $1,730,457$ & $2,345,555$ & $2,349,164$ & 678 & 326,013 & 274,489 \\
\hline ...... & 13,854 & 70,139 & 106,180 & 86, & 63,131 & 524,343 \\
\hline Neb. & 439,320 & $1,944,600$ & $2,491,348$ & 902,375 & 441,269 & 307,392 \\
\hline $\mathrm{Nev}$ & 2,569 & 7,869 & 17,368 & 24,400 & 23,676 & 17,096 \\
\hline N. 1 & 41,088 & 68,9 & 9 & 20 & 89 & 22,056 \\
\hline N. & 202,399 & 363,757 & 251,073 & 70,0 & 32,878 & 8.154 \\
\hline N. 1 & 16,443 & 34,232 & 23,993 & 11,287 & 21,943 & 145,607 \\
\hline N. Y. . & $1,394,690$ & $2,590,431$ & $2,050,461$ & 470.597 & 271,416 & 472,390 \\
\hline N. C.. & $1,389,562$ & $1,404,787$ & $1,714,419$ & 799,274 & 496,530 & 111,114 \\
\hline N. I & 11,23 & & & & 140, & 49,029 \\
\hline Ohio & $1,823,927$ & $2,787,732$ & $1,828,212$ & 346 , & 149,088 & 98,699 \\
\hline Okla.. & 170,429 & 695,763 & 294,503 & 103,157 & 64,637 & 938,708 \\
\hline Ore & 71,206 & 239,954 & 505,666 & 289 & 183,755 & 94,238 \\
\hline Penna. & $1,350,338$ & $2,402,689$ & $1,537,406$ & 359,091 & 204,419 & 237,025 \\
\hline re & 28,492 & 36,092 & 31,969 & 9,2 & 18 & 2,994 \\
\hline
\end{tabular}




\section{The Farmer's Business Handbook}

IV. Acreage of Rented Farms-Concluded

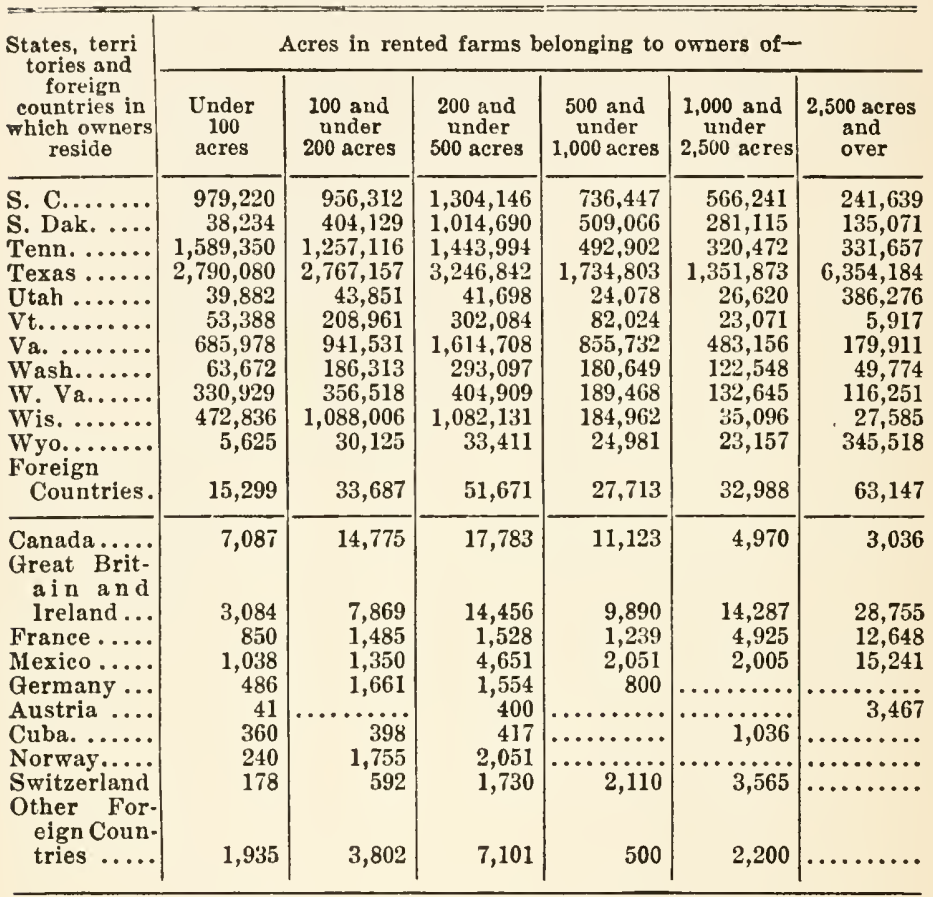




\section{VALUE OF RENTED FARMS}

\begin{tabular}{|c|c|c|c|c|c|c|}
\hline \multirow{2}{*}{$\begin{array}{c}\text { States, } \\
\text { territor. } \\
\text { ties and } \\
\text { foreign } \\
\text { co'tries } \\
\text { where } \\
\text { owners } \\
\text { reside }\end{array}$} & \multicolumn{6}{|c|}{ Value of rented farms belonging to owners of - } \\
\hline & $\begin{array}{c}\text { Under } 100 \\
\text { acres }\end{array}$ & $\begin{array}{l}100 \text { and } \\
\text { under } 200 \\
\text { acres }\end{array}$ & $\begin{array}{l}200 \text { and } \\
\text { under } 500 \\
\text { acres }\end{array}$ & $\begin{array}{c}500 \text { and } \\
\text { under } 1,000 \\
\text { acres }\end{array}$ & $\begin{array}{c}1,000 \text { and } \\
\text { under } 2,500 \\
\text { acres }\end{array}$ & $\begin{array}{l}2,500 \text { acres } \\
\text { and over }\end{array}$ \\
\hline$\underset{\text { total }}{\text { Grand }}$ & $\$ 992,813,125$ & $\$ 1,357,881,226$ & $\$ 1,374,513,102$ & $\$ 117,456,058$ & $\$ 233,180,388$ & $\$ 148,455,226$ \\
\hline $\begin{array}{l}\text { Ala .... } \\
\text { Alaska. }\end{array}$ & $\begin{array}{r}11,721,827 \\
84,486\end{array}$ & $\begin{array}{r}8,830,154 \\
136,760\end{array}$ & $\begin{array}{r}12,853,494 \\
72,660\end{array}$ & $\begin{array}{r}7,821,912 \\
4,000\end{array}$ & $\begin{array}{r}5,893,459 \\
50,740\end{array}$ & $2,544,748$ \\
\hline Ariz.... & 432,152 & 500.115 & 430,906 & 166,622 & 28,906 & $34,0 i i$ \\
\hline Ark. & $12,602,790$ & $9,065,422$ & $9,972,583$ & $5,857,173$ & $3,525,229$ & $1,338,681$ \\
\hline Cal... & $23,056,419$ & $18,333,589$ & $30,327,561$ & $24,801,820$ & $30,754,604$ & $44,263,048$ \\
\hline Colo... & $4,267,129$ & $7,295,038$ & $8,621,019$ & $3,643,425$ & $2.682,013$ & $2,158,281$ \\
\hline Conn... & $5,180,187$ & $2,985,363$ & $2,902,540$ & 439,093 & 201,570 & $\mathbf{4 3 , 6 0 9}$ \\
\hline Del.... & $2,807,580$ & $4,361,209$ & $6,138,536$ & $2,732,106$ & $1,318,869$ & 68,714 \\
\hline D. of C. & $3,215,781$ & $2,406,476$ & $2,263,126$ & 958,544 & 184,077 & $4,937,217$ \\
\hline Fla..... & $1,587,178$ & 980,660 & $1,085,882$ & 486,972 & 353,551 & 83,200 \\
\hline Ga. & $19,110,245$ & $14,038,476$ & $22,551,662$ & $11,466,449$ & $7,168,988$ & $3,210,271$ \\
\hline Hawsii. & 39,550 & 13,700 & 17,100 & 18,600 & & \\
\hline Idaho. . & 621,876 & $1,342,105$ & $1,400,871$ & 533,087 & 22 & 2 \\
\hline Ill.. & $100,958,519$ & $229,073,202$ & $284,995,768$ & $78,661,097$ & 36,46 & $18,566,298$ \\
\hline Ind & $64,356,271$ & $64,424,846$ & $64,659,647$ & $12,767,484$ & $\mathbf{5}, \mathbf{7 5 5}, 9$ & $1,282,942$ \\
\hline Ind. Ty. & $3,879,679$ & $4,174,642$ & $5,922,569$ & $3,817,199$ & $2,895,415$ & $6,043,076$ \\
\hline Iowa... & $52,413,058$ & $148,115,459$ & $181,380,691$ & 6,897 & $15,793,392$ & $3,859,391$ \\
\hline Kan.... & $22,869,980$ & $\begin{array}{l}57,179,071 \\
\end{array}$ & $50,703,256$ & $15,972,010$ & $7,813,204$ & $3,513,494$ \\
\hline Ky.... & $31,285,184$ & $22,235,4$ & $23,863,066$ & $5,603,683$ & 5,623 & 327,088 \\
\hline La... & $9,859,665$ & $6,317,671$ & $9,058,274$ & $6,552,093$ & $15,133,570$ & $2,263,377$ \\
\hline Maine. & $1,547,861$ & $1,001,525$ & 689,778 & 152,831 & 45,534 & \\
\hline Md.... & $9.682,5$ & $17,715.2$ & $21,702, \mathrm{C}$ & $7,759,310$ & $3,527,822$ & 618,767 \\
\hline Mass... & $8,307,4$ & $3,422,915$ & $3,020,461$ & 550,680 & 364,480 & 76,435 \\
\hline Mteh... & $38,759,243$ & $39,898,0$ & $22,956,885$ & $3,722,841$ & 78 & 82,475 \\
\hline Minn.. & 11,6 & 38 & 5 & 12,7 & 5.7 & $2,396,549$ \\
\hline Miss... & $13,358,824$ & $10,499,2$ & $14,193,551$ & 3,914 & $8,466,298$ & $3,117,728$ \\
\hline Mo & $60,741,3$ & 61 & 4 & 18 & 6,9 & $3,138,278$ \\
\hline Mont... & 492,409 & $1,353,969$ & $1,786,927$ & $1,301,900$ & 609,282 & $1.151,770$ \\
\hline Neb.... & $15,964,482$ & $53,356,981$ & $62,293,804$ & $18,994,695$ & $8,094,207$ & $3,806,713$ \\
\hline & 152,834 & 208,7 & 314,113 & 222,264 & 242,473 & 153.531 \\
\hline N. & $1,472,299$ & $1,164,818$ & 859,941 & 243,428 & 56,111 & 122,325 \\
\hline f... & $16,463,266$ & $16,302,1$ & $7,083,300$ & $2,049,928$ & 543,485 & 183,136 \\
\hline N. Mex. & 440,780 & 465,356 & 359,044 & $\begin{array}{l}0.78,398 \\
138,398\end{array}$ & 204,776 & 186,030 \\
\hline N.Y... & $79,486,882$ & $96,339,050$ & $63,456,085$ & $10,953,108$ & $5,478,212$ & $4,415,798$ \\
\hline N. C... & $15,773,939$ & $12,8^{*} \times 6,3$ & $14,612,4$ & $5,914,918$ & $3,452,658$ & 578,291 \\
\hline N. Dak & 331,286 & $2,884,797$ & 8.165 .879 & $4,374,500$ & $2,509,262$ & 698,084 \\
\hline Ohio... & $92,080,177$ & $114,385,894$ & $81,967,981$ & $13,195,377$ & $4,720.997$ & $1,839,267$ \\
\hline okls.. & $2,504,678$ & $8,226,593$ & $3,640,050$ & 959,814 & 506,813 & $4,692,672$ \\
\hline Ore..... & 3,95 & 5,02 & $9.554,2$ & 4,198,164 & $2,054,816$ & 699,257 \\
\hline Pa.... & $102,131,443$ & $113,723,457$ & $66,547,515$ & $12,583,606$ & $4,641,323$ & $3,015,515$ \\
\hline R. I.... & $2,605,827$ & $1,452,2$ & 855,013 & 200,840 & 39,008 & 12,002 \\
\hline C..... & $12,895,994$ & $10,058,952$ & $12,666,945$ & $6,402,817$ & $4,153.700$ & $1,203,564$ \\
\hline S. Dak. & $1,179.260$ & $7,875,144$ & 16,620600 & $6,372,067$ & $2,794,533$ & $1.205,673$ \\
\hline Tenn... & $27,126,321$ & $17,216,532$ & $16,304,352$ & $6,590,339$ & $3,948,413$ & $1,956,498$ \\
\hline Teras.. & $48,179,408$ & $44,506,898$ & 50,817508 & $24,583,386$ & $15,656,517$ & $13,487,266$ \\
\hline
\end{tabular}




\section{The Farmer's Business Handbook}

V. Value of Rented Farms - Concluded

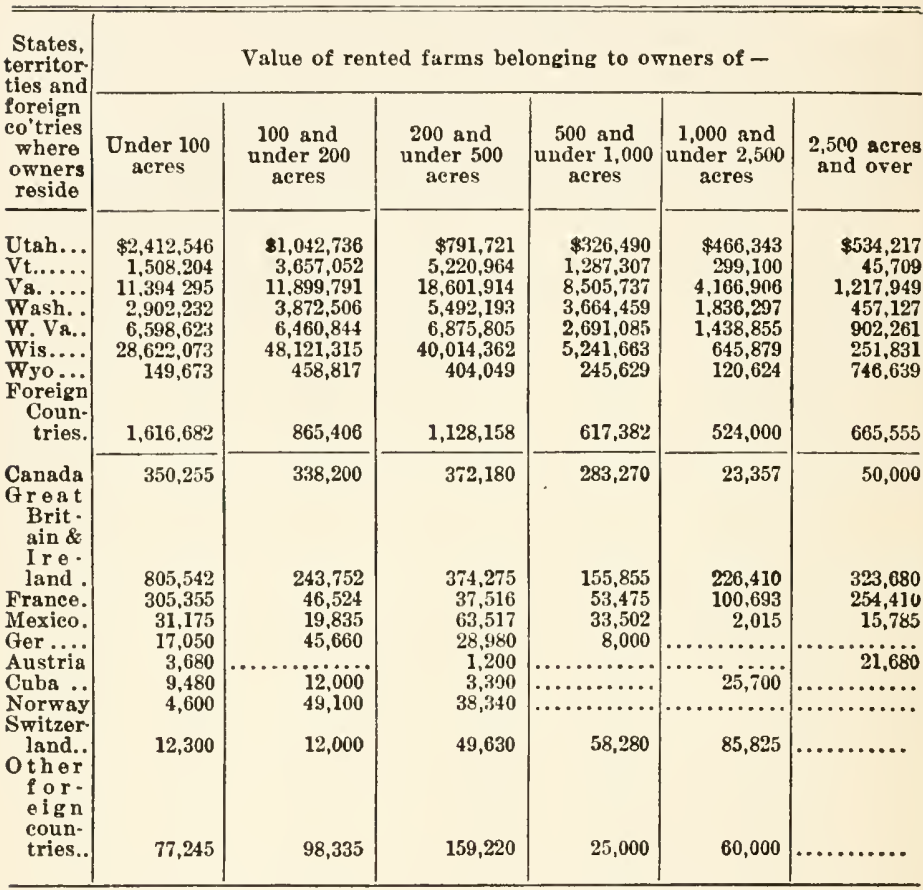


VI. OWNERS OF RENTED FARMS

\begin{tabular}{|c|c|c|c|c|c|c|}
\hline \multirow{2}{*}{$\begin{array}{l}\text { States, terri- } \\
\text { tories and } \\
\text { foreign } \\
\text { conntries in } \\
\text { which owners } \\
\text { reside }\end{array}$} & \multicolumn{6}{|c|}{ Number of owners of rented farms who possess: } \\
\hline & $\begin{array}{c}\text { Under } 100 \\
\text { acres }\end{array}$ & $\begin{array}{l}100 \text { and } \\
\text { under } 200 \\
\text { acres }\end{array}$ & $\begin{array}{l}200 \text { and } \\
\text { under } 500 \\
\text { acres }\end{array}$ & $\begin{array}{c}500 \text { and } \\
\text { under } 1,000 \\
\text { acres }\end{array}$ & $\begin{array}{c}1,000 \text { and } \\
\text { under } 2,500 \\
\text { acres }\end{array}$ & $\begin{array}{c}2,500 \text { acres } \\
\text { and over }\end{array}$ \\
\hline Grand total. & 696,259 & 331,993 & 186,170 & 31,410 & 9,631 & 2,253 \\
\hline Ala........ & 32,745 & 8,646 & 5,629 & 1,480 & 522 & 90 \\
\hline Alaska..... & 47 & 33 & 13 & 1 & 5 & \\
\hline Ariz........ & 265 & 158 & 58 & 17 & 2 & 2 \\
\hline Ark. . . . . & 26,259 & 6,818 & 3,109 & 602 & 170 & 29 \\
\hline $\mathrm{Cal} . . . \ldots . .$. & 5,259 & 2,746 & 2,899 & 1,358 & 933 & $\$ 52$ \\
\hline Colo......... & 1,621 & 1,903 & 1,212 & 295 & 100 & 46 \\
\hline Conn....... & 1,967 & 764 & 331 & 40 & 9 & 2 \\
\hline Del......... & 1,244 & 1,030 & 753 & 148 & 45 & 1 \\
\hline D. of C..... & 629 & 414 & 320 & 75 & 18 & 7 \\
\hline Fla......... & 3,594 & 889 & 514 & 136 & 47 & 6 \\
\hline Ga........... & 41,155 & 12,721 & 10,120 & 2,681 & 812 & 150 \\
\hline Hawaii..... & & 4 & 3 & 1 & & \\
\hline Idaho ...... & 317 & 531 & 280 & 45 & 13 & 6 \\
\hline III........... & 33,176 & 28,626 & 18,159 & 2,263 & 500 & 79 \\
\hline Ind......... & 29,613 & 12,628 & 5,737 & 503 & 115 & 13 \\
\hline Ind. Ter.... & 7,891 & 3,351 & 2,465 & 833 & 314 & 129 \\
\hline lowa........ & 19,748 & 23,846 & 16,614 & 1,670 & 353 & 38 \\
\hline Kan......... & 13,740 & 16,554 & 9,118 & 1,450 & 374 & 68 \\
\hline Ky........ & 42,777 & 8,364 & 3,763 & 346 & 92 & 14 \\
\hline La ......... & 16,732 & 3,479 & 2,157 & 593 & 274 & 44 \\
\hline Malne...... & 1,391 & 632 & 209 & 17 & 4 & \\
\hline Md......... & 4,176 & 3,722 & 2,695 & 461 & $12 \pi$ & 10 \\
\hline Mass. ....... & 2,647 & 1,000 & 488 & 59 & 23 & 4 \\
\hline Mlch....... & 17,173 & 8,173 & 2,582 & 185 & 32 & 4 \\
\hline Minn.... & 5,085 & 8,400 & 6,713 & 780 & 179 & 23 \\
\hline Miss ....... & 31,296 & 7,714 & 4,269 & 1,117 & 420 & 53 \\
\hline Mo...... & 38,642 & 16,865 & 9,307 & 1,034 & 239 & 40 \\
\hline Mont. . . & 261 & 459 & 334 & 129 & 49 & 14 \\
\hline Neb... & 7,040 & 12,898 & 8,324 & 1,294 & 316 & 48 \\
\hline Ner.... & 68 & 53 & 60 & 36 & 16 & 5 \\
\hline N. H. . & 985 & 524 & 240 & 31 & 6 & 4 \\
\hline N. J.... & 4,441 & 2,846 & 890 & 116 & 23 & 3 \\
\hline N. Mex..... & 588 & 231 & 83 & 18 & 14 & 9 \\
\hline N. $\mathrm{Y} \ldots$ & 23,341 & 19,175 & 7,497 & 708 & 194 & 62 \\
\hline N. C ... & 36,879 & 10,659 & 5,949 & 1,229 & 345 & 31 \\
\hline N. Dak..... & 217 & 1,108 & 1,359 & 380 & 98 & 14 \\
\hline Ohio....... & 34,939 & 20,536 & 6,672 & 534 & 107 & 21 \\
\hline Okla.... & 3,317 & 4,505 & 977 & 152 & 44 & 33 \\
\hline Ore........ & 1,772 & 1,609 & 1,616 & 439 & 133 & 25 \\
\hline$P_{a} \ldots . . . . .$. & 27,262 & 16,607 & 5,671 & 545 & 140 & 41 \\
\hline R. I ........ & 740 & 277 & 122 & 14 & 3 & 1 \\
\hline
\end{tabular}




\section{OWners of Rented Farms-Concluded}

\begin{tabular}{|c|c|c|c|c|c|c|}
\hline \multirow{2}{*}{$\begin{array}{l}\text { States, terri- } \\
\text { tories and } \\
\text { foreign } \\
\text { conntries in } \\
\text { which owners } \\
\text { reside }\end{array}$} & \multicolumn{6}{|c|}{ Number of owners of rented farms who possess: } \\
\hline & $\begin{array}{l}\text { Under } 100 \\
\text { acres }\end{array}$ & $\begin{array}{l}100 \text { and } \\
\text { under } 200 \\
\text { acres }\end{array}$ & $\begin{array}{l}200 \text { and } \\
\text { under } 500 \\
\text { acres }\end{array}$ & $\begin{array}{c}500 \text { and } \\
\text { under } 1,000 \\
\text { acres }\end{array}$ & $\begin{array}{c}1,000 \text { and } \\
\text { under } 2,500 \\
\text { acres }\end{array}$ & $\begin{array}{l}2,500 \text { acres } \\
\text { and over }\end{array}$ \\
\hline $\mathrm{C}$ & 26,466 & 6,937 & 4,359 & 1,099 & 394 & 63 \\
\hline S. Dak & 679 & 2,5 & 3,082 & 746 & 206 & 32 \\
\hline Tenn....... & 43,041 & 9,287 & 4,811 & 755 & 232 & 46 \\
\hline Texas. . & 62,299 & 20,790 & 11,230 & 2,601 & 955 & 371 \\
\hline Utah .. & 1,113 & 307 & 146 & 36 & 18 & 10 \\
\hline $\mathbf{V t} \ldots$ & 1,154 & 1,437 & 1,079 & 130 & 18 & 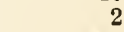 \\
\hline Va. & 19,405 & 7,047 & 5,547 & 1,306 & 355 & 41 \\
\hline Wash. & 1,386 & 1,242 & 938 & 260 & 38 & 15 \\
\hline W. Va. & 10,080 & 2,698 & 1,413 & 292 & 93 & 19 \\
\hline Wis.... & 9,181 & 7,730 & 3,980 & 291 & 26 & 2 \\
\hline Wyo.. & 99 & 197 & 106 & 37 & 15 & 13 \\
\hline \multirow{2}{*}{$\begin{array}{l}\text { Foreign } \\
\text { Countries. }\end{array}$} & & & & & & \\
\hline & 310 & 236 & 168 & 42 & 21 & 12 \\
\hline \multirow{3}{*}{$\begin{array}{c}\text { Canada..... } \\
\text { Great Brit- } \\
\text { ain an d } \\
\text { Ireland... }\end{array}$} & 141 & 103 & 60 & 16 & 3 & 1 \\
\hline & & & & & & \\
\hline & 57 & 5 & 48 & 15 & 10 & \\
\hline France..... & 16 & 12 & 4 & 2 & 3 & 2 \\
\hline Mexico & 25 & 10 & 14 & 3 & 1 & \\
\hline Germany... & 12 & 12 & 5 & 1 & $\ldots \ldots \ldots \ldots$ & \\
\hline Austria..... & 2 & $\ldots$ & 1 & $\ldots$ & .......... & 1 \\
\hline Cuba... & 8 & 3 & 2 & $\ldots \ldots$ & 1 & ..... \\
\hline Norway & 3 & 12 & 7 & $\ldots \ldots$ & $\ldots$ & .......... \\
\hline Switzerland & 3 & 4 & 5 & 4 & 2 & ........... \\
\hline Other For- & & & & & & \\
\hline tries.... & 43 & 26 & 22 & 1 & 1 & $\ldots \ldots$ \\
\hline
\end{tabular}


VII. ANIMALS IN BARNS AND ENCLOSURES

Number of specified domestic animals in barns and enclosures, not on farms or ranges, June 1, 1900, by states and territories

\begin{tabular}{|c|c|c|c|c|c|c|}
\hline \multirow[b]{2}{*}{$\begin{array}{l}\text { States and } \\
\text { territories }\end{array}$} & \multicolumn{2}{|c|}{ Neat Cattle } & \multirow[b]{2}{*}{$\begin{array}{c}\text { Total } \\
\text { Horses } \\
21,216,888\end{array}$} & \multirow[b]{2}{*}{$\begin{array}{c}\text { Total } \\
\text { Mules } \\
3,445,029\end{array}$} & \multirow[b]{2}{*}{$\begin{array}{c}\text { Total } \\
\text { Sheup } \\
61,837,112\end{array}$} & \multirow[b]{2}{*}{$\begin{array}{c}\text { Total } \\
\text { Swine } \\
64.694,222\end{array}$} \\
\hline & $\begin{array}{l}\text { Calves un- } \\
\text { der one; ail } \\
\text { bulls and } \\
\text { steers over } \\
\text { one year }\end{array}$ & $\begin{array}{l}\text { Heifers, } \\
\text { dairy cows: } \\
\text { other cows } \\
\text { two years } \\
\text { and over }\end{array}$ & & & & \\
\hline Ala.. & 22,365 & 27,371 & 18,675 & 7,362 & 6,404 & 51,018 \\
\hline $\begin{array}{l}\text { Alaska } \\
\text { Ariz... }\end{array}$ & 550 & 1,688 & 6,390 & $\dddot{731}$ & $\ddot{123}$ & 712 \\
\hline Ark. . & 19,967 & 25,773 & 25,510 & 7,383 & 2,666 & 53,010 \\
\hline Cal... & 12,732 & 21,862 & 94 , & 3,479 & 18,231 & 24,029 \\
\hline Colo......... & 7,462 & 13,191 & 36,763 & 2,412 & 763 & 3,047 \\
\hline Conn. & 1,106 & 6,868 & 40,659 & 47 & 149 & 4,890 \\
\hline Del. & 127 & 1,113 & 6,702 & 297 & 11 & 4,130 \\
\hline D. of C..... & 20 & 595 & 11,599 & 276 & 30 & 332 \\
\hline Fla ........ & 5,945 & 8,357 & 7,5 & 3,258 & 886 & 15,622 \\
\hline Ga.... & 12,957 & 24,929 & 21,104 & 7,600 & 5,762 & 40,157 \\
\hline $\begin{array}{l}\text { Hawai } \\
\text { Idaho }\end{array}$ & $\ddot{2,043}$ & $\cdots \cdots, 640$ & $\ddot{12}, \ddot{208} \ddot{s}$ & $\ddot{507}$ & $\ddot{1,044}$ & $3 \ddot{467}$ \\
\hline I11..... & 52,634 & 62,400 & 242, & 6,468 & 54,891 & 166,944 \\
\hline Ind & 16,347 & 2 & 128 , & 4,4 & 6,309 & 77,395 \\
\hline Ind. Ter... & 8,535 & 0 & 20 & 3,2 & 338 & 23,954 \\
\hline lowa. & 18,309 & 61,671 & 154,775 & 5,238 & 2,857 & 128,138 \\
\hline Kans.. & 19,170 & 42,394 & 92,956 & 4,025 & 2,032 & 73,170 \\
\hline Ку..... & 11,549 & 24,9 & 45 , & 7,4 & 3,489 & 54,452 \\
\hline ... & 13,362 & 15 & 26 , & 7,012 & 2,099 & 24,392 \\
\hline ... & 2,342 & 1 & 34 , & 50 & 7 , & 9,545 \\
\hline$d \ldots$. & 2,734 & 11,330 & 39, & 2,223 & & 41,910 \\
\hline .. & 1,764 & 7 & 133 & 490 & 2,259 & 17,219 \\
\hline ... & 8,632 & & 102, & 380 & 5,474 & 22,908 \\
\hline$\cdots$ & 7,653 & 38 & 85 & 827 & 4,128 & 17,845 \\
\hline Miss... & 17,259 & 20,760 & 15 , & 4,362 & 3,119 & 23,126 \\
\hline lo. ... & 30,720 & 53,550 & 129,513 & 12,742 & 8,707 & 109,678 \\
\hline Mont... & 2,143 & 4,315 & 17,275 & 361 & 97 & 933 \\
\hline$\ldots$ & 13,759 & 30,240 & 68,6 & 2,800 & 6,026 & 93,094 \\
\hline $\mathrm{Ne}$ & 311 & 746 & 3,3 & .340 & 71 & 491 \\
\hline N. H. . & 550 & 4,529 & 22,367 & 30 & 589 & 5,759 \\
\hline N. J... & 5,857 & 11,548 & 83,191 & 1,123 & 10,301 & 25,954 \\
\hline N. Mex.... & 1,810 & 3,121 & & 637 & 3,060 & 1,440 \\
\hline $\mathbf{Y . . .}$ & 15,292 & 40,263 & 305,937 & 1,866 & 18,048 & 52,176 \\
\hline$\because$ & 5,473 & 15,426 & 15,780 & 3,176 & 1,122 & 40,009 \\
\hline N. Dak.... & 2,990 & 6,663 & 16,114 & 235 & 439 & $3,016^{\circ}$ \\
\hline Ohio........ & 10,002 & 54,600 & 189,965 & 4,772 & 9,393 & 97,226 \\
\hline
\end{tabular}


VII. Animals in Barns and Enclosures - Concluded

\begin{tabular}{|c|c|c|c|c|c|c|}
\hline \multirow[b]{2}{*}{$\begin{array}{l}\text { States and } \\
\text { territories }\end{array}$} & \multicolumn{2}{|c|}{ Neat Cattle } & \multirow[b]{2}{*}{$\begin{array}{c}\text { Total } \\
\text { Horses } \\
21,216,888\end{array}$} & \multirow[b]{2}{*}{$\begin{array}{c}\text { Total } \\
\text { Mules } \\
3,445,029\end{array}$} & \multirow[b]{2}{*}{$\begin{array}{c}\text { Total } \\
\text { Sheep } \\
61,837,112\end{array}$} & \multirow[b]{2}{*}{$\begin{array}{c}\text { Total } \\
\text { Swine } \\
64,694,222\end{array}$} \\
\hline & $\begin{array}{l}\text { Calves un- } \\
\text { der one; all } \\
\text { bulls and } \\
\text { steers over } \\
\text { one year }\end{array}$ & $\begin{array}{l}\text { Heifers, } \\
\text { dairy cows: } \\
\text { other cows } \\
\text { two years } \\
\text { and over }\end{array}$ & & & & \\
\hline Okla. & 2,089 & 4,908 & 15,688 & 1,739 & 40 & 6,102 \\
\hline Ore........ & 4,222 & 11,074 & 20,027 & 510 & 2,476 & 5,135 \\
\hline $\mathrm{Pa} \ldots$ & 15,224 & 85,121 & 220,255 & 22,210 & 10,067 & 157,346 \\
\hline R. I... & 132 & 1,511 & 19,980 & 9 & 78 & 1,360 \\
\hline s. C......... & 4,100 & 11,159 & 9,855 & 2,832 & 522 & 12,030 \\
\hline S. Dak. .... & 4,584 & 10,791 & 24,945 & 509 & 428 & 9,133 \\
\hline Tenn....... & 16,852 & 33,518 & 39,216 & 10,591 & 3,266 & 82,912 \\
\hline Texas...... & 60,791 & 106,624 & 124,431 & 19,370 & 9,496 & 113,267 \\
\hline Utah ....... & 3,269 & 9,662 & 13,002 & 161 & 3,415 & 6,036 \\
\hline$V t \ldots$. & 1,217 & 7,184 & 20,365 & 31 & $94 \overline{5}$ & 5,420 \\
\hline $\mathrm{Va} \ldots .$. & 6,826 & 21,565 & 28,094 & 3,102 & 2,685 & 52,829 \\
\hline Wash & 5,738 & 13,383 & 22,459 & 407 & 1,115 & 5,569 \\
\hline W. Va...... & 3,214 & 12,548 & 18,097 & 3,495 & 1,836 & 22,185 \\
\hline Wis.... & 7,630 & 36,541 & 85,737 & 457 & 3,795 & 27,463 \\
\hline Wyo........ & 836 & 1,850 & 9,371 & 820 & 152 & 139 \\
\hline
\end{tabular}




\section{NUMBER OF DOMESTIC ANIMALS}

Number of specified domestic animals on farms and ranges, to 100,000 acres of farm land, June 1, 1900, by states and territories

\begin{tabular}{|c|c|c|c|c|c|c|}
\hline \multirow{2}{*}{$\begin{array}{l}\text { States and } \\
\text { territories }\end{array}$} & \multicolumn{6}{|c|}{ Domestic animals } \\
\hline & $\begin{array}{l}\text { All neat } \\
\text { cattle }\end{array}$ & Horses & $\begin{array}{l}\text { Mules, } \\
\text { asses and } \\
\text { burros }\end{array}$ & Sheep & Swine & Goats \\
\hline Ala......... & 3,866 & 738 & 938 & 1,533 & 6,881 & 568 \\
\hline $\begin{array}{l}\text { Alaska ..... } \\
\text { Ariz....... }\end{array}$ & $\ddot{38,373}$ & $\ddot{6,462}$ & 450 & $\cdots$ & $\cdots \cdots \cdots$ & \\
\hline $\begin{array}{l}\text { Ariz......... } \\
\text { Ark......... }\end{array}$ & $\begin{array}{r}38,373 \\
5,377\end{array}$ & $\begin{array}{l}0,402 \\
1,524\end{array}$ & $\begin{array}{r}400 \\
1,067\end{array}$ & $\begin{array}{r}4,183 \\
1,544\end{array}$ & $\begin{array}{r}935 \\
10,298\end{array}$ & $\begin{array}{r}5,085 \\
312\end{array}$ \\
\hline $\begin{array}{l}\text { Ark. ........ } \\
\text { Cal......... }\end{array}$ & 5,011 & 1,461 & 302 & 8,892 & $\begin{array}{r}10,290 \\
2,075\end{array}$ & $\begin{array}{l}312 \\
378\end{array}$ \\
\hline Colo.......... & 15,128 & 2,497 & 130 & 21,582 & 1,068 & $\begin{array}{l}3.8 \\
395\end{array}$ \\
\hline Conn....... & 9,388 & 2,274 & 13 & 1,600 & 2,009 & 14 \\
\hline Del......... & 5,081 & 2,788 & 446 & 1,103 & 4,383 & 13 \\
\hline D. of C..... & 17,222 & 10,060 & 954 & $\ldots \ldots \ldots$ & 9,418 & 106 \\
\hline Fla........ & 17,215 & 981 & 315 & 2,853 & 10,639 & 1,002 \\
\hline Ga.......... & 3,408 & 483 & 788 & 1,274 & 5,397 & 321 \\
\hline Hawaii ..... & 3,943 & 497 & 304 & 3,912 & 309 & 25 \\
\hline Idaho ...... & 11,343 & 5,308 & 67 & 97,399 & 3,560 & 140 \\
\hline $111 . . . \ldots \ldots$ & 9,465 & 4,117 & 388 & 3,143 & 18,038 & 27 \\
\hline lnd......... & 7,791 & 3,477 & 314 & 8,058 & 17,407 & 21 \\
\hline Ind. Ter.... & 20,627 & 2,995 & 799 & 234 & 8,945 & 145 \\
\hline Iowa........ & 15,525 & 4,028 & 166 & 3,056 & 28,124 & 120 \\
\hline Kans. . & 10,780 & 2,351 & 294 & 629 & 8,628 & 44 \\
\hline $\mathrm{Ky}, \ldots \ldots \ldots$ & 4,928 & 2,055 & 891 & 5,903 & 8,893 & 54 \\
\hline La $\ldots . . . .$. & 6,061 & 1,758 & 1,308 & 1,988 & 7.129 & 346 \\
\hline Maine...... & 5,379 & 1,687 & 7 & 6,669 & 1,254 & 4 \\
\hline Md.......... & 5,660 & 2,882 & 340 & 3,696 & 6,149 & 23 \\
\hline Mass... & 9,086 & 2,384 & 11 & 1,670 & 2,508 & 40 \\
\hline Mieh... & 7,838 & 3,340 & 18 & 15,645 & 6,635 & 16 \\
\hline Minn... & 7,129 & 2,653 & 33 & 2,247 & 5,489 & 15 \\
\hline Miss ... & 4,788 & 1,257 & 1,185 & 1,714 & 7,075 & 304 \\
\hline Mo..... & 8,761 & 2,844 & 860 & 3,198 & 13,309 & 72 \\
\hline Iont... & 8,176 & 2,786 & 24 & 52,096 & 418 & 14 \\
\hline Neb.... & 10,619 & 2,659 & 186 & 1,709 & 13,801 & 8 \\
\hline Nev.... & 15,013 & 3,130 & 119 & 34,574 & 591 & 181 \\
\hline N. H. . & 6,283 & 1,520 & 4 & 2,912 & 1,419 & 6 \\
\hline N. J ........ & 8,447 & 3,310 & 174 & 1,680 & 6,173 & 25 \\
\hline N. Mex..... & 19,331 & 2,556 & 414 & 95,490 & 398 & 4,368 \\
\hline N. Y... & 11,464 & 2,775 & 16 & 7,708 & 2,988 & 6 \\
\hline N. C... & 2,745 & 700 & 600 & 1,327 & 5,717 & 189 \\
\hline N. Dak & 4,230 & 2,316 & 45 & 4,388 & 1,234 & 7 \\
\hline Ohio... & 8,380 & 3,584 & 69 & 16,409 & 13,013 & 22 \\
\hline Okla... & 10,877 & 1,932 & 364 & 454 & 3,721 & 24 \\
\hline Ore... & 6,953 & 2,859 & 77 & 30,188 & 2,794 & 1,089 \\
\hline
\end{tabular}


VIII. Number of Domestic ANimals-Concluded

\begin{tabular}{|c|c|c|c|c|c|c|}
\hline \multirow[b]{2}{*}{$\begin{array}{l}\text { States and } \\
\text { territories }\end{array}$} & \multicolumn{6}{|c|}{ Domestic animals } \\
\hline & $\underset{\text { cattle }}{\text { All neat }}$ & Horses & $\begin{array}{l}\text { Mules, } \\
\text { asses and } \\
\text { burros }\end{array}$ & Sheep & Swine & Goats \\
\hline Pa..... & 9,792 & 3,051 & 199 & 7,904 & 5,720 & 11 \\
\hline R. $1 \ldots$ & 7,909 & 2,500 & 9 & 2,460 & 2,526 & 5 \\
\hline S. C.... & 2,452 & 561 & 841 & 512 & 4,426 & 190 \\
\hline S. Dak. .... & 8,111 & 2,521 & 37 & 4,065 & 4,316 & 15 \\
\hline Tenn....... & 4,484 & 1,732 & 1,291 & 2,438 & 9,719 & 127 \\
\hline Texas ...... & 7,494 & 1,009 & 416 & 1,502 & 2,119 & 499 \\
\hline Utah. & 8,348 & 2,815 & 73 & 92,749 & 1,597 & 35 \\
\hline$V t \ldots$ & 10,624 & 1,810 & 8 & 6,277 & 2,013 & 2 \\
\hline Va.... & 4,147 & 1,500 & 240 & 3,481 & 4,754 & 27 \\
\hline Wash ...... & 4,647 & 2,871 & 34 & 10.941 & 2,136 & 34 \\
\hline W. Va...... & 6,005 & 1,738 & 108 & 9,093 & 4,156 & 8 \\
\hline Wis......... & 11,650 & 2,798 & 25 & 8,435 & 10,143 & 20 \\
\hline Wyo........ & 8,459 & 1,668 & 20 & 62,768 & 190 & 33 \\
\hline
\end{tabular}




\section{NUMBER OF NEAT CATTLE}

Number of neat cattle, June 1, 1900, on farms and ranges, and in barns and enclosures elsewhere, by states and territories

\begin{tabular}{|c|c|c|c|c|c|c|}
\hline \multirow{2}{*}{$\begin{array}{l}\text { States and } \\
\text { territories }\end{array}$} & \multicolumn{6}{|c|}{ Neat Cattlo } \\
\hline & $\begin{array}{c}\text { Total } \\
\text { number }\end{array}$ & $\begin{array}{l}\text { Calves } \\
\text { under } \\
1 \text { year }\end{array}$ & $\begin{array}{l}\text { Steers } \\
1 \text { year } \\
\text { and over }\end{array}$ & $\begin{array}{c}\text { Heifers } \\
1 \text { year and } \\
\text { under } 2\end{array}$ & $\begin{array}{c}\text { Dairy cows } \\
\text { 2 years } \\
\text { and over }\end{array}$ & $\begin{array}{l}\text { Other cows } \\
2 \text { years } \\
\text { and over }\end{array}$ \\
\hline Ala. & 849,470 & 225,856 & 138,799 & 85,945 & 302,129 & 78,147 \\
\hline Alaska & 18 & $\ldots \ldots \ldots$ & 4* & & 13 & \\
\hline Ariz......... & 744,873 & 135,503 & 138,110 & 73,564 & 18,638 & 358,607 \\
\hline Ark .......... & 940.275 & 267,341 & 137,841 & 106,787 & 334,128 & 80,547 \\
\hline Cal.... & $1,479,218$ & 333,908 & 338,263 & 149,656 & 326,756 & 305,434 \\
\hline Colo......... & $1,453,971$ & 271,779 & 407,610 & 153,190 & 108,697 & 486,086 \\
\hline Conn......... & 225,032 & 37,919 & 14,297 & 26,963 & 132,521 & 8,288 \\
\hline Del.... & 55,420 & 9,427 & 3,394 & 5,425 & 33,645 & 1,873 \\
\hline D. of C. & 2,077 & 85 & 9 & 104 & 1,809 & 47 \\
\hline Fla..... & 765,563 & 141,579 & 161,126 & 71,362 & 84,274 & 287,708 \\
\hline Ga.... & 937,377 & 200,043 & 133,508 & 95,658 & 296,962 & 165,970 \\
\hline Hawaii ..... & 102,908 & 17,517 & $38,152 \dagger$ & 9,433 & 4,028 & 32,948 \\
\hline Idaho. & 369,217 & 87,722 & 78,570 & 40,805 & 54,520 & 101,248 \\
\hline Ill..... & $3,219,044$ & 733,5042 & 792,221 & 335,936 & $1,064,491$ & 231,040 \\
\hline Ind.... & $1,737,097$ & 433,858 & 388,045 & 185,146 & 611,772 & 89,442 \\
\hline Ind. Ter.... & $1,519,2.59$ & 242,631 & 706,074 & 101,268 & 119,362 & 337.592 \\
\hline Iowa....... & $5,447,510$ & $1,299,294$ & $1,516,299$ & 595,389 & $1,479,6 \pi 6$ & 463,361 \\
\hline Kans. . & $4,552,642$ & 931,630 & $1,532,049$ & 450,366 & 714,196 & 861,508 \\
\hline Ky. ... & $1,119,739$ & 256,999 & 304,100 & 105,906 & 387,608 & 52,059 \\
\hline La..... & 699,631 & 177,205 & 119,632 & 68,069 & 197,264 & 126,301 \\
\hline Maine. & 354,470 & 63,316 & 38,844 & 47,056 & $185, \overline{5} 48$ & 12,629 \\
\hline Mld.... & 306,710 & 56,629 & 42,903 & 29,691 & 157,566 & 9,777 \\
\hline Mass. & 304,395 & 45,026 & 6,456 & 35,732 & 199,452 & 10,463 \\
\hline Mich... & $1,425,700$ & 381,921 & 212,258 & 163,497 & 601,844 & 46,603 \\
\hline Minn & $1,918,737$ & 571,983 & 231,880 & 213,340 & 789,683 & 69,095 \\
\hline Miss... & 911,375 & 248,536 & 149,060 & 92,500 & 316,217 & 86,975 \\
\hline Mo. .... & $3,062,859$ & 646,727 & 915,881 & 315,671 & 814,578 & 325,634 \\
\hline Mont. . & 974,845 & 188,834 & 312,654 & 98,253 & 48,317 & 312,193 \\
\hline Neb. ... & $3,220,242$ & 760,127 & 845,818 & 347,335 & 538,856 & 675,893 \\
\hline Ner.. & 386,249 & 81,257 & 83,579 & 45,015 & 14,178 & 153,514 \\
\hline N. H. . & 231,871 & 40,761 & 23,805 & 29,978 & 118,751 & 13,512 \\
\hline N. J... & 257.389 & 40,923 & 7,318 & 24,351 & 167,799 & 8,391 \\
\hline N. Mex. & 996,790 & 189,681 & 142,655 & 114,406 & 18,120 & 504,280 \\
\hline N. Y. . & $2,651,944$ & 513,103 & 77,003 & 338,980 & $1,537,921$ & 99,280 \\
\hline N. C... & 645,417 & 146,014 & 103,004 & 69,707 & 246,755 & 61,956 \\
\hline N. Dak. & 667,087 & 158,149 & 188,886 & 69,827 & 131,119 & 108,704 \\
\hline Ohio ... & $2,117,925$ & 500,751 & 400,102 & 220,178 & 868,832 & 88,440 \\
\hline
\end{tabular}

* Steers three years and over.

†Includes 80 Chinese buffaloes and 47 working bullocks. 


\section{The Farmer's Business Handbook}

IX. Number of Neat Cattle-Concluded

\begin{tabular}{|c|c|c|c|c|c|c|}
\hline \multirow{2}{*}{$\begin{array}{l}\text { States and } \\
\text { territories }\end{array}$} & \multicolumn{6}{|c|}{ Neat Cattle } \\
\hline & $\begin{array}{c}\text { Total } \\
\text { number }\end{array}$ & $\begin{array}{l}\text { Calves } \\
\text { under } \\
1 \text { year }\end{array}$ & $\begin{array}{l}\text { Steers } \\
1 \text { year } \\
\text { and over }\end{array}$ & $\begin{array}{l}\text { Heifers } \\
1 \text { year and } \\
\text { under } 2\end{array}$ & $\begin{array}{l}\text { Dairy cows } \\
2 \text { years } \\
\text { and over }\end{array}$ & $\begin{array}{l}\text { Other cows } \\
2 \text { years } \\
\text { and over }\end{array}$ \\
\hline Okla. & $1,716,749$ & 301,478 & 658,301 & 125,439 & 169,613 & 438,994 \\
\hline Ore... & 715,599 & 171,443 & 135,108 & 79,317 & 132,669 & 183,263 \\
\hline Pa..... & $1,997,192$ & 430,674 & 194,254 & 230,043 & $1,022,074$ & 50,207 \\
\hline R. I... & 37,677 & 5,444 & 1,034 & 3,942 & 25,027 & 1,396 \\
\hline S. C.. & 358,157 & 90,314 & 43,617 & 34,767 & 136,333 & 42,857 \\
\hline S. Dak. .... & $1,562,175$ & 345,767 & 473,774 & 168,331 & 280,024 & 270,962 \\
\hline Tenn. & 962,553 & 248,245 & 203,181 & 96,330 & 351,949 & 50,699 \\
\hline Texas. & $9,595,611$ & $2,192,008$ & $1,907,900$ & 963,838 & 924,899 & $3,403,625$ \\
\hline Utah. & 356,621 & 81,532 & 56,694 & 41,193 & 74,284 & 97,400 \\
\hline Vt.... & 510,341 & 102,416 & 24,922 & 69,313 & 276,592 & 21,852 \\
\hline Va. & 853,903 & 166,609 & 259,961 & 72,908 & 301,905 & 41,315 \\
\hline Wash. & 414,044 & 109,406 & 73,905 & 45,387 & 119,041 & 58,695 \\
\hline W. Va. & 655,544 & 136,504 & 195,628 & 60,840 & 217,538 & 36,909 \\
\hline Wis. . & $2,358,276$ & 628,554 & 292,116 & 287,289 & $1,032,811$ & 69,251 \\
\hline Wyo.... & 689,970 & 127,275 & 219,288 & 68,007 & 19,923 & 244,939 \\
\hline
\end{tabular}


X. NUMBER OF HORSES, ETC.

Number of horses, mules and asses, June 1, 1900, on farms and ranges, and in barns and enclosures elsewhere, by states and territories

\begin{tabular}{|c|c|c|c|c|c|c|}
\hline \multirow{2}{*}{$\begin{array}{l}\text { States and } \\
\text { territories }\end{array}$} & \multicolumn{3}{|c|}{ Horses } & \multicolumn{2}{|c|}{ Mules } & \multirow{2}{*}{$\begin{array}{c}\begin{array}{c}\text { Asses and } \\
\text { burros }\end{array} \\
\begin{array}{c}\text { Total } \\
\text { number } \\
\text { all ages }\end{array}\end{array}$} \\
\hline & $\begin{array}{l}\text { Total } \\
\text { number }\end{array}$ & $\begin{array}{l}\text { Colts } \\
\text { under } 2 \\
\text { years }\end{array}$ & $\begin{array}{c}\text { Two } \\
\text { sears and } \\
\text { over }\end{array}$ & $\begin{array}{l}\text { Total } \\
\text { number }\end{array}$ & $\begin{array}{l}\text { Two years } \\
\text { and over }\end{array}$ & \\
\hline Ala. & 171,318 & 17,131 & 154,187 & 199,432 & 186,671 & 2,019 \\
\hline Alaska & & & & & & \\
\hline Ariz........ & 131,453 & 41,540 & 89,913 & 4,808 & 3 , & 6,091 \\
\hline . & 279,100 & 32,141 & 246,959 & 182,384 & 162,398 & 2,733 \\
\hline Cal... & 515,464 & 49,039 & 466,425 & 88,252 & 76,601 & 2,787 \\
\hline Colo.. & 273,309 & 52,011 & 221,298 & 9,196 & 7,388 & 7,542 \\
\hline Conn.. & 93,235 & 2,059 & 91,176 & 325 & 277 & 42 \\
\hline Del.. & 36,424 & 3,551 & 32,8 & 5,042 & 4,646 & 19 \\
\hline D. of C..... & 12,453 & 98 & 12,355 & 357 & 357 & \\
\hline Fla.......... & 50,396 & 4,566 & 45,830 & 16,922 & 16,424 & 157 \\
\hline Ga... & 148,511 & 8,898 & 139,613 & 214,921 & 208,271 & 645 \\
\hline $\mathrm{Ha}$ & 12 & 1,9 & 11. & 6,506 & 6,013 & 1,438 \\
\hline 1daho... & 182,328 & 39,763 & 142,565 & 2,300 & 1,807 & 591 \\
\hline IIl... & $1,593,138$ & 228,325 & $1,364,813$ & 131,112 & 103,862 & 2,958 \\
\hline lnd.... & 879,944 & 110,489 & 769,455 & 71,140 & 56,476 & 1,234 \\
\hline Ter & 237,834 & 40,645 & 197,189 & 60,146 & 50 & 1,438 \\
\hline$\cdots$ & $1,547,348$ & 264,237 & $1,283,111$ & 60,985 & 47 & 2,335 \\
\hline Kans... & $1,072,651$ & 154,507 & 918,144 & 122,729 & 09 & 4,400 \\
\hline Kу..... & 497,245 & 52,601 & 444,644 & 198,110 & 156 & 5,638 \\
\hline 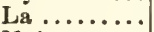 & 220,717 & 26,676 & 194, & 150,982 & 142,249 & 953 \\
\hline aine... & 140,3 & 7,110 & 133. & 403 & 281 & 66 \\
\hline .. & 18 & 19,460 & 16 & $19, \overline{7} 34$ & 18,121 & 141 \\
\hline .. & 208,653 & 3,457 & 205 & 788 & 698 & 106 \\
\hline ch. & 689,0 & 71,159 & 617 & 3,296 & 2,753 & 184 \\
\hline n... & 78 & & & 9,166 & 7,550 & 216 \\
\hline ss ... & 24 & 1 & 3 & 218,621 & 198,524 & 2,017 \\
\hline$\ldots$. & $1,096,550$ & 123,799 & 1 & 296,261 & 207,0 & 9,435 \\
\hline nt... & 347,247 & 85,913 & 26 & 3,090 & 2,0 & 145 \\
\hline b. ... & 863,939 & 142,646 & 721,2 & 57,924 & 44,494 & 1,040 \\
\hline$\ldots$ & 83,597 & 21,935 & 61,662 & 3,132 & 2,085 & 297 \\
\hline H. .. & 77,2 & 2,3 & & 127 & & 38 \\
\hline$\ldots$ & 177,215 & 5,142 & 172,0 & 6,011 & 5,610 & 121 \\
\hline N. Mex. & 140,878 & 34,249 & 106,6 & 5,948 & 4,725 & 17,469 \\
\hline N. Y.... & 934,375 & 52,108 & 882,267 & 5,179 & 4,784 & 759 \\
\hline N. C. . & 174,933 & 12,065 & & 138,786 & 129,995 & 917 \\
\hline Dak. & 376 & 61,5 & & 7,115 & 6,1 & 114 \\
\hline Obio ... & $1,068,170$ & 126,060 & 942,1 & 21,543 & 18,6 & 462 \\
\hline Okla. . & 319,319 & 55,919 & 263,400 & 57,416 & 44,178 & 1,650 \\
\hline Ore.... & 307,959 & 54,318 & 253,641 & 7,956 & 5,838 & 350 \\
\hline
\end{tabular}


X. Number of Horses, Etc.-Concluded

\begin{tabular}{|c|c|c|c|c|c|c|}
\hline \multirow{2}{*}{$\begin{array}{l}\text { States and } \\
\text { territories }\end{array}$} & \multicolumn{3}{|c|}{ Horses } & \multicolumn{2}{|c|}{ IIules } & \multirow{2}{*}{$\begin{array}{c}\begin{array}{c}\text { Asses and } \\
\text { burros }\end{array} \\
\begin{array}{c}\text { Total } \\
\text { number } \\
\text { all ages }\end{array}\end{array}$} \\
\hline & $\begin{array}{c}\text { Total } \\
\text { number }\end{array}$ & $\begin{array}{c}\text { Colts } \\
\text { under } 2 \\
\text { years }\end{array}$ & $\begin{array}{l}\text { Two } \\
\text { years and } \\
\text { over }\end{array}$ & $\begin{array}{c}\text { Total } \\
\text { number }\end{array}$ & $\begin{array}{l}\text { Two years } \\
\text { und over }\end{array}$ & \\
\hline $\mathrm{Pa}$. & 811,236 & 67,380 & 743,856 & 60,269 & 55,288 & 1,177 \\
\hline R. I.. & 31,370 & 328 & 31,042 & 47 & 45 & 6 \\
\hline S. C... & 88,274 & 6,066 & 82,208 & 120,201 & 116,527 & 301 \\
\hline S. Dak..... & 505,713 & 101,382 & 404,331 & 7,313 & 5,617 & 238 \\
\hline Tenn... & 391,604 & 48,404 & 343,200 & 264,248 & 210,321 & 9,395 \\
\hline Texas. & $1,393,863$ & 196,468 & $1,197,395$ & 526,651 & 451,971 & 18,855 \\
\hline Utah .. & 128,886 & 25,474 & 103,412 & 2,277 & 1,404 & 927 \\
\hline$v t . \ldots . .$. & 105,896 & 6,599 & 99,297 & 362 & 305 & 30 \\
\hline Va... & 326,616 & 40,352 & 286,264 & 50,576 & 43,374 & 621 \\
\hline Wash. & $266 i, 444$ & 53,438 & 213,006 & 3,097 & 2,321 & 183 \\
\hline W. Va.. & 203,285 & 25,232 & 178,053 & 14,849 & 13,217 & 174 \\
\hline Wis.... & 641,493 & 77,663 & 563,830 & 4,947 & 3,970 & 529 \\
\hline Wyo... & 144,914 & 36,816 & 108,098 & 2,047 & 1,586 & 466 \\
\hline
\end{tabular}




\section{NUMBER OF SHEEP, SWINE AND GOATS}

Number of sheep, swine and goats, June 1, 1900, on farms and ranges, and in barns and enclosures elsewhere, by states and territories

\begin{tabular}{|c|c|c|c|c|c|c|}
\hline \multirow{2}{*}{$\begin{array}{l}\text { States and } \\
\text { territories }\end{array}$} & \multicolumn{4}{|c|}{ Sheep } & \multirow{2}{*}{$\begin{array}{c}\text { Swine } \\
\text { Total } \\
\text { number } \\
\text { all ages }\end{array}$} & \multirow{2}{*}{$\frac{\text { Goats }}{\begin{array}{c}\text { Total } \\
\text { number } \\
\text { all ages }\end{array}}$} \\
\hline & $\begin{array}{c}\text { Total } \\
\text { number }\end{array}$ & $\begin{array}{l}\text { Lambs } \\
\text { under } \\
1 \text { year }\end{array}$ & $\begin{array}{c}\text { Ewes } \\
1 \text { year and } \\
\text { over }\end{array}$ & $\begin{array}{c}\text { Rams and } \\
\text { wethers } 1 \\
\text { yr.and over }\end{array}$ & & \\
\hline Ala. & 323,457 & 89,041 & 161,211 & 73,205 & $1,474,347$ & 122,175 \\
\hline Alask & $\ldots \ldots \ldots$ & & & & & \\
\hline Ariz. & 924,884 & 256,308 & 452,331 & 216,245 & 18,815 & 99,994 \\
\hline rk. & 259,595 & 89,030 & 132,079 & 38,486 & $1,766,317$ & 53,616 \\
\hline & $2,581,584$ & 842,900 & $1,346,103$ & 392,581 & 622,365 & 112,627 \\
\hline Colo & $2,045,577$ & 692,272 & $1,090,001$ & 263,304 & 104,245 & 41,379 \\
\hline Conn. & 37,136 & 14,024 & 20,745 & 2,367 & 51,337 & 550 \\
\hline Del... & 11,776 & 4,812 & 6,360 & 604 & $50,86^{\circ}$ & 205 \\
\hline . of C. & 30 & 14 & 15 & 1 & 1,134 & 73 \\
\hline B. & 125,406 & 21,979 & 56,231 & 47.196 & 479,899 & 45,053 \\
\hline & 040 & 78,531 & 165,217 & 98,292 & $1,464,455$ & 86,670 \\
\hline & 098 & 17,492 & 61,646 & 22,960 & 8,057 & 653 \\
\hline daho.. & $3,122,576$ & $1,156,522$ & $1,611,395$ & 354,659 & 117,547 & 4,500 \\
\hline 1 & 472 & 411,967 & 577,901 & & 6,0 & 11,861 \\
\hline ac & $1,748,311$ & 733523 & 944,077 & 70,711 & $3,840,784$ & 5,281 \\
\hline Ind. Ter & 17,343 & 4,510 & 8,386 & 4,447 & 674,209 & 10,949 \\
\hline lowa.... & $1,059,575$ & 399,830 & 577,668 & 82,077 & $9,851,929$ & 42,275 \\
\hline . & 264,045 & 82,874 & 134 & 59 & 3 , & 18,899 \\
\hline. & 1,30 & 582,178 & 56 & 68,798 & 2,00 & 12,603 \\
\hline &, 943 & 50,956 & 115,374 & 55,613 & 812,817 & 40,399 \\
\hline $\mathrm{Ma}$ & 427,209 & 169,948 & 37 & 24 & 663 & 315 \\
\hline . & 194, & 80,208 & 10 & 29 & 12 & 1,563 \\
\hline 8 & & 19,307 & & 85 & & 1,747 \\
\hline & $2,753,083$ & $1,123,441$ & $1,511,712$ & 117,930 & 1,1 & 3,464 \\
\hline $\mathrm{Ml}$ & 594,006 & 231,746 & 332,722 & 29,538 & 3,651 & 4,109 \\
\hline Mlss... & 751 & 76,921 & 163,786 & 75,044 & & 57,283 \\
\hline Io & $1,095,920$ & 424,315 & & 38 & 4,6 & 25,475 \\
\hline Mo & $6,170,580$ & $1.955,295$ & 2,95 & 1,219 & 29 & 1,723 \\
\hline Neb. . & 517,299 & 456 & 284,474 & 69 & $4,221,094$ & 2,783 \\
\hline $\mathrm{Ne}$ & 887,110 & 318,806 & 434,591 & 133,713 & & 4,652 \\
\hline N. H. & 105,702 & 40,049 & 61,620 & 4,033 & & 253 \\
\hline T & & 21,496 & & 2,383 & 201,341 & 2,449 \\
\hline ex & $4,902,547$ & $1,566,750$ & $2,852,657$ & 483,140 & 21,866 & 236,352 \\
\hline N. Y... & $1,763,794$ & 765,262 & 950,645 & 47,887 & 728,815 & 4,362 \\
\hline N. C. & 303,063 & 93,416 & 164,721 & 44,926 & $1,340,478$ & 44,025 \\
\hline N. Dak. & 682,391 & 230,658 & 340,497 & 111,236 & & 1,180 \\
\hline & $4,030,021$ & $1,374,630$ & $2,094,420$ & 560,971 & 3,285 & 6,581 \\
\hline Okla... & 71,3 & 22,837 & 37 & $10, \mathrm{C}$ & 59 & 3.877 \\
\hline Ore.... & $3,042,767$ & $1,079,559$ & $1,481,172$ & 482,036 & 286,541 & 109,995 \\
\hline
\end{tabular}


XI. Number of Sheep, Swine and Goats - Concluded

\begin{tabular}{|c|c|c|c|c|c|c|}
\hline \multirow{2}{*}{$\begin{array}{l}\text { States and } \\
\text { territories }\end{array}$} & \multicolumn{4}{|c|}{ Sheep } & \multirow{2}{*}{$\begin{array}{c}\text { Swine } \\
\begin{array}{c}\text { Total } \\
\text { number } \\
\text { all ages }\end{array}\end{array}$} & \multirow{2}{*}{$\begin{array}{c}\text { Goats } \\
\begin{array}{c}\text { Total } \\
\text { nnmber } \\
\text { all ages }\end{array}\end{array}$} \\
\hline & $\begin{array}{c}\text { Total } \\
\text { number }\end{array}$ & $\begin{array}{l}\text { Lambs } \\
\text { under } \\
1 \text { year }\end{array}$ & $\begin{array}{l}\text { Eweg } \\
1 \text { year and } \\
\text { over }\end{array}$ & $\begin{array}{c}\text { Rams and } \\
\text { wethers 1 } \\
\text { yr.and over }\end{array}$ & & \\
\hline Pa... & $1,541,133$ & 574,043 & 776,252 & 190,838 & $1,265,327$ & 8,745 \\
\hline R. I. & 11,285 & 4,612 & 5,940 & 733 & 12,868 & 98 \\
\hline S. C... & 72,060 & 19,215 & 40,695 & 12,150 & 631,025 & 27,257 \\
\hline S. Dak.. & 775,664 & 268,145 & 422,211 & 85,308 & 832,253 & 2,969 \\
\hline Tenn... & 499,277 & 189,456 & 257,602 & 52,219 & $2,059,896$ & 27,341 \\
\hline Texas. & $1,898,794$ & 451,361 & 931,161 & 516,272 & $2,778,881$ & 640,710 \\
\hline Utah. & $3,821,838$ & $1,265,802$ & $1,896,311$ & 659,725 & 71,768 & 1,469 \\
\hline Vt...... & 297,521 & 114,738 & 168,866 & 13,917 & 100,510 & 151 \\
\hline Va..... & 695,614 & 301,732 & 354,985 & 38,897 & 999,272 & 6,315 \\
\hline Wash.. & 930,988 & 372,199 & 459,755 & 99,034 & 187,104 & $\mathbf{3}, 008$ \\
\hline W. Va. & 970,679 & 396,855 & 498,242 & 75,582 & 465,029 & 1,519 \\
\hline Wis... & $1,679,248$ & 690,449 & 920,839 & 67,960 & $2,042,094$ & 5,404 \\
\hline Wyo.... & $5,099,765$ & $1,772,469$ & $2,498,990$ & 828,306 & 15,610 & 2,669 \\
\hline
\end{tabular}


XII. NUMBER AND VALUE OF NEAT CATTLE

Number and value of neat cattle on farms and ranges, June 1, 1900, by states and Ter.

\begin{tabular}{|c|c|c|c|c|c|c|}
\hline \multirow{3}{*}{$\begin{array}{l}\text { States and } \\
\text { territories }\end{array}$} & \multirow{3}{*}{$\begin{array}{c}\begin{array}{c}\text { Domestic } \\
\text { animals }\end{array} \\
\text { Total } \\
\text { value }\end{array}$} & \multicolumn{5}{|c|}{ Neat cattle } \\
\hline & & \multirow{2}{*}{$\begin{array}{c}\text { Total } \\
\text { number }\end{array}$} & \multirow{2}{*}{$\begin{array}{l}\text { Tota! } \\
\text { value }\end{array}$} & \multirow{2}{*}{$\begin{array}{l}\begin{array}{l}\text { Calves un } \\
\text { der } 1 \text { jear }\end{array} \\
\frac{\text { Value }}{}\end{array}$} & \multicolumn{2}{|c|}{$\begin{array}{c}\text { Steors } 1 \text { yenr and } \\
\text { under } 2\end{array}$} \\
\hline & & & & & Number & Value \\
\hline Ald & $\$ 34,408,932$ & 799,734 & $\$ 9,793,556$ & $\$ 826,805$ & 52,023 & $\$ 355,759$ \\
\hline $\begin{array}{l}\text { Alas } \\
\text { Ariz }\end{array}$ & $\begin{array}{r}1,880 \\
15,375,286\end{array}$ & $\begin{array}{r}18 \\
742,635\end{array}$ & $\begin{array}{r}1,315 \\
11,367,466\end{array}$ & $\cdots, 133,178$ & 65,203 & \\
\hline Ar & $\begin{array}{l}10,35,739,425 \\
\end{array}$ & 894,535 & $11,885,627$ & $1,418,961$ & 82,062 & $\begin{array}{l}898,604 \\
79 \cap, 393\end{array}$ \\
\hline$\cdots$ & $65,000,738$ & $1,444,624$ & $32,655,146$ & $2,796,201$ & 134,962 & $2,296,430$ \\
\hline $\mathrm{Co}$ & $49,359,781$ & $1,433,318$ & $35,532,738$ & $3,130,465$ & 204,101 & $4,130,902$ \\
\hline Co & $10,247,634$ & 217,058 & $5,944,265$ & $29.3,317$ & 3.356 & 59,630 \\
\hline De & $3,733,335$ & 54,180 & $1,340,885$ & 83,940 & 1,042 & 15,446 \\
\hline D. & 122,019 & 1,462 & 54,471 & 605 & 5 & $\begin{array}{r}10,75 \\
75\end{array}$ \\
\hline Fis & $10,687,632$ & 751,261 & $6,344,349$ & 586,919 & 67,292 & 405.590 \\
\hline & $33,499,683$ & 899,491 & $8,828,498$ & 770,968 & 62,128 & 343,053 \\
\hline & $2,523,479$ & 102,908 & $1,293,766$ & 85.654 & 15,075 & 140,301 \\
\hline Ida & $21,389.853$ & 363,534 & $8,389,954$ & 883,908 & 39,646 & 781,993 \\
\hline Iil. . & $186,856,020$ & $3,104,010$ & $82,170,907$ & $7,195,897$ & 364,103 & $8,251,444$ \\
\hline Ind & $105,048,528$ & $1,684,478$ & $40,964,524$ & $4,197,697$ & 205,515 & $4,394,549$ \\
\hline Ind. Ter & $40,824,886$ & $1,499,364$ & $29,638,671$ & $2,094,135$ & 155,398 & $2,249,419$ \\
\hline Iоพ8... & $271,841,034$ & $5,367,630$ & $142,518,902$ & $14,413,585$ & 730,681 & $17,655,451$ \\
\hline $\mathrm{Kan}$ & $186,317,248$ & $4,491,078$ & $117,640,801$ & $10,630,929$ & 560,377 & $12,833,686$ \\
\hline Ky. & $70,488,187$ & $1,083,248$ & $24,987,741$ & $2,480,227$ & 141,943 & $2,851,193$ \\
\hline La & $27,757,301$ & 670,295 & $8,580,996$ & 817,872 & 57,344 & 470,339 \\
\hline Mai & $16,298,422$ & 338,847 & $7.585,545$ & 411,104 & 15,508 & 218,758 \\
\hline Id..... & $19,636,844$ & 292,646 & $6,853,121$ & 453,971 & 13,693 & 219,247 \\
\hline Ma & $14,730,169$ & 285,944 & $8,130,917$ & 357,542 & 2,476 & 38,893 \\
\hline $\mathrm{Mi}$ & $75,997,051$ & $1,376,408$ & $28,165,256$ & $2,490,467$ & $15 \overline{5}, 933$ & $2,510,554$ \\
\hline Minn. & $86,620,643$ & $1,871,325$ & $36,248,958$ & $4,254,414$ & 161.645 & $2,553,015$ \\
\hline $\mathrm{Mi}$ & $40,843,300$ & 873,356 & $12,070,921$ & $1.157,630$ & 63,962 & 525,015 \\
\hline & $154,295,363$ & $2,978,589$ & $75,656,807$ & $6,9 \pm 3,267$ & 386,809 & $8,713,53$ \\
\hline M & $51,724,113$ & 968,387 & $25,362,016$ & $2,229,419$ & 113,179 & $2,396,473$ \\
\hline & $142,769,629$ & $3,176,243$ & $82,469,498$ & $8,757,661$ & 401,158 & $9,303,685$ \\
\hline & $12,093,608$ & 385,192 & $8,273,260$ & 851,851 & 41,103 & 796,399 \\
\hline N. $\mathrm{H}$. & $10,062,877$ & 226.792 & $5,546,630$ & 305,895 & 9,028 & 139,302 \\
\hline & $16,269,548$ & 239.984 & $7,199,107$ & 349,937 & 1,519 & 25,951 \\
\hline N. & $31,644,179$ & 991,859 & $17,977,931$ & $1,989,648$ & 89,367 & $1,492,875$ \\
\hline N. Y... & $120,673,101$ & $2,596,389$ & $62,735,174$ & $3,144,954$ & 36,446 & 578,624 \\
\hline & $28,242,147$ & 624.518 & $7,667,950$ & 549,844 & 43,828 & $363.65 \%$ \\
\hline & $41,951,659$ & 657,434 & $15.810,637$ & $1,540,116$ & 92,234 & $1,866,101$ \\
\hline & $120,466,134$ & $2,053,3] 3$ & $46,560,246$ & $4,186,575$ & 223,946 & $4,300,265$ \\
\hline & $53,921,827$ & $1,709,752$ & $37,783,115$ & $3,208,409$ & 159,651 & $2,961,890$ \\
\hline & $33,172,342$ & 700,303 & $15,[64,897$ & $1,536,473$ & 68,754 & $1,253,752$ \\
\hline & $97,424,119$ & $3,896,847$ & $43,063,191$ & $3,032,067$ & 108,681 & $1,739,459$ \\
\hline & $2,281,817$ & 36,034 & $1,165,797$ & 45,537 & 149 & 2,604 \\
\hline & $19,167.220$ & 342.898 & $4,334,714$ & 361.454 & 14,975 & 95,827 \\
\hline S. Dak. & $64,287,578$ & 47,402 & $1,546,800$ & $3,782,871$ & 215,384 & $4,616,681$ \\
\hline Tenn.. & $58,043,895$ & 185,311 & 912,183 & $1,606,949$ & 110,368 & $1,432,680$ \\
\hline Texas.. & $236,227,934$ & 273,332 & $0,428,196$ & $19,528,804$ & 957,163 & $14,007,199$ \\
\hline$\overline{D t a h} \ldots$ & $21,175,867$ & 17,185 & 343,690 & 729,551 & 32,505 & 544,550 \\
\hline Vt..... & $17,373,169$ & 30,340 & 501.940 & 566,130 & 11,266 & 151,763 \\
\hline & $39,831,552$ & 134,861 & 825.512 & $1,273,728$ & 91,579 & $1,541,0,4$ \\
\hline $\mathbf{W}$ & $21,437.528$ & 27,481 & 394,823 & 889,058 & 39,340 & 698,051 \\
\hline Va. & $29,231,832$ & 83,235 & 639,782 & $1,102,228$ & 79,972 & $1,425,903$ \\
\hline Wis... & $93,521,430$ & 158,362 & $2,314,105$ & $4,107,904$ & 205.798 & $3,228,364$ \\
\hline 19000 & $39,080,158$ & 4,677 & $=-687,384$ & $-1,788,934$ & 78,513 & $-1,826,112$ \\
\hline
\end{tabular}




\section{The Farmer's Business Handbook}

XiI. Number and Value of Neat Cattle - Concluded

\begin{tabular}{|c|c|c|c|c|c|c|}
\hline \multirow{3}{*}{$\begin{array}{l}\text { Sta tes and } \\
\text { territories }\end{array}$} & \multicolumn{6}{|c|}{ Neat cattle - continued } \\
\hline & \multicolumn{2}{|c|}{$\begin{array}{c}\text { Steers } 2 \text { years and } \\
\text { over }\end{array}$} & \multicolumn{2}{|c|}{$\begin{array}{c}\text { Heifers } 1 \text { year and } \\
\text { under } 2\end{array}$} & \multirow{2}{*}{$\frac{\begin{array}{c}\text { Dairy cowg } \\
2 \text { years and } \\
\text { over }\end{array}}{\text { Number }}$} & \multirow{2}{*}{$\begin{array}{c}\text { Other cows } \\
2 \text { Jears and } \\
\text { over }\end{array}$} \\
\hline & Number & Value & Number & Value & & \\
\hline Ala & 77,437 & $\$ 1,192,321$ & 83,027 & $\$ 703,459$ & 279,263 & 76,560 \\
\hline Alaskik..... & & 450 & & & 13 & \\
\hline Ariz........ & 72.693 & $1,410,798$ & 73.437 & 961,818 & 17,965 & 357,719 \\
\hline Ark. & 49,194 & 745,573 & 103,555 & $1,064,074$ & 312,577 & $79,55 \%$ \\
\hline Cal. & $19 ., 523$ & $5,518,819$ & 148,289 & $2,696,263$ & 307,245 & 304,450 \\
\hline Colo & 198,844 & $6,047,864$ & 151,627 & $3,156,858$ & 100,116 & 483,039 \\
\hline Conn & 10,473 & 536,572 & 26,476 & 461.570 & 126,434 & 7,994 \\
\hline Del. & 2,291 & 68,549 & 5,373 & 91,933 & 32,591 & 1,866 \\
\hline D. of & 11 & 25 & 76 & 1,357 & 1,251 & 38 \\
\hline $\begin{array}{l}\text { Fla. } \\
\text { Ga. }\end{array}$ & 91,247 & 960,613 & 70,445 & 458,458 & 78,830 & 285,712 \\
\hline $\begin{array}{l}\text { Ga. } \\
\text { Haw }\end{array}$ & $\begin{array}{l}67,354 \\
23,077\end{array}$ & 675,949 & 93,585 & 680.407 & 276,024 & 164,052 \\
\hline $\begin{array}{l}\text { Hawa } \\
\text { Idaho }\end{array}$ & 23,077 & 353,714 & 9,433 & 98,621 & 4,028 & 32,948 \\
\hline $\begin{array}{l}\text { Idaho } \\
\text { Ill... }\end{array}$ & $\begin{array}{r}38,248 \\
387\end{array}$ & $1,161,747$ & 40,398 & 762,889 & 51,929 & 100,606 \\
\hline Ill... & 387,786 & $16,186,027$ & 332,472 & $6,735,360$ & $1,007,664$ & 228,931 \\
\hline Ind . & 176,038 & $6,531,225$ & 183,193 & $3,660,138$ & 574,276 & 88.619 \\
\hline Ind. Ter.... & 548,811 & $13,775,958$ & 99,734 & $1,398,859$ & 110,687 & 336,441 \\
\hline Iowa. & 776,761 & $33,134,999$ & 592,076 & $12,242,609$ & 423,648 & 461,031 \\
\hline Kan.. & 961,094 & $34,916,756$ & 447,295 & $0,112,935$ & 676,456 & 859,925 \\
\hline $\mathbf{K y} \ldots$ & 157,235 & $5,466,922$ & 104,861 & $1,880,432$ & 364,025 & 51,745 \\
\hline La... & 56,683 & 929,717 & 66,076 & 620,250 & 184,815 & 124,769 \\
\hline$M$ & 22,588 & 849,280 & 45,877 & $621,3 \overline{7} 4$ & 173,592 & 12,483 \\
\hline Md.. & 27,757 & 879,609 & 28,930 & 495,742 & 147,284 & 9,490 \\
\hline$\cdots$ & 3,678 & 152,815 & 34,452 & 587,080 & 184.562 & 9,946 \\
\hline$\cdots$ & 54,303 & $1,451,470$ & 161,174 & $2,685,813$ & 563,905 & 46.205 \\
\hline$\cdots$ & 67,778 & $1,736,446$ & 211,162 & $3,299,865$ & 753,632 & 68,565 \\
\hline$\cdots$ & 78,260 & $1,444,799$ & 89,985 & 899,800 & 299,318 & 85,629 \\
\hline$\cdots$ & 512,740 & $19,270,685$ & 312,749 & $6.040,589$ & 765,386 & 324,198 \\
\hline Mont.. & 198,671 & $6,790,791$ & 97.899 & $2,002,199$ & 45,036 & 311,513 \\
\hline Neb... & 436,950 & $16,682,057$ & 345,275 & $7,413,817$ & 512,544 & 674,025 \\
\hline Ner... & 42,371 & $1,235,984$ & 44,967 & 792,272 & 13,606 & 153,388 \\
\hline N. H. & 14,568 & 591,533 & 29,574 & 462,468 & 115,036 & 13,102 \\
\hline N. J... & 1,516 & 51,147 & 23,609 & 470,484 & 157,407 & 7,977 \\
\hline N. Mlex, & 52,513 & $1,267,888$ & 114,045 & $1,766,334$ & 16,775 & 502,865 \\
\hline N. Y... & 21,745 & $1,041,607$ & 335.844 & $5,151,703$ & $1,501,608$ & 98,466 \\
\hline & 57,271 & 902,188 & 68,732 & 561,321 & 233,178 & 61,082 \\
\hline N. Dak..... & 95,451 & $3,044,436$ & 69,338 & $1,379,518$ & 125,503 & 108,146 \\
\hline Ohio & 172,657 & $6,814,845$ & 217.571 & $3,959,411$ & 818,239 & 87,040 \\
\hline Okla. & 408,015 & $13,442,851$ & 125,029 & $2,262,978$ & 165,852 & 438,257 \\
\hline Ore. & 65,376 & $1,867,350$ & 78,628 &, 105 & 122,447 & 183,100 \\
\hline $\mathrm{Pa} . .$. & 80,634 & $2,616,109$ & 224,623 & $3,705,397$ & 943,773 & 48,807 \\
\hline R. I... & 862 & 45,681 & 3,815 & 73,276 & 23,660 & 1,379 \\
\hline S. C.... & 27,275 & 390.251 & 33,879 & 291,705 & 126,684 & 42,235 \\
\hline Dak. & 256,501 & $8,668,811$ & 167,607 & $3,347,421$ & 270,634 & 270,285 \\
\hline Tenn... & 88,428 & $1,727,003$ & 94,224 & $1,243,158$ & 321,676 & 49,560 \\
\hline Texas. & 934,889 & $21,379,269$ & 954,835 & $13,473,384$ & 861,023 & $3,369,880$ \\
\hline Utah. & 23,585 & 588.166 & 40,461 & 681,040 & 65,905 & 96,849 \\
\hline & 13,306 & 447,314 & 68,664 & 889,081 & 270,194 & 21,715 \\
\hline & 166,229 & $5,249,606$ & 71,952 & $1,029,057$ & 281,876 & 40,735 \\
\hline $\mathbf{W}$ & 33,224 & 979,101 & 44,113 & 805,325 & 107.232 & 58,395 \\
\hline W & 114,868 & $3,704,757$ & 60,268 & 990,655 & 205,601 & 36,870 \\
\hline W & 84,092 & $2,330,188$ & 285,319 & $4,526,586$ & 998,397 & 69,094 \\
\hline Wyo.. & 140,449 & $4,848,696$ & 67,888 & $1,549,469$ & 18,272 & 244,859 \\
\hline
\end{tabular}




\section{NUMBER AND VALUE OF SHEEP AND SWINE}

Number and value of sheep, swine and goats on farms and ranges, June 1, 1900, by states and territories.

\begin{tabular}{|c|c|c|c|c|c|c|}
\hline \multirow{2}{*}{$\begin{array}{l}\text { States and } \\
\text { Territories }\end{array}$} & \multicolumn{2}{|c|}{ Sheep } & \multicolumn{2}{|c|}{ Swine, all ages } & \multirow{2}{*}{$\begin{array}{c}\text { Received, } \\
1899 \text {, from } \\
\text { sale of live } \\
\text { animals }\end{array}$} & \multirow{2}{*}{$\begin{array}{c}\text { Value of } \\
\text { animals } \\
\text { slaughtered } \\
\text { on farms } \\
\text { in } 1890 \\
\text { Value }\end{array}$} \\
\hline & $\begin{array}{c}\text { Total } \\
\text { Number }\end{array}$ & $\begin{array}{l}\text { Total } \\
\text { Value }\end{array}$ & Number & Value & & \\
\hline & 53 & $\$ 4$ & 329 & 7,250 & 3,640 & $\$$ \\
\hline la & & & 10 & & 310 & \\
\hline ri & 61 & 1,9 & 103 & 0.587 & 3,745 & 13 \\
\hline . & & .318 & $1,713,307$ & 2,981 , & 43 & 481 \\
\hline & $2, \overline{6} 6$ &, 231 & 336 & 2476 . &, 165 & .820 \\
\hline Col & 2,044 & 5,5 & & 482, & $8,477,587$ & $1,093,365$ \\
\hline Con & 37 & 7,420 & & & $1,169,235$ & 845,123 \\
\hline Del & 5 & 8 & & & 6,264 & 424,400 \\
\hline D. & $\because$ & & 802 & 4,097 & 475 & 2,440 \\
\hline$\cdots$ & & & 464,277 & & .657 & 648 \\
\hline & & & $1,424,298$ & 2,577 &, 615 & 2,046 \\
\hline $\mathrm{Ha}$ & & & & & 3,476 & 64,081 \\
\hline da & 3,1 & 8,2 & 30 & & & \\
\hline$\cdots$ & 31 & & 68 & 23,6 & 993 & 10 \\
\hline & 02 & 5,7 & 3,76 & 13,8 &, 661 & 595 \\
\hline Ind & 05 & & , 255 & & 707 & 139 \\
\hline 1 & 1,05 & 3,9 & & & & \\
\hline 9 & & & & & & \\
\hline 8 & 1,29 & 4,1 & & & & \\
\hline & & & & &, 869 &, 437 \\
\hline & & 1,1 & & & ,717 & ,594 \\
\hline & & & & & 60 & \\
\hline & & & & & 54 & 11 \\
\hline is & 2,74 & 7 , & & & 18 & 786 \\
\hline & & & & & 16 &, 051 \\
\hline & & & & & & \\
\hline & 1,08 & & 64 & 16 , & 54 & 9, \\
\hline & 6,17 & 18 & 6 & & & \\
\hline if & 511,273 & 1 & 4,12 & 18,66 & 49 & - $4.508,457$ \\
\hline & & & & &, 221 & 270,228 \\
\hline N. & 105, & & & & ,941 & 794,342 \\
\hline & & & & & & 1,4 \\
\hline & 4,89 & 10,6 & & & & 996 \\
\hline & $1,745,74$ & $1,9+1$ & & 3,7 & $15,025,932$ & $8,319,750$ \\
\hline & 301,941 & 477,421 & $1,300,469$ & $2,516,410$ & & $7,109,655$ \\
\hline & & & & & & $1,573.588$ \\
\hline & 4,020 & 10,9 & 3,1 & 11,8 & & 10,2 \\
\hline & & & & & & $2,925,846$ \\
\hline & $3,040,291$ & $7,563,447$ & 281,406 & $1,057,037$ & & .895 \\
\hline
\end{tabular}


XiII. Number and Value of Sheep and Swine--Concluded

\begin{tabular}{|c|c|c|c|c|c|c|}
\hline \multirow{2}{*}{$\begin{array}{l}\text { States and } \\
\text { Territories }\end{array}$} & \multicolumn{2}{|c|}{ Sheep } & \multicolumn{2}{|c|}{ Swine, all ages } & \multirow{2}{*}{$\begin{array}{c}\begin{array}{c}\text { Received, } \\
1899 \text {, from } \\
\text { sale of live } \\
\text { animals }\end{array} \\
\text { Amount }\end{array}$} & \multirow{2}{*}{$\begin{array}{c}\begin{array}{c}\text { Value of } \\
\text { animals } \\
\text { slaughtered } \\
\text { on farms } \\
\text { in } 1899\end{array} \\
\text { Value }\end{array}$} \\
\hline & $\begin{array}{c}\text { Total } \\
\text { Number }\end{array}$ & Value & Number & Value & & \\
\hline & 631,066 & 642 & $1,107,981$ & $\$ 5,830,295$ & $\$ 15,4$ & $\$ 11,62$ \\
\hline & 11,207 & 41,282 & 11,508 & 90,614 & 157,478 & 142,824 \\
\hline C & $7], 538$ & 111,770 & 618,995 & $1,411,516$ & 823,554 & $2,730,076$ \\
\hline S. Dal & 775,236 & 434. & 823,1 & $3,540,072$ & $12,707,831$ & $1,567,049$ \\
\hline & 11 & & 1,976 & & 11, & 8, \\
\hline & $1,889,298$ &, 117 & $2,665,6$ & 7,60 & $34,357,265$ & $11,032,6$ \\
\hline Utah. & $3,818,423$ & $10,256,488$ & 65,732 & 293,115 & $2,695,504$ & 659,369 \\
\hline vt.... & 296,576 & 881,402 & 95,090 & 620,169 & $2,786,137$ & $1,347,754$ \\
\hline & 692,929 & $07 \approx 0$ & 946,4 & $2,572,524$ & $7,800,124$ & $5,859,5$ \\
\hline & 929,873 & 0,929 & 181 & 830 & $3,517,053$ & $1,168,802$ \\
\hline C & 968,843 & 1,556 & 442,844 & $1,389,808$ & $6,533,034$ & $2,895,032$ \\
\hline & $1,675,453$ & $4,510,356$ & $2,014,631$ & $7,580,423$ & $27,131,916$ & $5,407,114$ \\
\hline Wyo... & $5,099,613$ & $16,310,096$ & 15,471 & 78,145 & $3,673,124$ & 394,635 \\
\hline
\end{tabular}


XIV. AVERAgE VALUE OF NEAT CATtLE

Average value of neat cattle, on farms and ranges, June 1, 1900, by states and territories

\begin{tabular}{|c|c|c|c|c|c|c|}
\hline \multirow{2}{*}{$\begin{array}{l}\text { States and } \\
\text { terlitories }\end{array}$} & \multicolumn{6}{|c|}{ Neat cattle } \\
\hline & All cattle & $\begin{array}{l}\text { Calves un- } \\
\text { der } 1 \text { year }\end{array}$ & $\begin{array}{l}\text { Steers } 1 \\
\text { year and } \\
\text { over }\end{array}$ & $\begin{array}{l}\text { Heifers I } \\
\text { year and } \\
\text { under? }\end{array}$ & $\begin{array}{c}\text { Dairy cows } \\
2 \text { years and } \\
\text { over }\end{array}$ & $\begin{array}{c}\text { Other cows } \\
2 \text { years and } \\
\text { over }\end{array}$ \\
\hline Ala......... & $\$ 1225$ & $\$ 387$ & $\$ 1239$ & $\$ 847$ & $\$ 1974$ & $\$ 1302$ \\
\hline Alaska..... & 7306 & $\ldots . . . \ldots$ & 11250 & & 6231 & \\
\hline Ariz........ & 1531 & 838 & 1775 & 1310 & 3216 & 1650 \\
\hline Ark........ & 1329 & 558 & 1447 & 1028 & 2031 & 1615 \\
\hline Cal......... & 2260 & 849 & 2478 & 1818 & 3495 & 2550 \\
\hline Colo......... & 2479 & 1163 & 2771 & 2082 & 3794 & 2859 \\
\hline Conn....... & 2739 & 786 & $36 \quad 19$ & 1743 & 3371 & 2626 \\
\hline Del......... & 2475 & 897 & 2433 & 1711 & 3050 & 2493 \\
\hline D. of C.... & 3726 & 877 & +2000 & 1786 & 4029 & 2500 \\
\hline Fla ........ & 844 & 424 & 906 & 651 & 1331 & 940 \\
\hline Ga......... & 981 & 364 & 866 & 727 & 1681 & 896 \\
\hline Hawaii..... & 1257 & 489 & 1310 & 1045 & 3173 & 1389 \\
\hline Idaho ....... & 2308 & 1023 & 2770 & 1888 & 3461 & 2749 \\
\hline Ill......... & 2647 & 995 & 3785 & 2026 & 3402 & 3162 \\
\hline lnd $\ldots . . . \ldots$ & 2432 & 981 & 3451 & 1998 & 3184 & 3134 \\
\hline Ind. Ter.... & 1977 & 887 & 2098 & 1403 & 2397 & 2081 \\
\hline lowa....... & 2655 & 1117 & 3942 & 2068 & 3256 & 3105 \\
\hline Kaus. . . . . . & 2619 & 1151 & 3212 & 2037 & 3280 & 2892 \\
\hline Ky..... & 2307 & 990 & 3139 & 1793 & $28 \quad 89$ & 2627 \\
\hline La $\ldots \ldots \ldots$ & 1280 & 482 & 1389 & 939 & 1952 & 1546 \\
\hline Maine.. & 2239 & 665 & 2998 & 1354 & 2915 & 2179 \\
\hline Mll..... & $23 \quad 42$ & 818 & 2650 & 1714 & 2947 & 2302 \\
\hline Mass....... & 2844 & 820 & 3242 & 1704 & 3547 & 2635 \\
\hline Mich. . & 2046 & 663 & 2564 & 1666 & 3065 & 2593 \\
\hline Minn... & 1937 & 752 & 2477 & 1563 & 2855 & 2464 \\
\hline Miss ... & 1382 & 485 & 1461 & 1000 & 2141 & 1573 \\
\hline Mo..... & 2540 & 1096 & $34 \quad 18$ & 1931 & 3072 & 2854 \\
\hline Mont... & 2619 & 1189 & 3032 & 2045 & 4189 & 2976 \\
\hline Neb.... & 2596 & 1161 & 3513 & 2147 & 3354 & 3049 \\
\hline Nev.... & 2148 & 1051 & 2673 & 1762 & 3401 & 2445 \\
\hline N. H.. & 2446 & 757 & 3183 & 1564 & 3143 & 2435 \\
\hline N. J... & 3000 & 882 & 2901 & 1993 & 3710 & 2948 \\
\hline N. Mex. & 1813 & 1054 & 2217 & 1549 & 3041 & 1960 \\
\hline N. Y... & 2416 & 620 & 3017 & 1534 & 3243 & 2431 \\
\hline N. C... & 1228 & 385 & 1312 & 817 & 1898 & 1106 \\
\hline N. Dak..... & 2405 & 985 & 2931 & 1990 & 3250 & 3167 \\
\hline Ohio.... & 2268 & 846 & 3177 & 1820 & 3022 & 2697 \\
\hline
\end{tabular}

* Average value of steers over 3 years.

tAverage value of steers over one year and under 3 years.

$\mathbf{R}$ 
274 The Farmer's Business Handbook

Xiv. Average Value of Neat Cattle-Concluded

\begin{tabular}{|c|c|c|c|c|c|c|}
\hline \multirow[b]{2}{*}{$\begin{array}{l}\text { States and } \\
\text { territories }\end{array}$} & \multicolumn{6}{|c|}{ Neat cattle } \\
\hline & All cattle & $\begin{array}{l}\text { Calves un- } \\
\text { der } 1 \text { year }\end{array}$ & $\begin{array}{c}\text { Steers } 1 \\
\text { year and } \\
\text { over }\end{array}$ & $\begin{array}{l}\text { Heifers 1 } \\
\text { year and } \\
\text { under } 2\end{array}$ & $\begin{array}{l}\text { Dairy cows } \\
2 \text { years and } \\
\text { over }\end{array}$ & $\begin{array}{l}\text { Other cows } \\
2 \text { years } \text { over } \\
\text { over }\end{array}$ \\
\hline Okla.. & $\$ 2210$ & $\$ 1069$ & $\$ 2378$ & $\$ 1810$ & $\$ 3042$ & $\$ 2269$ \\
\hline Ore... & 2165 & 913 & 2602 & 1755 & 3343 & 2490 \\
\hline $\mathrm{Pa} . . .$. & 2270 & 720 & 2971 & 1650 & 3088 & 2502 \\
\hline R. I... & 3235 & 853 & 3657 & 1921 & 3961 & 2756 \\
\hline S. C........ & 1264 & 412 & 1068 & 861 & 2006 & 1250 \\
\hline S. Dak. .... & 2447 & 1102 & 3138 & 1997 & 3104 & 2957 \\
\hline Tenn....... & 1688 & 681 & 1849 & 1319 & 2530 & 1940 \\
\hline Texas ...... & 1731 & 909 & 2073 & 1411 & 2322 & 1978 \\
\hline Utah. . & 2081 & 924 & 2303 & 1683 & 3091 & 2429 \\
\hline Vt..... & 2098 & 557 & 2894 & 1295 & 2865 & 2178 \\
\hline Va..... & 2040 & 786 & 2681 & 1430 & 2356 & 1985 \\
\hline Wash .. & 2390 & 846 & 2699 & 1826 & $\begin{array}{lll}38 & 01\end{array}$ & 2950 \\
\hline W. Va.. & 2197 & 822 & 2851 & 1644 & 2770 & 2431 \\
\hline Wis... & 202.5 & 659 & 2671 & 1587 & 2969 & 2505 \\
\hline Wyo.... & 2822 & 1411 & 3124 & 2282 & 3944 & 3239 \\
\hline
\end{tabular}


XV. AVERAGE VALUE OF HORSES AND MULES

Average value of horses and mules on farms and ranges, June 1, 1900, by states and territories

\begin{tabular}{|c|c|c|c|c|c|c|}
\hline \multirow[b]{2}{*}{$\begin{array}{l}\text { States and } \\
\text { territories }\end{array}$} & \multicolumn{3}{|c|}{ Horses } & \multicolumn{3}{|c|}{ Mules } \\
\hline & All horses & $\begin{array}{c}\text { Colts under } \\
2 \text { years }\end{array}$ & $\begin{array}{l}\text { Colts and } \\
\text { horses 2 } \\
\text { years and } \\
\text { over }\end{array}$ & All mules & $\begin{array}{c}\text { Colts under } \\
2 \text { years }\end{array}$ & $\begin{array}{c}\text { Mules } 2 \\
\text { years and } \\
\text { over }\end{array}$ \\
\hline Ala. & $\$ 5179$ & $\$ 3073$ & $\$ 5441$ & $\$ 6823$ & $\$ 3917$ & $\$ 7007$ \\
\hline Alaska...... & 9300 & $\ldots$ & 9300 & & & \\
\hline Ariz. ...... & 1361 & 561 & 1750 & 3030 & 2030 & 3340 \\
\hline Ark......... & 4008 & 2206 & 4265 & 5708 & 3189 & 6016 \\
\hline Cal......... & 4236 & 2468 & $44 \quad 59$ & 5439 & 2957 & 5812 \\
\hline Colo......... & 3090 & 1585 & 3496 & 4799 & 3154 & 5381 \\
\hline Conn........ & 7254 & 5269 & 7306 & 8178 & 5002 & 8773 \\
\hline Del......... & 5947 & 3543 & 6257 & 7279 & 5649 & 7404 \\
\hline D. of C...... & $67 \quad 17$ & 4917 & 6793 & $74 \quad 69$ & & 7469 \\
\hline Fla........ & 5349 & 2663 & 5660 & 7867 & 4555 & 7960 \\
\hline Ga... & 5567 & 3335 & 5724 & 6972 & 4216 & 7046 \\
\hline Hawaii..... & 3402 & 1626 & 3627 & 9076 & 3337 & $94 \quad 69$ \\
\hline Idaho ....... & 2424 & 1042 & 2829 & 3934 & 2719 & 4406 \\
\hline IIl. ........ & 5162 & 3149 & 5556 & 5953 & 3672 & 6589 \\
\hline Ind... & 5407 & 3405 & 5736 & 5571 & 3726 & 6081 \\
\hline Ind. Ter.... & 2859 & 1373 & 3188 & 5063 & 2800 & 5498 \\
\hline Iowa ....... & 5581 & 3207 & 6115 & 6434 & 4050 & 7174 \\
\hline Kans....... & 4467 & 2580 & 4806 & 5482 & 3428 & 6422 \\
\hline Ky........ & 5435 & 4871 & 5511 & 5825 & 3679 & 6423 \\
\hline & 3408 & 1751 & 3661 & 7388 & 3498 & 7599 \\
\hline Maine....... & 6641 & 3934 & $68 \quad 12$ & 5533 & 3764 & 6619 \\
\hline Md.. & 6277 & 3582 & 6661 & 7964 & 4799 & 8221 \\
\hline Mass & 7765 & 6437 & 7811 & 6941 & 4723 & 7918 \\
\hline Mich. & 6122 & 3432 & 6468 & 5435 & 3379 & 5953 \\
\hline Minn... & 6067 & 3043 & 6.547 & 5835 & 4110 & 6215 \\
\hline Miss........ & 4746 & 2785 & 5067 & 6594 & 3920 & 6843 \\
\hline Mo. & 4353 & 2735 & 4582 & $5 \pm 61$ & 3436 & 6360 \\
\hline Mont. . & 2360 & 1394 & 2681 & 3765 & 2599 & 4455 \\
\hline Neb..... & 4610 & 2547 & 5044 & 5753 & 3673 & 6379 \\
\hline Nev.... & 1585 & 726 & 1903 & 3066 & 1760 & 3881 \\
\hline N. H... & 7000 & 4642 & 7081 & 6260 & 3390 & 7236 \\
\hline N.J... & 8064 & 8132 & 8064 & 7243 & 5356 & 7343 \\
\hline N. Mex. & 1693 & 834 & 1985 & 3448 & 1928 & 3880 \\
\hline N. Y... & 7634 & 4574 & 7877 & 6917 & 4121 & 7276 \\
\hline N. C....... & 5527 & 3107 & $57 \quad 18$ & 6399 & 3621 & 6570 \\
\hline N. Dak. & 6314 & 2709 & 7037 & 6924 & 3898 & 7372 \\
\hline Ohio... & 5712 & 3517 & 6052 & $56 \quad 12$ & 3869 & 5966 \\
\hline Okla. & 3496 & 1942 & 3840 & 5080 & 3164 & 5659 \\
\hline Ore.... & 3005 & 1379 & 3376 & 4274 & 2437 & 5006 \\
\hline
\end{tabular}


XV. Average Value of Horses and Mules-Concluded

\begin{tabular}{|c|c|c|c|c|c|c|}
\hline \multirow[b]{2}{*}{$\begin{array}{l}\text { States and } \\
\text { territories }\end{array}$} & \multicolumn{3}{|c|}{ Horses } & \multicolumn{3}{|c|}{ Mules } \\
\hline & All horses & $\begin{array}{c}\text { Colts under } \\
2 \text { years }\end{array}$ & $\begin{array}{c}\text { Colts and } \\
\text { horses } 2 \\
\text { years and } \\
\text { over }\end{array}$ & All mules & $\begin{array}{c}\text { Colts under } \\
2 \text { years }\end{array}$ & $\begin{array}{c}\text { Mules 2 } \\
\text { years and } \\
\text { over }\end{array}$ \\
\hline Pa.. & $\$ 6929$ & $\$ 4033$ & $\$ 7269$ & $\$ 7640$ & $\$ 4923$ & $\$ 7960$ \\
\hline R. 1 . & 8612 & 6454 & 8655 & 7461 & *3250 & 769 \\
\hline S. C... & 6181 & 3826 & 6364 & 7170 & 4859 & 7216 \\
\hline S. Dak ..... & 4178 & 2044 & 4729 & 5079 & 3370 & 5655 \\
\hline Tenn...... & 5585 & 3541 & $\begin{array}{ll}59 & 01\end{array}$ & 6387 & 3704 & 7085 \\
\hline Texas. & 2718 & 1415 & 2950 & 4952 & 2562 & 5347 \\
\hline Utah.. & 2931 & 1454 & 3326 & 2781 & $197 \%$ & 3349 \\
\hline Vt. .... & $62 \quad 19$ & 3682 & 6405 & 6600 & 4154 & 7108 \\
\hline Va.... & 5134 & 3070 & 5446 & 6197 & 3754 & 6597 \\
\hline Wash .. & 3504 & 1397 & 4074 & 5137 & 3227 & 5943 \\
\hline W. Va... & 5603 & 3043 & 5996 & 6387 & 4124 & 6738 \\
\hline Wis.... & 6175 & 3392 & 6597 & 5423 & 4207 & 577 \\
\hline Wyo... & 2379 & 1184 & 2810 & 4206 & 2870 & 4933 \\
\hline
\end{tabular}

* Colts 1 year and under 2. 
XVI. AVERAGE VALUE OF SHEEP, SWINE AND GOATS Average value of sheep, swine and goats on farms and ranges, June 1 , 1900 , by states and territories

\begin{tabular}{|c|c|c|c|c|c|c|}
\hline \multirow[b]{2}{*}{$\begin{array}{c}\text { States and } \\
\text { territories }\end{array}$} & \multicolumn{4}{|c|}{ Sheep } & \multirow[b]{2}{*}{$\begin{array}{l}\text { Swine } \\
\text { all ages }\end{array}$} & \multirow[b]{2}{*}{$\begin{array}{c}\text { Gosts } \\
\text { all ages }\end{array}$} \\
\hline & All sheep & $\begin{array}{l}\text { Lambs } \\
\text { under } 1 \\
\text { year }\end{array}$ & $\begin{array}{l}\text { Ewes } 1 \\
\text { year and } \\
\text { over }\end{array}$ & $\begin{array}{c}\text { Rams and } \\
\text { wethers } 1 \\
\text { yr. and over }\end{array}$ & & \\
\hline Ala......... & $\$ 154$ & $\$ 119$ & $\$ 164$ & $\$ 175$ & $\$ 203$ & $\$ 080$ \\
\hline Alaska..... & $\ldots \ldots$ & $\ldots \ldots$ & & & 1000 & $\cdots \cdots$ \\
\hline Ariz........ & 206 & 136 & 235 & 227 & 445 & 171 \\
\hline Ark ......... & 170 & 140 & 184 & 192 & 174 & 113 \\
\hline Cal......... & 273 & 188 & 303 & 354 & 414 & 241 \\
\hline Colo........ & 273 & 165 & 314 & 389 & 477 & 195 \\
\hline Conn....... & 372 & 289 & 415 & 481 & 704 & 621 \\
\hline Del......... & 370 & 377 & 360 & 432 & 502 & 363 \\
\hline D. of C.... & ........... & $\ldots \ldots$ & $\because \cdots$ & ….. & 511 & 433 \\
\hline Fla......... & 192 & 149 & 195 & 209 & 151 & 75 \\
\hline Ga. & 130 & 109 & 136 & 138 & 181 & 73 \\
\hline Hawaii. .... & 131 & 66 & 142 & 152 & 615 & 112 \\
\hline Idaho ...... & 266 & 186 & 307 & 337 & 421 & 450 \\
\hline Ill.......... & 360 & 247 & 427 & 468 & 399 & 225 \\
\hline Ind.......... & 333 & 230 & 402 & 481 & 367 & 199 \\
\hline Ind. Ter.... & 223 & 164 & 237 & 257 & 293 & 205 \\
\hline owa ........ & 374 & 237 & 453 & 489 & 450 & 354 \\
\hline Kans....... & 318 & 204 & 367 & 381 & 475 & 390 \\
\hline Kу........ & 323 & 306 & 335 & 350 & 265 & 165 \\
\hline La ......... & 151 & 98 & 162 & I 78 & 190 & 93 \\
\hline Maine....... & 266 & 217 & 295 & 366 & 653 & 391 \\
\hline Id ......... & 364 & 337 & 378 & 445 & 418 & 341 \\
\hline Mass. . & 368 & 276 & 412 & 488 & 696 & 573 \\
\hline Mich ... & 261 & 173 & 314 & 418 & 394 & 350 \\
\hline Minn....... & 295 & 178 & 365 & 423 & 407 & 338 \\
\hline Miss ........ & 171 & 141 & 178 & 186 & 230 & 82 \\
\hline Mo... & 308 & 236 & 351 & 383 & 365 & 265 \\
\hline Mont... & 294 & 195 & 337 & 349 & 569 & 459 \\
\hline Neb........ & 328 & 188 & 395 & 431 & 452 & 380 \\
\hline Nev......... & 264 & 182 & 299 & 348 & 499 & 279 \\
\hline N. H...... & 294 & 233 & 329 & 386 & 698 & 440 \\
\hline N.J... & 424 & 391 & 443 & 580 & 528 & 430 \\
\hline N. Mex. & 217 & 151 & 240 & 299 & 400 & 211 \\
\hline N. Y....... & 339 & 255 & 397 & 546 & 561 & 490 \\
\hline N. C.... & 158 & 134 & 168 & 170 & 194 & 89 \\
\hline N. Dak..... & 291 & 155 & 351 & 371 & 485 & 473 \\
\hline Ohio... & 273 & 173 & 325 & 322 & 370 & $\begin{array}{ll}313 \\
\end{array}$ \\
\hline Okla ....... & 252 & 172 & 281 & 318 & 407 & 288 \\
\hline Ure... & 249 & 178 & 283 & 302 & 376 & 342 \\
\hline
\end{tabular}


XVi. Average Value of Sheep, Swine and Goats-Concluded

\begin{tabular}{|c|c|c|c|c|c|c|}
\hline \multirow{2}{*}{$\begin{array}{c}\text { States and } \\
\text { territories }\end{array}$} & \multicolumn{4}{|c|}{ Sheep } & \multirow{2}{*}{$\begin{array}{l}\text { Swine } \\
\text { all ages }\end{array}$} & \multirow{2}{*}{$\begin{array}{c}\text { Goats } \\
\text { all ages }\end{array}$} \\
\hline & All sheep & $\begin{array}{c}\text { Lambs } \\
\text { under } 1 \\
\text { year }\end{array}$ & $\begin{array}{c}\text { Ewes 1 } \\
\text { year and } \\
\text { over }\end{array}$ & $\begin{array}{c}\text { Rams and } \\
\text { wethers 1 } \\
\text { yr. and orer }\end{array}$ & & \\
\hline $\mathrm{Pa} \ldots . . . .$. & $\$ 303$ & $\$ 232$ & $\$ 345$ & $\$ 349$ & $\$ 526$ & $\$ 407$ \\
\hline R. $1 \ldots \ldots \ldots$ & 368 & 331 & 383 & 488 & 787 & 570 \\
\hline S. C........ & 156 & 133 & 164 & 169 & 228 & 92 \\
\hline S. Dak ..... & 314 & 177 & 380 & 417 & 430 & 516 \\
\hline Tenn....... & 238 & 207 & 255 & 266 & 245 & 150 \\
\hline Texas ....... & 211 & 138 & 220 & 257 & 285 & 147 \\
\hline Utah....... & 269 & 183 & $\begin{array}{lll}3 & 01\end{array}$ & 340 & 446 & 189 \\
\hline Vt...... & 297 & 198 & 355 & 420 & 652 & 435 \\
\hline Va......... & 302 & 272 & 321 & 355 & 272 & 189 \\
\hline Wash........ & 264 & 196 & 301 & 343 & 458 & 374 \\
\hline W. V........ & 275 & 219 & 313 & 321 & 314 & 251 \\
\hline Wis... & 269 & 171 & 332 & 422 & 376 & 329 \\
\hline Wyo..... & 320 & 203 & 376 & 401 & 505 & 446 \\
\hline
\end{tabular}




\section{DAIRY COWS AND DAIRY PRODUCTS}

\section{Dairy cows, June 1, 1900, and dairy products in 1899 on farms and ranges, by states and territories}

\begin{tabular}{|c|c|c|c|c|c|c|}
\hline \multirow{2}{*}{$\begin{array}{l}\text { Sitates } \\
\text { and } \\
\text { terri- } \\
\text { tories }\end{array}$} & \multirow{2}{*}{$\begin{array}{c}\text { Dairy cows } \\
\begin{array}{c}\text { Number } \\
\text { of cows }\end{array}\end{array}$} & \multirow{2}{*}{$\begin{array}{c}\text { Total } \\
\text { value of } \\
\text { dairy } \\
\text { products }\end{array}$} & \multicolumn{2}{|c|}{ Milk } & \multirow{2}{*}{$\begin{array}{c}\text { Butter } \\
\begin{array}{c}\text { Pounds } \\
\text { made }\end{array}\end{array}$} & \multirow{2}{*}{$\begin{array}{c}\text { Cheese } \\
\begin{array}{c}\text { Pounds } \\
\text { maule }\end{array}\end{array}$} \\
\hline & & & $\begin{array}{c}\text { Total number } \\
\text { gallons pro- } \\
\text { duced }\end{array}$ & Gallons sold & & \\
\hline la & 279,263 & $\$ 6,610,967$ & $95,882,103$ & $3,087,433$ & $19,121,964$ & 36,374 \\
\hline Alaska & 13 & 596 & 4,250 & 684 & 200 & \\
\hline Ariz... & 17,965 & 540,700 & $3,056,109$ & $1,022,472$ & 379,311 & 33,305 \\
\hline Ark. & 312,577 & $6,912,459$ & $109,861,393$ & $4,238,852$ & $21,585,258$ & 18,385 \\
\hline Cal. & 307,245 & $12,128,471$ & $153,684,711$ & $56,540,946$ & $20,853,360$ & $4,249,588$ \\
\hline Colo.... & 100,116 & $3,778,901$ & $38,440,111$ & $13,170,810$ & $4,932,482$ & 103,184 \\
\hline Conn... & 126,434 & $7,090,188$ & $68,951,862$ & $33,879,466$ & $4,591,789$ & 40,623 \\
\hline Del & 32,591 & $1,092,807$ & $12,681,268$ & $4,988,462$ & $1,629,949$ & 104 \\
\hline D. of C. & 1,251 & 186,096 & 850,349 & 661,335 & 3,478 & \\
\hline Florida. & 78,830 & $1,468,603$ & $9,640,434$ & $1,003,918$ & $1,386,445$ & 3,751 \\
\hline & 276,024 & $5,954,575$ & $82,438,532$ & $3,920,412$ & $15,111,494$ & 2,236 \\
\hline Hawaii. & 4,028 & 91,876 & 584,120 & 84,451 & 118,871 & 12 \\
\hline Irlaho & 51,929 & $1,243,197$ & $15,122,948$ & $2,789,638$ & $2,520,316$ & 196,952 \\
\hline & $1,007,664$ & $29,638,619$ & $457,106,995$ & $186,549,335$ & $52,493,450$ & 323,485 \\
\hline 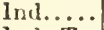 & 574,276 & $15,739,594$ & $263,457,239$ & $36,562,105$ & 5̄1,042,396 & 178,733 \\
\hline$\Gamma$ & 110,687 & $1,504,747$ & $26,493,855$ & 482,082 & $5,105,715$ & 1,227 \\
\hline low: & $1,423,648$ & $27,516,870$ & $535,872,240$ & $214,338,442$ & $61,789,288$ & 306,428 \\
\hline Kans.. & 676,456 & $11,782,902$ & $244,909,123$ & $47,939,088$ & $41,640,772$ & 291.445 \\
\hline & 025 & $9,985,540$ & $159,311,527$ & 259 & $30,446,381$ & 45,759 \\
\hline & 184,815 & $4,168,015$ & $39,251,413$ & $4,356,979$ & $4,918,229$ & 135,104 \\
\hline Maiut. & 173,592 & $8,182,344$ & $99,586,188$ & $15,979,003$ & $16,174,173$ & 425,102 \\
\hline Md. . & 147,284 & $5,228,698$ & $64,040,517$ & $20,654,446$ & $9,096,662$ & 338,453 \\
\hline 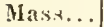 & 184,562 & $12,885,744$ & $105,571,873$ & $68,180,759$ & $4,980,262$ & 19,629 \\
\hline & 563,905 & $16,903,087$ & 7,046 & $55,635,108$ & 1,998 & 331,176 \\
\hline & 753,632 & $16,623,460$ & $304,017,106$ & $103,768,172$ & $41,188,846$ & 290,623 \\
\hline s. . & 299,318 & $6,064,513$ & $97,030,385$ & $2,041,443$ & $18.881,236$ & 28,572 \\
\hline & 765,386 & $15,012,360$ & $258,207,755$ & $25,954,163$ & $45,509,110$ & 323,439 \\
\hline & 036 & $1,669,978$ & $15,696,214$ & $3,162,568$ & $2,454,072$ & 30,924 \\
\hline & 512,544 & $8,595,408$ & $190,477,911$ & $23,492,560$ & $34,518,659$ & 264,430 \\
\hline & 13,606 & 433,391 & $4,446,071$ & $1,353,062$ & 569,523 & 94,082 \\
\hline & 115,036 & $5,591,272$ & $60,724,590$ & $28,9,88,306$ & $6,385,611$ & 104,339 \\
\hline & 157,407 & $8,436,869$ & $77,714,055$ & $50,726,011$ & $5,894,363$ & 24,377 \\
\hline N. Mex. & 16,775 & 499,423 & $3,009,657$ & 633,638 & 313,003 & 68,571 \\
\hline & $1,501,608$ & $55,474,155$ & $772,799,352$ & $445,427,888$ & $74,714,376$ & $2,624,552$ \\
\hline N. C... & 233,178 & $6,175,397$ & $89,525,749$ & $1,826,631$ & $16,913,802$ & 28,883 \\
\hline N. Dak. & 125,503 & $2,053,133$ & $48,845,280$ & $3,177,971$ & $9,178,815$ & 70,881 \\
\hline & 818,239 & $25,383,627$ & $425,870,394$ & $84,543,703$ & $79,551.299$ & $1,167,001$ \\
\hline & 165,852 & $2,481,673$ & $47,439,853$ & $2,701,471$ & $8,781,359$ & 45,264 \\
\hline
\end{tabular}




\section{The Farmer's Business Handbook}

XVII. Dairy Cows and DaIry Products-Concluded

\begin{tabular}{|c|c|c|c|c|c|c|}
\hline \multirow{2}{*}{$\begin{array}{l}\text { States } \\
\text { and } \\
\text { terri- } \\
\text { tories }\end{array}$} & \multirow{2}{*}{$\begin{array}{c}\text { Dairy cows } \\
\begin{array}{c}\text { Number } \\
\text { of eows }\end{array}\end{array}$} & \multirow{2}{*}{$\begin{array}{c}\text { Total } \\
\text { value of } \\
\text { dairy } \\
\text { produets }\end{array}$} & \multicolumn{2}{|c|}{ Mlilk } & \multirow{2}{*}{$\begin{array}{c}\text { Butter } \\
\begin{array}{c}\text { Pounds } \\
\text { made }\end{array}\end{array}$} & \multirow{2}{*}{$\begin{array}{l}\text { Cheese } \\
\begin{array}{c}\text { Pounds } \\
\text { made }\end{array}\end{array}$} \\
\hline & & & $\begin{array}{c}\text { Total number } \\
\text { gallous pro- } \\
\text { duced }\end{array}$ & Gallons sold & & \\
\hline Ore. & 122,447 & $\$ 3,550,953$ & $48,582,968$ & $10,308,119$ & $8,107,450$ & 467,256 \\
\hline & 943,773 & $35,860,110$ & $487,033,818$ & $171,045,659$ & $74,221,085$ & 857,167 \\
\hline & 23,660 & $1.923,707$ & $12,923,512$ & $9,685,988$ & 488,086 & 6,751 \\
\hline S. C. & 126,684 & $3,232,725$ & $44,031,528$ & $1,186,045$ & $8,150,437$ & 1,081 \\
\hline S. Dak. & 270,634 & $4,351,568$ & $99,244,975$ & $20,395,625$ & $17,400,970$ & 136,863 \\
\hline Tenn... & 321,676 & $8,028,466$ & ]47,3:36, 961 & $5,549,194$ & $29,091,696$ & 26,622 \\
\hline Tex & 861,023 & $15,516,978$ & $251,342,698$ & $8,091,205$ & $47.991,492$ & 136,133 \\
\hline Utah & 65,905 & $1,522,932$ & $25,124,642$ & $9,964,903$ & $2,812,122$ & 169,251 \\
\hline Vt. & 270,194 & $9,321,389$ & $142,042,223$ & $57,566,012$ & $18,834,706$ & 406,659 \\
\hline & 281,876 & $6,999,994$ & $105,068,428$ & $6,889,183$ & $19,905,830$ & 31,697 \\
\hline & 107,232 & $3,816,691$ & $50,182,415$ & $14,897,273$ & $7,372,106$ & 151,669 \\
\hline & 205,601 & $5,088,153$ & $83,861,660$ & $3,391,523$ & $16,913,129$ & 74,243 \\
\hline Wis. & 998,397 & $26,779,721$ & $472,274.264$ & $252,450,051$ & $44,739,147$ & $1,635,618$ \\
\hline Wyo & 18,272 & 421,613 & $5,121,974$ & 638,490 & 888,554 & 24,327 \\
\hline
\end{tabular}


XVII. COUNTIES HAVING $\$ 1,000,000$ AND UPWARDS OF
DAIRY PRODUCTS

\begin{tabular}{|c|c|c|c|c|c|}
\hline Counties & States & Value & Counties & States & Value \\
\hline 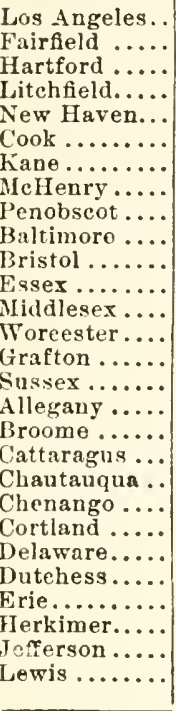 & $\begin{array}{l}\text { Cal. } \\
\text { Conn. } \\
\text { Conu. } \\
\text { Conn. } \\
\text { Coun. } \\
\text { Ill. } \\
\text { IIl. } \\
\text { IIl. } \\
\text { He. } \\
\text { Hid. } \\
\text { Mass. } \\
\text { Mass. } \\
\text { Mass. } \\
\text { Mass. } \\
\text { N. II. } \\
\text { N. Y. } \\
\text { N. Y. } \\
\text { N. Y. } \\
\text { N. Y. } \\
\text { N. Y. } \\
\text { N. Y. } \\
\text { N. Y. } \\
\text { N. Y. } \\
\text { N. Y. } \\
\text { N. Y. } \\
\text { N. Y. } \\
\text { N. Y. } \\
\text { N. Y. }\end{array}$ & $\begin{array}{r}\$ 1,024,712 \\
1,236,341 \\
1,361,503 \\
1.373,957 \\
1,024,353 \\
1,585,25 \% \\
2,177,289 \\
2.243,974 \\
1,002,581 \\
1,103,039 \\
1,036,062 \\
1,395,158 \\
2,258,790 \\
2,786,461 \\
1,078,035 \\
1,149,250 \\
1,143,621 \\
1,147,907 \\
1,896,109 \\
1,598,995 \\
2,008,480 \\
1,040,431 \\
2,920,399 \\
1,566,691 \\
1,706,062 \\
1,367,537 \\
2,112,276 \\
1,068,490 \\
\end{array}$ & 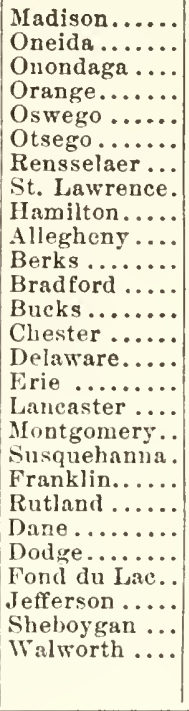 & $\begin{array}{l}\text { N. Y. } \\
\text { N. Y. } \\
\text { N. Y. } \\
\text { N. Y. } \\
\text { N. Y. } \\
\text { N. Y. } \\
\text { N. Y. } \\
\text { N. Y. } \\
\text { Ohio } \\
\text { Pa. } \\
\text { Pa. } \\
\text { Pa. } \\
\text { Pa. } \\
\text { Pa. } \\
\text { Pa. } \\
\text { Pa. } \\
\text { Pa. } \\
\text { Pa. } \\
\text { Pa. } \\
\text { Vt. } \\
\text { Vt. } \\
\text { Wis. } \\
\text { Wis. } \\
\text { Wis. } \\
\text { Wis. } \\
\text { Wis. } \\
\text { Wis. }\end{array}$ & $\begin{array}{r}\$ 1,249,769 \\
2,169,932 \\
1,451,470 \\
2,886,236 \\
1,173,610 \\
1,793,836 \\
1,021,011 \\
3,343,265 \\
1,442,801 \\
1,534,584 \\
1,459,330 \\
1,1 S 2,506 \\
1,583,162 \\
2,287,236 \\
1,020,031 \\
1,019,744 \\
1,731,899 \\
1,787,732 \\
1,034,384 \\
1,071,488 \\
1,026,082 \\
1,438,989 \\
1,294,649 \\
1,018,070 \\
1,241,598 \\
1,071,610 \\
1,292,966\end{array}$ \\
\hline
\end{tabular}


XIX. THE LIPORTANCE OF AGRICULTURE, AS A SOURCE OF NATIONAL WEALTH, AS EXHIBITED BY NEW YORK STATE 1899

The general importance of agriculture may be emphasized by noting the leading products and their value of that, state in the Union (New York), which on account of its position, and of the great number of cities and villages that have grown up within its borders, is generally supposed to be largely engaged in transportation and manufactures. Although a commercial state, its agriculture is nevertheless, of commanding importance. The last column shows the rank that New York takes among the states in the products enumerated:

\begin{tabular}{|c|c|c|}
\hline 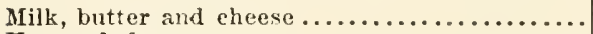 & $\$ 55,474,000$ & (1) \\
\hline 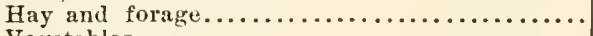 & $55,237,000$ & (2) \\
\hline 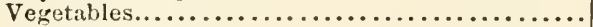 & $25,756,000$ & (1) \\
\hline 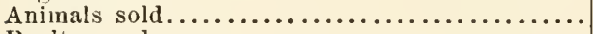 & $15,026,000$ & (14) \\
\hline Poultry and eggs $\ldots \ldots \ldots \ldots \ldots \ldots \ldots \ldots \ldots \ldots \ldots \ldots \ldots$ & $14,791,000$ & $(7)^{\prime}$ \\
\hline 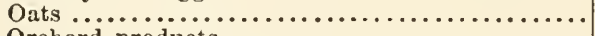 & $12,929,000$ & (7) \\
\hline Orchard products...$\ldots \ldots \ldots \ldots \ldots \ldots \ldots \ldots \ldots \ldots$ & $10,542,000$ & (2) \\
\hline Indian corn $\ldots \ldots \ldots \ldots \ldots \ldots \ldots \ldots \ldots \ldots \ldots$ & $9,182,000$ & (25) \\
\hline Animals slaughtered...$\ldots \ldots \ldots \ldots \ldots \ldots \ldots$ & $8,320,000$ & $(8)$ \\
\hline 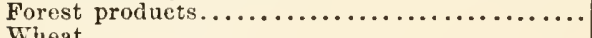 & $7,671,000$ & (1) \\
\hline 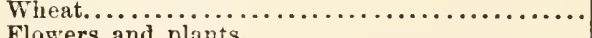 & $7,333,000$ & $(20)$ \\
\hline & $2,878,000$ & (1) \\
\hline 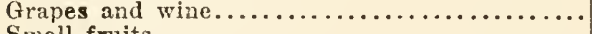 & $2,764,000$ & (2) \\
\hline 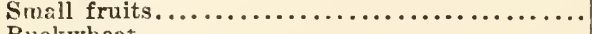 & $2,538,000$ & (1) \\
\hline Buekwheat..$\ldots \ldots \ldots \ldots \ldots \ldots \ldots \ldots \ldots \ldots \ldots \ldots \ldots \ldots \ldots \ldots$ & $2,046,000$ & (2) \\
\hline 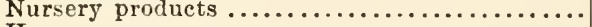 & $1,703,000$ & (1) \\
\hline 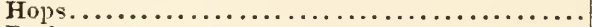 & $1,600,000$ & (1) \\
\hline 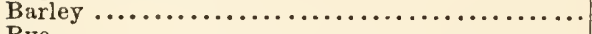 & $1,402,000$ & (8) \\
\hline 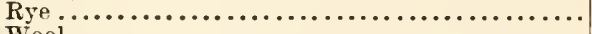 & $1,393,000$ & (3) \\
\hline 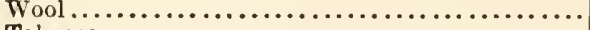 & $1,388,000$ & (13) \\
\hline 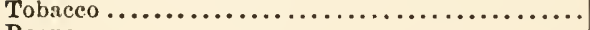 & $1.172,000$ & $(10)$ \\
\hline \multirow[t]{2}{*}{ 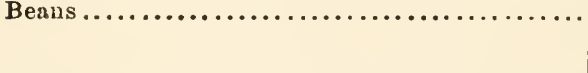 } & $2,-72,000$ & (1) \\
\hline & $\$ 243,717,000$ & \\
\hline
\end{tabular}


XX. VALUES OF FARM PROPERTY AND FARM PRODUCTS

The value of all farm property in the United States in 1900, as indicated in the Census Report, was $\$ 20,514,001,838$, while the capital invested in all forms of manufactures was $\$ 9,874,664,087$. The value of farm property might well be increased one-third, and then it would more nearly represent the actual value of the property on the market. The superiority of agriculture to manufactures is also indicated by the fact that while the horse-power employed in American factories, of all classes, during the year 1899 was 11,300,081, the number of working horses and mules on farms was $18,276,551$.

The values of the leading agricultural products of the United States, arranged in order of importance for the year 1899, were as follows:

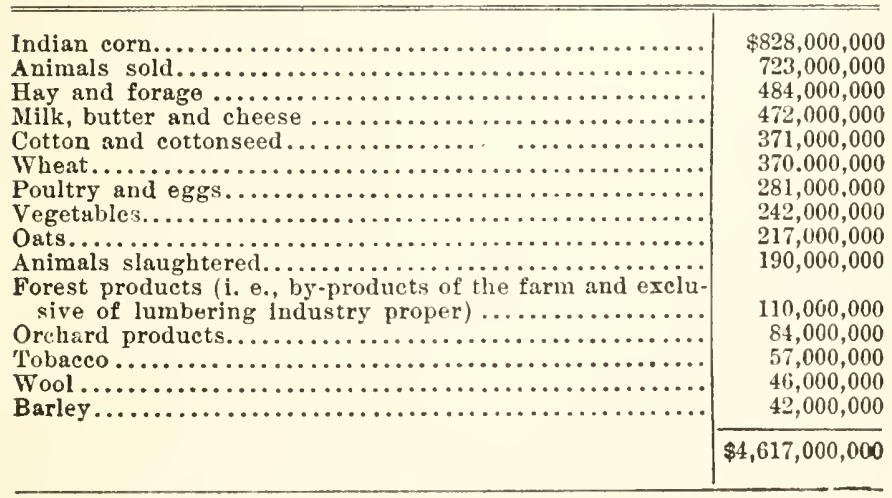


XXI. RELATIVE AGRICULTURAL RANKS OF VARIOUS STATES

The following tables will materially assist in locating the chief centers of the various agricultural products. They also furnish condensed statements in an easily accessible form. The preceding tables set forth in detail by states and territories all of the chief farm products. The tables that follow are designed for ready reference when information is desired as to quantities and values of the leading industries in any given state, and the totals of the same for the United States.

A. Value of total farm products in United States by decades from 1870-1900. (For comparison with following tables.)

\begin{tabular}{|c|c|c|c|}
\hline 1900 & 1890 & 1880 & $1870^{*}$ \\
\hline$\$ 4,739,118,752$ & $\$ 2,460,107,454$ & $\$ 2,212,540,927$ & $\$ 2,447,538,658$ \\
\hline \multicolumn{3}{|c|}{ Expended for fertilizers $\dagger$} & Expended for labor \\
\hline 1900 & 1890 & 1880 & 1899 \\
\hline$\$ 54,783,757$ & $\$ 38,469,598$ & $28,586,397$ & $\$ 365,305,921$ \\
\hline
\end{tabular}

B. Value of all crops for the year 1899, arranged by states in order of rank

\begin{tabular}{|c|c|c|c|c|}
\hline First & Second & Third & Fourth & Fifth \\
\hline $\begin{array}{c}\text { Illinois } \\
\$ 212,276,816\end{array}$ & $\begin{array}{c}\text { Iowa } \\
\$ 192,286,098\end{array}$ & $\begin{array}{c}\text { Texas } \\
\$ 163,444,678\end{array}$ & $\begin{array}{c}\text { Ohio } \\
\$ 151,226,461\end{array}$ & $\begin{array}{c}\text { New York } \\
\$ 142,247,245\end{array}$ \\
\hline
\end{tabular}

Pennsylvania, $\$ 120,512,960$; Indiana, $\$ 117,266,815$, and Missouri, over $\$ 117,000,000$; Minnesota, over $\$ 113,000,000$, and Kansas, over $\$ 112,000,000$ worth of crops.

Total value of all crops in the United States, $\$ 2,910,138,663$.

* Value in 1870 reported in depreciated curreney. Diminish by one-fifth; in. cludes betterments and additions to live stock.

fFor year preceding that designsted. 


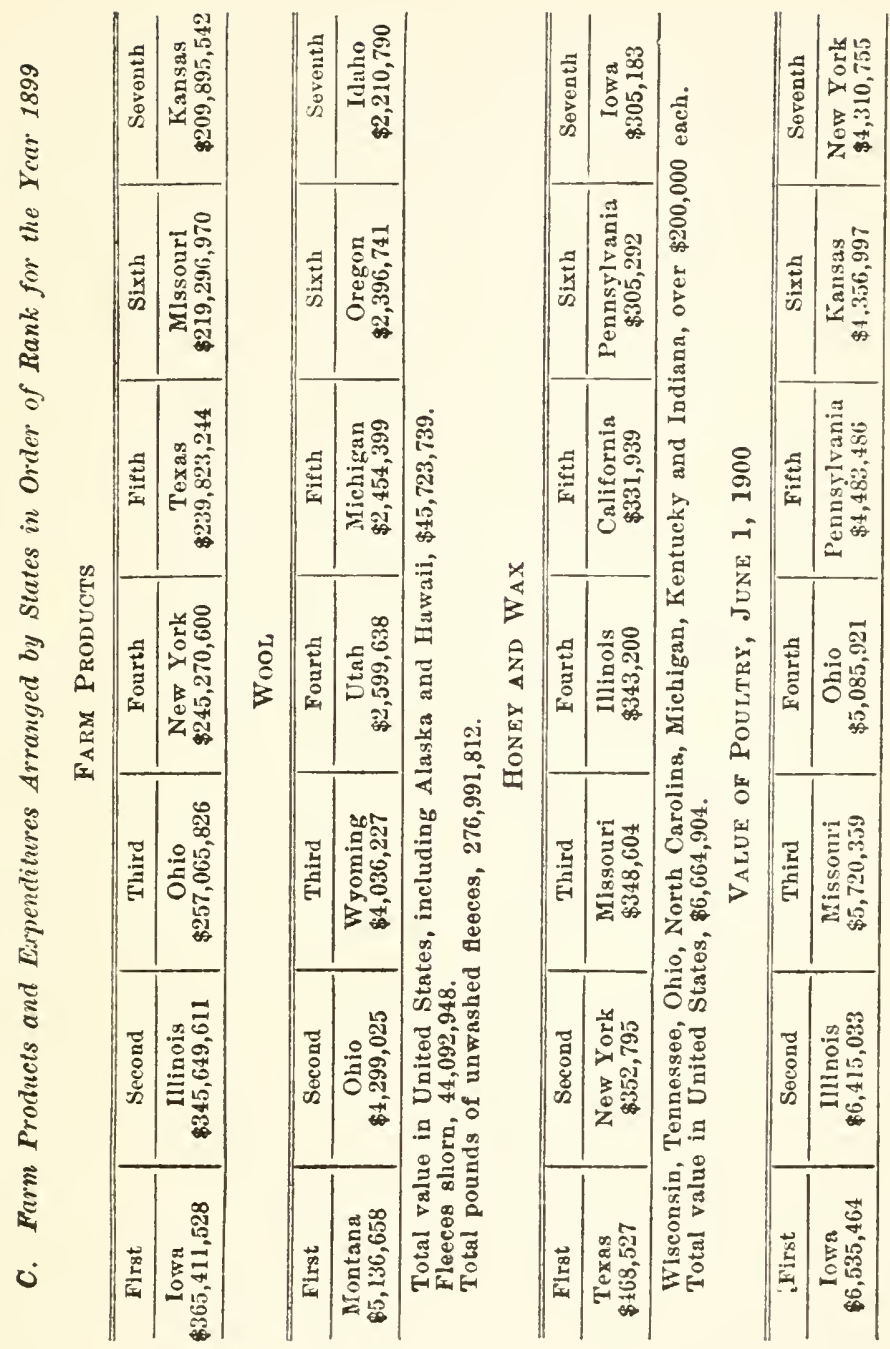




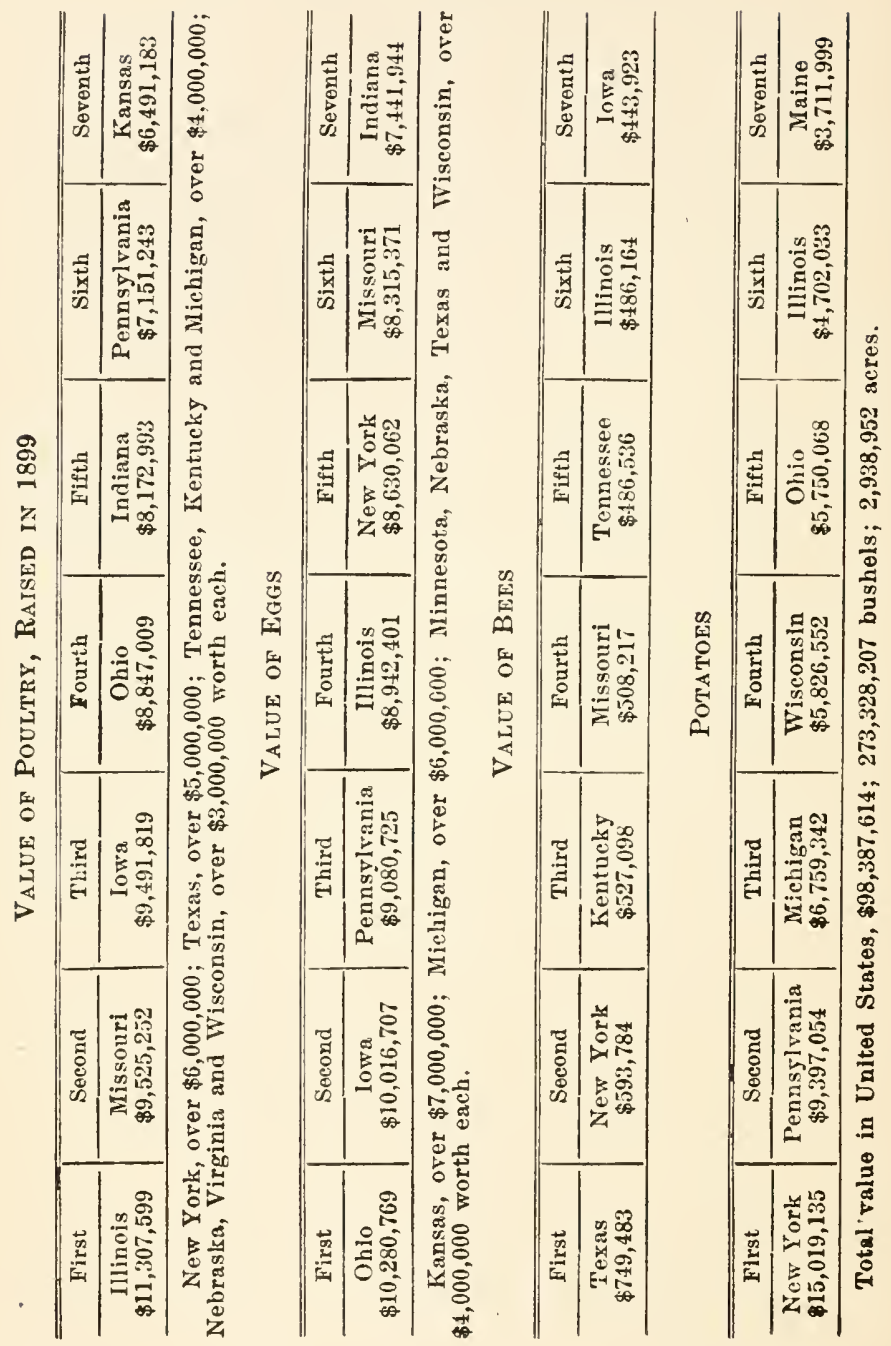


Values of Farm Products
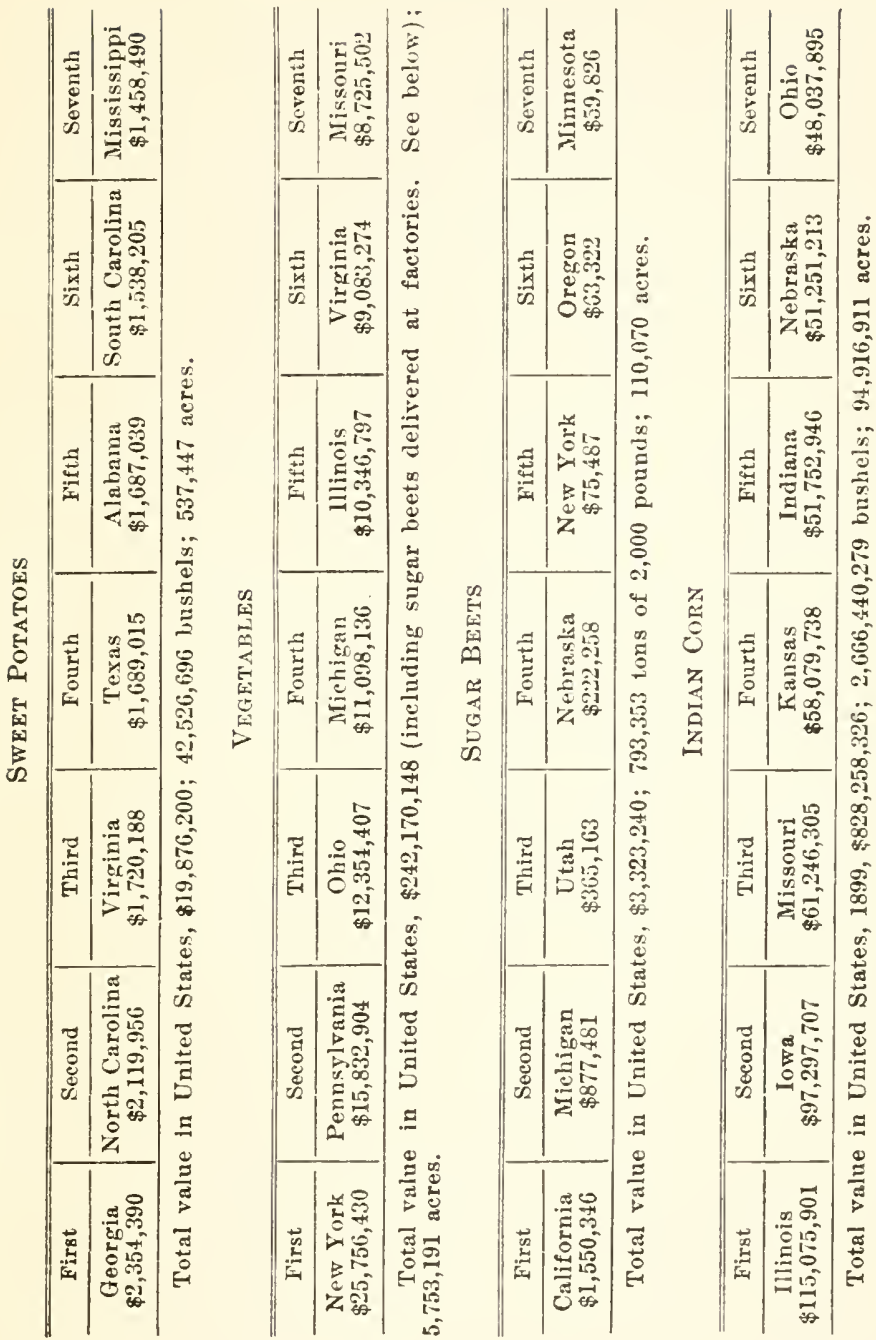
The Farmer's Business Handbook
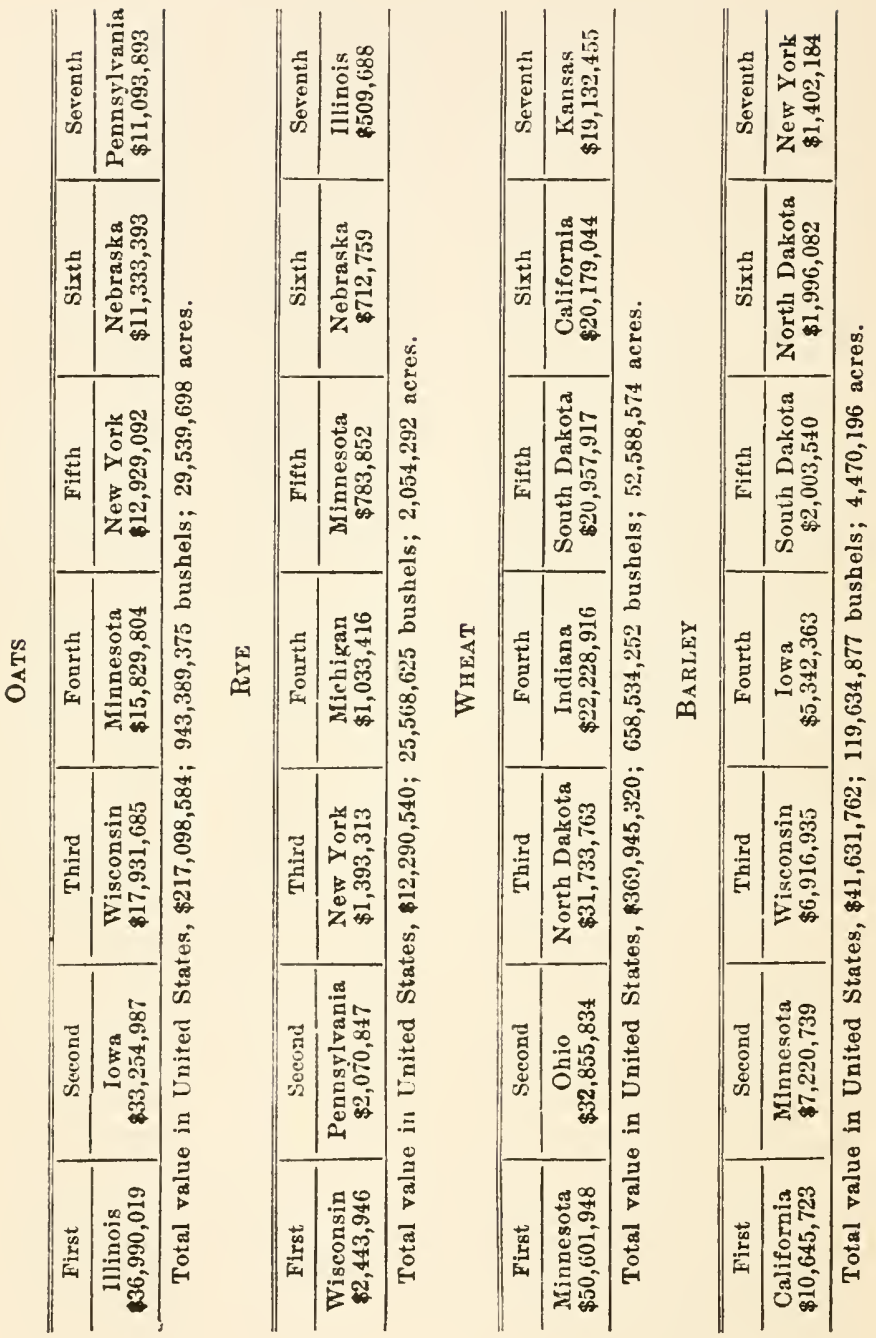


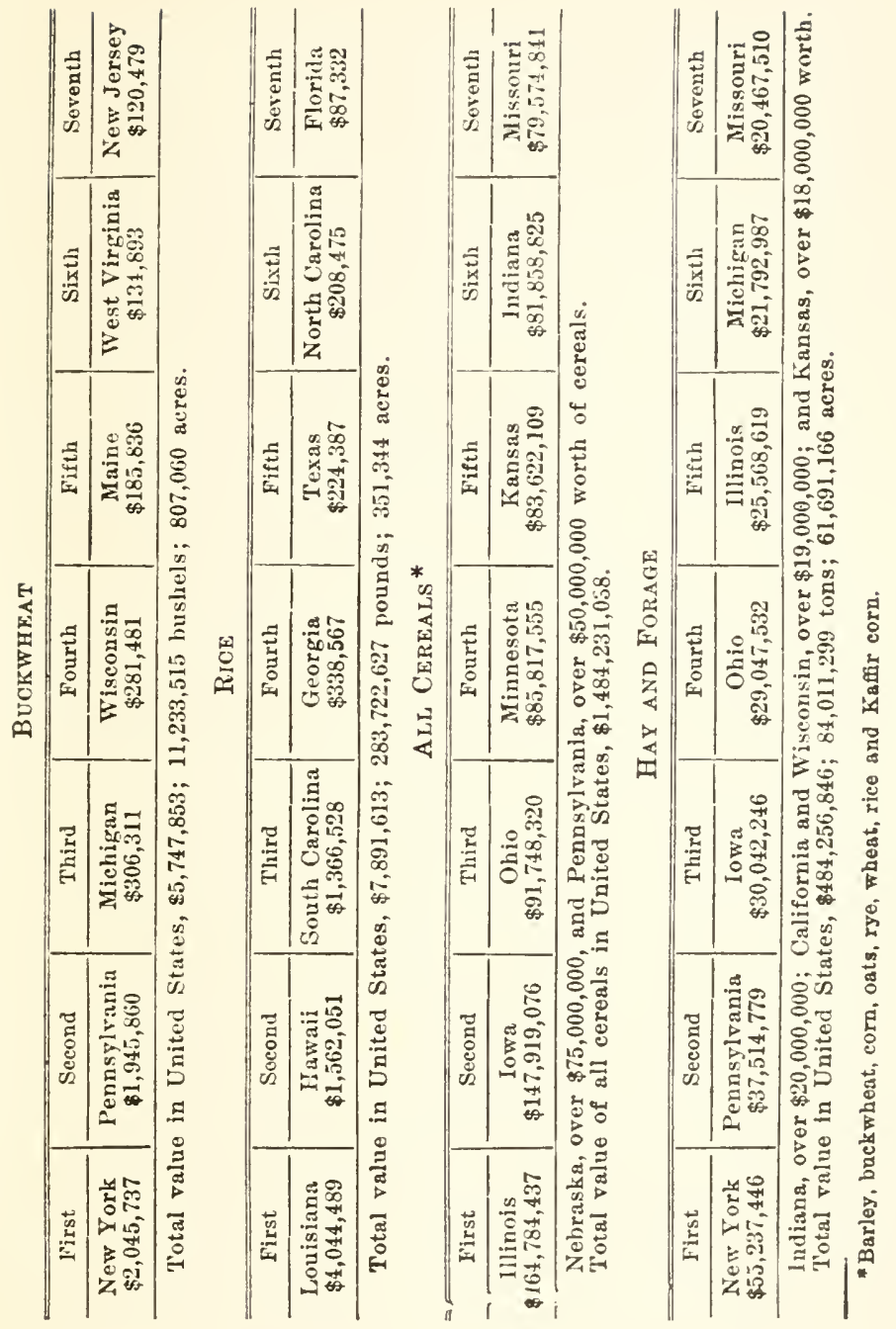


The Farmer's Business Handbook
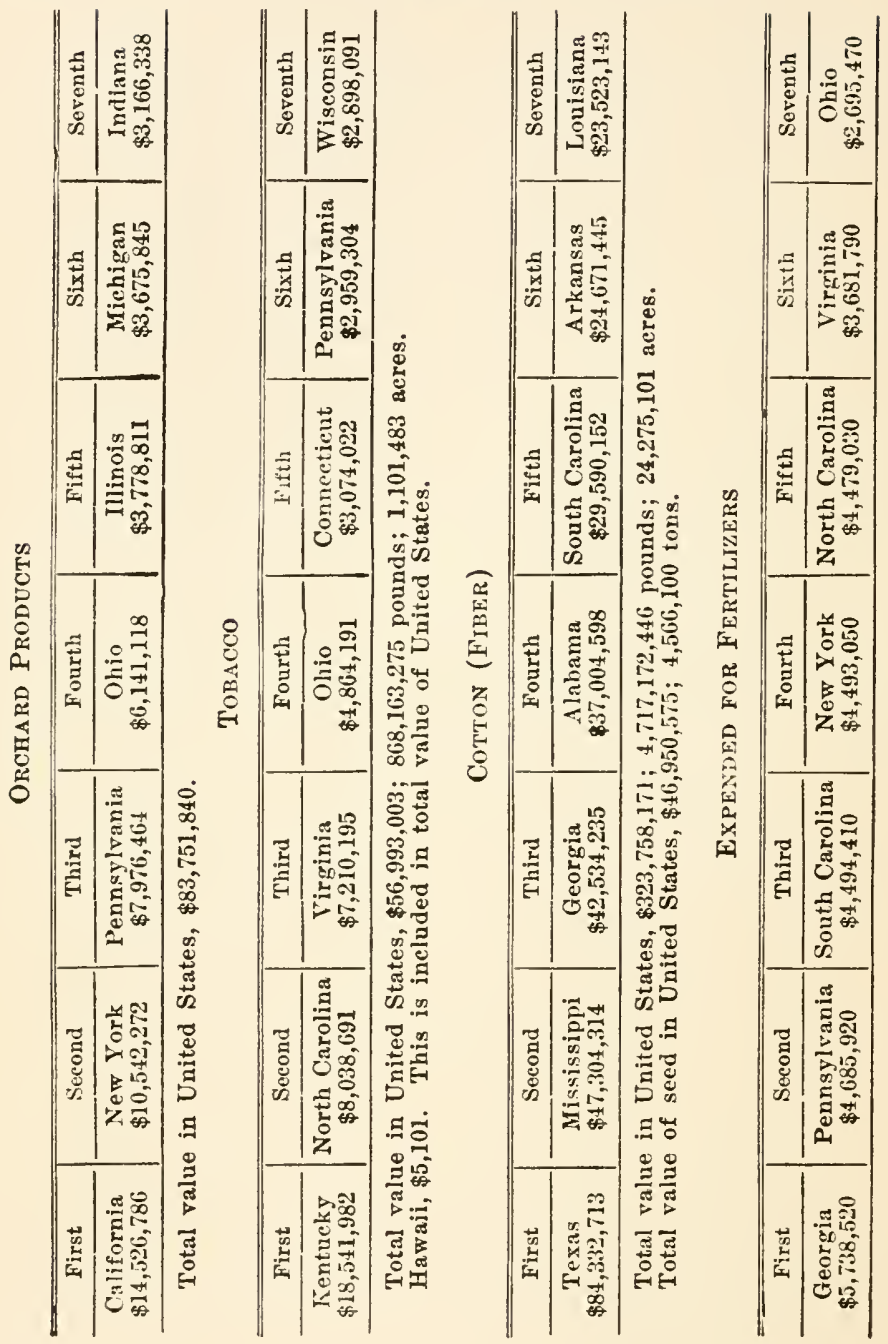
XXI. RELATIVE NUMBER OF PERSONS ENGAGED IN AGRICULTURE

When the attempt is made to discover the proportion of persons who make their living by agriculture in the United States, a serious difficulty arises from the fact that fully nine per cent of all persons having an occupation reported are tabulated simply as laborers. These have been thrown into the class of "Domestic and Personal Service," but might perhaps better be classed as "Unknown." The figures of the Twelfth Census on this point are as follows:

Number and per cent of persons at least ten years of age engaged in specified kinds of gainful occupation

\begin{tabular}{|c|c|c|}
\hline & Number & Per cent \\
\hline Agricultural pursuits....... & $10,438,219$ & 35.7 \\
\hline Professional service....... & $1,264,735$ & 4.3 \\
\hline Domestic and personal service... & $5,691,746$ & 19.4 \\
\hline Trade and transportation. & $4,778,233$ & 16.3 \\
\hline Manufacturing and mechanical products ..... & $7,112,987$ & 24.3 \\
\hline 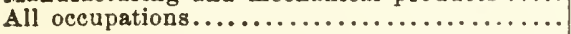 & $39,285,922$ & 100. \\
\hline
\end{tabular}

There is no means of ascertaining the number of persons residing in cities and villages who, in addition to their chief occupations, also are engaged to a greater or less extent in the profession of agriculture. It is probable that there are enough of them to bring up the total number of those engaged in agriculture to about fifty per cent of the total population. 
XXIII. AGRICULTURAL EDUCATION

As to the development of education in agriculture, the only statistics to be found are in the annual reports of the Commissioner of Education. In those reports, ever since 1894, the figures have been given separately for the college students of agriculture in the Land Grant Colleges of the United States. They are as follows:

\begin{tabular}{|c|c|}
\hline Acsdemic Year & $\begin{array}{l}\text { Collegiate students of } \\
\text { Agriculture in Land } \\
\text { Grant Colleges }\end{array}$ \\
\hline 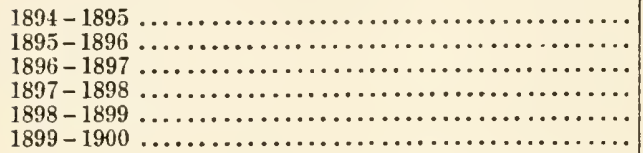 & $\begin{array}{l}2,712 \\
2,881 \\
3,053 \\
3,190 \\
4,390 \\
5,035\end{array}$ \\
\hline
\end{tabular}

In addition to the above, not less than two hundred thousand students are being taught, at their homes, in subjects related to agriculture. Some of these pupils are school children from twelve to eighteen year's of age, but many of them are farmers, mostly young men, and their wives. Without doubt, these correspondence courses are of great value and will result, in the end, in augmenting the number of students in the colleges of agriculture. The recent nature-study movement is also certain to produce a healthy interest in the agricultural courses now offered by every state in the Union. 


\section{INDEX}

Abstracts, necessity of, 162; of deeds, 160 ; of titles, 159; of wills, 161.

Accounts, defined, 23; easy method of keeping, 83; how closed, 60 , 74 ; incidental, 27, 35 ; labor (see Work Report); method of bulancing, 24, 74; need of, 1-7, 245 ; particular crops, 82 ; personal 26; posting, 29, 52-57, 70 , 73; property, 23; subdivisions of, $29-38,59,78$; teaching of, in schools, vi, 5, 20; three kinds of, 23 ; two, with wheat, 34 .

Acreage, farm erops, 250; farm lands, 250; rented farms, 253; rented farms per owner, 251, 257.

Afldavit, how to make, 242.

Agent, contract signed as, 204 .

Ageuts, frauds by, 204, 216.

Agreements. See Contracts.

Agrlculture, relative ranks of states in, 284, 285; vs. other industries, $283,284$.

Agricultural education, 292; labor, amount expended for, 284; population, 248; population, relatire, 291 ; products, by decades, 284 ; students, number of, 292.

Albuminoids. See Protein.

Alfalfa, digestible nutrients in, 126, 129; fertility in, 138.

Ammonium sulfate, analysis of, 139.

Animals, account witb, 101 ; amounts received from sale of, 271; composition of, 117; estrays, 170; lien for care of, 213 ; number not on farms, 259 ; number per 100,000 acres, 261 ; rations of, 116; trespass by, 170 , $186,188,189,190$; value of
United States product, 269-283; value of New York procluct, 282; warranty of, 205.

Apple, orchard, account with, 94; pomace, digestible nutrients in, 136.

Apples, digestible nutrients iu, 136; test of varieties, 97.

Armsby, quoted, 122.

Ashes, analysis of, 139.

Ash, composition of, 118; in feeds, 138; in fertilizers, 139 ; in food materials, 118; per cent of in animals, 117.

Asses, total number of, 265.

Assets, 11, 12, 53, 56, 72, 81, 144.

Attorney, a power of, 241.

Automobiles, on bighways, 179.

Balance, defined, 24 ; for weighing milk, 101, 107; trial, 55, 70; sheet, 81 .

Balanced ration, 124, 140-142.

Balaneing accounts, $24,60,74$.

Barbed wire fences, 184, 189.

Barley, digestible nutrients in, 131; fertility in, 138; value of, by states, 288; value of New York product, 282; value of United States product, 283.

Bean straw, digestible nutrients in, 130; fertility in, 139.

Beans, value of New York product, 282.

Bees, value of, by states, 286; value of honey and wax, 285.

Beet (see Sugar Beet), ruangel, digestible nutrients in, 127; mangel. fertility in, 138.

Betting, 202.

Bicyele paths on highways, 180.

Bills payable, 44, 45; ledger account with, 60 . 
Bills receivable, 44; ledger account with, 60 .

Bill of sale, 227.

Blood meal, analysis of, 139.

Blotter, 42; defined, 29; green. house account, 92,96 ; posting accounts from, 57 ; sample, 47 , 86.

Board, lien for, 213.

Bone black, analysis of, 139.

Bone meal, analysis of, 139 .

Bookkeeping, defined, 23; in schools, ri, 5, 20.

Boundary, line fences may become, 191.

Bran, digestible nutrients in, 132, 133.

Brewer's grain, digestible nutrients in, 134; fertility in, 138.

Bridges, capacity of, 179 .

Brown, Peter, ledger account with, 68.

Bryant, John, ledger account with, 68.

Buck wheat, digestible nutrients in, 131; fertility in, 138; value of New York product, 282; value of, by states, 289.

Buckwheat middlings in a ration, 141.

Burros, total number of, 265.

Butter, amount produced, 279, 282, 283.

Butter-fats, effect on weiglit of milk, 107; standard of, in milk, 105.

Buttermilk, digestible nutrients in, 137.

Cabbage, digestible nutrients in, 136; fertility in, 139.

Carbohydrates, 116; fat equivalent of, 119, 120; in feeding standards, 123, in food materials, 119.

Carrots, digestible nutrients in, 128; fertility in, 138.

Cash, ledger account with, 60 ; rules for debit and credit, 24,58 ; sample account, 23.

Cattle, feeding standards for, 123; number and value by elasses, 270; number not on farms or ranges, 259; number on farms and ranges, 269; number per
100,000 acres, 261 ; total number of, 263; value per head, 273. See, also, Dairy Cows.

Census, cost of, 246; reports, 245.

Chattel mortgages, 222, 225.

Cheese, amount produced, 279, 282, 283.

Clover. See Red Clover.

Commercial Fertilizers. See Fertilizers.

Commissioners of highways, rights and duties, 173-175, 179-182, 184, $185,189$.

Common law, defined, 202.

Compounding rations, 120.

Composition of animal bodies, 117.

Composition of food materials, 117.

Contingent account, 35, 37.

Contingent, ledger account with, 60.

Contracts, 193; by correspondence, 195; consideration necessary, 197; duress, in making, 201; for personal property, 155, 196; for realty, 155 ; fraud in making, 200 ; guaranty for another, 197; how to make, 193, 202; illegal, 201; lien to secure, 210; mis. take in making, 200; outlawed, 203; signiug for a stranger, 204, 216; undue influence in making, 201 ; verbal, 196 ; warranty of an animal, 205; who may make, 198.

Corn, digestible nutrients in, 130 ; fertility in, 138; value of New York product, 282; value of United States product, 283; value of, by states, 287.

Corn and cob meal, digestible nutrients in, 132; fertility in, 138.

Corn field, ledger account witl, $64,87$.

Corn fodder. digestible nutrients in, $126,129$.

Corn silage, digestible nutrients in, 127; fertility in, 138.

Corn stover, digestible nutrients in, 129; fertllity in, 138.

Cornell Experiment Station, quoted, 117.

Cotton, value of Unlted States product, 283 ; value of, by states, 290. 
Cotton-seed meal, digestible nutrients in, 135: fertility in, 139; in a ration, 142.

Covenant deed, full, 156.

Cover-crop, 96.

Credit. See Debit.

Creditor, defined, 28.

Crops, removal of, by tenant, 167 .

Dairy account, errors in keeping, 109.

Dairy cows, feeding standards for, 123; number of, 263,279 ; number on farms and ranges, 270; nutritive ratio for, 116 ; rations for, 140-142; total number of, 263; value of an account with, 102; value per head, 273. See, also, Nilk.

Dairymen, number of, 248.

Dairy products, amount and value of, 279 ; counties haring $\$ 1,000$,000 worth of, 281 ; value of, 282 , 283.

Day-book. See Blotter.

Days of grace, 216.

Debit and credit, rules for, 42,43 , $57,58$.

Debit and credit rules, for cash account, 24 ; for personal accounts, 26 ; for property accounts, 25.

Debtor, defined, 28.

Deed, full covenant, 156; how to make, 157, 158; recording of, 157; quit-claim, 157; warranty, $156,239$.

Deeds, 156; abstracts of, 160 .

Division fences. See Fences.

Doe, John, ledger account with, 68 .

Dogs, sheep killed by, 171; taxation of, 171; vicious, 171 .

Double-entry, 28, 35, 38, 58.

Dower right of wife, 155.

Drainage, 171, 173.

Driving. See Highways.

Drunken person, contract with, 199.

Due-bills, 224.

Duress, 201.

Education, agricultural, 292.

$\mathrm{E}_{\mathrm{g}}$ production, cost of, 112; receral of, 113; value of, by states, 286 .
Employee, responsibility of em. ployer for, 208.

Employer, responsibilities of, 208.

Engines on highways, 178.

Estate. See Wills.

Estray, animals, 170.

Expense, personal, account with, $35-37$.

Family, chat with, 147; flnancial condition of, 17.

Farm accounts. See Accounts.

Farm, acreage of crops, 250 ; inventory of, 13; value of crops per acre, 250.

Farmer, ledger account with, 68.

Farm-household account, 143.

Farm products, account with, 59; inventory of, 51 ; ledger account with, 62 ; value of, 269-290.

Farm property, value of United States, 283.

Farm tools, ledger account with, 62 .

Farms, rented, acreage of, 253; number and size of, 251; number of owners, 257; value of, 255.

Fat, per cent of, in animals, 117 .

Fats, in food materials, 118; starch equivalent of, $119,120$.

Feeding, economical, 124; principles of, 117.

Feelling standards, 121; table of, 123.

Feeds, digestible nutrients in, 126 ; elements of fertility in, 138.

Fences, 184; along streams, 186; barbed wire, 184, 189; boundary, 191; line, 185; fruit along, 187; live, 190 ; railroad, 185 ; road, 190.

Fence-viewers, duties of, 184, 185, 189.

Fertilizers, amounts expended for, 284,290 ; analysis of, 139; value of feeds as, 138.

Financial carelessness, $1-7$.

Fishing. See Hunting.

Flour, digestible nutrients in, 133.

Food materials, composition of, 117.

Forcing-house. See Greenhouse.

Forest products, ralue of $\mathrm{New}$ York, 282; value of United States, 283. 
Fraud, 200; by agents, 204-216.

Fruit, along line fences, 187; value of New York product, 282.

Gain and loss, account with, 73; how found, $12,25,56,72,75,84$; ledger account with, 76 ; sonrces of, $3,21,38,88$.

Game. See Hunting.

Gifts, 228; delivery of property necessary, 229; of real projerty, 229 ; in contemplation of death, 230 ; to avoid payment of debts, 231.

Gilbert, Sir Henry, quoted, 4.

Gluten, digestible nutrients in, 134; fertility in, 138.

Goats, number per 100,000 acres, 261 ; total number of, 267 ; value per hend, 277.

Gomez, General, mentioned, 246.

Governnient notes, 221.

Grain, digestible nutrients in, 130.

Grapes, value of New York products, 282.

Greenhouse, account of heating cost, 90; sample account with, 92 ; value of New York products, 282 ; work report of, 91 .

Greenhouses, account with, 88.

Guano, analysis of, 139.

Guaranty, for another, 197; of an animal, 205; of a note, 220-222.

Guide-hoards on highways, 182.

Hay, digestible nutrients in, 128; fertility in, 138; value of New York product, 282; value of United States product, 283; value of, by states, 289 ; weigh. ing for feeding, 108, 110

Hay fleld, ledger account with, 64.

Henry, W. A., quoted, 125.

Highways, automoblles on, 179; capacity of bridges on, 179; commissioners of, 173-175, 179-182, 185 , 190; driving on car track, 178; driving stock on, 178,179 , 190; engines on, 178; fences along. 190; guide-boards on, 182 ; impassahle, 175-180; line fences along, 190; obstruction of, 175,
178; passing vehicles on, 176; rights of adjacent owners, 174; rights of public, 174; side-paths on, 180 ; trees along. 174, 181; trespass of stock on, 190 ; water. ing - troughs on, 181; weeds along, 182 .

Hogs. See Swine.

Hominy chop, digestible nutrients in, 135; fertility in, 138.

Honey. See Bees.

Hops, value of New York product, 282.

Horse-power on farms and in fac. tories, 28.3.

Horses, feeding standards for, 123; number per 100,000 acres, 261; number not on farms or ranges, 259 ; nutritive ratio for, 116 ; total number of, 265 ; value per head, 275.

Hotel, lien for bill, 213.

Household account, 35, 38, 53, 54, 143.

Household goods, inventory of, 8 . Hungarian grass, digestible nutrients in, 127; fertility in, 138.

Hungarian hay, digestible nutrients in, 128.

Hunting, signs forbidding, 170; trespass b5, 153, 170.

Illinois, rank of, in agriculture, 284, 285.

Improvements, hauling manure charged to, 80; ledger account with, 66 .

Incidental accounts, 27, 35.

Inheritence of property, 155.

Insane person, contracts of, 199.

Interest, if none is stated, 218; legal rate of, 237; usury, 237.

Inventories from the census, 245.

Inventory, $7,53,72,144$; at end of year, 11, 17, 46; care in taking. 82, 114; of farm, 13; of farm produce, 51, 76; of household goods, 8, 143; posting, 54, 56, 70, 73; sample, 9; time to take, $7,89,143$.

Iowa, rank of, in agriculture, 284, 285.

Journal, 96; defined, 29. 
Kainlt, analysis of, 139 .

Kinds of accounts, 22.

Labor, account with. See Work Report.

Land-grant colleges, students in, 292.

Landlord. See Lease, and Tenant.

Law, rural, 153.

Lawes, Sir J. B., quoted, 80.

Lease, how to make, 163,166 ; implied agreements of, 166 ; of real property, 159; renewal by holding over, 166.

Ledger, 46, 53 ; balancing, 60 ; closing, 52 ; defined, 29 ; how closed, 74; bow opened, 64 ; object of, 59 ; opening entries, 54 ; posting accounts to, 57; posting balances and inventories, 70,73 ; proving the correctness of, 54 , 70 ; sample, 60 .

Legal contracts. See Contracts.

Legal fences. See Fences.

Legal tender, 243.

Liabilities, 72,81 .

Lien, artisan's, 212; by hotels, etc., 213; defined, 210 ; mechanic's, 210; mechanic's, how to secure, 211 ; on animals for care of, 213 ; tax, 238.

Line fences. See Fences.

Linseed meal, digestlble nutrients in, 135; fertility in, 138.

Live stock, subdivisions of, account with, 59 .

Loss. See Gain.

Maize. See Corn.

Malt sprouts, digestible nutrients in, 133; fertility in, 138.

Mangel - wurzel, digestible nutrients in, 127; fertility in, 138.

Manure, account with, 79, 86; duration of good effects of, 79 .

Mason, H. D., Part II, 153.

Mechanic. See Lien.

Milk (see, also, Dairy); accounts with, 101; amount produced, 279 ; digestible nutrients in, 137 ; fertility in, 139; how to weigh, 101, 107; legal standard of, in New York, 105; value of New
York product, 282; value of United States product, 283.

Milk report, a sample, 103.

Minor, contracts of, 198.

Mortgage, chattel, 222, 225.

Mortgages, advisability of, 14 .

Mules, number per 100,000 acres, 261 ; not on farms or ranges, 259 ; total number of, 265 ; value per head, 275.

New York, agricultural products, 282 ; rank of, in agriculture, 282, $284,285$.

Nitrate of potash, analysis of, 139. Nitrate of soda, analysis of, 139.

Nitrogen, amount of, in feeds, 138; amount of, in fertilizers, 139 ; in proteids, 117.

Nitrogenous matter. See Protein.

Notes, consideration necessary, 214 ; fraudulent, 204, 216, 223; days of grace, 216; demand, 218; endorsement of, 217; for patent rights, 222; guaranty of payment, 220; government, 221 ; interest on, 218; joint, 219; legal interest on, 237; liability of endorser, 215,217; negotiable, 214; 218; never sign to or for a stranger, 204, 216, 223; nonnegotiable, 218; payment of, fraudulent. 214; promissory,214; protecting by collateral, 222 ; protest of, 217,218 ; sample, 118,219 ; surety for, 220 ; usury, 237.

Nutritive ratio, 116, 123; defined, 120.

Nursery products, value of, New York, 282.

Oat field, account with, 86 ; ledger account with, 68 .

Oat straw, digestible nutrients in. 130; fertility in, 138.

Oats, digestible nutrients in, 131; fertility in, 138; value of New York product, 28: ; value of United States product, 283; value of, by states, 288 .

Ohio, rank of, in agrioultare, 284, 285. 
Orchard, account with, 94; ledger sccount with, 66 ; sample account with, 98.

Orchard products, total quantity of, 290; value of New York, 282; value of United States, 283, 290; value of by states, 290 .

Orders, 224.

Outlawed contracts, 203.

Overseer of highways, 174.

Panama canal, 246.

Patent rights, notes for, 223.

Peas, digestible nutrients in, 132; fertility in, 138.

Peas and barley, digestible nutrients in, 126 ; fertility in, 138.

Peas and oats, digestible nutrients in, 126; fertility in, 138.

Pea-vine straw, digestible nutrients in, 130 ; fertility in, 138.

Pension money free from taxes, 239.

Pennsylvania State College, 122, $1: 3$.

Personal accounts, 26; debit and credit explained, 58.

Personal property, contract for, 155, 196; defined, 154, 167; inheritance of, 155 .

Peruvjan guano, analysis of, 139.

Phosphoric acid, amount of, in feeds, 138; amount of, in fertilizers, 139.

Population, agricultural, 248, 291.

Posting accounts, 29, 52; from Blotter, 59; from Work Report, 38,57 ; inventories, $54,56,70$, 73 .

Potash, amount of, in feeds, 138; amount of, in fertilizers, 139.

Potassium muriate, analysis of, 139.

Potassium sulfate, analysis of, 139.

Potatoes, digestible nutrients in, 127; fertility in, 138; sweet, value of, by states, 287 ; value of, by states, 286 .

Poultry, accounts with, 110; egg record, 113; sources of loss in keeping, 111; value of, by states, 285,286 ; value of Nit York product, 282; value of Uniteả States product, 283 ; weekly report of, 115.

Power of attorney, 241.

Present worth, 38, 143.

Principles of feeding, 117.

Profit. See Gains.

Promissory notes. See Notes.

Property accounts, 23; debit and credit explained, 58; rules for debit and credit, 25.

Property, classes of, 153; defined, 153; personal (see Personal Property); real (see Real Property).

Proteids, 116.

Protein in feeding standards, 123; in food materials, 119; percentage of, in animals, 117.

Quit-claim deed, 157.

Railroad fences, 185.

Rations, balanced, 124, $140-142$; compounding of, 120 ; for farm animals, 116 ; how to use tables for, 140; "narrow," 116, 121, 141; "wide," 116, 121, 141; weighing for cows, 102, 105, 108, 110 ; weighing for poultry, 112.

Real estate. See Real Property.

Real property, coutracts of a minor, 199; conveyance of, 155 , 156,158 ; defined, 153, 167 ; dower of wife in, 155; gifts of, 229 ; inheritance of, 155; lease of, 159 , 163; purchased with pension money, 239: wills of, 235.

Realty. See Real Property.

Receipts, 224.

Recording deed, 157; leases, 163.

Red clover, digestible nutrients in, 126, 129; fertility in, 138.

Rent. See Lease.

Rented farms, acreage of, 253; number and size of, 251: number of owners of, 257; value of, 255.

Renting land, advisability of, 15 .

Rice, value of, by states, 289 .

Riparian rights, 171, 
Roads. See Highways.

Rougbage, defined, 7 .

Rural law, 153.

Rye, digestible nutrients in, 131; fertility in, 138; value of, by states, 288; value of New York product, 282.

Rye bran, digestible nutrients in, 133 ; fertility in, 138.

Sheep, feeding standards for, 123; fleeces, number and weight of, 285 ; killed by dogs, 171; number and value of, on farms and ranges, 271; number of, not on farms or ranges, 259; number per 100,000 acres, 261 ; total num. ber of, 267; ralue of New York wool product, 282 ; value of United States wool product, 283; value of wool by states, 285; value per head, 277.

Side-paths on highways, 180.

Single-entry, 35, 37, 84 .

Smith, ledger account with, 68.

Soiling feeds, digestible nutrients in, 126.

South Carolina rock, analysis of, 139.

Statute of limitations, 203.

Stone, J. L., quoted, 117.

Straw, account with, 79, 86, 87; digestible nutrients in, 128 ; fertility in, 138.

Sugar beet leaves, digestible nutrients in, 136; fertility in, 139.

Sugar beet molasses, digestible nutrients in, 136; fertility in, 139.

Sugar beet pulp, digestible nutrients in, 136; fertility in, 139.

Sugar bcets, digestible nutrients in, 127; fertility in, 138; ralue of, by states, 287.

Sweet potatoes, value of, by states, 237.

Swine, feeding standards for, 123 ; number and value of, on farms and ranges, 271; number of, not on farms and ranges, 259; number per 100,000 acres, 261 ; total number of, 267; value per head, 277.
Tankage, analysis of, 139.

Taxes, 238; collection of, 239 ; pension mouey tree from, 239 .

Teams, ledger account with, 62; Work Report of, 33,34 .

Tenant (see, also, Lease) ; must surrender premises, 166 ; right to remove crops, 167.

Texas, rank of, in agriculture, 284, 285.

Time book. See Work Report.

Timothy hay, digestible nutrients in, 128; fertility in, 138 .

Title, abstracts of, 159 .

Tobacco, value of, by states, 290 ; value of New York product, 282; value of United States product, 283.

Tobacco stems, analysis of, 139 .

Tool account explained, 52 .

Tools, ledger account with, 62 .

Travel. See Highways.

Treasury notes. 221.

Trees along highways, 174, 181; along line fences, 187.

Trespass, by animals, 170, 186, 188, 189 , 190; by hunting, 170 ; by tenant, 166 ; on water, 153.

Trial balance, 55,70 .

Turnips, digestible nutrients in, 128; fertility in, 139.

Usury, 237.

Vegetables, value of, by states, 287 ; value of United States product, 283.

Verbal contracts, 196.

Wagering, 202.

Warranty of an animal, 205.

Warranty deed, 156, 239 .

Water, amount of, in feeds, 138; amount of, in fertilizers, 139; diversion from channel, 172; drainage, 173 ; in food materials, 118; in animals, 117; pollution of, 172 ; trespass on, 153.

Water rights, 171.

Wateringt-roughs on highwass, 181.

Weeds along highways, 182.

Weighing hay, noose for, 110; milk, 101, 104, 107; retions for cows, 102, 105, 108, 110. 
Wheat, accounts with, 26, 34; digestible nutrients in, 131 ; fertility in, 138; loss in holding, 77; value of, by states, 288 ; value of New York product, 282; ralue of United States product, 283.

Wheat bran, digestible nutrients in, 132; fertility in, 138.

Wheat fleld, account with, 86 ; ledger account with, 66 .

Wheat flour, digestible nutrients in, 131; fertility in, 138.

Wheat middlings, digestible nutrients in, 132; fertility in, 138.

Wheat straw, digestible nutrients in, 130; fertility in, 138.
Wills, 231; abstracts of, 161; advance payment to children, 236 ; how to make, 232 ; of real property, 235; who may make, 231. Wisconsin feeding standard, 123. Wolff's standard, 123, 140.

Woman, married, contracts of, 199. Wool. See Sheep.

Workman. See Employee, also Lien.

Work report, estimated wages, 83 , 144, 145; greenhouse, 91 ; method of keeping, 30,38 ; of teams, 33 , 34 ; posting accounts from, 38 , 57; posting to ledger, 38 ; sample, $40,85$. 


\section{CYCLOPEDIA OF AMERICAN HORTICULTURE}

By L. H. BAILEY

Of Coraell University, assisted by WILHELM MILLER, and many Expert Cultivators and Botenists

FOUR VOLUMES-OVER 2800 ORIGINAL ENGRAVINGS - CLOTH - OCTAVO-\$20 NET PER SET - HALF MOROCCO, \$32 NET PER SET

This great work comprises directions for the cultivation of horticultural crops and original descriptions of all the species of fruits, vegetables, flowers and ornamental plants known to be in the market in the United States and Canada. "It has the unique distinction of presenting for the first time, in a carefully arranged and perfectly accessible form, the best knowledge of the best specialists in America upon gardening, fruit-growing, vegetable culture, forestry, and the like, as well as exact botanical information. . . The contributors are eminent cultivators or specialists, and the arrangement is very systematic, clear and convenient for ready reference."

"Wo have here a work which every ambltions gardener will wish to place on hls shelf beside his Nicholson and hls Loudon, and for sueh nsers of it a too adranced nomenclature would have been confusing to the last degree. With the safe names here given there is little liabllity to serious perplexity. Thero is a growing impatience with much of the controversy concerning revision of names of prganisms, whether of plants or anlmals. Those lnvestigators who sre busied with the ecological aspects of organisms, and also those who are chiefly concerned with the application of plants to the arts of agriculture, horticulture, and so on. care for the names of organisms under examination only so far as these ald in recognition and identifiestion. To introduce nnnecessary confusion is a serious hlunder. Professor Bailey has avolded the risk of confusion. In short, In range. treatment and editing, the Cyclopedia appesrs to be emphatically usefnl: ... work worthy of rankling by the side of the Century Dletionary."-The Nation.

This work is sold only by subscription, and terms and further information may bo had of the publishers.

\section{THE MACMILLAN COMPANY}




\section{BOOKS ON AGRICULTURE}

On Selection of Land, etc.

Thomas F. Hunt's How to Choose a Farm . . . . 8176 not

E. W. Hilgard's Soils : Their Formation, and Rela-

tions to Climate and Plant Growth ..... 400 not

Isaac P. Roberts' The Farmstead ........ 150 net

On Tillage, Crops, etc.

F. H. King's The Soil . . . . . . . . 150 net

Isaac P. Roberts' The Fertility of the Land . . . 150 net

Elwood Mead's Irrigation Institutions ....... 125 net

F. H. King's Irrigation and Drainage ....... 150 net

Wm. E. Smythe's The Conquest of Arid America . . 150 net

Edward B. Voorhees' Fertilizers . . . . . . . . 125 net

Edward B. Voorhees' Forage Crops ....... . I 50 net

H. Snyder's Chemistry of Plant and Animal Life . . I 25 net

H. Snyder's Soils and Fertilizers. Third edition . . . 125 net

L. H. Bailey's Principles of Agriculture . . . . . $125 \mathrm{ne}^{4}$

W. C. Welborn's Elements of Agriculture, Southern and Western.............. 75 net

J. F. Duggar's Agriculture for Southern Schools . . 75 net

On Plant Diseases, etc.

George Massee's Plant Diseases . . . . . . 160 net J. G. Lipman's Bacteria in Relation to Country Life . 150 net E. C. Lodeman's The Spraying of Plants . . . . 125 net H. M. Ward's Disease in Plants (English) .... 160 net A. S. Packard's A Text-book on Entomology ... . 450 net

On Production of New Plants

L. H. Bailey's Plant-Breeding . . . . . . 125 net

L. H. Bailey's The Survival of the Unlike . . . . 200 net

L. H. Bailey's The Evolution of our Native Fruits . 200 net

W. S. Harwood's New Creations in Plant Life . . . 175 net

On Garden Making

L. H. Bailey's Practical Garden-Book ...... 100 not

L. H Bailey's Garden-Making ........ 150 nat

L. H. Bailey's Vegetable-Gardering . . . . . 150 net

L. H. Bailey's Horticulturist's Rule Book . . . . 75 not

I. H. Bailey's Forcing-Book .......... 125 not

A. French's Book of Vegetables ......... 175 nat 
BOOKS ON AGRICULTURE, continued

De Eratt-growing, etc.

L. H. Bailey's Nurserg-Book ......... \$1 50 not

L. H. Bailey's Fruit-growing ......... 150 nst

L. H. Bailey's The Pruning-Book ....... 150 nat

F. W. Card's Bush Fruits .......... 160

On the Care of Live Stock

Nelson S. Mayo's The Diseases of Animals . . . 180 net W. H. Jordan's The Feeding of Animals ...... 150 not I. P. Roberts' The Horse . . . . . . . . . 125 nol

George C. Watson's Farm Poultry ........ 150 not

On Datry Work

Henry H. Wing's Milk and Its Products .. . . . 180 not C. M. Aikman's Milk . . . . . . . . . . 125 not Harry Snyder's Dairy Chemistry ........ 100 not

W. D. Frost's Laboratory Guide in Elementary Bacteriology .............. 160 not I. P. Sheldon's The Farm and the Dairy. . . . . 100 net On Economics and Organization

L. H. Bailey's The State and the Farmer . . . . 125 net Henry C. Taylor's Agricultural Economics . . . . 125 net I. P. Roberts' The Farmer's Business Handbook . . 125 net Goorge T. Fairchild's Rural Wealth and Welfare. . 125 not 8. E. Sparling's Business Organization...... 125 net In the Citizen's Library. Includes a chapter on Farming.

Kate V. St. Maur's A Self-Supporting Home ... 175 not Kate V. St. Maur's The Earth's Bounty ...... 175 not

On Everything Agricultural

L. H. Bailey's Cyclopedia of American Agriculture:

Vol. 1. Farms, Climates, and Boils.

Vol. II. Farm Crops.

Vol. III. Farm Animals.

Vol. IV. The Farm and the Community.

Price of sets: Cloth, $\$ 20$ net; half-morocco, $\$ 32$ net.

For further information as to any of the above, address the publishers

THE MACMILLAN COMPANY 


\title{
L.ESSONS WITH PLANTS
}

Suggestions for Seeing and Interpreting Some of the Common Forms of Vegetation

\author{
By L. H. BAILEY \\ With dellnestlons from nature by $\mathbf{W}$. S. HOLDSWORTH, of the \\ Agricultural College of Michigan \\ SRVENTH EDITION-491 PAGES-446 ILLUSTRATIONS-12MO- \\ CLOTE-\$1.10 NET
}

There are two ways of looking at nature. The old way, which you have found so unsatisfactory, was to classify everything-to consider leaves, roots, and whole plants as formal herbarium specimens, forgetting that each had its own story of growth and development, struggle and success, to tell. Nothing stifles a natural love for plants more effectnally than that old way.

The new way is to watch the life of every growing thing, to look upon each plant as a living creature, whose life is a story as fascinating as the story of any favorite hero. "Lessons with Plants" is a book of stories, or rather, a book of plays, for we can see each chapter acted out if we take the trouble to look at the actors.

"I have spent some tlme ln most dellghtful examlnatlon of It, and the longer I look, the better I like it. I find it not only full of interest, but omlnently sug. gestive. I know of no book which begine to do so mnch to open the eyes of the stadent-whether pupil or teacher - to the wealth of mesning contsined in simple plant forms. Above all else, it seems to be full of suggestions that holp one to learn the langusge of plants, so they may talk to him."-DARWIN L. BARDWELL, Superintendent of Schools, Binghamton.

"It is an admirable book, and cannot fail both to awaken interent in the sub. jeot, and to servo as a helpful sud rellable gulde to yoing students of plant lifo. It will, I thlnk, fill sn lmportant place in eccondary schoola, and eomes at an opportune time. when helps of thls kind are needed and esgerly songht."-Professor V. M. SPALDiNG, University of Michigan.

\section{FIRST LESSONS WITH PLANTS}

An Abridgement of the above 117 PAGES-116 ILLUSTRATIONS-40 CENTS IBT

\section{THE MACMILLAN COMPANY}





